\title{
Taxonomy of the reticulate beetles of the subfamily Cupedinae (Coleoptera: Archostemata), with a review of the historical development
}

\author{
A.G. Kirejtshuk ${ }^{1,2}$, A. Nel${ }^{2}$, P.A. Kirejtshuk ${ }^{3}$ \\ ${ }^{I}$ Zoological Institute of the Russian Academy of Sciences, Universitetskaya emb. 1, St. Petersburg, \\ 199034,Russia.E-mail:agk@mail.ru,Kirejtshuk@gmail.com \\ ${ }^{2}$ Institut de Systématique, Évolution, Biodiversité, ISYEB - UMR 7205 - CNRS, MNHN, UPMC, \\ EPHE, Muséum national d'Histoire naturelle, Sorbonne Universités, 57 rue Cuvier, CP 50, \\ Entomologie, F-75005, Paris, France.E-mail: anel@mnhn.fr \\ ${ }^{3} 6^{\text {th }}$ Linia, 49-34, St. Petersburg, 199004, Russia. E-mail: polly.k@mail.ru
}

ABSTRACT:The paper is mainly devoted to the studies of the fossil Cupedidae from the Paleocene of Menat (Puy-de-Dôme, France) and to a preliminary generic analysis of the subfamily Cupedinae. All modern and fossil taxa of genus rank which could belong to Cupedinae are revised. The previous division of this subfamily into tribes (including Priacmini and Mesocupidini) is regarded as not advisable. An annotated list of the fossil species of the subfamily Cupedinae is compiled and revised. New keys to subfamilies of Cupedidae and to genera and subgenera of Cupedinae, and also keys for species of Cainomerga subgen.n. and Cupes found in deposits from Menat are given. As a result, several new genera and subgenera are proposed, i.e. the fossil Apriacma gen.n., from the early Cretaceous (the type species: Priacma tuberculosa Tan, Ren et Shin, 2006), Cretomerga gen.n., from the early Cretaceous (the type species: Priacmopsis subtilis Tan et Ren, 2006), Cupopsis gen.n. from the late Cretaceous (the type species: Paracupes svetkoi Lubkin, 2003), Cainomerga subgen.n., from the Paleocene (the type species: Mesocupes (Cainomerga) brevicornis sp.n.), Menatops gen.n., from the Paleocene (the type species: Cupes orbiculatus Kirejtshuk, Nel et Collomb, 2010), Taxopsis gen.n., from the late Eocene (the type species: Cupes motschulskyi Kirejtshuk, 2005), Cainocups gen.n., from the latest Oligocene (the type species: Cainocups aixensis sp.n.), as well as the Recent Paracupoides subgen.n., from central Ecuador, South America (the type species: Paracupes ascius Neboiss, 1989). The following species are described from the Paleocene deposits of Menat: Mesocupes (Cainomerga) brevicornis sp.n., M. (C.) fraternus sp.n., M. (C.) palaeocenicus sp.n., M. (C.) ponti sp.n., Menatops bartenevi sp.n., Cupes distinctissimus sp.n., $C$. simillimus sp.n., or commented: Menatops orbiculatus (Kirejtshuk, Nel et Collomb, 2010), comb.n. transferred from Cupes], and Mesocupes (Cainomerga) immaculatus (Piton, 1940), comb.n. transferred from Zonabris (Meloidae). Besides, some cupedine fossils from Menat remain without both description and generic attribution. Kirghizocupes Ponomarenko, 1966 is transferred from the Triadocupedinae to Cupedinae and synonymized with Mesocupoides Ponomarenko, 1969, syn.n., Pulchicupes Ren, 1995 is transfered from the Taldycupedidae to Cupedinae and provisionally synonymized with Latocupes Tan et Ren, 2006, in which also three species described in "Mesocupes" are transfered: L. angustilabialis (Tan, Huang et Ren, 2007), comb.n., L. collaris (Tan, Huang et Ren, 2007), comb.n. and L. latilabialis (Tan, Huang et Ren, 2007), comb.n. The genus Mesocupes is divided into the subgenera Mesocupes s.str., Anaglyphites Ponomarenko, 1964, stat.n., and Cainomerga subgen.n., with Priacmopsis minimus Ponomarenko, 1997 transferred to the first subgenus [Mesocupes (Mesocupes) minimus, comb.n.]. The genus Apriacma gen.n. is proposed for four fossil species previously described in "Priacma": A. clavata (Tan, Ren et Shih, 2006), comb.n., (?) A. latidentata (Tan, Ren et Shih, 2006), comb.n., P. renaria 
(Tan, Ren et Shih, 2006), comb.n., and A. tuberculosa (Tan, Ren et Shih, 2006), comb.n., while the remaining fossils species described in "Priacma" are left without generic allocation: "Priacma" corrupta Ponomarenko, 1986, "P." longicapitis Ponomarenko, 1997, "P." oculata Ponomarenko, 1997, "P." striata Ponomarenko, 2000, and "P." sanzii Soriano et Delclós 2006. The genera Asimma Ponomarenko, 1966, and Pterocupes Ponomarenko, 1966 are transferred from the subfamily Triadocupedinae to Cupedinae, albeit excluding Pterocupes leptocerus Ponomarenko, 1966, which needs revision to clarify its generic attribution. The genus Ensicupes Hong, 1976 is transferred from the family Taldicupedidae to Cupedidae and provisionally assigned to the subfamily Cupedinae. The genera Helopides Roemer, 1876, Longaevicupes Ren, 1995, Lupicupes Ren, 1995, Mesothoris Tillyard, 1916, Nannocurculionites Handlirsch, 1906, Parabuprestites Handlirsch, 1906, Paracurculionites Handlirsch, 1906, and Pseudosilphites Zeuner, 1930 are also regarded as members of Cupedidae without subfamily allocations. The positions of Anthocoleus Hong, 1983, Argentinocupes Martins-Neto et Gallego in Martins-Neto et al., 2006a, Bothynophora Heer, 1865, Celocoleus Hong, 1983, Chengdecupes Hong 1983, Cupedites Ponomarenko, 1985, Doggeriopsis Handlirsch, 1906, Euteticoleus Hong, 1983, Gansucupes Hong, 1982, Hebeicoleus Hong, 1992, Hebeicupes Zhang, 1986, Ironicus Handlirsch, 1906, Katapontisus Handlirsch, 1906, Kelidus Handlirsch, 1906, Liassocupes Zeuner, 1962, Mesotricupes Hong, 1982, Metacupes Gardiner, 1961, Paradoggeria Handlirsch, 1906, Petalocupes Hong, 1982, Stigmenamma Handlirsch, 1906, Synodus Hong, 1982, Tentyridium Westwood, 1854, and Tetrocupes Hong 1983 are also reconsidered. Both genera Clathrocupes Hong, 1980, originally described in the Taldycupedidae, and Eumecoleus Haupt, 1950, described in Oedemeridae, are regarded as archostematan genera without family assignment, although the latter seems to belong to cupedids. The genus Lecanopteryx Haupt, 1950 is regarded as a beetle without subordinal placement. The species taxon "punctomarginum Dunstan, 1923" is transferred from the genus Elaterium Westwood, 1854 to Mesothoris [Mesothoris punctomarginum (Dunstan, 1923), comb.n.]. The taxa Adinolepis Neboiss, 1984 and Ascioplaga Neboiss, 1984 are considered as subgenera of the one genus (Adinolepis). The position of the genus Priacma is discussed in special detail. It is characterized by a peculiar (Priacma-type) aedeagus which is unique among the modern Archostemata, but also shared some similarity with the Middle Jurassic genus Gracilicupes Tan, Ren et Shin, 2006. Some of its structures ("volsellar plate", "digitus volsellaris" and "cuspis volsellaris", after Edwards, 1953) are known in the structure of the male genitalia of numerous hymenopterans, but not in other holometabolans, including almost all modern representatives of the order Coleoptera. However, many archostematans and some polyphagans of different groups show probable derivatives of these structures which are traceable and can be used for phylogenetic reconstructions. The apomorphies of the order Coleoptera in general, suborder Archostemata, family Cupedidae and its subfamilies are reviewed. The problem of origin of the order is discussed, overviews of the historical development of the suborder Archostemata and subfamily Cupedinae are given. The following scheme of divergences of the order Coleoptera is proposed: Tshekardocoleidea $+\{$ Schizophorimorpha + [Cupedinae + (Ommatinae + other families of Cupedomorpha)]\}.

How to cite this article: Kirejtshuk A.G., Nel A., Kirejtshuk P.A. 2016. Taxonomy of the reticulate beetles of the subfamily Cupedinae (Coleoptera, Archostemata), with a review of the historical development // Invert. Zool. Vol.13. No.2. P.61-190. doi: 10.15298/ invertzool.13.2.01

KEY WORDS: fossil and recent Archostemata, Cupedidae, Cupedinae, classification, phylogeny, new genera and species, synonymies, fossil record, historical development. 


\title{
Таксономия лакомок подсемейства Cupedinae (Coleoptera: Archostemata), с обзором исторического развития
}

\author{
А.Г.Кирейчук ${ }^{1,2}$, А. Нель ${ }^{2}$, П.А. Кирейчук ${ }^{3}$
}

\author{
${ }^{1}$ Зоологический институт РАН, Университетская наб. 1, Санкт-Петербург, 199034, Рос- \\ cuя. E-mail: agk@mail.ru, Kirejtshuk@gmail.com \\ ${ }^{2}$ Институт систематики, эволюиии и биоразнообразия, ISYEB - UMR 7205 - CNRS, MNHN, \\ UPMC, ЕРНЕ, Национальный музей естественной истории, Университеты Сорбоны, ул. \\ Кювье, 57, СР 50, Энтомология, F-75005, Париж, Франция. E-mail: anel@mnhn.fr \\ ${ }_{3}^{3}$ 6-я линия, 49-34, Санкт-Петербург, 199004, Россия. E-mail: polly.k@mail.ru
}

РЕЗЮМЕ: Настоящая работа посвящена преимущественно изучению ископаемых купедид (Cupedidae) из палеоценового захоронения Мена (Пюи-де-Ром, Франция) и предварительному анализу родов подсемейства Cupedinae. Bce современные и вымершие таксоны, которые могли относиться к Cupedinae, ревизованы. Предшествующее деление подсемейства на трибы (включая Priacmini и Mesocupidini) рассматривается как нецелесообразное. Составлен и ревизован аннотированный список ископаемых видов подсемйства Cupedinae. Приводится новые определительные таблицы для подсемейств Cupedidae, а также для родов и подродов Cupedinae, а также определительные таблицы для видов Cainomerga subgen.n. и Cupes, найденныех в захоронении Мена. В результате предложено несколько новых родов и подродов, а именно: вымершие Apriacma gen.n. из раннего мела (типовой вид: Priacma tuberculosa Tan, Ren et Shin, 2006), Cretomerga gen.n. из раннего мела (типовой вид: Priacmopsis subtilis Tan et Ren, 2006), Cupopsis gen.n. из позднего мела (типовой вид: Paracupes svetkoi Lubkin, 2003), Cainomerga subgen.n. из палеоцена [типовой вид: Mesocupes (Cainomerga) brevicornis sp.n.], Menatops gen.n. из палеоцена (типовой вид: Cupes orbiculatus Kirejtshuk, Nel et Collomb, 2010), Taxopsis gen.n. из верхнего эоцена (типовой вид: Cupes motschulskyi Kirejtshuk, 2005), Cainocups gen.n. из позднего олигоцена (типовой вид: Cainocups aixensis sp.n.), а также современный Paracupoides subgen.n. из Центрального Эквадора Южной Америки (типовой вид: Paracupes ascius Neboiss, 1989). Из палеоценового захоронения Мена описаны следующие виды: Mesocupes (Cainomerga) brevicornis sp.n., M. (C.) fraternus sp.n., M. (C.) palaeocenicus sp.n., M. (C.) ponti sp.n., Menatops bartenevi sp.n., Cupes distinctissimus sp.n., C. simillimus sp.n., а также рассмотрены: Menatops orbiculatus (Kirejtshuk, Nel et Collomb, 2010), comb.n. перенесенный из рода Cupes, и Mesocupes (Cainomerga) immaculatus (Piton, 1940), comb.n., перенесенный из Zonabris (Meloidae). Вместе с тем некоторые остатки купедин остались неописанными и без определения родовой принадлежности. Род Kirghizocupes Ponomarenko, 1966 перенесен из Triadocupedinae в Cupedinaе и синонимизирован с Mesocupoides Ponomarenko, 1969, syn.n., Pulchicupes Ren, 1995 перенесен из Taldycupedidae в Cupedinae и предварительно синонимизирован с Latocupes Tan et Ren, 2006, в который перенесены также виды, первоначально описанные в составе "Mesocupes": L. angustilabialis (Tan, Huang et Ren, 2007), comb.n., L. collaris (Tan, Huang et Ren, 2007), comb.n. и L. latilabialis (Tan, Huang et Ren, 2007), comb.n. Род Mesocupes разделен на три подрода: Mesocupes s.str., Anaglyphites Ponomarenko, 1964, stat.n. и Cainomerga subgen.n., с перенесением и 
Priacmopsis minimus Ponomarenko, 1997 в первый подрод (Mesocupes (Mesocupes) minimus, comb.n.). Род Apriacma gen.n. предложен для четырех видов, прежде описанных в составе "Priacma": A. clavata (Tan, Ren et Shih, 2006), comb.n., (?) A. latidentata (Tan, Ren et Shih, 2006), comb.n., A. renaria (Tan, Ren et Shih, 2006), comb.n., and P. tuberculosa (Tan, Ren et Shih, 2006), comb.n., в то время как остальные ископаемые виды, описаные в составе рода “Priacma”, остаются без родовой принадлежности: "Priacma" corrupta Ponomarenko, 1986, "P." longicapitis Ponomarenko, 1997, "P." oculata Ponomarenko, 1997, "P." striata Ponomarenko, 2000, and "P." sanzii Soriano et Delclys 2006. Роды Asimma Ponomarenko, 1966 и Pterocupes Ponomarenko, 1966 переведены из подсемейства Triadocupedinae в Cupedinae, однако исключая Pterocupes leptocerus Ponomarenko, 1966, который нуждается в переизучении для выяснения родовой принадлежности. Род Ensicupes Hong, 1976 переведен из семейства Taldicupedidae в Cupedidaе и предварительно отнесен к подсемейству Cupedinae. Роды Helopides Roemer, 1876, Longaevicupes Ren, 1995, Lupicupes Ren, 1995, Mesothoris Tillyard, 1916, Nannocurculionites Handlirsch, 1906, Parabuprestites Handlirsch, 1906, Paracurculionites Handlirsch, 1906 и Pseudosilphites Zeuner, 1930 также рассматриваются в составе Cupedidae, но без отнесения к какому-либо подсемейству. Положение Anthocoleus Hong, 1983, Argentinocupes Martins-Neto et Gallego in Martins-Neto et al., 2006a, Bothynophora Heer, 1865, Celocoleus Hong, 1983, Chengdecupes Hong 1983, Cupedites Ponomarenko, 1985, Doggeriopsis Handlirsch, 1906, Euteticoleus Hong, 1983, Gansucupes Hong, 1982, Hebeicoleus Hong, 1992, Hebeicupes Zhang, 1986, Ironicus Handlirsch, 1906, Katapontisus Handlirsch, 1906, Kelidus Handlirsch, 1906, Liassocupes Zeuner, 1962, Mesotricupes Hong, 1982, Metacupes Gardiner, 1961, Paradoggeria Handlirsch, 1906, Petalocupes Hong, 1982, Stigmenamma Handlirsch, 1906, Synodus Hong, 1982, Tentyridium Westwood, 1854 и Tetrocupes Hong, 1983 также пересмотрено. Оба рода Clathrocupes Hong, 1980, первоначально описанный в Taldycupedidae, и Eumecoleus Haupt, 1950, описанный в Oedemeridae, рассматриваются как архостематы без семейственной принадлежности, хотя последний скорее всего относится к купедидам. Род Lecanopteryx Haupt, 1950 расстатривается как жук, но без отнесения к определенному подотряду. Видовой таксон “punctomarginum Dunstan, 1923” перенесен из рода Elaterium Westwood, 1854 в Mesothoris [Mesothoris punctomarginum (Dunstan, 1923), comb.n.]. Таксоны Adinolepis Neboiss, 1984 и Ascioplaga Neboiss, 1984 рассматриваются как подроды одного рода (Adinolepis). Подробно обсуждается положение рода Priacma. Он характеризуется особым строением эдеагуса, которое уникально среди современных архостемат, но сходный эдеагус отмечен у среднеюрского рода Gracilicupes Tan, Ren et Shin, 2006. Некоторые структуры [“volsellar plate”, “digitus volsellaris" и “cuspis volsellaris" согласно Эдварсу (Edwards, 1953)] известны в строении генителий самцов многих перепончатокрылых, но не у других голометабол, включая почти всех остальных современных представителей отряда Coleoptera. Однако многие архостематы и некоторые полифаги из различных групп обнаруживают предположительные производные этих структур, которые можно проследить и использовать для филогенетических реконструкций. Пересмотрены апоморфии отряда Coleoptera в целом, подотряда Archostemata, семейства Cupedidae и его подсемейств. Обсуждается проблема происхождения отряда. Приводятся обзоры исторического развития подотряда Archostemata и подсемейства Cupedinae. Предложена следующая схема дивергенции в отряде Coleoptera: Tshekardocoleidea $+\{$ Schizophorimorpha $+[$ Cupedinae $+($ Ommatinae + other families of Cupedomorpha $)]\}$.

Как цитировать эту статью: Kirejtshuk A.G., Nel A., Kirejtshuk P.A. 2016. Taxonomy of the reticulate beetles of the subfamily Cupedinae (Coleoptera, Archostemata), with a review 
of the historical development // Invert. Zool. Vol.13. No.2. P.61-190. doi: 10.15298/ invertzool.13.2.01

КЛЮЧЕВЫЕ СЛОВА: современные и вымершие Archostemata, Cupedidae, Cupedinae, классификация, филогения, новые роды и виды, синонимия, палеонтологическая летопись, историческое развитие.

\section{Contents}

Introduction 65

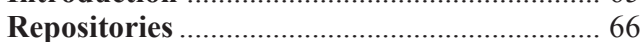

Materials and methods ………..................... 66

Abbreviations for elytral veins ......................... 67

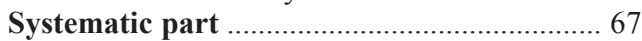

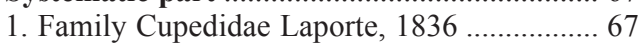

2. Key to the subfamilies of Cupedidae ............ 71

3. Subfamily Cupedinae Laporte, 1836 ............. 72

4. Key to fossil and recent genera and subgenera of Cupedinae ................................ 74

5. Subfamily Cupedinae from Menat ................. 78

5.1. Geological setting and locality information ................................................. 78

5.2. Genus Mesocupes Martynov, 1926 ........ 78

5.3. Key to species of Cainomerga subgen.n. from Menat ....

5.4. (?) Mesocupes (Cainomerga) spp. ........... 99

5.5. Menatops gen.n. .................................... 100

5.6. Genus Cupes Fabricius, 1801 ................ 103

5.7. Key to species of the genus Cupes from Menat.

5.8. Genus incertus sp.1 ................................ 114

5.9. Genus incertus sp. 2 …............................ 114

5.10. Genus incertus sp. 3 .............................. 114

5.11. Genus incertus sp.4 …………............. 115

6. New genera and species of the subfamily

Cupedinae

6.1. Apriacma gen.n. ....................................... 115

6.2. Cretomerga gen.n................................... 119

6.3. Cupopsis gen.n. .................................... 122

6.4. Genus Paracupes. Paracupoides subgen.n.

6.5. Taxopsis gen.n. ....................................... 128

7. Subfamily incertae sedis ............................... 129

7.1. Cainocups gen.n.................................... 129

8. Lists of fossil taxa re-examined .................... 130

8.1. List of fossil genera and subgenera of Cupedinae

8.2. List of fossil cupedine genera incertae sedis (with indefinite position) ............... 139

8.3. List of fossil species of Cupedinae without generic attribution.... . List of fossil cupedid genera incertae sedis (uncertain or corrected subfamily), not Cupedinae or doubtful members of Archostemata 144
8.5. List of fossil species without generic attribution from Cupedidae. 151

9. Position of the genus Priacma LeConte, 1861

10. Taxonomic rank of Adinolepis Neboiss, 1984 and Ascioplaga Neboiss, 1984 ........ 165

Discussion .................................................... 165

Historical overview of studies on Archostemata 165

Phylogeny and historical development of the suborder Archostemata ........................... 169

Phylogeny and historical development of the subfamily Cupedinae ................................. 173

Conclusions .................................................... 179

Acknowledgements ............................................ 180

References ..................................................... 181

Appendix 1. Materials studied ....................... 187

\section{Introduction}

The suborder Archostemata, the oldest group of living Coleoptera, might have appeared before the Permian (Kirejtshuk et al., 2013). It is currently considered as the sole subgroup of this order which occurred in the Palaeozoic. Reticulate beetles were quite numerous during the first half of the Mesozoic (Ponomarenko, 2003, 2013). Since the Palaeozoic to Mesozoic boundary, members of the other suborders, Polyphaga and Adephaga, appeared (Volkov, 2012) and became even more diverse. Their proportions in the late Mesozoic and Cenozoic deposits increased progressively while archostematans gradually grew less numerous and less diverse (Kirejtshuk, Ponomarenko, 2016). In the Cenozoic outcrops, archostematans are represented by few specimens and species while many Palaeozoic groups of this suborder disappeared completely. However, this ancient group is still comparatively well represented in some Cenozoic palaeobiotas. This is the case for the Eocene Baltic amber, as well as for some outcrops with compression deposits (Menat, Middle Pale- 
ocene; Messel, Middle Eocene; Eckfeld, Middle Eocene; Bembridge Marls, Eocene/Oligocene; and Pochlovice, Middle Miocene). Few Archostemata are also recorded from Aix-enProvence (latest Oligocene), Oise amber (earliest Eocene), Dominican amber (early Miocene), and Chiapas amber (Oligocene/Miocene) (Iablokoff-Khnzorian, 1960; Ponomarenko, 1973; Gersdorf, 1976; Tröster, 1993; Kirejtshuk, 2005, 2016; Perkovsky, 2007; Kirejtshuk et al., 2010; in press; etc.). All Cenozoic archostematan fossils belong to the cupedid subfamilies Cupedinae Laporte, 1836 and Ommatinae Sharp et Muir, 1912, as well as to the family Micromalthidae Barber, 1913. In the Recent fauna, this suborder is represented by few species in four families: Cupedidae, Jurodidae Ponomarenko, 1985, Micromalthidae, and Crowsoniellidae Iablokoff-Khnzorian, 1983, sporadically scattered all over the areas with nemoral and subtropical climates.

The family Cupedidae has always been regarded as keystone for understanding the evolution of the order Coleoptera in general. A very important step forward was the monograph on the historical development of the suborder Archostemata, by Ponomarenko (1969). Many new important data on the evolution of the family have since been obtained, but most of the phylogenetic hypotheses published during the last few decades are mainly based on information derived from modern members of Cupedidae (e.g. Vulcano, Pereira, 1975; Neboiss, 1984; Hörnschemeyer, 2009; etc.). The close Recent relatives of Cupes Fabricius, 1801 are only seldom included in the family Cupedidae, but rather considered separately in Ommatidae (the modern genera Omma Newman, 1839, and Tetraphalerus Waterhouse, 1901), without taking into account that the Mesozoic relatives of both Omma and Cupes showed rather mosaic distributions of the structural features which are now present only in one or another group (see discussion below). Studying the cupedine material from the Paleocene of Menat, the authors of this paper came to the conclusion that some of the examined specimens are more similar to Mesozoic relatives while others are quite char- acteristic of Recent archostematan genera and also present in the early Mesozoic. To trace the relations between these insects, the authors felt obliged to undertake a preliminary revision of the subfamily which, in turn, provided an opportunity to propose an essay on the historical development of the subfamily.

After the paper had been submitted for publication, some additional important materials were revealed and some useful recommendations were obtained. This forced the authors to introduce certain corrections to the composition of the manuscript and also to add some new parts. As a result, most illustrations remain numbered in the initial order, some more plates being added to the end.

\section{Repositories}

BMNH - Natural History Museum in London (former British Museum of Natural History)

CNU - Capital Normal University, Bejing, China

CUPC - Cornell University Paleobotanical Collection, Ithaca, USA

DEIM - Deutsches Entomologisches Institut, Müncheberg, Germany

GPIM - Geologisch-Palaeontologisches Institut und Museum, Universität Hamburg, Germany

GZUG - Geowissenschaftlishes Zentrum, Universität Göttingen, Germany

LNNR - Naturhistorisches Museum, Landessammlung für NatuLandessammlung für Naturkunde Rheinland-Pfalz, Mainz, Germany

MNHN - Muséum National d'Histoire Naturelle, Paris, France

MTM - Menat Town Museum, Puy-de-Dôme, France

PIN - Palaeontological Institute of Russian Academy of Sciences, Moscow, Russia

SFNFM - Senckenberg Forschungsinstitut und Naturmuseum Forschungsstation Grube Messel, Germany

ZIN - Zoological Institute of Russian Academy of Sciences, St. Petersburg, Russia

\section{Material and methods}

Besides the material from Menat, deposited in MNHN and in the Menat Town Museum (Village of Menat, Puy-de-Dôme), the authors 
studied many other archostematans from the Cenozoic stored in various collections, including fossil cupedids from Eckfeld (Middle Eocene), Messel (Middle Eocene), Baltic amber (late Eocene), Oise amber (earliest Eocene), Aix-en-Provence (latest Oligocene), Bembridge (Eocene to Oligocene boundary), as well as Mesozoic archostematans from BMNH, CNU, MNHN, PIN, and Staatliches Museum für Naturkunde in Stuttgart. Comparisons with Recent species were based on specimens from BMNH, MNHN, and ZIN. The species examined by the authors during the preparation of this paper are referred to in the descriptions and in the species list below (see Appendix 1). The holotypes of all new species here described are deposited in the collection of MNHN and the holotypes described in Kirejtshuk et al. (2010) in the collection of MTM.

The specimens were studied using an Olympus SCX9 stereomicroscope with an Olympus camera and a Nikon SMZ1500 with Microscope Eyepiece Camera 9.0MP Aptina Color CMOS MU900, at MNHN; a Leica MZ 12.0 stereomicroscope with a DFC290 camera, at ZIN; a Leica MZ 9.0 stereomicroscope with a DFC290 camera, at PIN; a Leica MZ 12.5 stereomicroscope with a Nikon Digital Camera DXM1200C, at CNU. Some specimens were also examined with a Tescan Vega LSU scanning electron microscope, at MNHN (Low Vacuum Secondary Electron TESCAN Detector, LVSTD), to test the characters not readily visible with optic equipment (punctation, margins of legs, shape of large sclerites, scales on elytra). The pictures of specimens from SFNFM and LNNR were taken by Sonja Wedmann (SFNFM) and Herbert Lutz (LNNR); those from CUPC were taken from Lubkin (2003).

\footnotetext{
Abbreviations for elytral veins

A1, A2, A3, A4 - anal veins;

$\mathrm{CuA}$ - cubitus anterior;

$\mathrm{CuP}$ - cubitus posterior;

$\mathrm{M}$ - median vein;

$\mathrm{R}$ - radial vein;

RA - anterior branch of radial vein;

$\mathrm{RP}$ - posterior branch of radial vein;

$\mathrm{Sc}$ - subcostal vein.
}

\section{Systematic part}

Order Coleoptera Linnaeus, 1758

Suborder Archostemata Kolbe, 1908

1. Family Cupedidae Laporte, 1836

Cupesidae Laporte, 1836; type genus: Cupes Fabricius, 1801;

= Brochocoleidae Hong, 1982; type genus: Brochocoleus Hong, 1982; currently considered as a tribe in the subfamily Ommatinae;

= Ommadidae Sharp et Muir, 1912; type genus: Omma Newman, 1839; currently considered as a subfamily (Ommatinae) in the family Cupedidae.

This family is well recognizable both in the modern fauna and as fossils due to the characteristic elytral structure consisting of two rows of cells between not more than five long primary veins. Their configuration is peculiar, including frequent fusions of long anal vein (A1) and $\mathrm{CuA}$ at the elytral apices, a squamose vestiture of the dorsum in most of the Recent and many fossil species, a more or less tuberculose dorsal surface of the head and pronotum, oval procoxal cavities broadly open externally, triangular metacoxae projecting medially, rather narrow and long legs. Having appeared in the fossil record in the Middle/late Triassic, the family Cupedidae is found to have occurred through the Mesozoic and Cenozoic, although Triadocupedinae Ponomarenko, 1966, spanned only during the second half of the Triassic (Kirejtshuk, Ponomarenko, 2016). There are more than 30 known species in the extant fauna distributed across many areas, but outside Europe (and the Western Palaearctics in general) mostly in South East Asia. Larvae of the extant species are known to develop in dead wood of angiosperm trees only. Adults occur on the surface of tree trunks and branches, frequently visiting flowers. A comparatively great number of Cenozoic fossils in this family indicates that this group must have strongly declined even since the Paleogene. Fossil Cupedinae s.str. have been recorded from the Miocene (Ponomarenko, 1973) and even reached the Pliocene in Europe (Gersdorf, 1976). Two ommatine genera have been found both in modern fauna and Mesozoic deposits. Tetraphalerites oligocenicus Crowson, 1962, also from the Eocene- 
Oligocene boundary (Isle of Wight, UK), is now transferred from the tribe Ommatini to Brochocoleini, previously regarded as an exclusively Mesozoic group (only up to the Cenomanian)(Ponomarenko, Kirejtshuk, in press). The authors follow the cupedid classification elaborated by Crowson (1962), Atkins (1963) and Ponomarenko (1969), further developed by Ponomarenko (1997, 2006; etc.), Kirejtshuk et al. (2010a, b) and Jarzembowski et al. (2013a, b). Some changes to the family's system were proposed by Tan and Ren (2009), as well as by Tan et al. (2012). These works were partly criticized from the nomenclatural and taxonomic viewpoints by Dubois et al. (2013). The systematic and phylogenetic proposals of those two publications (Tan, Ren, 2009; Tan et al., 2012) are here regarded as ill-founded because of many defects in interpreting some structures and in the consistency of applying taxonomic and evolutionary data. Some of the mistakes have been corrected in Kirejtshuk et al., 2010b, being further elaborated in the present paper.

\section{Notes on structural peculiarities}

The diagnostic characters used to separate the cupedids rather frequently show a mosaic distribution among members of different subfamilies, probably as a result of parallelisms in structural transformations (Kirejtshuk, 2005; Kirejtshuk et al., 2010a). The characters related to the structure of the prothorax with different positions of the procoxae make it possible to separate comparatively large groups (subfamilies). However, other characters used to discriminate genera, being scattered across all other subfamilies (sculptural peculiarities of the elytra, head, pronotum, procoxae with/without fold (plate), antennae, and the articulation of abdominal ventrites), can scarcely be used as traits of a significant evolutionary (phylogenetic) meaning because of their mosaic distribution among members of the family. Atkins (1958a) discussed a mosaic distribution of characters in different modern genera of the family, but the mosaicism in character patterns is even more expressed among the fossil Mesozoic groups.
The male genitalia of Recent and some fossil Cupedinae look rather different from those of Recent Ommatinae. Sharp \& Muir (1912), after comparative studies of this organ, came to the conclusion that these groups should be regarded as separate families. Some neontologists follow this opinion even now (Lawrence, 1999; Bouchard et al., 2011; Lawrence et al., 2011; etc.). In addition to the difference in structure of the procoxae, they (e.g. Lawrence, 1999) used as diagnostic the structure of the abdominal ventrites which can be flat or overlapping (the articulation of the abdominal ventrites abutting in Ommatinae versus tegular in Cupedinae, although the abdominal ventrites of Priacma LeConte, 1861 have abutting type - see below). This difference appears rather stable among Recent taxa, but most fossil ommatines are characterized by an overlapping articulation between the ventrites (both Notocupedini Ponomarenko, 1966, and Lithocupedini Ponomarenko, 1969), while many fossil cupedines (all Mesocupedini Ponomarenko, 1969) show a flat (simple) articulation between the ventrites, including some species of Cupes from Baltic amber (Kirejtshuk, 2005) (see also below the notes on the subfamily Cupedinae). As Moravocoleus permianus (Tshekardocoleidae Rohdendorf, 1944) demonstrates clearly overlapping abdominal ventrites, it seems appropriate to preliminarily suggest that such a type of articulation could be an apomorphy for the Archostemata and Coleoptera in general (see the below Discussion), but certainly plesiomorphic for cupedids. The abutting type in this case is to be treated as apomorphic in spite of its simple structure which is usually interpretated as initial for the beetles in general (Crowson, 1981). The flat (abutting) or overlapping (tegular) articulation of abdominal ventrites seem to have no clear regular relation with membrane between ventrites. In most Recent species of Cupes the tegular articulation is combined with more or less connate edges of ventrites which, however, makes it possible to bend the abdomen in the places of articulation while the abutting articulation of ventrites in the Recent Priacma serrata LeConte, 1861 is combined with hard fusion 
making it impossible to move the abdomen in the places of articulation more than in other abdominal portions. The Recent ommatines with the abutting articulation of abdominal ventrites frequently demonstrate the connate places of articulation strengthening by narrow thickened stripes along the posterior and anterior edges of each ventrite. If the type of articulation in some fossils can be defined, the problem of membranous connection or level of fusion of boundaries of ventrites almost in all fossils, remains unsolvable and inapplicable in diagnostics. Taking into account a similar variability of other structures of both groups ("Cupedidae" and "Ommatidae"), only the structure of the prosternum and procoxae can indeed be supposed as showing rather reliable characters for the discrimination of these groups, viz. Cupedinae have oval and slightly convex procoxae separated by a prosternal process and possessing a fold (plate) in the posterior part of the coxae oriented anteriorly and restricting the movement of the protrochanter and, frequently, profemur (Fig. 85). In contrast, Ommatinae usually show subspherical or conical procoxae without a fold in the posterior part and a free articulation between the procoxa and protrochanter; however, some species of Omma (i.e. Omma stanleyi Newman, 1839) have a clear plate on the procoxae.

The authors prefer to follow the traditional interpretation that these taxa fall together with Triadocupedinae (a group that demonstrates many structural parallelisms with both cupedines and ommatidines) into a single family, Cupedidae (see the Discussion below). Besides this, not infrequently many of the genera proposed in Cupedidae s.lato have been described following a study of individual elytra, without reliable characters to put them in any subfamily of those recognized in the present publication. Accordingly, these genera remain without subfamily assignment (see below in Chapter 8 and Kirejtshuk, Ponomarenko, 2016).

The distance between the procoxae, combined with the characters of elytral structure, seem to be sufficiently stable to propose a key to separate the subfamilies. Most species previously included in the subfamily Triadocupedi- nae were described in a paper in which one of the main diagnostic characters was the "procoxae separated by more than half of their diameter" (Ponomarenko, 1966a: 48). All of them originated from the same outcrop (Kyrgyzstan, Madygen). Later, the same author, having reviewed all archostematans, wrote that the members of Triadocupedinae had their procoxae separated by one diameter, combined with the absence of a prosternal process (Ponomarenko, 1969: 72). Some representatives included in this subfamily showed rather weakly expressed veins and some of them a very wide body with widely explanate elytral sides, whereas some others had a slender body and narrow elytral sides. The latter share many similarities with slender Cupedinae, except the somewhat elongate head and wider pronotal sides. At the same time, two taxa (viz. the Mesozoic Cretomerga subtilis comb.n. and the Cenozoic Taxopsis motschulskyi comb.n.) make the character of procoxae separation somewhat ambiguous because of their comparatively widely separated procoxae, combined with similarities in other characters to those in the typical Cupedinae. The character "presence of a prosternal process between the procoxae" used by Ponomarenko (1969) always means a more or less isolated structure when the procoxae are separated and, therefore, the use of of this kind of characters is very doubtful. Nevertheless, at this level of our knowledge it seems advisable to provisionally maintain a certain taxonomic isolation in the subfamily Triadocupedinae for the species with widely separated procoxae and widely explanate pronotal and elytral sides because they also have some peculiarities in the pattern of their venation and a rather strongly transverse head. However, it seems more reasonable to transfer the slender forms described in Triadocupedinae to the subfamily Cupedinae: Asimma Ponomarenko, 1966, Kirghizocupes Ponomarenko, 1966, Pterocupes Ponomarenko, 1966, and probably some species (considered above in Chapter 8) with a slender body described as members of the genus Platycupes Ponomarenko, 1966.

The "subvertical" laterosternites seem to be one of the probable synapomorphies of Omma- 
tinae and Cupedinae. This structural feature can be traced also in other cupedid fossils. For instance, Mesocupes (Cainomerga) brevicornis sp.n. and M. (C.) palaeocenicus sp.n. show such a condition (Figs 18-31). It is highly probable that subvertical laterosternites are congruent with steeply sloping elytral sides. These structures provide the elytra and the distal part of the body a morphofunctional integrity. Perhaps something similar occurs in different elateriformians with (sub)vertical laterosternites and steeply sloping elytral sides (Kasap, Crowson, 1975). However, Cupedinae and Ommatinae, in contrast to the other archostematans, including Tshekardocoleidae, have laterosternites held almost perpendicular to the plane of the ventrites (Kirejtshuk et al., 2013).

Quite significant structural peculiarities are present in the arrangement of the long longitudinal rows of cells more or less reaching the elytral apices, and in the pattern of fusions of primary veins on the elytra, which seem to be rather stable and thus allow grouping some of the relatives among members of different subfamilies. The most usual number of these rows can be nine or 10 . However, the elytra of some fossil representatives show 11 long longitudinal rows (the genera Triadocupes Ponomarenko, 1966, and Platycupes from Triadocupedinae; Kirghizocupes, probably also Priacmopsis Ponomarenko, 1966, and Mesocupes from Cupedinae; Notocupes Ponomarenko, 1964, from Ommatinae etc.). Not infrequently, in addition to the above-mentioned long longitudinal rows, there are short rows of cells which are sometimes restricted to the scutellum by a short anal vein (A2, see below), as well as a short row or confused rows along the lateral edge in the anterior part of the elytra (for example, extant species of the genera Cupes and Prolixocupes; also fossil species from different subfamilies). Cainocups aixensis sp.n. (a taxon of an obscure position in the family Cupedidae) demonstrates eight clear long longitudinal rows of larger cells in addition to four vague rows of smaller cells on the sloping sides of each elytron, along its lateral edge (see Fig. 76). Finally, a trend in forming an irregular "cellulation" on the elytra is re- vealed in many fossil Ommatinae, up to a completely diffuse and very fine "cellulation" in some species of Cionocoleus Ren, 1995 (see Jarzembowski et al., 2013a).

A generalized pattern (ground-plan) of primary veins at the elytral apices in Cupedidae seems to have included a long anal vein running along the suture and reaching the lateral edge of the elytra (as in many Cupedinae and Ommatinae), and fusion of this vein with $\mathrm{CuA}$ (as in many genera of all subfamilies and also Permocupes Martynov, 1933 and some other Permocupedidae Martynov, 1933). Ponomarenko (1969) termed this long anal vein in Cupedidae as A2, regarding that it corresponds to the anal vein which is located lateral to the prescutellar anal vein in the other archostematans, whereas A1 is missing in Coleoptera, according to that viewpoint. Thus, the prescutellar anal vein was termed as A3 while the long adsutural anal vein as A4. Such an interpretation has since become traditional (Kirejtshuk, 2005; Shcherbakov et al., 2009; etc.). Kukalová (1969) simultaneously proposed to consider this long anal line as A1, the short prescutellar anal veins as A2 (Crowson, 1981; Merkl, 1988; etc.: "scutellary striola") and the long adsutural anal vein as A3, although later she changed her initial scheme into a less adequate one without proper explanations (Kukalová-Peck, 1991). Fedorenko (2009) suggested four hypothetical anal veins for a ground-plan of the elytra in Coleoptera, yet without affirming the presence of a long adsutural anal vein. The earlier interpretations of elytral venation beginning from Comstock (1918), briefly reviewed by Crowson (1962), include the anal vein along the suture which is accompanied by a trachea and, according to Forbes (1922) and Crowson (1962), this vein is to be termed as A2. This opinion is rooted in tracheation represented by two anal tracheas. However, the short "scutellary striola" could also be interpreted as a short vein with a reduced trachea. After comparing the ancient representatives of different Palaeozoic groups of the order, Kirejtshuk et al. (2013) came to the conclusion that it appears impossible to trace back the anal vein considered by Ponomarenko 
as A1. Therefore, Kirejtshuk et al. (2013) termed the long anal vein as A1, the short vein ("scutellary striola") as A2 and the adsutural line as A3, while Fedorenko's hypothesis fails to find a factual support. At the same time, there are many transformations in A1 shape which sometimes could be interpreted as phyletic traces while in other cases transformations could correspond to a sequence of homoplastic changes. Very frequently, vein A1 does not reach the lateral edge of the elytra, but ends in the distal part of the elytral suture (probably in almost all Triadocupedinae, numerous Ommatinae, only the genus Prolixocupes among Cupedinae; somewhat similar transformations occur also in other archostematan families). Another usual mode of transformation is a trend to have an independent ending of the most primary veins along the lateral edge or, more correctly, fusion of them with Sc, which is not infrequently scarcely expressed. Such trends can be traced among cupedines and ommatines, although it is more characteristic of the latter group (including the Recent members of Omma and Tetraphalerus), and only rarely occurs among cupedines (the genera Mesocupes and Miocupes). The primary elytral veins of Kirghizocupes, the oldest known cupedine group, are rather weak and show no trace of fusion, but gradually become more narrowly separated by progressively smaller cells at the apices. In some cases, fusions of the primary veins follow a different pattern. For example, Cainocups aixensis sp.n. has vein A1 subrectilinearly reaching the elytral apices and apically fusing with a vein resulting from the fusion of CuA, M, and R (see Fig. 76). Finally, if the Triadocupedinae are generally characterized by weakly elevated veins, the elytra of some fossil groups show only long longitudinal rows of very large cells sometimes not very regular in shape (in the cupedine genus Mesocupes and some genera in Ommatinae, Lithocupes Ponomarenko, 1966, Brochocoleus Hong, 1982 , etc.) to completely diffuse and fine cells without a trace both of rows and veins (Cionocoleus). In some cases, all veins become subequally expressed and look like thick rollers without fusion at the apex (f.i. Anaglyphites stat.n.: Figs 95-100). Such a condition of elytral structure looks like intermediate between the one typical of the members of Cupedinae and that characteristic of the members of Taldycupedidae Rohdendorf, 1961 and some other Palaeozoic groups.

Other quite important characters demonstrating parallel transformations can be observed in structural peculiarities of the head (convexities and tuberculations on its upper surface and the position of the antennal insertions) and abdomen (type of articulations of segments), which are frequent at least among Cupedinae and Ommatinae, probably also in Triadocupedinae. These characters are considered in more detail for the subgroups of the subfamily Cupedinae (see below). A similar situation seems to be characteristic of the other subfamilies.

\section{Key to subfamilies of Cupedidae}

(based on the key proposed by Ponomarenko, 1969)

1. Elytra with long longitudinal rows of very large cells and extremely narrow interspaces between them, veins not elevated; procoxae widely separated (distance between them subequal to or greater than their diameter); elytra comparatively wider than in other subfamilies, up to very wide, usually flatly or gently sloping and widely explanate on sides, with apparently more or less wide epipleura and veins very weakly raised. ........... Triadocupedinae Ponomarenko, 1966

- Elytra with long longitudinal rows of moderately large cells and interspaces between them making it possible to observe veins; procoxae usually narrowly separated (distance between them less than their diameter) to/or conjoining; elytra frequently with more or less clear veins, their sides more or less steeply sloping (up to subvertical) and narrowly explanate; if procoxae widely separated, elytra narrow, with subvertically slopping sides and rather narrow epipleura (Cretomerga gen.n. and Taxopsis gen.n.) ........... 2

2. Procoxae more or less separated, with a flat fold oriented anteriorly and covering protrochanter and base of profemur; head mostly of usual shape with a gradually narrowing frons ..... Cupedinae Laporte, 1836

- Procoxae conjoining, often without a flat fold oriented anteriorly and covering protrochanter, sometimes conically projecting; head often somewhat elongate and frequently with a rather wide anterior part...

Ommatinae Sharp et Muir, 1912 


\section{Subfamily Cupedinae Laporte, 1836}

Type genus Cupes Fabricius, 1801

= Priacmini Crowson, 1962; type genus: Priacma LeConte, 1861; currently not considered as separate tribe;

= Mesocupedini Ponomarenko, 1969; type genus: Mesocupes Martynov, 1926; currently not considered as separate tribe.

\section{Notes on the taxonomy and systematics of Cupedinae}

This subfamily is sometimes subdivided into tribes (Crowson, 1962; Ponomarenko, 1969; Tan, Ren, 2006, 2009; etc.). However, the tribe Priacmini has been shown to be impossible to discriminate based on external structures (see below). The unique structure of the male pregenital sclerites and aedeagus in Priacma, makes this genus different from other genera of the subfamily. However, this character is not applicable for most fossils (Kirejtshuk et al., 2010). The tribe Mesocupedini has been proposed for some Mesozoic genera with flat (not overlapping) abdominal ventrites and a weakly tuberculate dorsal surface of the head. Abdominal ventrites, if they are tegular and/or showing a transverse depression along the base following Ponomarenko (1969), are frequently regarded by paleocoleopterists as an important diagnostic character for supraspecific taxa of the family. The neontologists usually do not use them, although sometimes these characters are mentioned in the species descriptions (Atkins, 1963) or recognised as diagnostic for some groups (Lawrence, 1999). This structural feature (articulation type of abdominal ventrites) could be sometimes rather efficient for grouping the species, but it is rather variable in larger groups of related species. For example, the abdominal ventrites of extant representatives are completely flat (apparently also in fossil species of Omma and Tetraphalerus) while in the extant Paracupes brasiliensis Kolbe, 1898, they have both a transverse depression at the base and a convex roller behind the middle. On the other hand, extant representatives of Priacma, Ascioplaga Neboiss, 1984, stat.n., Prolixocupes Neboiss, 1960, and Rhipsideigma Neboiss, 1984, dem- onstrate only a weak depression and a weak roller behind it (usually scarcely traced). At the same time, most recent species of Cupes have a rather raised depression and a roller on each of ventrites $2-4$. However, among specimens from a large series of modern Cupes capitatus Fabricius, 1801, or C. mucidus Chevrolat, 1829, a highly variable degree of expression of these features can be observed. Their congeners from Baltic amber also show variability from completely flat ventrites up to ventrites with a clear transverse depression (groove) (Kirejtshuk, 2005). The abdominal ventrites in compression fossils frequently show overlapping between them, although in some cases they are not clearly visible or absent. Therefore, many remains cannot be diagnosed, based on these characters of ventrites. Thus, using these features for grouping has caused some confusion in defining the tribes and subfamilies (partly considered below) and requires caution, taking into consideration the above variations.

Elytral venation and the pattern of cells (see above in the "Notes on structural peculiarities to the family Cupedidae") represent highly important characters for dividing the subfamily into groups. Many slender species can be grouped, based on the expression of the differences between primary and secondary veins, the number of veins, and the patterrn of conjunction of the primary veins, in particular, the sequence in their conjunction at the elytral apices. The most outstanding fusions are, as in Ommatinae groups, the sequential fusion of $\mathrm{CuA}$ with $\mathrm{A} 1$ and $\mathrm{M}$, sometimes a separate fusion of $\mathrm{A} 1$ and $\mathrm{CuA}$ and a fusion of $M$ to $R$. This group of structural peculiarities is somehow associated with the character of sloping of the sides (gentle or subvertical along a flat median part of the elytral disk), of the bending line and of the explanation (flattening) of the lateral submarginal stripes of the elytra. It is noteworthy that fusion of veins in species with distinct primary veins is usually quite distinct, whereas the fusions of veins in forms with weakly raised primary veins are vague or even quite variable. In cases when the elytral veins are not elevated, the fusions of veins at the apices are obscure or untraceable. 
Some forms from the Triassic (including Kirghizocupes) have the elytra with weak primary veins which look like reaching the apices without fusion.

The degree of separation of antennal insertions was used by Crowson (1962) for tribal diagnostics in the subfamily Cupedinae. Later reseachers followed him in the discrimination of Cupedini and Priacmini. Application of this character as a diagnostic group character introduced a certain confusion because Priacma serrata, has comparatively small eyes and the distance between its antennal insertions is comparable to that in other Recent Cupedinae (in Cupes mucidus and other species with comparatively larger eyes). The most important fact is that many extant (including Priacma serrata) and Cenozoic cupedines (except members of Mesocupes (e.g. Cainomerga subgen.n.) and Menatops gen.n.) show the antennal insertions rather deep at their anterior edge, close to each other and more or less covered by a strong tubercle of the frons at their posterior edge. Their scapes are also rather thick while those of many Mesozoic members of the subfamily are moderately thick to even rather thin and more widely (or moderately) separated. Finally, Mesozoic cupedines usually have completely open antennal insertions (not covered by tubercles posteriorly). This character can be redefined, taking into account that the antennal insertions of most of the extant cupedines (including Priacma serrata) are much more narrowly separated than the distance between the inner edges of the eyes on the upper surface of the epicranium. On the contrary, many Mesozoic species generally have somewhat different structures of the head, with varying shapes of the scape, and therefore they could be regarded as a set of taxa distinct from modern cupedines with comparable partial similarities to modern species of Cupes and Priacma. It is necessary to mention that the proportion of length of antennae to body length (or even the comparative length of a particular antennomere, sometimes used for group diagnostics) shows some variability as well, frequently depending on body size and sex (Kirejtshuk, personal observation). The comparative length of the entire antennae can be a reliable character only in some exceptional cases, but not in many supraspecific taxa as it has frequently been used by some paleocoleopterists.

An important feature of many cupedine groups is structure of the upper integument of the epicranium, i.e. configuration and degree of development of convexities (tubercles) on the frons and vertex. These structural peculiarities are very easy to study in the modern taxa, but often difficult to trace in compression fossils. The structure of the tubercles over the antennal insertions is particularly important if they are raised. This feature is very characteristic of modern cupedines, while many fossil members have convexities only behind the antennal insertions. In such cases, a frontal anterior depression (located in modern species just before the anterior edge of the frons, in front of the tubercles covering the antennal insertions) is shifted posteriad behind the antennal insertions. This structural change seems to have been frequently associated with some convexity at the anterior edge of the frons. Similar transformations can also be observed among ommatines and triadocupedines. In some case the median space between tubercles (longitudinal convexities) looks like a longitudinal depression and bears a more or less clear sculptural line (or sometimes a weak and narrow carina). Therefore, in many fossils the depression shifted posteriad looks like an expressed Y- or V-shaped depression which sometimes is called "epicranial suture" (Ponomarenko, 1969). This term has since been in use even without quotation marks (e.g. Tan et al., 2012; Jarzembowski, 2013a; etc.), as an equivalent to the traditional term coined for the suture on the epicranium of beetle larvae and which also concerns both larvae and adults in polyneopteran groups. Usage of this term for coleopterous adults could easily create great confusion, although rediments of epicranial suture can be traced in different coleopterous groups, including fossil and modern cupedines.

Some early Cretaceous species have been attributed to the genus "Priacma" (Ponomarenko, 1986, 1997, 2000; Soriano, Delclós, 2006), even though those remains share many charac- 
ters of a whole number of cupedine genera. However, in fact it is impossible to be certain about the generic placement of any of them. It would be more reasonable at the current level of our knowledge to regard these species of "Priacma" as Cupedinae or Cupedidae without any generic assignment (see below Chapter 8), because they fail to demonstrate any evidence of a closer relationship to Priacma serrata than some other Mesozoic cupedines do. Hieke \& Pietrzeniuk (1984) recorded the genus Priacma from Baltic amber, but that finding was not accompanied by a picture or any other piece of evidence. As a result, the genus Priacma remains monotypic. Its type species, Priacma serrata, is characterized by a unique structure of its aedeagus (Priacma-type) among extant cupedids, although species of the Mesozoic Gracilicupes Tan, Ren et Shin, 2006, and some still undescribed fossils show similar genital structures (personal communication of A.G. Ponomarenko). The difference in structure of the male genitalia cannot be used for separating most of the fossil genera because their genitalia remain unknown. Nevertheless, the male genitalia of the few fossil species from different genera known (Apriacma gen.n., Latocupes Tan et Ren, 2006, and Mesocupes Martynov, 1926) certainly look more similar to those of the Recent genera closely related to Cupes (Cupes-type) than to those of Priacma, albeit most of the other (external) characters appear to be more similar to those in Priacma serrata rather than to those of the other modern genera. Traces of an aedeagus in the holotype of Gracilicupes tenuicruralis Tan, Ren et Shih, 2006, suggest that organ to have been be at least considerably wider than in most cupedines (or cupedids) with a rather narrow penis trunk particularly at apex and with two pairs of lateral lobes, and widely and separately curved narrow parameres (Priacma-type — see detailed description below). All known male genitalia of Cupedinae, except those in Priacma serrata and Gracilicupes tenuicruralis, show a trilobed Cupes-type of the male genital structure, including a tube-like penis trunk (median lobe without lateral compression) and comparatively wide and usually subflattened parameres (lateral lobes) with narrow appendages at base and at apices. These exceptions (i.e., aedeagi of Priacma serrata and Gracilicupes tenuicruralis) demonstrate many characters occurring in other holometabolan groups which could be a symplesiomorphy for Priacma and Coleoptera as a whole (see below Chapter 9).

\section{Key to fossil and Recent genera and subgenera of Cupedinae}

(partly based on keys in Crowson, 1962; Atkins, 1963; Ponomarenko, 1969; Neboiss, 1984)

1. Frons distinctly excavate along anterior part of rather long and very large eyes, but convex medially; transverse diameter of eyes nearly as great as half the distance between rather long eyes; antennal insertions rather narrowly separated and covered by distinct tubercles on frons; lateral rows of punctures confluent in distal half of elytra; scales on elytra elongate (lanceolate) and sparse. Fossil; late Cretaceous (USA, New Jersey, Old Crossman's Clay Pit). Figs 80-83

Cupopsis gen.n.

- Frons convex or flattened along anterior part of eyes or with a Y-shaped depression in the middle or a small triangular depression between antennal insertions; transverse diameter of eyes clearly less than half the distance between eyes (only species of Menatops gen.n., Mesocupes (Cainomerga) ponti sp.n. and $M$. (Mesocupes) spinosus (Ponomarenko, 1964), comb.n. could be with transverse eye diameter subequal to distance between eyes); combination of remaining characters different

2. Pronotum about as long as wide to almost elongate, arcuate on sides, gradually narrowing both anteriorly and posteriorly, its anterior angles not projecting (as on the photograph in Fig. X, 7 (page 97) but not in drawing in Fig. 5 (page 97) in Ponomarenko, 2006); elytra with 10 regular long longitudinal rows of comparatively small suboval cells, but without clear veins; temples behind small eyes longer than anterior part of head before eyes; length of body ca. $6.5 \mathrm{~mm}$. Fossil; early Cretaceous (England, Early Purbeck) ....... Chalepocarabus Handlirsch, 1906

- Pronotum more or less transverse, variable in configuration, but not arcuate on sides, its anterior angles more or less distinctly projecting; combination of remaining characters different

3. Head with very long temples (longer than frons before eyes) and subflattened; all primary veins on elytra parallel, not fusing at apices; veins 
equally weakly raised, but well expressed and cells between them with a weak arrangement in regular rows; pronotum strongly transverse (about twice as wide as long) and subrectilinearly widening from base to distinct anterior angles; body elongate; length of body $12.5 \mathrm{~mm}$. Fossil; Miocene (Czech Republic, Pochlovice). Ponomarenko, 1973: 104, Figs a-c

Miocupes Ponomarenko, 1973

- Head with short or moderately long temples (at most as long as frons before eyes, although Cupidium abavum Ponomarenko, 1968, has rather small eyes located at a comparable distance from both anterior edge and widest point of temples); elytra with non-subparallel veins and usually fusing at apices; combination of remaining characters different . 4

4. Head with a clear Y- or V-shaped depression on frons at or behind antennal insertions, formed because of paramedian convexities behind antennal insertions .. 5

- Head without Y-shaped depression on frons, at most with a transverse emarginate depression between antennal insertions or a subtriangular/ subsemicircular depression in anterior part of frons before antennal insertions (although head of Mesocupes (Mesocupes) bidens Ponomarenko, 1964, has traces of a weak Y- or V-shaped depression; in the comparatively large Priacmopsis adumbrata Ponomarenko, 1966, the subtriangular depression on the frons is very large) 10

5. Prosternum before procoxae at most about as long as procoxae; head with neck half as wide as head at temples, without tubercles over antennal insertions; elytra with primary and secondary veins comparable in expression and with somewhat transverse, large cells arranged in nine long longitudinal rows; body more than three times as long as wide; distance between antennal insertions greater than half of the distance between eyes. 6

- Prosternum before procoxae much longer than procoxae; head with neck half as wide as head at temples and with more or less raised tubercles over antennal insertions; combination of remaining characters different .... 7

6. Procoxae narrowly separated (distance between them less than their diameter); head with antennal insertions completely open; body length ca. $9.2 \mathrm{~mm}$. Fossil; early Cretaceous (China, Liaoning). Figs 91-92....

Furcicupes Tan et Ren, 2006

- Procoxae widely separated (distance between them greater than their diameter); head with antennal insertions slightly covered with tubercles; body length ca. $11.5 \mathrm{~mm}$. Fossil; early Cretaceous
(China, Liaoning). Figs 77-79

Cretomerga gen.n.

7. Elytra with nine long longitudinal rows of cells and a very clear difference between main and secondary veins; body at least three times longer than wide; metaventrite about as wide as long; anterior angles of pronotum projecting and subacute; elytra with nine long longitudinal rows of cells; primary veins of elytra better expressed than secondary ones; elytra with disks flat and subvertically sloping along $\mathrm{M}$; pronotum about 1.5 times as wide as long and widening anteriorly; scape subequal in length and slightly thicker than antennomeres $2-11$ or 3-11; length of body ca. 9.5-16.5 mm. Fossil; early Cretaceous (China, Liaoning). Figs 73-75

Apriacma gen.n.

- Elytra at least with 10 long longitudinal rows of cells and only a slight difference between main and secondary veins; metaventrite markedly wider than long; anterior angles of pronotum not projecting and rectangular or blunt to rounded; body less than three times as long as wide (only in Latocupes elytra with 9 longitudinal rows of cells while in L. bellus comb.n. anterior angles slightly subacute); combination of remaining characters different 8

8. Antennomere 3 longest (at least twice as long as each of antennomeres 2 and 4); elytra with apparently gently sloping sides and 10 long longitudinal rows of large cells subparallel or only slightly coverging at apices; primary veins, if expressed, without fusion $\mathrm{A} 1$ and $\mathrm{CuA}$; pronotum slightly transverse (less than 1.5 times as wide as long) and with arcuate sides, its anterior and posterior angles rounded; length of body ca. 5.8-10.0 mm. Fossil; late Jurassic (Kazakhstan, Karatau), early Cretaceous (Transbaikalia, Baissa; Mongolia, Bon Tsagan). Figs 95-102 ......

(Anaglyphites Ponomarenko, 1964, stat.n.) - Antennomere 3 not longest; elytra with long longitudinal rows of cells making it possible to trace fusion of $\mathrm{A} 1$ and $\mathrm{CuA}$; combination of remaining characters different ............................ 9

9. Elytra with subvertically sloping sides and long longitudinal rows of subquadrangular, subsquare and sublongitudinal cells or at most slightly transverse, much more than twice as long as wide combined (usually about 2.5 times); pronotum slightly transverse (less than 1.5 times as wide as long) and not widening anteriorly; scape nearly as thin as following antennomeres; length of a very slender body ca. 4.0-7.5 mm. Fossil; Middle-late Triassic (Kyrgizstan, Madygen). Figs 109-116

Kirghizocupes Ponomarenko, 1966 (= Mesocupoides Ponomarenko, 1969, syn.n.) 
- Elytra with gently sloping sides and long longitudinal rows of subquadrangular and, on disks, strongly transverse cells (about twice as wide as long), about 1.5 times as long as wide combined (about twice); pronotum strongly transverse (1.52.0 times as wide as long); scape markedly thicker than following antennomeres; length of a more robust body ca. 12-27 mm. Fossil; Middle Jurassic (Inner Mongolia, Daohugou), early Cretaceous (China, Liaoning; Bejing Province, Lushangfen). Figs 117-119.

\section{Latocupes Tan et Ren, 2006}

$(?=$ Pulchicupes Ren, 1995)

10. Body length about $30 \mathrm{~mm}$; metacoxae very slightly extended in mesal part, forming a gentle curve along their posterior edge; metaventrite about twice as wide as long; head with tubercles over antennal insertions and at temples; tarsomere 4 lobed; antennomere 2 (pedicel) much shorter than antennomeres 1 (scape) and 3; long longitudinal rows on elytra with small suboval to subquadrate cells; pronotum about twice as wide as long; head somewhat tuberculate. Fossil; early Cretaceous (Transbaikalia, Baissa). Ponomarenko, 1969: 112, Fig. 61; Figs 120-121 ......

Priacmopsis Ponomarenko, 1966

- Body not longer than $20 \mathrm{~mm}$; metacoxae moderately or strongly extended in mesal part and clearly subtriangular; metaventrite markedly less than twice as wide as long; combination of remaining characters different 11

11. Head with very large eyes and much wider than pronotum with arcuate sides and nearly rounded anterior angles; prosternum before procoxae not longer than procoxae; elytra with primary and secondary veins comparable in expression and with 10 regular rows of large cells; head narrowing behind very large eyes (along temples); scape significantly thicker than following antennomeres, forming subfiliform antennae; abdominal ventrite 1 much longer than each of ventrites 2 4; body about 2.5 times as long as wide; eyes with transverse diameter as great as third of distance between eyes; femora and tibiae rather thin and long; male genitalia of Priacma-type (penis trunk with an acuminate apex, parameres very narrow and strongly curved); length of body ca. 10.8-11.4 mm. Fossil; Middle Jurassic (Inner Mongolia, Daohugou). Figs 93-94

Gracilicupes Tan, Ren et Shin, 2006

- Head more or less narrower than pronotum (head subequal to or only slightly wider than pronotum only in some Mesocupes s.lato, which have, however, smaller eyes and antennae rather submoniliform, and also in some Cupes, which have, however, an always longer prosternum, pronotal sides not arcuate, distinct anterior an- gles and more or less smaller eyes); prosternum before procoxae usually longer than procoxae (although prosternum in some species of Cainomerga subgen.n. and Mesocupes s.str. about as long as procoxae); combination of remaining characters different 12

12. Part of prosternum before procoxae shorter than procoxae; head triangular and with comparatively small eyes located at a comparable distance from both anterior edge and widest point of temples; antennomeres 1-3 with comparable lengths; pronotum about twice as wide as long, somewhat shorter than head and with arcuate sides; body length ca. $10.0 \mathrm{~mm}$. Fossil; late Jurassic (Kazakhstan, Karatau). Figs 107-108

Cupidium Ponomarenko, 1968

- Part of prosternum before procoxae longer than procoxae; combination of remaining characters different. 13

13. Elytra with nine rows of clear large cells or, if with 10 rows, $1-2$ rows at lateral edge not extending behing basal third of elytra; primary and secondary veins of elytra very contrasting in levels of development; elytral disks flat (horizontal) and sides vertically slopping along $\mathrm{M}$; antennal insertions narrowly separated; distance between them usually less than transverse diameter of moderately large eyes; prothorax usually with more or less expressed tarsal grooves .... 14

- Elytra at least with 10 rows of cells of different outlines, extending behind the middle; combination of remaining characters different; elytra with regular rows of clear larger cells reaching elytral apices or cells arranged in less clear rows or very small; primary and secondary veins of elytra similar in degree of development or, rarely, with contrasting primary veins (in Paracupoides subgen.n.); antennal insertions usually widely separated (in Paracupes s.str., Paracupoides subgen.n. and Priacma they are comparatively narrowly separated); eyes of different size; prothorax without traces of tarsal grooves 19

14. Prosternum with process about as wide as procoxae (or slightly narrower than base of epipleura) and widely rounded at apex; elytra with strongly transverse cells (about twice as wide as long); head with two pairs of paramedian tubercles (at antennal insertions and at base of eyes) and strongly projecting temples; elytra with a short anal vein isolating three cells at scutellum; length of body ca. 16.1-18.1 mm. Fossil; late Eocene (Baltic amber). Figs 121-122.

Taxopsis gen.n.

- Prosternum with process much narrower than procoxae (or at most half as wide as base of 
epipleura) and narrowly rounded to subacute at apex; elytra with cells of different shape, but never strongly transverse (only slightly wider than long); combination of remaining characters different 15

15. Al fused with $\mathrm{CuA}$ and then with $\mathrm{M}$, futher curving and ending in distal portion of the suture (not reaching lateral edges of elytra); all four upper head tubercles obtuse, posterior ones distinctly much larger and longer than anterior ones; scales on elytra suboval; tarsal grooves anteriorly separated by full width of prosternum; basal half of elytra with ten rows of punctures, the 7 th and 8th confluent and terminating before the middle; length of body 10-12 mm. Recent; Western Hemisphere species (Chile; Argentina; USA: California, Arizona). Neboiss, 1960: 20, Figs 3 ..... Prolixocupes Neboiss, 1960

- A1 fused with $\mathrm{CuA}$ and then reaching lateral edges of elytra; one or two pairs of somewhat conical head upper tubercles, the latter subequal in size; subsemicircular or laterally flattened; combination of remaining characters different ....... 16

16. Head with one pair of distinct upper paramedian conical tubercles situated above bases of antennae . 17

- Head with 2-3 pairs of upper paramedian conical tubercles, anterior pair situated above base of antennae, posterior pairs along and behind eyes . 18

17. Elytra with punctures free of scales; male abdominal tergite IX slender, distinctly constricted before a rounded base; length of body ca. 6-16 mm. Recent; Australian species. See Neboiss, 1984: 469, 470, 475; Figs 85-88, 99 \& 117 ..

Adinolepis (Adinolepis) Neboiss, 1984, s.str.

- Elytra covered with oval or elongate oval scales; male abdominal tergite IX rather broad, gradually tapered towards base, middle of apex extended into an elongate, slightly spatulate lobe; length of body ca. 9.0-14.5 mm. Recent; New Caledonian species. See Neboiss, 1984: 469 \& 476, Figs 89-90 \& 118-119 Adinolepis

(Ascioplaga Neboiss, 1984) stat.n.

18. Elytra with a dense cover of scales more or less completely covering contours of elytral cells; apices extended into an acute point; preapical conjoining of main veins; A1 conjoining with median vein at elytral apex, forming a strong elevation, while $\mathrm{CuA}$ not reaching this conjoining; length of body ca. 11.0-20.5 mm. Recent; East African (Tanzania) and Madagascar species. See Neboiss, 1984: 470 \& 476 Figs 91-94 \& 120-123 ..... Rhipsideigma Neboiss, 1984

- Elytra with scales mostly on intervals, cell outlines not obscured by scales; elytra with apices not extended into an acute point; $\mathrm{A} 1$ fused with $\mathrm{CuA}$ before subapical fusion with $\mathrm{M}$; length of body 6.0-12.5 mm. Fossil, Palaeocene (Menat), Eocene (French Oise and Baltic amber; Germany, Messel, Eckfeld), Pliocene (Germany, Willershausen, Niedersachsen); Recent; Asian(Palaearchiarctic Province (Primorsky Kray, Japan, continental China, Philippines) and Indo-Malayan Region, including the Papuan Province (Kalimantan, New Guinea)), Australian, North American (Canada, USA), Polynesian (Hawaii), South African species. Figs 41-72, 169-172

Cupes Fabricius, 1801

(=Cupoides Motschoulsky, 1856; Tenomerga

Neboiss, 1984; Distocupes Neboiss, 1984)

19. Part of abdominal ventrite 1 exposed from under metacoxae not longer than each of following ventrites 2-4; gular sutures very widely separated, with a distance between them more than $2 / 3$ as great as maximum width of head; male genitalia of Priacma-type (penis trunk with an acuminate apex, parameres very narrow and strongly curved); head with antennal insertions covered by strong tubercles; elytra with irregularly truncate apices and 10 rows of cells reaching elytral apices; elytral lateral carina thickened as a rather wide stripe with sharp tubercles; length of antennomere 2 (pedicel) less than half the length of antennomeres 1 (scape); distance between eyes more than half the distance between eyes; body rather slender, length ca. 10-17 mm. Recent; USA (West of the Rocky Mountains: California, Oregon, Washington, Idaho, Montana, British Columbia). Figs 124-134

Priacma LeConte, 1874

- Part of abdominal ventrite 1 exposed from under metacoxae markedly longer than each of following ventrites 2-4; gular sutures moderately widely to narrowly separated, with a distance between them about $1 / 3$ as great as maximum width of head or even less; male genitalia of Cupes-type (usual cupedine trilobed structure); combination of remaining characters different ............... 20

20 . Head very short and strongly transverse, with transverse diameter of eyes markedly more than half the distance between eyes; pronotum 1.52.0 times as wide as long; anterior angles of pronotum with a distinct top; primary veins more raissed than secondary ones; antennomere 2 (pedicel) about half as long as antennomere 3; length of body 7.2-9.1 mm. Fossil; Palaeocene (Menat). Figs 10-17, 165-168

Menatops gen.n.

- Head elongate and at most slightly transverse, with transverse diameter of eyes less than half the distance between eyes; pronotum much less than twice as wide as long; combination of remaining characters different 
21. Elytra obliquely truncate at apices; head with strong tubercles over antennal insertions; elytra with subvertically slopping sides, narrowly explanate along subreclilinear lateral edges. Recent; South America

Paracupes Kolbe, 1898...22

- Elytra subacute or nearly rounded at apices; head without raised tubercles over antennal insertions; elytra with gently slopping sides and more or less explanate along broadly rounded lateral edges. Fossil; Mesozoic and Cenozoic ....

Mesocupes Martynov, 1926...23

22. Elytra with slight differences between primary and secondary viens (both somewhat obliterated), a serrate apical edge and A1 subparallel to suture; elytral integument covered by narrow elongate (to elliptic) scales with truncate apices, leaving cells partly open; elytral lateral carina thickened as a rather wide stripe with sharp tubercles; pronotum widening anteriorly; anteromedian gular plate slightly longer than wide (1.2 times); length of body ca. 12-15 mm. Recent; Brazilian species. Figs 84-86

... Paracupes (Paracupes Kolbe, 1898), s.str.

- Elytra with distinct primary and weak secondary viens, a smooth apical edge and A1 clearly deviating from suture in both anterior and posterior fifths; elytral integument thoroughly (including cells) covered by subtriangular scales (widening to a truncate apex); elytral lateral carina simple; pronotum subparallel-sided; anteromedian gular plate almost twice longer than wide (1.9 times); length of body $10.4 \mathrm{~mm}$. Recent; Ecuador species. Figs 87-90

Paracupes (Paracupoides subgen.n.)

23. Cells in long longitudinal rows on elytra subquadrate or somewhat transverse; elytra about or somewhat more than twice as long as wide combined; length of body 16.3-18.5 mm. Fossil; Palaeocene (Menat). Figs 5-9, 18-40....

. Mesocupes (Cainomerga subgen.n.)

- Cells in long longitudinal rows on elytra more or less oval and sparser; elytra less than twice as long as wide combined; body length ca. 4.5-8.4 mm. Fossil; Late Jurassic (Kazakhstan, Karatau), Early Cretaceous (Spain, Las Hoyas). Figs 1-4, 103-106 Mesocupes

(Mesocupes Martynov, 1926), s.str.

\section{Subfamily Cupedinae from Menat}

\subsection{Geological setting and locality infor- mation for Menat specimens}

The Middle Paleocene Menat fossil site (Menat Basin, Puy-de-Dôme, France) is a volcanic maar containing a lake ca. $700 \mathrm{~m}$ in diameter, which at present contains sedimentary rocks (spongo-diatomites) with remains of diverse aquatic and terrestrial flora and fauna (Piton, 1940; Nel, 1989, 2008; Wappler et al., 2009; Nabozhenko, Kirejtshuk, 2013; etc.). This locality has been well known since the beginning of the 20th century (Fritel, 1903; Laurent, 1912; etc.) and a general preliminary overview of its biota was published by Piton (1940). According to Wappler et al. (2009), the plant and insect diversity in the lacustrine outcrop of Menat is comparatively high, confirming the results of Piton (1940), who was the first to describe the fossil flora and fauna. Recent field investigations made by our team strongly suggest that it is even higher than thought before. The composition of faunal and floral remains makes it possible to conclude that this lake was surrounded by a paratropical evergreen forest and the palaeoenvironment was very warm and humid, supporting a high insect diversity. Following the pollen, paleomammalian stratigraphic and radiometric $\mathrm{K} / \mathrm{Ar}$ analyses, the age of Menat was estimated at $59 \mathrm{Ma}$ (Kedves, Russel, 1982; $\mathrm{Nel}, 2008)$. However the newest estimates based on macroflora postulate its age within 60-61 Ma (Wappler et al., 2009). Interestingly, beetles dominate the animal biodiversity in terms of species number and the abundance of specimens, as they represent more than $80 \%$ of the animals collected in this outcrop (after the collection of ca. 1,200 animals made during the years 2013-2015). Nevertheless, the most abundant beetle group remains the Curculionoidea while the Archostemata are represented by 32 fossils, and part of them will be considered in a further paper.

\subsection{Genus Mesocupes Martynov, 1926}

Type species Mesocupes primitivus Martynov, 1926, by monotypy, fossil.

Composition. The genus includes 16 species from the late Mesozoic and Paleocene [see the list and comments in Chapter 8 and in the catalogue by Kirejtshuk \& Ponomarenko (2016)]. The subgenera Mesocupes s.str., Anaglyphites stat.n. and Cainomerga subgen.n. recognized in this paper can be diagnosed after the above key and, in addition, these groups have 

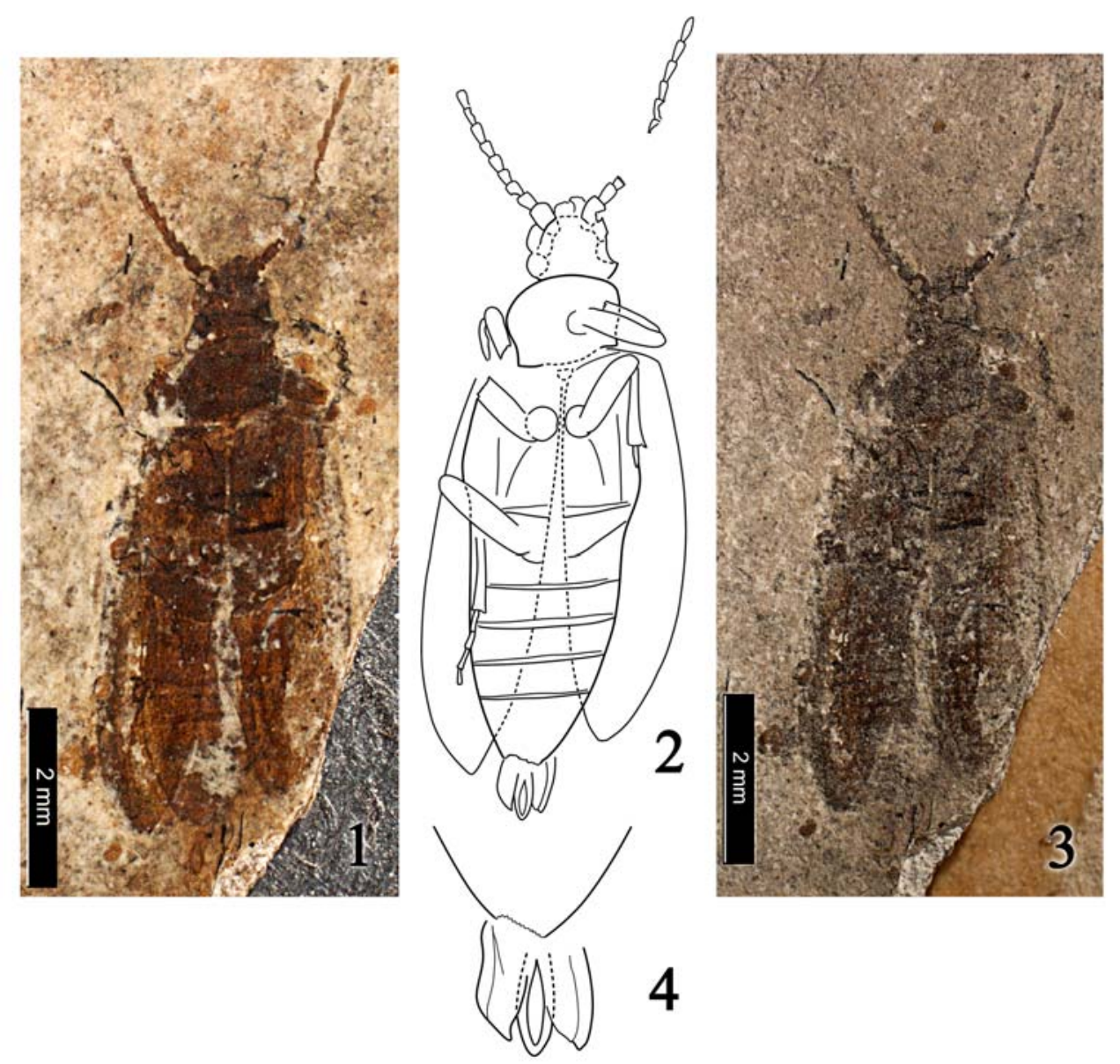

Figs 1-4. Mesocupes (Mesocupes) primitivus Martynov, 1926 (neotype "PIN 2452/682", photographed under Leica MZ 9.0 with camera DFC290); Upper Jurassic, Oxfordian (or/and Kimmeridgian); Kazakhstan, Karatau: 1 - print covered by alcohol; 2 - body, ventral, with broken lines for outlines of dorsal structures of head and sutural edges of elytra; 3 - dry print; 4 - aedeagus. Length of specimen $6.4 \mathrm{~mm}$.

Рис. 1-4. Mesocupes (Mesocupes) primitivus Martynov, 1926 (неотип "PIN 2452/682", фотографии, выполненные на микроскопе Leica MZ 9.0 с камерой DFC290); верхняя юра, оксфордский (или/и кимериджский) яруса; Казахстан, Каратау: 1 - отпечаток, покрытый спиртом; 2 - тело, снизу; прерывистой линией показаны очертания верхних структур головы и шовных краев надкрылий; 3 сухой отпечаток; 4 - эдеагус. Длина экземпляра 6,4 мм.

differences in the shape and venation of the elytra, shape of the head and pronotum, sculpture of the head, antennae and pronotum, and also in the length of the prosternum (for more details see also the Notes to the description of the subgenus Cainomerga subgen.n.).

Diagnosis. Body elongate oval to rather elongate of small to medium size (3.0-19.0 $\mathrm{mm})$. Integument with moderately coarse sculpture and punctation; large suboval, subpolygo- nal or somewhat transverse cells of elytra arranged into ten or more long longitudinal rows interspaced by weak veins of more or less subequal development. Head usually subtriangular (to subquadrangular or suboval), with more or less projecting temples; dorsal surface with weak or not raised tubercles and longitudinal convexities (usually nearly obliterated), antennal insertions open (not covered by tubercles) or slightly covered by tubercles. Mandibles moderately to 
rather strongly developed, and arcuately to angularly curved at outer edge before stout bidentate apex. Antennae subfiliform and moderately long; antennomere 1 (scape) and other antennomeres subcylindrical to slightly subconical, various proportions or scape sometimes swollen. Pronotum diverse in shape, with gently sloping to somewhat explanate sides, anterior angles frequently not projecting, surface usually tuberculate and with weak median carina. Part of prosternum before procoxae usually much longer than procoxae, although it in subgenus Mesocupes s.str. more or less shorter. Elytra with more or less arcuate lateral edges, subacute apices and usually gently sloping at sides; A1 usually distinct along entire length, other main veins, if distinct, mostly clear in basal half and distally frequently becoming obsolete and without clear trace of fusion. Abdominal ventrite 1 clearly longer than each of ventrites $2-4$. Legs moderately thin, frequently comparatively long, with straight protibiae and narrow tarsi. Aedeagus of Cupes-type with wide flattened parameres.

Comparison. This genus is the most diverse of the subfamily, but it can be distinguished after the characters used in the above key to genera and subgenera. The genus Mesocupes s.lato is somewhat similar to Latocupes, but differs from it in the comparatively narrowly separated antennal insertions, not strongly transverse pronotum without widely explanate sides, not or only slightly transverse elytral cells, the absence of fusion of primary veins at the elytral apices, the lack of clear Y-shaped depression on the frons and the short antennomere 2. The comparatively large eyes of some Mesocupes (particularly in M. (Mesocupes) spinosus comb.n.) are known also in members of Cupopsis gen.n. and Menatops gen.n., however, the mentioned species of Mesocupes differs from Cupopsis svitkoi comb.n. in the greater transverse, but not elongate diameter of eyes, not concave frons along the anterior portion of the eyes, the more widely separated antennal insertions and the lack of pair of strong tubercles in anterior part edge of frons partly covering antennal insertions; it differs from Menatops in the more or less smaller eyes with great distance between them and the absence of fusion between of primary veins on the elytra, but also from $M$. orbiculatus comb.n. in the not strongly transverse head, not strongly transverse pronotum (less than twice as wide as long). In addition, Mesocupes s.lato can be distinguished from Chalepocarabus - by the transverse pronotum, the markedly longer antennae, the usually wider body with the not strongly acuminate elytral apices and also by the larger cells arranged in the clearly expressed rows on the elytra; from Cupidium - by the longer prosternum before the procoxae and the protibia not curved at apex; from Kirghizocupes — by the longer antennae, the head with lack of both raised tubercles over the antennal insertions and Y-shaped depression on the frons, and also by the gently sloping elytral sides; from Miocupes - by the much shorter temples, not parallel veins and the rows of cells on the elytra with the larger cells; from Priacmopsis — by the much smaller body size, the longer abdominal ventrite 1 , weak (if raised) tubercles on the dorsal surface of the head and the longer metacoxae; from Gracilicupes - by the head wider than prothorax and with the lack of raised tubercles on the dorsal surface, the usually longer prosternum before the procoxae, the shorter sclerites of the legs and particularly by the structure of aedeagus; from Priacma - by the longer abdominal ventrite 1 , weak primary veins on elytra without fusion at apices and particularly by the structure of the aedeagus; from Furcicupes - by the usually much longer prosternum before procoxae; from Apriacma gen.n. and Cretomerga gen.n. - by at least the ten long longitudinal rows of cells and the absence of fusion of primary veins on the elytra, the usually gently sloping elytral sides and usually lack of Y- or V-shaped depression on the head, and from Cretomerga gen.n. also by the longer prosternum before the narrowly separated procoxae. Besides, this genus is very distinct from the recent and fossil genera and subgenera with the strongly raised primary veins on the elytra (Adinolepis, Ascioplaga, Cupes, Paracupoides subgen.n., Taxopsis gen.n., Prolixocupes and Rhipsideigma) by the widely separated antennal insertions, the absence of strongly raised upper tubercles on the 
head, the usually more robust body, the absence of fusion of primary veins on the elytra and the usually gently sloping elytral sides; also from Adinolepis, Ascioplaga, Cupes, Prolixocupes, Rhipsideigma and Taxopsis gen.n. - by the 10 long longitudinal rows of cells on elytra; also from Paracupoides subgen.n. - by the subacute or rounded (not truncate) elytral apices. Finally, Mesocupes differs from Paracupes s.lato in the weak tubercles (if raised) over the more widely separated antennal insertions and the subacute or rounded (not truncate) elytral apices.

Notes on variability. This genus is very diverse and shows a mosaic distribution of different characters. Here it is regarded as divided into three subgenera, but hiati between them are not always clear. Besides, the head shows a variabily in many characters analogous to those in Cupes, but the upper tubercles on the head usually are not so raised, or if the tubercles over the antennal insertions or in the distal half are present, they are apparently more or less weak. The shape of the pronotum among representatives of this genus is rather variable; however the ground plan of this group is quite characteristic of the Cupedinae with the rather convex disk, the more or less raised median carina and the gently sloping to (sub) explanate sides. The length of the abdominal ventrite 1 is also variable, although it is always more or less longer than each of ventrites 2-4 and not more than twice as long as ventrite 2 . The elytra of the congeners are usually gently sloping at sides but in Mesocupes (Anaglyphites) capitatus (Ponomarenko, 1966), comb.n., they demonstrate a rather sharp inflection to the steep lateral slopes.

\section{Subgenus Mesocupes s.str.}

Composition. This subgenus includes, except the type species (Mesocupes primitivus), M. (Mesocupes) bidens Ponomarenko, 1964; M. (M.) minor Ponomarenko, 1968; M. (M.) paulus (Ponomarenko, 1964), comb.n. [Anaglyphites]; M. (M.) spinosus Ponomarenko, 1964; M. (M.) zherikhini (Soriano et Delclós 2006), comb.n. [Anaglyphites].

Locality and stratigraphy. For Martynov's and Ponomarenko's species: Karatau; Mikhailovka, Galkino, Tchokhaj, Kara-Bas-Tau, right bank of Kashkar-Ata River valley, outcrops near village Uspenovka (Uspenskoye), KaraTau Range, Algabass District, Chimkent Region, Kazakhstan; late Jurassic, Oxfordian (or/ and Kimmeridgian), Karabastau Formation; for Soriano's and Delclós' species: Spain, Cuenca, $4 \mathrm{~km}$ NE from village Cierva, Las Hoyas; early Cretaceous, Barremian.

Diagnosis. Body elongate oval of medium size $(6.4-8.4 \mathrm{~mm})$. Elytra with usually rather large suboval to polygonal cells arranged into 10 or 11 long longitudinal rows (sometimes rows are not clearly expressed) interspaced by very weak veins partly fused at apex, at least A1 and $\mathrm{CuA}$ fused. Head usually subtriangular and moderately narrowing anteriorly, without expressed Y- or V-shaped depression, well projecting temples. Antennae subfiliform and moderately long (reaching body midlength); antennomere 1 (scape) usually longer than following antennomeres; antennomere 2 (pedicel) and following flagellomeres comparable in length. Pronotum with arcuate sides, its anterior and posterior edges slightly convex to subrectilinear, surface more or less obliterated at disk, anterior angles rounded. Prosternum before procoxae about as long as procoxae or somewhat longer. Elytra somewhat less than twice as long as wide combined or slightly longer, with broadly arcuate lateral edges, arcuately narrowing to conjointly subacute apices and apparently gently sloping sides; Abdominal ventrite 1 clearly longer than each of ventrites 2-4 and hypopygidium as long as ventrite 1 or longer and rounded at apex.

Comparison. See below the Comparison to the subgenus Cainomerga subgen.n.

\section{Mesocupes (Mesocupes) primitivus Mar- tynov, 1926}

$$
\text { Figs } 1-4 \text {. }
$$

Mesocupes primitivus Martynov, 1926: 6; Ponomarenko, 1964: 58 (designation of neotype and redescription).

Neotype. "PIN-2452-682" designated by Ponomarenko (1964: 58), male, print of dorsal surface of the complete specimen with traced outlines of the most ventral sclerites and the exposed aedeagus, but with missing a part of antennomeres, right eye, part of protibiae, protarsi, left mesotibia and mesotarsus, right distal mesotarsomeres, and right posterior leg. 
Notes. Since the holotype of this species had been lost, in order to provide a reliable typification, a neotype was designated and some corrections to the description were made (Ponomarenko, 1964). The holotype was somewhat larger (length $7.5 \mathrm{~mm}$ ) than the neotype. However, Ponomarenko (1969) studied many specimens of this species and mentioned its body size ranging $6.6-7.5 \mathrm{~mm}$. This species seems to have shown some variability in shape of the pronotum. Therefore, the neotype is characterized by the pronotum somewhat different from what was drawn by Ponomarenko (1968: 59, fig. 4a, 1969: 108, fig. 58a). Ponomarenko also mentioned that the pronotum of this species was twice as wide as long (Ponomarenko, 1969: 108), yet both in his drawing and in the drawing of the original description the pronotum was depicted not so wide.

Locality and stratigraphy. Karatau; Mikhailovka, Galkino, Tchokhaj, Kara-BasTau, right bank of Kashkar-Ata River valley, outcrops near village Uspenovka (Uspenskoye), Kara-Tau Range, Algabass District, Chimkent Region, Kazakhstan; late Jurassic, Oxfordian (or/and Kimmeridgian), Karabastau Formation.

Comparison. This species is characterized by the somewhat "generalized" appearance and has a medium body size; the pronotum subquadrangular with somewhat arcuate sides, the distinct posterior angles and the rounded anterior angles. It differs from Mesocupes (Mesocupes) bidens Ponomarenko, 1964 in the narrower pronotum with the widely rounded anterior angles; from M. (M.) minor Ponomarenko, 1968 in the larger (longer and wider) pronotum (markedly wider than head) and the conjointly subacute elytra apices; from M. (M.) paulus (Ponomarenko, 1964), comb.n. [Anaglyphites] in the longer pronotum with the distinct posterior angles (not rounded) and the longer antennae; from M. (M.) spinosus Ponomarenko, 1964 in the widely rounded anterior angles of the pronotum and the shorter antennae; from $M$. (M.) zherikhini (Soriano et Delclós, 2006), comb.n. [Anaglyphites] in the longer antennae, the distinct posterior angles of the pronotum and the longer abdominal ventrite 1 .

Addition to the description. Length 6.4 $\mathrm{mm}$. Shape of head and pronotum somewhat different from the drawing in the redescription by Ponomarenko (1964): head wider with larger eyes (right eye missing and left eye shifted posteriorly), temples gently narrowing posteriorly (not projecting outwards as in redescription), dorsal surface slightly tuberculate, antennal insertions apparently open and moderately separated; pronotum about 1.5 times as wide as long, with arcuate sides shallowly sinuate at posterior angles, distinct posterior angles and rounded. Elytra apparently with more than 10 long longitudinal rows of more or less oval cells. Prosternum before procoxae about as long as procoxae (procoxae located at middle of prothorax). Abdominal ventrites overlapping. Exposed aedeagus including heavily sclerotised penis trunk with long subapical window and less heavily sclerotised and rather wide flattened parameres with apices curved inwards.

\section{Cainomerga subgen.n.}

Type species Mesocupes (Cainomerga) brevicornis sp.n., fossil.

Etymology. The name of this new subgenus is formed from the name of geological era Cenozoic (= Cainozoic from Greek katvó

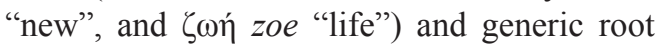
"merga" ("Bimerga", "Merga", "Tenomerga", "Cretomerga"). Gender feminine.

Composition. Except the type species, $M$. (C.) immaculatus (Piton, 1940), comb.n., M. (C.) fraternus sp.n., M.(C.) palaeocenicus sp.n., and $M .(C$.$) ponti sp.n.$

Olympus SCX9 с камерой Olympus; 6 - тело; снизу, прерывистой линией показаны очертания шовных краев и жилок надкрылий; пунктиром показаны верхние структуры головы (бугорки на голове); 7 - сухой отпечаток, сфотографированный на микроскопе Nikon SMZ1500 c Microscope Eyepiece Camera 9.0MP Aptina Color CMOS MU900; 8 - голова, сфотографированная на растровом электронном микроскопе (SEM); 9 - вершина брюшка, сфотографированная на растровом электронном микроскопе (SEM). Длина экземпляра 18,7 мм. 

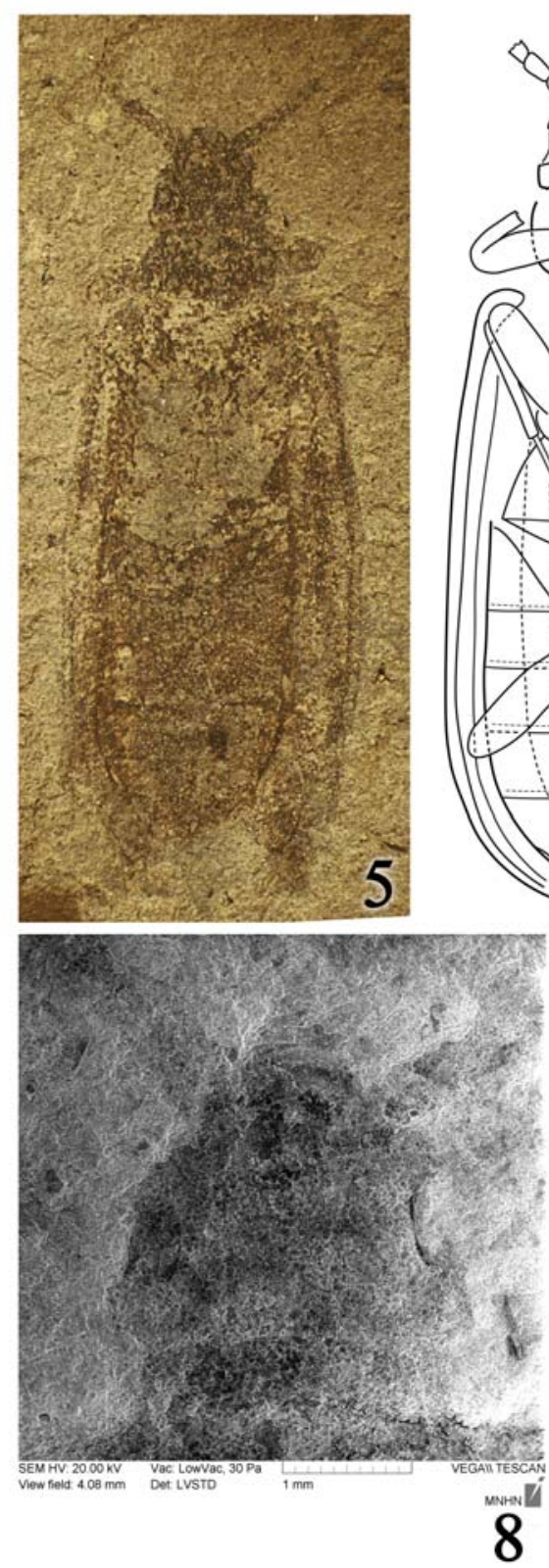
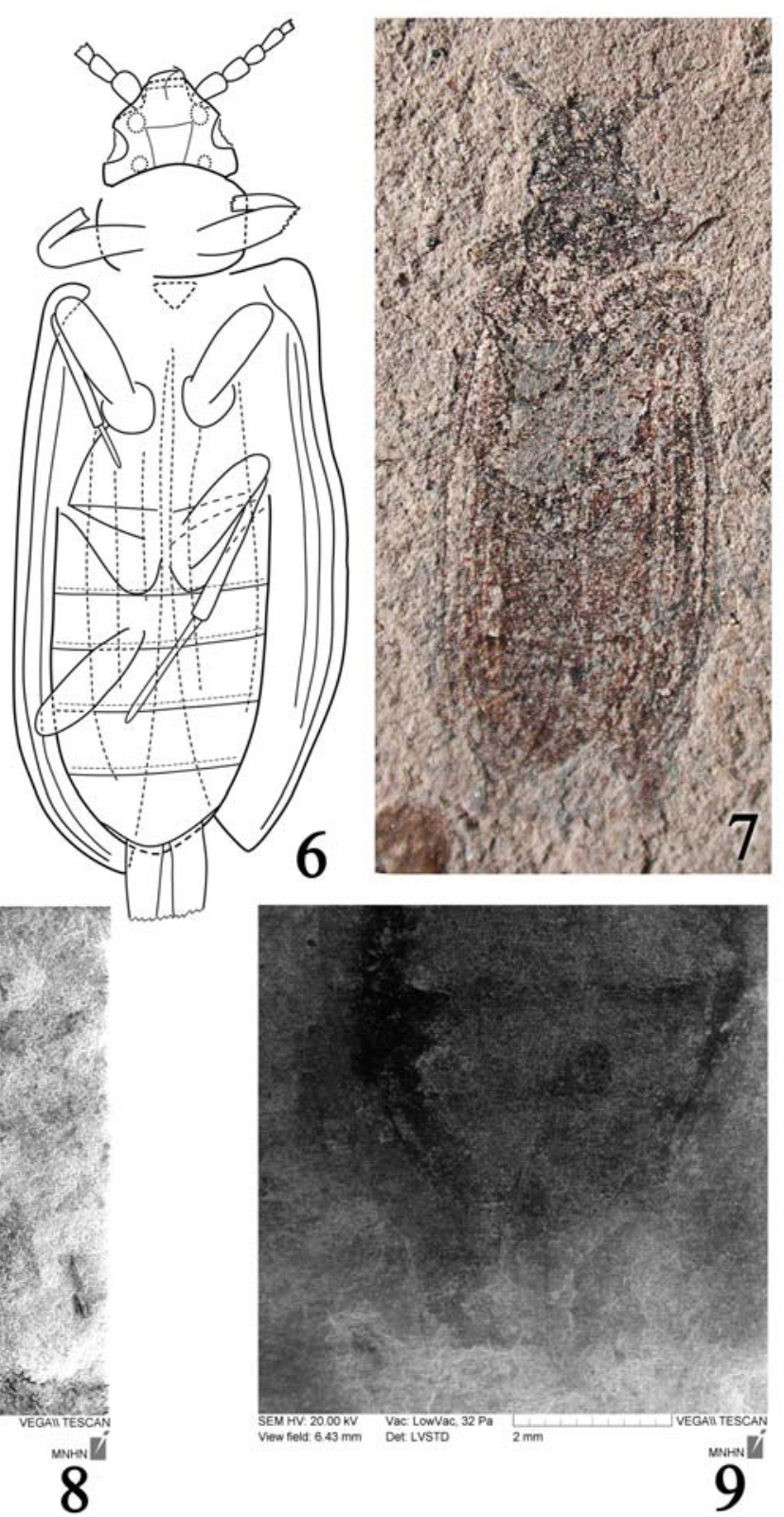

Figs 5-9. Mesocupes (Cainomerga) immaculatus (Piton, 1940), comb.n. (holotype "MNHN R07012"); Paleogene, Paleocene; France, Menat: 5 - dry print, photographed under stereomicroscope Olympus SCX9; 6 - body, ventral, with broken lines for outlines of sutural edges and veins of elytra, and dotted lines outlines of dorsal structures of head (tubercles on head); 7 - dry print, photographed under stereomicroscope Nikon SMZ1500 with Microscope Eyepiece Camera 9.0MP Aptina Color CMOS MU900; 8 - micrograms of head, photographed under scanning electron microscope (SEM); 9 - micrograms of abdominal apex, photographed under scanning electron microscope (SEM). Length of specimen $18.7 \mathrm{~mm}$.

Рис. 5-9. Mesocupes (Cainomerga) immaculatus (Piton, 1940), comb.n. (голотип "MNHN R07012"); палеоген, палеоцен; Франция, Мена: 5 - сухой отпечаток, сфотографированный на микроскопе 
Diagnosis. Body elongate oval of comparatively large size $(16.5-18.5 \mathrm{~mm})$. Integument with moderately coarse sculpture and punctation; large subquadrangular to somewhat transverse, arranged into 10 or 11 long longitudinal rows interspaced by weak secondary and slightly raised primary veins; A1 apparenly rectilinearly reaching elytral apex but without fusing with $\mathrm{CuA}$ and other primary veins before apex. Head suboval (transverse or elongate), with moderately large eyes and temples; dorsal surface without tubercles; antennal insertions moderately widely separated and open. Mandibles moderately or weakly raised and arcuately curved at outer edge. Antennae subfiliform and comparatively short (reaching elytral shoulders) to moderately long (reaching body midlength); antennomere 1 (scape) and other antennomeres various in shape and length. Pronotum rather various in shape, its anterior and posterior edge subreclilinear or convex, more or less obliterated at disk and with median elevated carina and somewhat subexplanate at sides, anterior and postgerior angles with distinct top and sometimes projecting or rounded. Part of prosternum before procoxae about as long or slightly longer than procoxae. Elytra about or somewhat more than twice as long as wide combined, with broadly arcuate lateral edges, arcuately narrowing to conjointly subsubacute, gently sloping sides and (sub) explanate along edges, primary veins weakly raised, $\mathrm{CuA}$ and $\mathrm{A} 1$ fused at apex and cells are more or less transverse. Abdominal ventrite 1 much longer than each of ventrites 2-4 or in $M$. (C.) fraternus sp.n. and $M$. (C.) immaculatus comb.n. with ventrites 1-3 more or less comparable in length and hypopygidium as long as ventrite 1. Legs rather thin, comparatively long, apparently with straight protibia and more or less widened tarsi.

Comparison. This new subgenus can be diagnosed after the above key to genera and subgenera. In stead of a considerable variability of the included species in different structures, they can be united in one taxon thanks to their general appearance, the shape of the elytra and the abdominal ventrites, and also thanks to the character of the elytral venation and the cells. It is rather similar to species of Mesocupes s.str. by many characters, but differs from the latter in the usually rather slender and larger body, and the particularly subquadrangular to transverse cells in the longitudinal rows of the elytra. Cainomerga subgen.n. differs from the subgenus Anaglyphites stat.n. in the larger body with the narrower elytra, the transverse or subquadrangular cells and the more clear primary veins on the elytra, and also in the absence of Yshaped depression on the frons. Besides, species of the new subgenus, in contrast to those in other subgenera, are characterised with the comparatively long and narrow legs, and also all members of Cainomerga subgen.n. have been collected in outcrop from the Paleocene while those of Mesocupes s.str. and Anaglyphites stat.n. are known only from the early Cretaceous and late Jurassic.

Some members of this subgenus seem to have almost narrowest and longest legs among cupedines (only the legs of Gracilicupes are comparable) and differ from other cupedine genera with 10 and more long longitudinal rows of cells on elytra in the following characters:

- Chalepocarabus in the much larger body with the less arcuate elytral sides, the expressed veins and the transverse or subquadrate cells on elytra, the shorter and somewhat transverse pronotum;

- Cupidium in the much longer prosternum before the procoxae and the conjointly subacute elytral apices;

- Gracilicupes in the primary veins without clear fusion at apices, the smaller eyes, the absence of Y-shaped depression on the frons, the more or less longer prosternum before the procoxae, the pronotum markedly wider than head and the distinct anterior and posterior angles, and also in the usually much longer abdominal ventrite 1 ;

- Kirghizocupes in the primary veins without clear fusion at apices, the shorter head (not so narrow and elongate), the absence of Yshaped depression on the frons, the pronotum not so wider than head, and the not so acuminate elytral apices which are conjointly ended (not separately), and the frequently much longer abdominal ventrite 1 ; 
- Menatops gen.n. in the larger body, the primary veins without clear fusion at apices, the longer head with the larger eyes and the moderately long anterior frontal part, the narrower and longer elytra with the more arcuate sides and the more narrowing apices, and also in the usually much longer abdominal ventrite 1 ;

- Paracupes s.str. and Paracupoides subgen.n. in the somewhat curved ouline of the body, the primary veins without clear fusion at apices, the absence of tubercles on the frons, the open antennal insertions, the shorter prosternum, the conjointly acute elytral apices (not truncate) and the not curved protibiae;

- Priacma in the somewhat curved outline of the body, the primary veins without clear fusion at apices, the absence of convexities on the frons, the open antennal insertions, the shorter prosternum, the conjointly acute elytral apices (not truncate), and the longer abdominal ventrite 1 .

Cainomerga subgen.n. differs from the recent taxa with nine long longitudinal rows on the elytra, not only in the number of these rows, but also in the somewhat curved ouline of the body, the primary veins without clear fusion at apices, the absence of very prominent convexities on the frons, the frequently shorter prosternum before the procoxae, and the gently sloping elytral sides. Also Cainomerga subgen.n. differs from the fossil taxa with nine long longitudinal rows on the elytra in the number of these rows and also in the following characters:

- Apriacma gen.n., Cupes and Furcicupes in the somewhat curved ouline of the body, the primary veins without clear fusion at apices, the frequently shorter prosternum before the procoxae and the longer abdominal ventrites; and also from from Apriacma gen.n. and Furcicupes in the absence of Y-shaped depression on the frons; and also from Cupes also in the absence of very prominent convexities on the frons and the straight protibia;

- Cretomerga gen.n. in the primary veins without clear fusion at apices, the more oval head with the wider neck, the absence of Yshaped depression on the frons and the narrowly separated procoxae;
- Cupopsis gen.n. in the head with the smaller eyes and not concave along the anterior part of their edges;

- Latocupes $(?=$ Pulchicupes $)$ in the more slender body, the primary veins without clear fusion at apices, the less transverse cells on the elytral disk, and the absence of Y-shaped depression on the frons;

- Miocupes in the more slender body, the usually narrow and the not transverse head with the not strongly projecting temples, the longer pronotum, the shorter prosternum before the procoxae, and also in the not parallel primary veins and the more distinct cells on the disk of the elytra;

- Taxopsis gen.n. in the smaller body-size, the less transverse cells on the elytral disk, narrow prosternal process, and the primary veins without clear fusion at apices.

Finally, Cainomerga subgen.n. differs from the forms with unclear number of the long longitudinal rows of cells, namely from Priacmopsis in the smaller and much more slender body, and the usually shorter prosternum before the procoxae, and from Cupidium in the more slender body, and the conjointly acute elytral apices (not separately rounded).

\section{Mesocupes (Cainomerga) brevicornis sp.n. Figs 18-26.}

Holotype. "MNHN.F.A51119", print and counterprint. The holotype is with somewhat smoothed outlines of sclerites (not clearly visible most sclerites), although the elytral sculpture is more or less clear, with missing 3-11 segments of one antenna, one anterior and one posterior tibiae, almost all tarsomeres, the apex of one elytron and the apex of the abdomen; the prothoracic segment with an angular break. The rock has been collected by A. Nel in the historical site of the ancient quarry of "Noir d'Auvergne" where Piton investigated in the years 1935-1940. The piece of rock is comparatively hard and slightly becoming loose.

Locality and stratigraphy. Paleocene, Menat (see Materals and methods). 

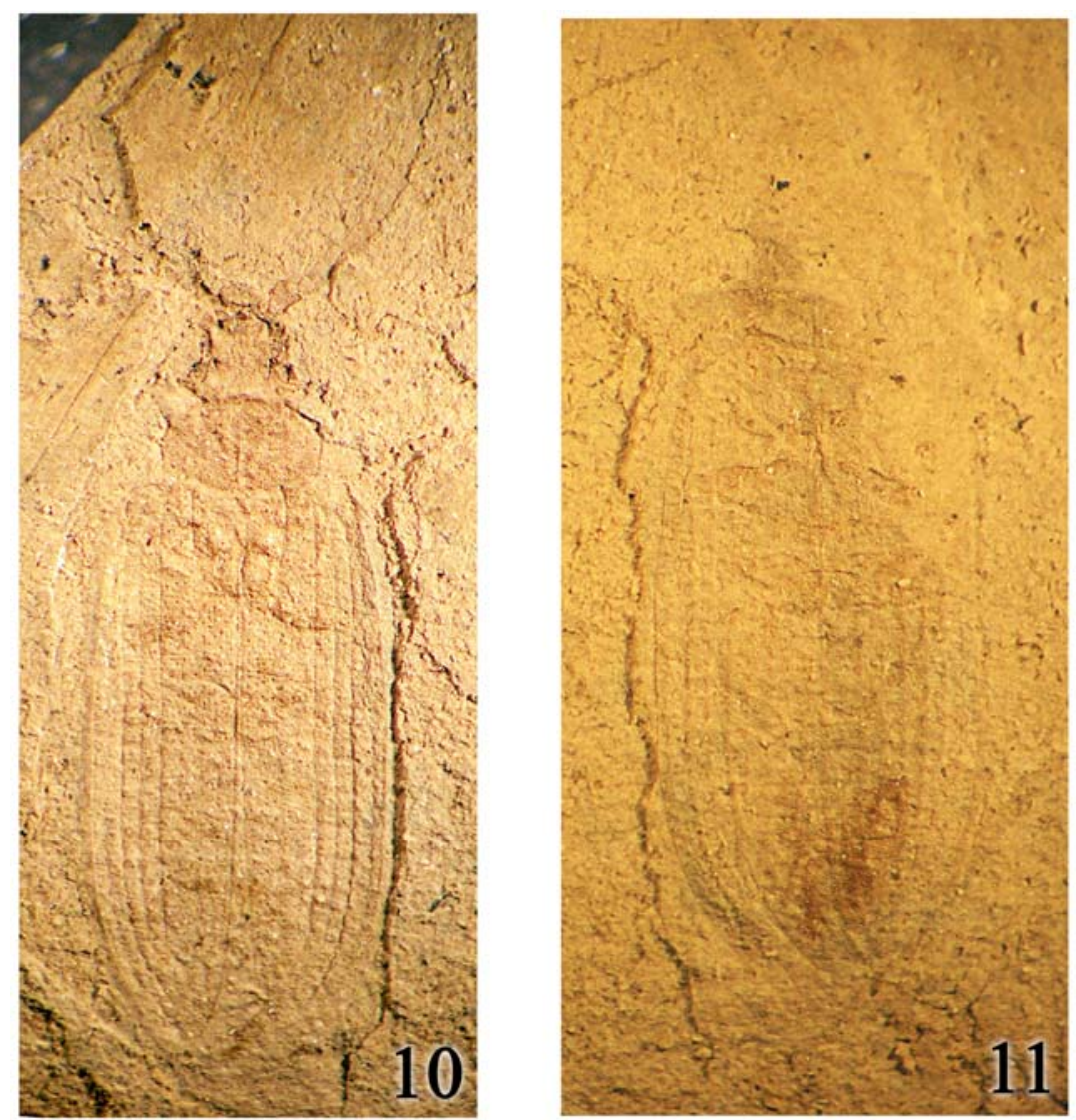

Figs 10-11. Menatops orbiculatus (Kirejtshuk, Nel et Collomb, 2010), comb.n. (holotype "MNT-05-198", dry print and counterprint, photographed under Olympus SCX9 with camera Olympus); Paleogene, Paleocene; France, Menat: 10 - print; 11 - counterprint. Length of specimen $9.1 \mathrm{~mm}$.

Рис. 10-11. Menatops orbiculatus (Kirejtshuk, Nel et Collomb, 2010), comb.n. (голотип "MNT-05-198”, сухие отпечаток и противоотпечаток; фотографии, выполненные на микроскопе Olympus SCX9 c камерой Olympus); палеоген, палеоцен; Франция, Мена: 10 - отпечаток; 11 - противоотпечаток. Длина экземпляра 9,1 мм.

Etymology. The epithet of this new species is composed from the Latin "brevis" (short, small) and "cornu" or "cornus" (beak, horn, antler etc.) and referred to its short antennae.

Diagnosis. This new species is very well characterized by its short antennae and the pe-

culiar pronotum with the subtruncate narrow anterior edge and the arcuate sides. It can be diagnosed among the species known from Menat after the key to species of the subgenus (see below). In addition to this key, M. (C.) brevicornis sp.n. also differs from $M$. (C.) fraternus sp.n.

Рис. 12-17. Menatops orbiculatus (Kirejtshuk, Nel et Collomb, 2010), comb.n. (голотип "MNT-05-198", сухой отпечаток); палеоген, палеоцен; Франция, Мена: 12 - голова и проторакс, сфотографированные на микроскопе Olympus SCX9 с камерой Olympus; 13 - голова и переднеспинка, сверху; прерывистой линией очерчен ментум; 14 - тело с усиками, сфотографированное на растровом электронном микроскопе (SEM); 15 - метавентрит и средние бедра, сфотографированные на растровом электронном микроскопе (SEM); 16 - тело без усиков, сфотографированное на растровом электронном микроскопе (SEM); 17 - голова и переднегрудь, сфотографированные на растровом электронном микроскопе (SEM). Длина экземпляра 9,1 мм. 

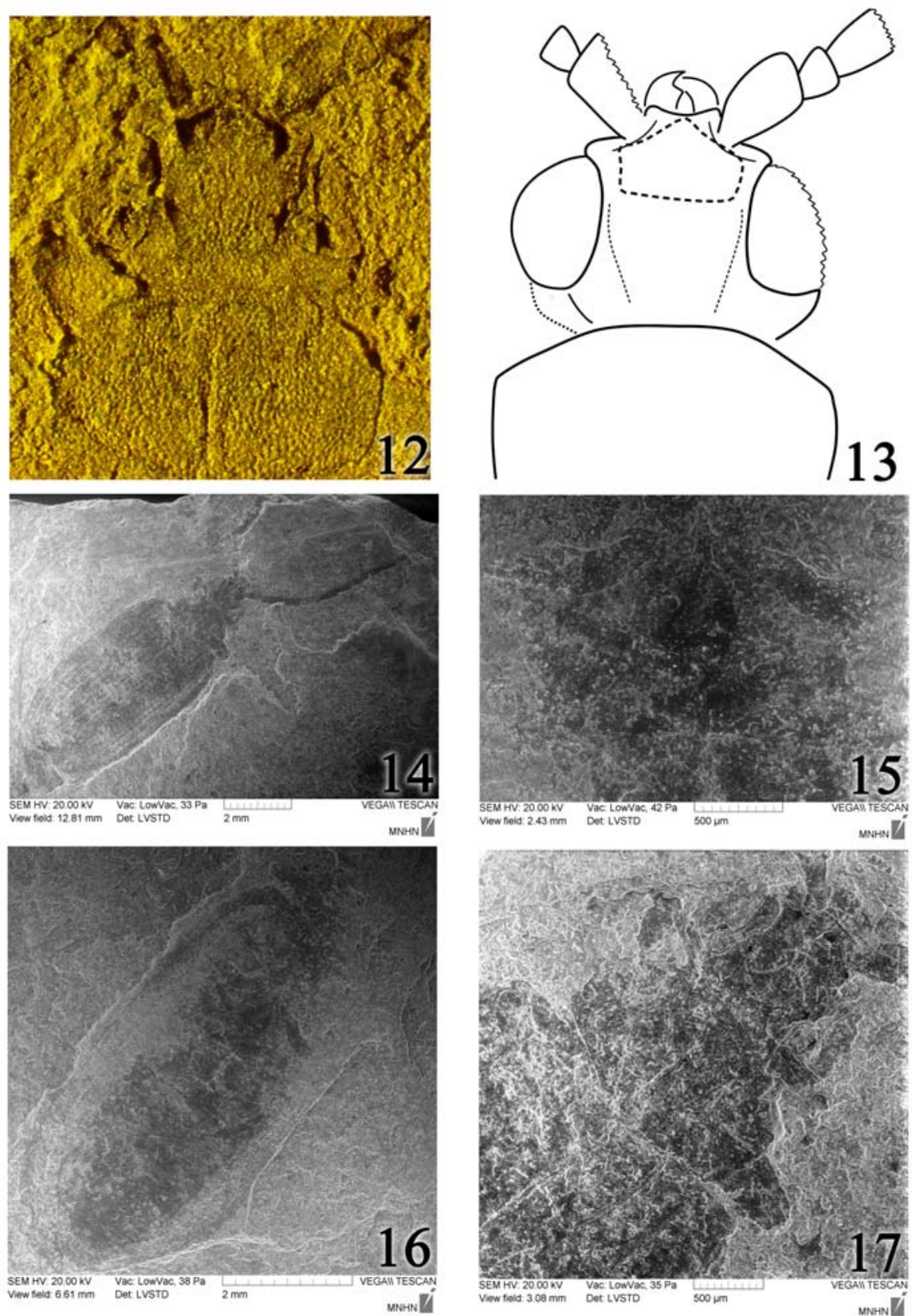

Figs 12-17. Menatops orbiculatus (Kirejtshuk, Nel et Collomb, 2010), comb.n. (holotype "MNT-05-198", dry print); Paleogene, Paleocene; France, Menat: 12 - head and prothorax, photographed under Olympus SCX9 with camera Olympus; 13 - head and pronotum, dorsal, with broken line outlined mentum; 14 micrograms of body with antennae, photographed under scanning electron microscope (SEM); 15 micrograms of metaventrite with mesofemora, photographed under scanning electron microscope (SEM); 16 - micrograms of body without antennae, photographed under scanning electron microscope (SEM); 17 - micrograms of head and prothorax, photographed under scanning electron microscope (SEM). Length of specimen $9.1 \mathrm{~mm}$. 

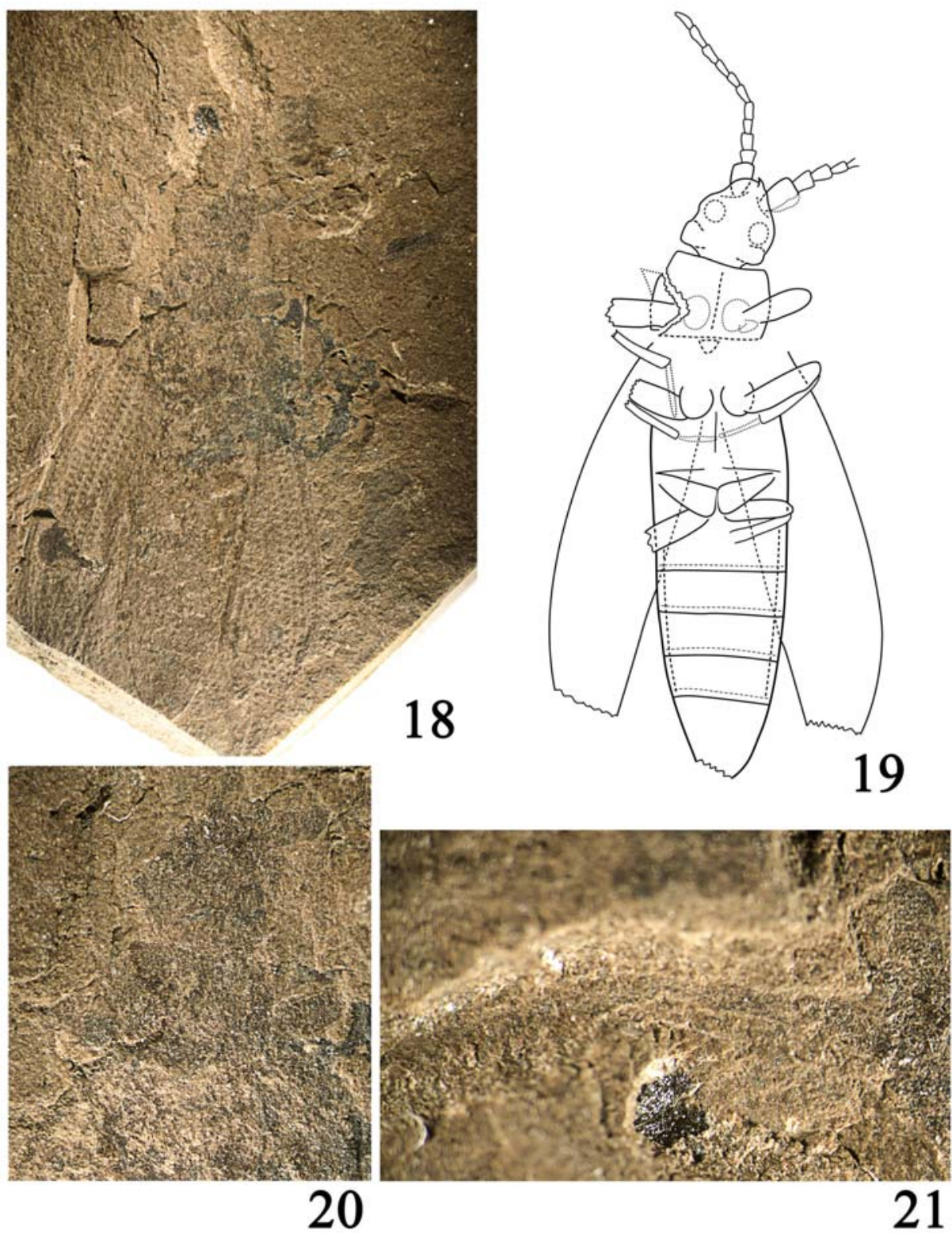

21

Figs 18-21. Mesocupes (Cainomerga) brevicornis sp.n. (holotype "MNHN.F.A51119", dry print, photographed under Olympus SCX9 with camera Olympus); Paleogene, Paleocene; France, Menat: 18 print; 19 - body, ventral, with broken line outlined sutural edges of elytra, edges of laterosternites and structures on upper surface of head (tubercles), and also dotted lines outlined traced edges of scape, procoxae, protrochanter and tarsi; 20 - head and prothorax; 21 - left antenna. Length of specimen $18.3 \mathrm{~mm}$.

Рис. 18-21. Mesocupes (Cainomerga) brevicornis sp.n. (голотип “MNHN.F.A51119”, сухой отпечаток, сфотографированный на микроскопе Olympus SCX9 с камерой Olympus); палеоген, палеоцен; Франция, Мена: 18 - отпечаток; 19 - тело, снизу; прерывистой линией очерчены шовные края надкрылий, края латеростернитов, верхних структур головы (бугорки); пунктиром показаны прослеживающиеся очертания скапуса, прококсы переднего вертлуга и лапок; 20 - голова и переднегрудь; 21 - левый усик. Длина экземпляра 18,3 мм. 

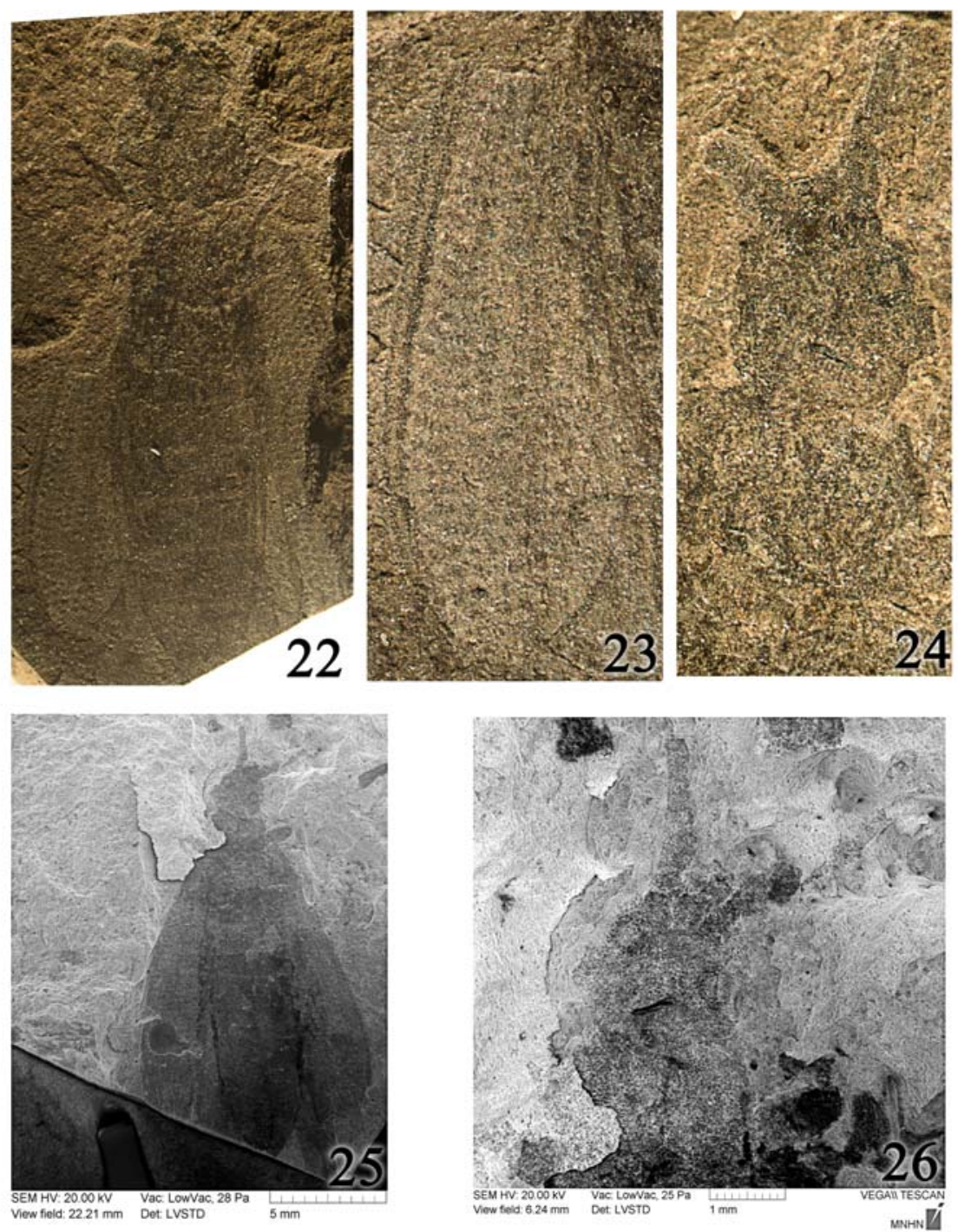

Figs 22-26. Mesocupes (Cainomerga) brevicornis sp.n. (holotype "MNHN.F.A51119"); Paleogene, Paleocene; France, Menat: 22 - body of dry counterprint, photographed under Olympus SCX9 with camera Olympus; 23 - apex of left elytron of dry counterprint under Olympus SCX9 with camera Olympus; 24 head and prothorax of dry counterprint, photographed under Olympus SCX9 with camera Olympus; 25 micrograms of body of print, photographed under scanning electron microscope (SEM); 26 - micrograms of head of print, photographed under scanning electron microscope (SEM). Length of specimen $18.3 \mathrm{~mm}$. Рпс. 22-26. Mesocupes (Cainomerga) brevicornis sp.n. (голотип "MNHN.F.A51119"); палеоген, палеоцен; Франция, Мена: 22 - тело сухого противоотпечатка, сфотографированное под микроскопом Olympus SCX9 с камерой Olympus; 23 - вершина левого надкрылья сухого противоотпечатка, сфотографированная под микроскопом Olympus SCX9 с камерой Olympus; 24 - голова и переднегрудь сухого противоотпечатка, сфотографированные под микроскопом Olympus SCX9 с камерой Olympus; 25 - тело отпечатка, сфотографированное на растровом электронном микроскопе (SEM); 26 - голова отпечатка, сфотографированная на растровом электронном микроскопе (SEM). Длина экземпляра 18,3 мм. 
in the sparse sculpture of the underside, the shorter scape and particularly following antennomeres, the shorter legs, apparently the longer metacoxae and the much longer abdominal ventrites; from M. (C.) immaculatus comb.n. in the rather narrowly separated mesocoxae, somewhat arcuate elytral sides, the longer all abdominal ventrites (particularly the hypopygidium), the much denser and finer sculpture of the underside integument; from $M$. (C.) palaeocenicus sp.n. in the oblique metacoxae, the longer each of abdominal ventrites; from $M$. (C.) ponti sp.n. in the longer prosternum before the procoxae, the more narrowly separated mesocoxae, the somewhat longer abdominal ventrite 1 and hypopygidium.

Description. Body length (with elytra) 18.3 $\mathrm{mm}$, width apparently $6.5 \mathrm{~mm}$, elytral length 9.1 $\mathrm{mm}$. Body elongate; apparently slightly to moderately convex dorsally and subflattened ventrally. Integument of head and pronotum with moderately large regular punctures separated by about one puncture diameter or less; metaventrite and many other underside sclerites with comparably fine and moderately sparse punctures (interspaces between punctures about as great as puncture diameter); elytra with large transverse to somewhat subpolygonal cells arranged in at least 10 (probably 11) longitudinal rows between veins.

Head subpentagonal (probably because of fossilization) and without traces of upper tubercles, somewhat longer than wide, apparently widest at temples (rather projecting and subangular), with moderately large oval eyes; antennal insertions open. Mandibles apparently moderately developed, slightly exposed beyond labrum, with gently curved outer edge. Antennae comparatively short; scape longest and rather thick; antennomere 2 (pedicel) subcylindrical, somewhat shorter than flagellomeres, narrower than scape and wider than flagellomeres; flagellomeres subequal in length and ultimate one acuminate. Prothorax moderately short; pronotum about one and $1 / 3$ as wide as long, apparently slightly and gently convex, its sides seemingly widely (sub) explanate and slightly narrowing anteriorly, its sides arcuate, anterior edge subconcave, anterior and posterior angles stump and with distinct top; prosternum before procoxae at least as long as procoxae, procoxae apparently narrowly separated. Mesoventrite apparently about as long as prosternum. Mesocoxae moderately large and distance between them about $1 / 4$ of their diameter. Metaventrite about half as long as wide at base. Metacoxae rather oblique, about three times as wide as long and their mesal parts moderately projecting posteriorly. Abdomen with overlapping ventrites; ventrite 1 longest (nearly twice as long as following ones), ventrites $2-4$ subequal in length and much shorter than hypopygidium (ventrite 5); hypopygidium apparently rounded at apex. Elytra slightly wider than prothorax, with broadly arcuate sides, together more than twice as long as wide, apparently moderately convex; with slightly expressed veins.

Femora comparable in shape and proportions, gently curved along anterior and posterior edges, about three times as long as wide. Tibiae apparently somewhat shorter than femora and very thin. Tarsi represented by short traces of one fore and both intermediate legs.

\section{Mesocupes (Cainomerga) fraternus sp.n.} Figs 139-141.

Holotype. "MNHN.F.A52773" ("NEL 1452 "), print. The specimen has the more or less clear outlines of its legs and abdominal ventrites, but the outlines of the thoracic sclerites and antennomeres are rather obscure, and also the terminal antennomeres and apical part of abdomen are missing. The specimen originated from a new, small outcrop near the south-east of the village of Menat, the piece of rock is rather soft and fragile.

Locality and stratigraphy. Paleocene, Menat (see Materals and methods).

Etymology. The epithet of this new species (Latin "brotherly", "fraternal") refers to a considerable similarity of it to Mesocupes (Cainomerga) brevicornis sp.n.

Diagnosis. This new species is characterised by the shortest frons within its consubgeners, the densest sculpture of the underside integument, the comparatively long abdominal ven- 
trites $2-4$ and the comparatively large eyes. It has the similar outlines of the katepisternal sutures and the metacoxae to those in $M$. (C.) brevicornis sp.n., although the metacoxae of the latter apparently are longer. However its underside integument is much more densely sculptured, the legs and antennae are somewhat longer, the abdominal ventrite 1 is markedly shorter and the pronotum is apparently widening anteriad. The particular differences of these species are in the shape of their head, the temples and size of eyes, although these differences could partly be caused by peculiar circumstances in fossilization. Mesocupes (C.) fraternus sp.n. can be diagnosed after the below key to species, Besides, this new species differs from $M$. (C.) immaculatus comb.n. in the longer abdominal ventrites, the gular sutures divergent in the posterior part, the much finer and rather dense sculpture of the underside; from $M$. (C.) palaeocenicus sp.n. in the much larger eyes, the longer legs, the shorter metacoxae and the much shorter abdominal ventrite 1; from M. (C.) ponti sp.n. in the much larger eyes, the oblique and shorter metacoxae.

Description. Body length (without apical parts of abdomen and elytra) $14.6 \mathrm{~mm}$, width apparently $6.3 \mathrm{~mm}$. Integument of underside with rather fine and very dense regular (somewhere subcontiguous) punctures; metaventrite with comparably fine and sparse punctures; elytra with large transverse to subpolygonal cells arranged longitudinal rows between veins.

Head transversally subtriangular (probably because of fossilization) widely separated gular sutures, apparently widest at temples (somewhat projecting and rounded), apparently with comparatively large oval eyes; antennal insertions apparently open. Mandibles comparatively small, slightly exposed beyond labrum, with gently curved outer edge. Antennae moderately long; scape longest and rather thick; antennomere 2 (pedicel) subcylindrical, somewhat shorter than flagellomeres, narrower than scape and wider than flagellomeres; flagellomeres 4-7 subequal in length, each of somewhat shorter than scape and somewhat longer than each of antennomeres 2 and 3. Prothorax rather short; its sides widening anteriad, anterior prosternal edge subconcave, anterior and posterior angles rather acute and with distinct top; prosternum before procoxae at least as long as procoxae. Mesoventrite apparently about as long as prosternum. Mesocoxae not visible. Metaventrite about 2/3 as long as wide at base. Metacoxae slightly oblique, their mesal parts modeartely projecting posteriorly. Abdomen with overlapping ventrites; ventrites 1-3 subequal in length. Elytra somewhat wider than prothorax, apparently with broadly arcuate sides, with slightly expressed veins.

Femora comparable in shape and proportions, gently curved along anterior and posterior edges, about four times as long as wide. Tibiae apparently somewhat shorter than femora and very thin. Tarsi represented by moderately long and widened tarsomeres.

Mesocupes (Cainomerga) immaculatus (Piton, 1940), comb.n. Figs 5-9.

Zonabris immaculatus Piton, 1940: 194 (Meloidae Gyllenhal, 1810).

Holotype. "MNHN R07012", "Zonabris immaculatus Piton, TYPE", male, print of the entire body with a mixture of outlines of both dorsal and ventral sclerites, and also with unclear remains of the sculpture of the integument and the exposed aedeagus, but with missing distal antennomeres, all tarsi (except right metatarsus), anterior part of protibia, right mesotibia and left metatibia. The specimen is entombed in the rock collected by Louis Piton, in the historical site of the ancient quarry of "Noir d'Auvergne" where Piton investigated in the years 1935-1940, this piece of rock is comparatively smooth and rather consistent.

Notes. The holotype of this species demonstrates all features of Cupedidae, but not Meloidae where it was initially put (Piton, 1940). It is here considered as belonging to the Cenozoic group of the genus Mesocupes. This interpretation is confirmed also by the structure of its aedeagus similar to that of the type species of this genus. The elytral cells of the holotype have unclear and obliterated edges, although some 
cells in the lateral longitudinal rows demonstrate the subquadrate to transversely quadrangular outlines.

Locality and stratigraphy. Paleocene, Menat (see Materals and methods).

Diagnosis. This new species is very well characterized by its comparatively robust body, subpentagonal pronotum with rounded angles, very long and rather oblique metacoxae, most coarse and sparse sculpture of the underside. The particular features of this species are the more widely separated mesocoxae, and metacoxae nearly reaching posterior edge of abdominal ventrite 1 . It can be easily diagnosed among the species known from Menat after the key to species (see below). In addition to this key, $M$. (C.) immaculatus comb.n. also differs from $M$. (C.) brevicornis sp.n. in the subparallel elytral sides and shorter all abdominal ventrites (particularly hypopygidium); from $M$. (C.) fraternus sp.n. in the markedly shorter head, shorter abdominal ventrites, gular sutures convergent in the posterior part; from $M$. (C.) palaeocenicus sp.n. in the more widely separated gular sutures, longer abdominal ventrites 2-4; from $M$. (C.) ponti sp.n. in the apparently longer prosternum before procoxae.

Redescription. Body length (with elytra) $18.7 \mathrm{~mm}$, width $7.8 \mathrm{~mm}$, elytral length $9.1 \mathrm{~mm}$. Body elongate; apparently slightly to moderately convex dorsally and sub-flattened ventrally. Integument of dorsal and ventral sclerites with moderately coarse sculpture including coarse and dense oval punctures, interspaces between them apparently coarsely microreticulate; elytra with subquadrate to transversely quadrangular cells arranged in rows between veins (visible only rows at lateral edge of elytra).

Head subtriangular and with scarcely traced upper tubercles but with paramedian longitudinal lines, slightly wider than long, widest at temples, with moderately large oval eyes; antennal insertions open. Mandibles apparently moderately developed, slightly exposed beyond labrum, with gently curved outer edge. Antennae apparently moderately long; scape slightly longer and thicker than following antennomeres; antennomere 2 (pedicel) comparable in- length with basal flagellomeres (preserved left antennomeres 3 and 4). Prothorax moderately short; pronotum about one and $1 / 3$ as wide as long, apparently slightly and gently convex, its sides seemingly widely (sub) explanate and slightly wider anteriorly; prosternum before procoxae at least as long as procoxae, procoxae apparently narrowly separated. Mesoventrite apparently about as long as prosternum. Mesocoxae moderately large and distance between them about $2 / 3$ of their diameter. Metepisterna nearly four times as long as wide. Metaventrite about half as long as wide at base. Metacoxae moderately oblique, about twice as wide as long and their mesal parts strongly projecting posteriorly. Abdomen with overlapping ventrites; ventrite 1 longest and nearly as long as hypopygidium and somewhat longer than each of ventrites 2-4; pygidium and hypopygidium widely rounded at apex. Elytra much wider than prothorax, with subparallel sides, together about 2.3 times as long as wide, apparently moderately convex; $\mathrm{R}$ and $\mathrm{M}$ somewhat more clear than other main veins (may be as sequence of preservation) but $\mathrm{CuA}$ and $\mathrm{A} 1$ very slightly traced.

Femora comparable in shape and proportions, gently curved along anterior and posterior edges, 2.5-3.0 times as long as wide, metafemora somewhat longer than pro- and mesofemora. Tibiae apparently somewhat longer than femora and very thin. Metatarsus slightly shorter than metatibia.

Aedeagus with broken apex, slightly sclerotized, including of moderately long subparallelsided penis trunk and wide flattened parameres markedly shorter than penis trunk.

\section{Mesocupes (Cainomerga) palaeocenicus} sp.n.

Figs 27-31.

Holotype. "MNHN.F.A51117”, “11/05/ 1970", print, collection of Philippe Olivier. The print of the holotype is with somewhat smoothed outlines of sclerites (not visible anterior part of head except apices of the mandibles), with missing apical atennomeres of one antenna, apex of one mesotibia, most part of tarsomeres and 

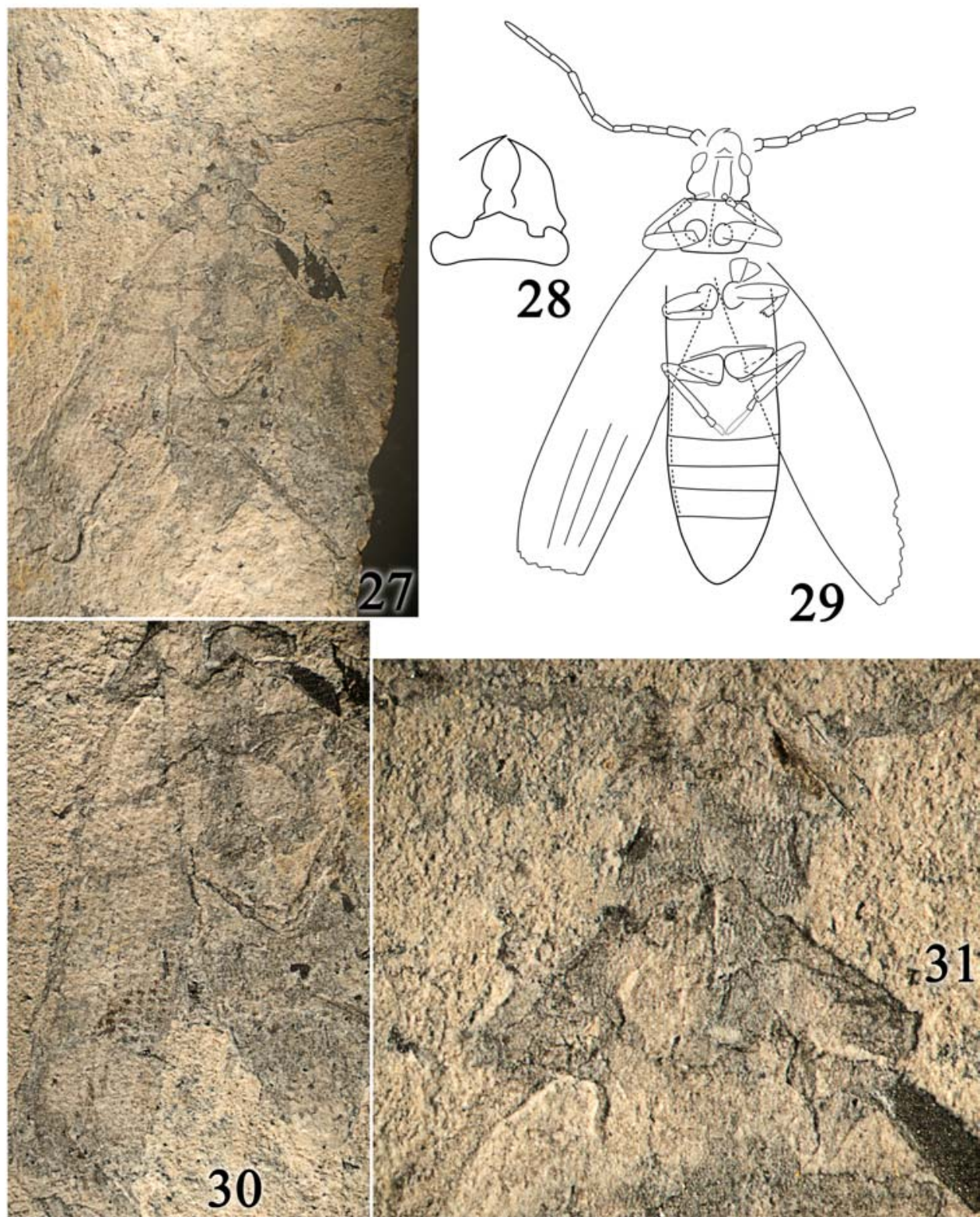

Figs 27-31. Mesocupes (Cainomerga) palaeocenicus sp.n. (holotype "MNHN.F.A51117", dry print, photographed under Olympus SCX9 with camera Olympus); Paleogene, Paleocene; France, Menat: 27 body; 28 - mentum and mandibles, ventral; 29 — body, ventral, with broken line outlined sutural edges of elytra, edges of laterosternites and median carina of pronotum, and also dotted lines outlined traced tarsi; 30 - part of body with elytron; 31 - head and prothoracic segment. Length of specimen $16.5 \mathrm{~mm}$.

Рис. 27-31. Mesocupes (Cainomerga) palaeocenicus sp.n. (голотип “MNHN.F.A51117”, сухой отпечаток, сфотографированный под микроскопом Olympus SCX9 с камерой Olympus); палеоген, палеоцен; Франция, Мена: 27 - тело; 28 - ментум и мандибулы, снизу; 29 - тело, снизу; прерывистой линией очерчены шовные края надкрылий, края латеростернитов, медиальный гребень переднеспинки; пунктиром показаны прослеживающиеся очертания лапок; 30 - часть тела с надкрыльем; 31 голова и переднегрудь. Длина экземпляра 16,5 мм. 
elytral apices. The rock has been collected by Philippe Olivier in the historical site of the ancient quarry of "Noir d'Auvergne" where Piton investigated in the years 1935-1940. This piece of rock is comparatively smooth and slightly becoming loose.

Locality and stratigraphy. Paleocene, Menat (see Materals and methods).

Etymology. The epithet of this new species refers to time (epoch) of its origin.

Diagnosis. This new species is very well characterized by its hexagonal pronotum and very long antennomere 2 . It can be easily diagnosed among the species known from Menat after the key to species (see below). In addition to this key, M. (C.) palaeocenicus sp.n. differs from $M$. (C.) brevicornis sp.n. in the less slender body, the longer antennae, the narrowly separated (subcontiguous) mesocoxae, the much shorter ventrite 1 and hypopygidium; from $M$. (C.) fraternus sp.n. in the much longer head with the much smaller eyes, the shorter legs, the longer metacoxae, the much longer abdominal ventrite 1 and markedly denser sculpture of the underside; from M. (C.) immaculatus comb.n. in the more narrowly separated gular sutures, the narrowly separated mesocoxae, the shorter abdominal ventrites $2-4$, the strongly denser and finer sculpture of the underside; from $M$. (C.) ponti sp.n. in the larger eyes, the longer prosternum before the procoxae, the longer ventrite 1 and hypopygidium.

Description. Body length (with elytra) 16.5 $\mathrm{mm}$, width $4.6 \mathrm{~mm}$, elytral length $12.8 \mathrm{~mm}$. Body elongate and rather slender; apparently slightly to moderately convex dorsally and subflattened ventrally. Integument of dorsal and ventral sclerites with moderately coarse sculpture including coarse and dense oval punctures, very narrow interspaces between them (less than one puncture diameter) apparently coarsely microreticulate; metaventrite apparently with somewhat obliterated punctation; elytra with transverse to subpolygonal cells arranged in at least 11 rows between veins.

Head subtriangular and with a pair of small and round upper tubercles at the middle of eyes, slightly wider than long, widest at angularly projecting temples, with rather large oval eyes and with distance between them about as great as transverse eye diameter; antennal insertions open. Mandibles apparently moderately developed and represented in print only by their apices. Antennae comparatively long and reaching the middle of abdominal ventrite 1; scape not very thick; antennomere 2 (pedicel) somewhat longer than each of three following flagellomeres and subequl in length to each of six apical flagellomeres (antennomeres 6-11). Gular sutures subparallel to slightly curved in basal half of epicranium. Prothorax moderately short; pronotum subhexagonal (widest at the middle) with distinct anterior and posterior angles and widest at the middle, straight anterior and posterior edges, about 1.5 times as wide as long, apparently slightly and gently convex, its sides seemingly widely (sub) explanate and slightly wider anteriorly; prosternum before procoxae at least as long as procoxae and longitudinal stripe along intire length (to apex of prosternal process), procoxae moderately narrowly separated. Mesoventrite somewhat shorter than prosternum. Mesocoxae moderately large and distance between them very narrow. Metaventrite somewhat longer than half its width at base. Metacoxae transverse, about twice as wide as long and their mesal parts strongly projecting posteriorly. Abdomen with ventrite 1 longest and more than three times as long as each of ventrites 2-4 and somewhat longer than hypopygidium (ventrite 5); pygidium and hypopygidium widely rounded at apex. Elytra slightly wider than prothorax, with sub-parallel sides, somewhat more than twice as long as wide combined, primary and secondary veins equally raised.

Femora comparable in shape and proportions gently curved along anterior and posterior edges, 3.0 times or more as long as wide, metafemora somewhat longer than pro- and mesofemora. Tibiae more or less longer than femora and very thin. Metatarsus comparatively wide.

\section{Mesocupes (Cainomerga) ponti sp.n.} Figs 32-40.

Holotype. "MNHN.F.A51116”, “11/05/ 1970, 63-Menat", print and counterprint, col- 

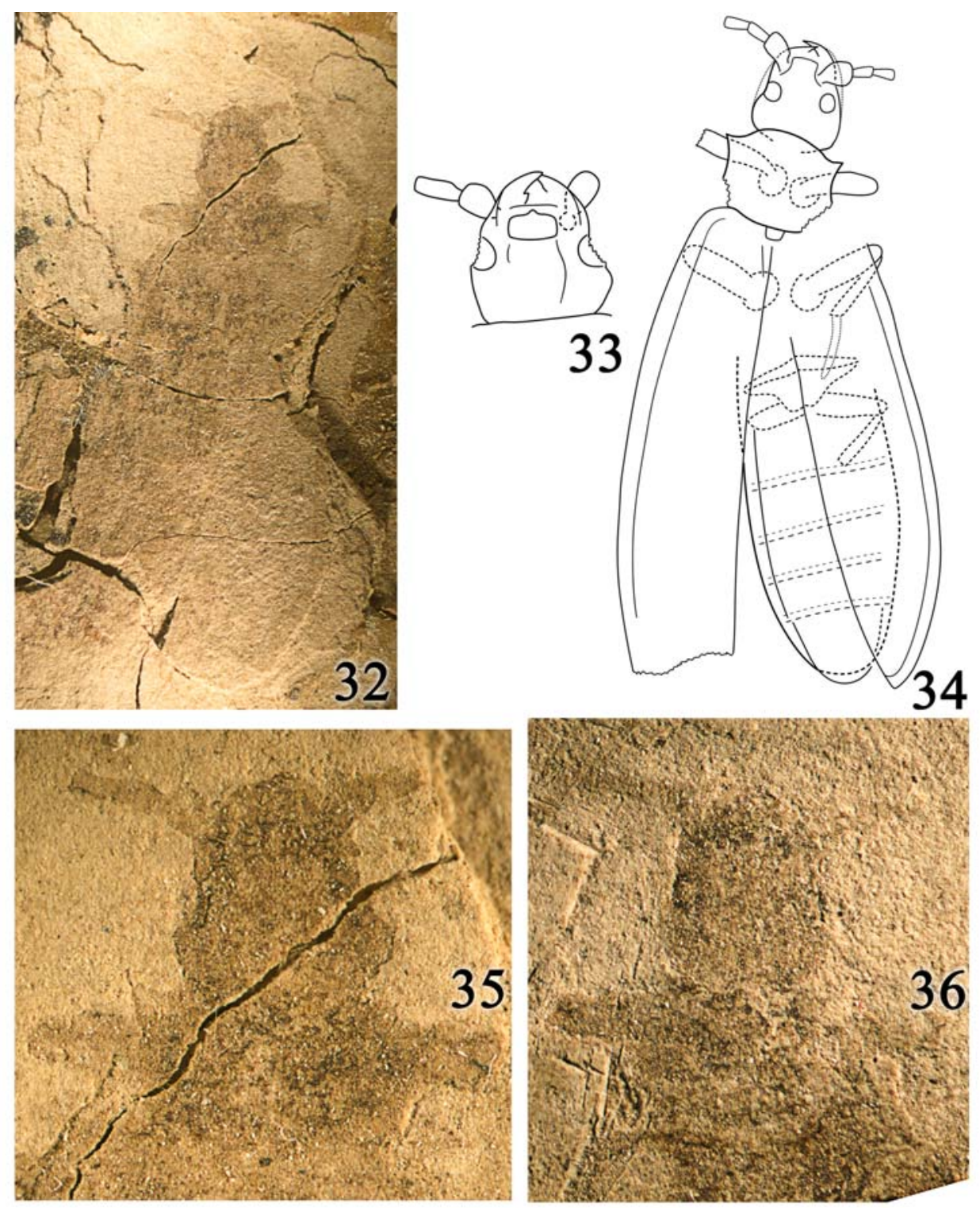

Figs 32-36. Mesocupes (Cainomerga) ponti sp.n. (holotype "MNHN.F.A51116", dry print and counterprint, photographed under Olympus SCX9 with camera Olympus); Paleogene, Paleocene; France, Menat: 32 counterprint, body; 33 - counterprint, head, ventral, with broken line outlined scape; 34 - print, body, dorsal, with broken line outlined edges of ventral sclerites; and dotted line apparent edges of compressed head and traced mesotarsus; 35 - counterprint, head and prothoracic segment with appendages; 36 - print, head and prothoracic segment with appendages. Length of specimen $18.5 \mathrm{~mm}$.

Рис. 32-36. Mesocupes (Cainomerga) ponti sp.n. (голотип "MNHN.F.A51116", сухие отпечаток и противоотпечаток, сфотографированные под микроскопом Olympus SCX9 с камерой Olympus); палеоген, палеоцен; Франция, Мена: 32 - тело противоотпечатка; 33 - голова противоотпечатка, снизу; прерывистой линией очерчены края скапуса; 34 - тело отпечатка, сверху; прерывистой линией очерчены нижние склериты; пунктиром возможные края сдавленной головы и прослеживающиеся очертания мезотарсуса; 35 - голова и переднегрудной сегмент противоотпечатка с придатками; 36 - голова и переднегрудной сегмент отпечатка с придатками. Длина экземпляра 18,5 мм. 

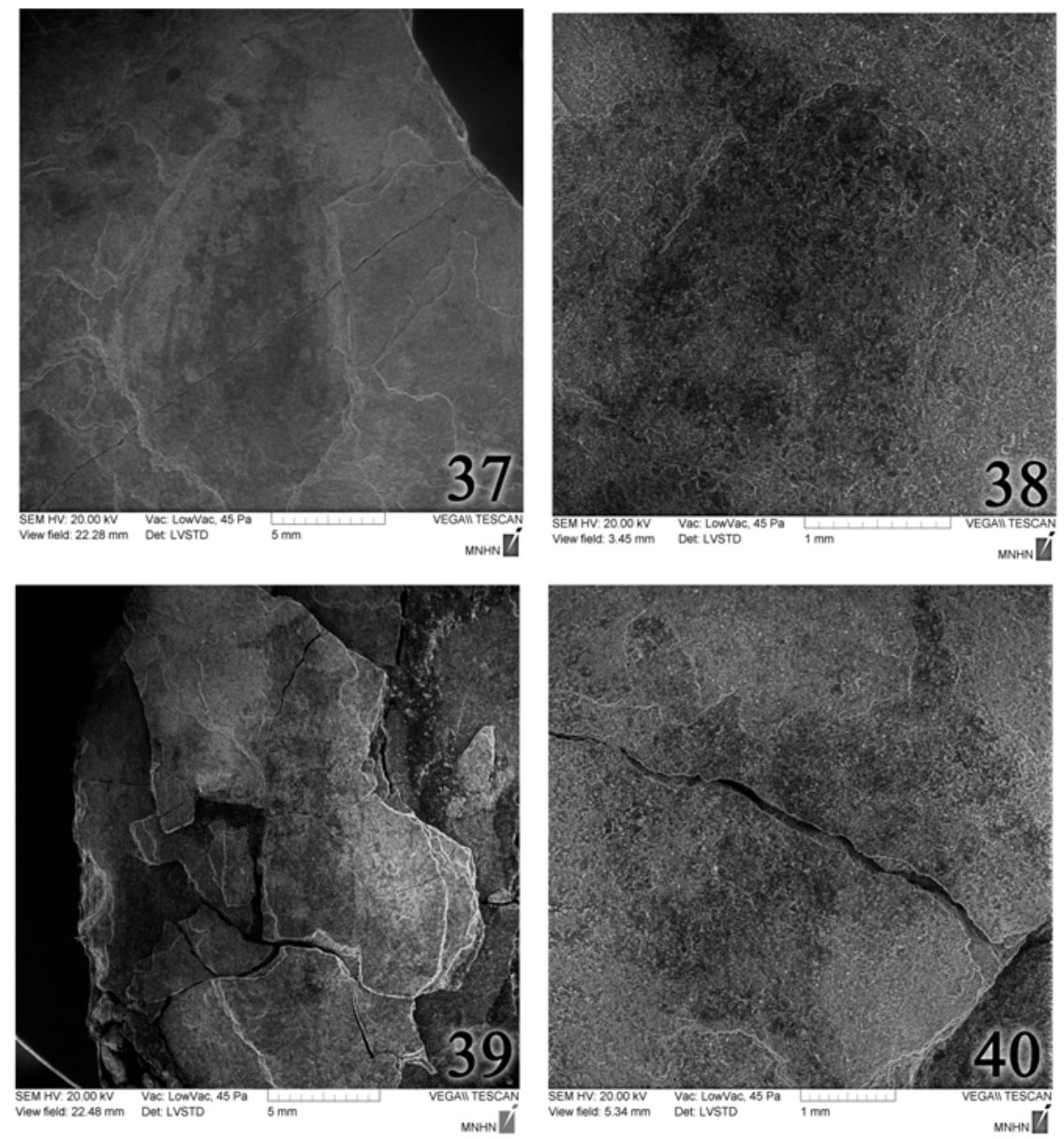

Figs 37-40. Mesocupes (Cainomerga) ponti sp.n. (holotype "MNHN.F.A51116", print and counterprint, micrograms, photographed under scanning electron microscope (SEM)); Paleogene, Paleocene; France, Menat: 37 - counterprint, body; 38 - counterprint, head; 39 - print, body; 40 - print, head and prothoracic segment with appendages. Length of specimen $18.5 \mathrm{~mm}$.

Рис. 37-40. Mesocupes (Cainomerga) ponti sp.n. (голотип "MNHN.F.A51116", отпечаток и противоотпечаток, сфотографированные на растровом электронном микроскопе (SEM)); палеоген, палеоцен; Франция, Мена: 37 - тело противоотпечатка; 38 - голова противоотпечатка; 39 - тело отпечатка; 40 - голова и переднегрудной сегмент отпечатка с придатками. Длина экземпляра 18,5 мм.

lection Philippe Olivier. The holotype has rather smoothed outlines of sclerites (most of them not clearly visible), and also rows of cells on the elytra, but missing 4-11 segments of both antennae, tibiae except one intermedial and one posterior tibiae, almost all tarsomeres, apex of one elytron and apex of abdomen. The rock has been collected by Philippe Olivier in the historical site of the ancient quarry of "Noir d'Auvergne" where Piton investigated in the years 19351940. This piece of rock is comparatively smooth and slightly becoming loose.

Locality and stratigraphy. Paleocene, Menat (see Materals and methods).

Etymology. The epithet of this new species is devoted to Sylvain Pont who assisted the authors in the studies of beetles with electronic microscopy. 
Diagnosis. This new species is very well characterized by its peculiar head and pronotum, the short prosternum and the transverse metacoxae, making its identification quite easy and reliable. It can be easily diagnosed among the species known from Menat after the below key to species. In addition to this key as well as shape of head and prothorax, M. (C.) ponti sp.n. differs from $M$. (C.) brevicornis sp.n. in the longer basal antennomeres and shorter abdominal ventrite 1 and hypopygidium; from $M$. (C.) fraternus sp.n. in the longer frons, the somewhat more sparse sculpture of the underside, the comparatively short abdominal ventrites $2-4$ and the comparatively small eyes; from $M$. (C.) immaculatus comb.n. in the slender body, the shorter and transverse metacoxae ended far from the posterior edge of the abdominal ventrite 1 , the more narrowly separated mesocoxae, the dense and finer sculpture of the underside; from M. (C.) palaeocenicus sp.n. in the much shorter basal antennomeres and the less narrowly separated mesocoxae.

Description. Body length (with elytra) 18.5 $\mathrm{mm}$, width $4.5 \mathrm{~mm}$, elytral length $12.3 \mathrm{~mm}$. Body elongate; apparently slightly to moderately convex dorsally and subflattened ventrally. Integument of dorsal and ventral sclerites with moderately coarse sculpture including coarse and very dense oval punctures, interspaces between them apparently coarsely microreticulate; metaventrite with somewhat larger and shallower punctures; elytra with subpolygonal to more or less transverse cells arranged in 10 (or could be 11) rows between veins.

Head elongate and with scarcely traced upper tubercles, slightly wider than long, widest at gently rounded temples, with comparatively small oval eyes at the middle of head; antennal insertions open. Mandibles apparently well developed, well exposed beyond labrum, with gently curved outer edge. Antennae represented only by three basal antennomeres; scape rather swollen, much thisker and somewhat longer than each of antennomeres 2 and 3 with subequal length. Prothorax moderately short; pronotum about one and $1 / 3$ as wide as long, apparently slightly and gently convex, its sides seeming- ly widely (sub) explanate and slightly wider anteriorly, from the middle widened to acutely projecting anterior angles, its anterior edge convex; prosternum before procoxae at least as long as procoxae, procoxae rather narrowly separated. Mesoventrite shorter than prosternum. Mesocoxae moderately large and distance between them about $1 / 3$ of their diameter. Metaventrite about half as long as wide at base. Metacoxae transverse, about twice as wide as long and their mesal parts strongly projecting posteriorly. Abdomen with overlapping ventrites; ventrite 1 about as long as hypopygidium and about 1.5 times as long as each of ventrites 2-4; pygidium and hypopygidium widely rounded at apex. Elytra apparently slightly wider than prothorax, with subparallel sides, about 2.3 times as long as wide combined, apparently moderately convex; $\mathrm{Cu}$ and $\mathrm{R}$ somewhat more clear than other main veins.

Femora comparable in shape and proportions, gently curved along anterior and posterior edges, about three times as long as wide. Tibiae apparently as long as femora and very thin. Mesotarsus slightly shorter than mesotibia.

\section{Mesocupes (Cainomerga) sp.1}

Fig. 159.

Specimen examined. "MNHN.F.A.57518" ("NEL 2200"), print with the incomplete specimen (partly pronotum and distal part of body) showing rather obliterated and unclear outlines, deposited in the comparatively soft and fragile rock. It originated from a new, small outcrop near the south-east of the village of Menat.

Locality and stratigraphy. Paleocene, Menat (see Materals and methods).

Notes. Body $12.2 \mathrm{~mm}$ long, and elytra 10.3 $\mathrm{mm}$ long. This specimen is characterised by the not slender body, the pronotum somewhat similar to that in M. (Mesocupes) primitivus with rounded sides and acuminate posterior angles, the elytra with longitudinal rows of transverse subpolygonal cells and comparatively clear primary veins, and very acute apex of last abdominal ventrite which somewhat longer than wide. Other characters are not clear, although its meta- 
coxae are apparently with transverse anterior edges, ventrites 2-4 are comparable in length and each of them slightly longer than ventrite 5 . The outlines of coxae and some of leg sclerites are very obscure. The available characters are very distinct from those in all consubgeners here described, however preservation of the specimen and lack of head with appendages make unreasonable description of a new additional species after study of this alone specimen.

\section{Mesocupes (Cainomerga) spp.}

Figs. 148, 160-162.

Specimens examined. "MNHN.F.A.52769" ("NEL 1579"), print of separate elytron with the clear veins and cells deposited in the hard rock. The specimen originated from a new, small outcrop near the south-east of the village of Menat. "MNHN.F.A.57519" ("NEL 2210"), print and counterprint with the separate elytron, deposited in the moderately soft and fragile rock. The specimen originated from a new, small outcrop near the south-east of the village of Menat. "MNHN.F.A.57520" (“Oli 685"), print of apical part of elytron with the clear veins and cells deposited in the moderately soft and fragile rock. The rock has been collected by Philippe Olivier in the historical site of the ancient quarry of "Noir d'Auvergne" where Piton investigated in the years 1935-1940. “MNHN.F.A.57521" (“Oli 314”), print of middle part of separate elytron, deposited in the moderately soft and fragile rock. The rock has been collected by Philippe Olivier in the historical site of the ancient quarry of "Noir d'Auvergne" where Piton investigated in the years 1935-1940.

Locality and stratigraphy. Paleocene, Menat (see Materals and methods).

Notes. "MNHN.F.A. 52769": Elytron 12.6 $\mathrm{mm}$ long and $3.5 \mathrm{~mm}$ wide. "MNHN.F.A. 57519": Elytron $14.6 \mathrm{~mm}$ long and $3.9 \mathrm{~mm}$ wide. The complete elytra of these specimens have the primary veins weakly expressed, fusion of $\mathrm{A} 1$ and $\mathrm{CuA}$ and 10 longitudinal rows of distinctly transverse cells and gently sloping sides. "MNHN.F.A.57520": Fragment of elytron
$4.5 \mathrm{~mm}$ long with weak primary vein and transverse cells. "MNHN.F.A. 57521": Fragment of elytron $4.1 \mathrm{~mm}$ long with the primary veins weakly expressed and transverse cells.

\subsection{Key to species of the subgenus Cain- omerga subgen.n. from Menat}

1. Pronotum widest at strongly projecting anterior angles; procoxae located at the middle of prothorax (i.e. prosternum before procoxae seemingly as long as procoxae); head only slightly narrowing before eyes; abdominal ventrite 1 about 1.5 times as long as each of ventrites $2-4$; antennomeres 2 (pedicel) and 3 subequal in length and somewhat shorter than antennomere 1 (scape); hypopygidium nearly as long as wide; body about three times as long as wide; length of body $18.5 \mathrm{~mm}$. Figs $32-40 \ldots \ldots . . M$. (C.) ponti sp.n.

- Pronotum widest at the middle; procoxae located at posterior edge of prothorax (i.e. prosternum before procoxae much longer than procoxae); head moderately narrowing before eyes; abdominal ventrite 1 about twice as long as each of ventrites $2-4$; combination of remaining characters different .. 2

2. Pronotum subhexagonal and subangular at widest place near the middle; antennomere 2 (pedicel) longer than antennomere 1 (scape) and antennomere 3; head markedly longer than wide; anterior edge of metacoxae transverse (not oblique); length of body $16.5 \mathrm{~mm}$. Figs 27-31 M. (C.) palaeocenicus sp.n.

- Pronotum not subhexagonal and subangular at widest place near the middle; antennomere 2 (pedicel) shorter than antennomere 1 (scape) and antennomere 3 ; head not longer than wide; anterior edge of metacoxae more or less oblique .

3. Head strongly transverse (nearly twice as wide as long) with very short frons before eyes; abdominal ventrite 1 only slightly longer than each of ventries 2 and 3; mandibles slightly exposed; pronotum widening to acuminate anterior angles; metacoxae short and slightly oblique; length of body (without apices of elytra and abdomen) $14.6 \mathrm{~mm}$. Figs 139-141 M. (C.) fraternus sp.n.

- Head at least 1.5 times as wide as long; abdominal ventrite 1 at least 1.5 times as long as each of ventries 2-4; mandibles usually developed; combination of other remaining characters different

4. Pronotum subpentagonal with subrectilinear sides; body more robust with abdomen less than 1.5 times as long as wide; head slightly transverse; 
metacoxae very long and rather oblique, mesally reaching posterior edge of abdominal ventrite 1 ; hypopygidium transverse; length of body 18.7 mm. Figs 5-9

. M. (C.) immaculatus (Piton, 1940), comb.n. - Pronotum not subtrapezoid and subarcuate at widest place; body more slender with abdomen about twice as long as wide; head about as long as wide; metacoxae moderately long and oblique, mesally reaching the middle of abdominal ventrite 1 ; hypopygidium markedly longer than wide; length of body $18.3 \mathrm{~mm}$. Figs $18-26 \ldots$ M. (C.) brevicornis sp.n.

\section{4. (?) Mesocupes (Cainomerga) spp.}

\section{(?) Mesocupes (Cainomerga) sp.1.}

Fig. 142.

Specimen examined. "MNHN.F.A.52768" ("Nel 1697"), print. The specimen is represented by a fragment of elytron with the length 7.0 $\mathrm{mm}$ and remains of distal part of the posterior leg in the piece of comparatively hard rock. The specimen originated from a new, small outcrop near the south-east of the village of Menat.

Locality and stratigraphy. Paleocene, Menat (see Materals and methods).

Notes. The print of the elytral apex examined demonstrates the clear transverse cells in the longitudinal rows as characteristic of species attributed to the subgenus Cainomerga subgen.n. Nevertheless this elytral apex can scarcely be associated with any species of this subgenus because it represents only a third of the entire elytron $(7.0 \mathrm{~mm})$ and respectively the length of the complete specimen having this elytral fragment should be at least $25 \mathrm{~mm}$. Besides, the apex of this elytron is not so narrow as in the members of Cainomerga subgen.n. and, therefore, it can be supposed that the beetle with this elytron could be much more robust than the cupedines included into this taxon.

\section{(?) Mesocupes (Cainomerga) sp.2.}

Fig. 164.

Specimen examined. "MNHN.F.A. 57522" ("Oli 218"), print. The specimen in lateral position is represented by the body with detached and turned abdomen without clear remains of antennae and legs, deposited in the piece of moderately soft and fragile rock. The rock has been collected by Philippe Olivier in the historical site of the ancient quarry of "Noir d'Auvergne" where Piton investigated in the years 1935-1940.

Locality and stratigraphy. Paleocene, Menat (see Materals and methods).

Notes. The print with the general length of the specimen in curved position is $12.1 \mathrm{~mm}$ and with elytron $10.0 \mathrm{~mm}$ long. It demonstrates the clear gently sloping elytral sides, weakly raised primary veins, comparatively large and slightly transverse cells in the longitudinal rows (apparently ten rows or even 11), head with rather large eyes and tubercle(s) on its upper surface, comparatively wide base of pronotum gradually narrowing anteriorly, abdomen with subequally long ventrites and with ventrite 5 slightly transverse and arcuate at apex. The many accessible features of this print are characteristic of species attributed to the subgenus Cainomerga subgen.n. and gives some emagination on the lateral appearance of the species of this genus. Nevertheless the not strongly transverse elytral cells and large eyes raise doubts in such an attribution.

\section{(?) Mesocupes (Cainomerga) sp.3} Fig. 163.

Specimen examined. "MNHN.F.A. 57523" ("Oli 674"), print. The specimen represents the separate elytron. The rock has been collected by Philippe Olivier in the historical site of the ancient quarry of "Noir d'Auvergne" where Piton investigated in the years 1935-1940.

Locality and stratigraphy. Paleocene, Menat (see Materals and methods).

Notes. The elytron $6.4 \mathrm{~mm}$ long clearly shows at least ten longitudinal rows of rather strongly transverse cells and weakly raised primary veins. Partly these characters are correspondent to those in members of Cainomerga subgen.n. However the small size of the elytron examined make it possible to doubt in such an attribution. 


\subsection{Menatops gen.n.}

Type species: Cupes orbiculatus Kirejtshuk, Nel et Colomb, 2010, fossil.

Etymology. The name of this new subgenus is formed from the name of the locality (Menat) and an abbreviated generic root "ops" (from the Greek "opsis", meaning "view, sight, appearance"). Gender masculine.

Composition. The type species and M. bartenevi sp.n.

Diagnosis. Body elongate oval, of medium size $(9.1 \mathrm{~mm})$. Integument with moderately coarse sculpture and punctation; large subquadrangular to slightly transverse on disk to polygonal or suboval cells along sides of elytra, arranged into 10 long longitudinal rows interspaced by weak secondary and distinctly raised primary veins; A1 deviating at scutellum and rectilinearly reaching elytral apex and fusing with $\mathrm{CuA}$ before apex, and then with $\mathrm{M}$ and $\mathrm{R}$. Head strongly transverse, very short before very large eyes (with transverse diameter as great as half of the distance between them), with temples narrowing behind eyes; upper surface without tubercles; antennal insertions narrowly separated and open. Mandibles moderately raised and arcuately curved at outer edge. Antennae subfiliform and moderately long (reaching body midlength); antennomere 1 (scape) subequal in length with flagellomeres or slightly longer and somewhat thicker than other antennomeres. Pronotum transverse, subhexagonal or subpentagonal, its anterior and posterior edges slightly convex, more or less smoothed (not tuberculate) at disk or with a slight median elevated carina and subexplanate on sides, anterior and posterior angles blunt and not projecting. Part of prosternum before procoxae markedly longer than procoxae, the latter located near posterior edge of pronotum. Elytra about twice as long as wide combined or 1 and $3 / 5$ as long as wide combined, with broadly arcuate lateral edges, arcuately narrowing to nearly conjointly rounded apices and steeply sloping sides. Abdominal ventrite 1 much longer than each of ventrites 2-4 and hypopygidium as long as ventrite 1. Legs moderately thin, moderately long and comparatively stout, apparently with a straight protibia.

Notes. This genus is characterized by the rather steeply sloping lateral sides of elytra which can be traced due to the strongly raised $\mathrm{R}$ and the sloping stripe of one of elytron well visible in the holotype $M$. bartenevi sp.n. The differences of both congeners of this new genus are very great (anterior edge of head and structure of antennae), althouth at the moment it is not necessary to separate them into two genera or subgenera.

Comparison. Using the above key to genera and subgenera, this new genus can be diagnosed by the extraordinary structure of the head with very large eyes and a very short anterior part of the frons, also by the peculiar shape of the pronotum. The very distinct $\mathrm{R}$ in the elytra of Menatops gen.n. finds an analogy only in the venation of Cainocups gen.n., known only from a fragment of an elytron which, in contrast to the elytra of Menatops gen.n., shows R reaching the elytral top and its consequent fusion with $\mathrm{M}$ (first), CuA (second) and A1 (third). Besides this, in addition to the above-mentioned characters in structure of the head, pronotum and elytral venation, it differs from other cupedine genera showing 10 or more long longitudinal rows of cells on the elytra in the following features:

- Anaglyphites stat.n. in the clear primary veins and the fusion of $\mathrm{A} 1$ and $\mathrm{CuA}$ on the elytra;

- Cainomerga subgen.n. in the robust body with more rectilinear elytral sides, wider and shorter elytra, somewhat shorter and thicker legs;

- Chalepocarabus in the more slender body with less strongly arcuate elytral sides, expressed veins on the elytra, the shorter and transverse pronotum, the wider and shorter elytra, the raised primary veins, and the very short antennomere 2;

- Cupidium in the longer prosternum before the procoxae and the conjointly subacute elytral apices;

- Gracilicupes in the longer prosternum, the pronotum markedly wider than the head, the 
thicker antennae with a longer and thicker scape, the shorter pronotum, the wider and shorter elytra, and the very short antennomere 2;

- Kirghizocupes in the more robust body, the pronotum not so much wider than the head, the wider and shorter elytra, and not so acuminate elytral apices which are ended conjointly, not separately;

- Mesocupes s.str. in the more robust body, the better expressed primary veins and the clear fusion of A1 and CuA on the elytra, the shorter pronotum, and the very short antennomere 2;

- Paracupes s.str. and Paracupoides gen.n. in the more robust body, the absence of tubercles on the frons, the open antennal insertions, the shorter pronotum, the wider and shorter elytra, the conjointly acute elytral apices (not truncate) and the not curved protibiae;

- Priacma in the more robust body, the absence of convexities on the frons, the open antennal insertions, the shorter pronotum, the wider and shorter elytra, the conjointly acute elytral apices, and the longer abdominal ventrite 1 .

In addition to its extraordinary structure of the head with very large eyes and a very short anterior part of the frons, Menatops gen.n. differs from the modern taxa with nine long longitudinal rows on the elytra not only in the number of these rows, but also in the more robust body with a shorter and hexagonal pronotum, the much wider elytra, and the gently sloping elytral sides. Menatops gen.n., in addition to its head with very large eyes and a very short anterior part of the frons, differs from the fossil taxa with nine long longitudinal rows on the elytra in the number of these rows and also the following characters:

- Apriacma gen.n., Cupes and Furcicupes in the more robust body, the strongly transverse pronotum with non-projecting anterior angles;

- Cretomerga gen.n. in the more robust body, the longer prosternum before narrowly separated procoxae, and the strongly transverse pronotum with non-projecting anterior angles;

- Cupopsis gen.n. in the more robust body;

- Latocupes (? = Pulchicupes) in the less transverse cells on the elytral disk;
- Miocupes in the more distinct cells on the disk of the elytra;

- Taxopsis gen.n. in the smaller body, the less transverse cells on the elytral disk, the narrow prosternal process, the strongly transverse pronotum with non-projecting anterior angles.

Finally, Menatops gen.n., in addition to its head with very large eyes and a very short anterior part of the frons, differs from the forms with an unclear number of long longitudinal rows of cells, namely, Priacmopsis in the smaller and more robust body, and from Cupidium in the more robust body, the longer prosternum before the procoxae, the non-arcuate pronotal sides, and the conjointly acute elytral apices (not separately rounded).

Note. This new genus looks very similar to Latocupes, particularly in its general appearance, the shape of the pronotum and the peculiarities of the cells on the elytral disk.

Menatops orbiculatus (Kirejtshuk, Nel et Colomb, 2010), comb.n.

Figs 10-17. 217.

Cupes orbiculatus Kirejtshuk, Nel et Colomb, 2010:

Holotype. "MNT-05-198" (MTM), print and counterprint. The specimen was collected in a new, small outcrop near the south-east end of the village of Menat and entombed in a comparatively smooth, somewhat fragile and loosened rock.

Notes. As the scales for illustrations used in the original description of this species (Kirejtshuk et al., 2010) were wrong, the true measurements of the holotype body are actually as given in the corrections to the description below. After an additional study, particularly using electron microscopy, some characters in shape of the head and pronotum have also been clarified. In the original description, this species was assigned to the genus Cupes, albeit its placement in this genus was questioned.

Locality and stratigraphy. Paleocene, Menat (see Materal and methods).

Diagnosis. This species is very distinct from the another subgener (M. bartenevi sp.n.) in the 
wider body, narrower antennae and much smaller antennomere 2 (pedicel), apparently narrower anterior edge of head and lack of median line on upper surface of head, shape of pronotum and its elytra less than twice as long as wide combined (while the elytra of $M$. bartenevi sp.n. are more than twice as long as wide combined).

Corrections to the description. Body length $9.1 \mathrm{~mm}$, head $1.3 \mathrm{~mm}$ long and $1.5 \mathrm{~mm}$ wide, body width $3.7 \mathrm{~mm}$. Surface of head without prominent upper tubercles, median part of frons and anterior part of occiput apparently elevated, at antennal insertions along posterior half of eyes and at temples with distinct grooves. Eyes particularly large, with diameter more than half of distance between eyes. Elytra with at least 10 (probably 11) long longitudinal rows of large and somewhat transverse cells, clearly raised veins $\mathrm{CuA}$ and $\mathrm{A} 1$ fusing together; intermediate vein between veins $\mathrm{M}$ and $\mathrm{CuA}$ (also joining with $\mathrm{CuA}$ and $\mathrm{A} 1$ ) and short anal vein at scutellum more or less distinct. Mesocoxae oval and subconjoining (wrongly drawn in original description). Metaventrite slightly longer than mesoventrite. Metepisterna about three times as long as wide. Metacoxae slightly oblique and only slightly longer than mesocoxae in mesal parts.

\section{Menatops bartenevi sp.n.}

Figs 165-168.

Holotype. "MNHN F.A. 57524" ("NEL 2947"). The print and counterprint of the holotype represent comparatively complete specimen (the print with traced most part of body, antennae, femora, pro- and mesotibiae, and also mesotarsus; the counterprint with exposed distal dart of body - pterothorax with elytra). The specimen has been collected by A. Nel in a new, small outcrop near the south-east of the village of Menat, rock comparatively smooth and becoming loose.

Locality and stratigraphy. Paleocene, Menat (see Materals and methods).

Etymology. The new species is named after Alexander F. Bartenev, professor in entomology and invertebrate zoology at Kharkov State (National) University, close friend of the first author from the student time, who recently passed away (end of November 2015).

Diagnosis. See the diagnosis of the preceding species.

Description. Body length (with elytra) 7.2 $\mathrm{mm}$, width apparently $2.1 \mathrm{~mm}$, elytral length 4.4 $\mathrm{mm}$. Body elongate; apparently slightly to moderately convex dorsally and subflattened ventrally. Integument of head and pronotum apparently with dense and coarse punctures; elytra with large suboval or subquadrate to somewhat subpolygonal cells arranged in at least 10 longitudinal rows between veins (and probably $11^{\text {th }}$ row externally from $\mathrm{Sc}$ ).

Head suboval and without traces of clear upper tubercles, suboval and nearly transverse, widest at extremely large eyes and apparently separated by half of transverse diameter of eye, temples gently narrowing posteriorly, antennal insertions apparently open. Mandibles and labrum not visible. Antennae comparatively short and rather thick; scape longest and rather thick; antennomere 2 (pedicel) subcylindrical, nearly as long as flagellomeres, markedly narrower than scape and slightly wider than flagellomeres; flagellomeres subequal in length and ultimate one acuminate. Prothorax moderately short; pronotum about one and 1/4 as wide as long, apparently slightly and gently convex, its sides seemingly widely (sub) explanate and slightly widening anteriorly, its sides rectilinear, anterior edge convex at the middle, anterior and posterior angles stump; prosternum before procoxae rather longer than procoxae, procoxae apparently narrowly separated. Mesoventrite markedly longer than prosternum. Mesocoxae moderately large and distance between them about $1 / 5$ of their diameter. Metaventrite very short. Metacoxae transverse, about three times as wide as long and their mesal parts moderately projecting posteriorly. Abdomenal ventrites 25 subequal in length, hypopygidium (ventrite 5) rounded to subangular at apex. Elytra slightly wider than prothorax, with very broadly arcuate sides, together more than twice as long as wide, steeply sloping along sides; with moderately expressed veins.

Femora comparable in shape and proportions, gently curved along anterior and posterior 
edges, about three times as long as wide. Tibiae apparently somewhat shorter than femora and very thin. Mesotarsus represented much longer than mesotibia.

\subsection{Genus Cupes Fabricius, 1801}

Type species Cupes capitatus Fabricius, 1801 , by monotypy, recent.

= Cupoides Motschulsky, 1856: 27 (type species Cupoides tesselatus Motschulsky, 1856, by monotypy, fossil);

= Tenomerga Neboiss, 1984: 448 (type species Cupes mucidus Chevrolat, 1829 , by original designation, recent);

=Distocupes Neboiss, 1984: 457 (type species Cupes varians Lea, 1902, by original designation, recent).

Composition. The genus includes 15 species from deposits beginning from the Paleocene and 16 species are known in the extant fauna (Neboiss, 1984; Ge, Yang, 2004). The fossil species are listed in Chapter 8 and in the catalogue by Kirejtshuk \& Ponomarenko (2016).

Diagnosis and comparison (after Ponomarenko, 1969; Neboiss, 1984; Kirejtshuk, 2005). It is necessary to note that, in addition to the notes in Kirejtshuk et al. (2010a), the species of this genus are characterized by the rather slender body with the subparallel-sided elytral edges, subvertically sloping elytral sides, the tuberous dorsal surface of the head with the strongly raised tubercles over each antennal insertions. Besides, the venation of elytra of Cupes species is represented by the strongly raised primary veins looking like ribs, which show a more or less clear difference in the level of development between the primary and secondary veins, and also cells between the veins are very large and subpolygonal (not transverse).

The genus Cupes can be easily diagnosed after the above key to genera and subgenera. The rather detailed diagnostics of the modern species of Cupes among modern representatives of other cupedines was published by Neboiss (1984). This genus is rather similar to the fossil groups of the subfamily with nine long longitudinal rows of cells on the long elytra, although, some modern representatives of Cupes, except the short prescutellar row of cells, have also a short row at base of the lateral edge of elytra (Neboiss, 1984). It is most similar and probably most closely related to Taxopsis gen.n., differing from the latter only in the characters listed in the mentioned key (body size, features of the prosternum, outline of the elytral cells). By its moderately long prosternum before the procoxae and the raised tubercles of the frons covering the narrowly separated antennal insertions Cupes can be distinguished from Cretomerga gen.n. and Furcicupes with the very short prosternum before the procoxae, from which it is also distinct in the moderately narrow neck (neck of Cretomerga gen.n. and Furcicupes is very narrow) and from the first, in addition, in the narrowly separated procoxae (procoxae of Cretomerga gen.n. are widely separated). The Cupes differs from the remainder extinct groups with nine rows of cells on elytra: - Apriacma gen.n. in the absence of Y-shaped depression on the head and the narrowly separated antennal insertions covered by the tubercles of the frons; - Miocupes Ponomarenko, 1973 in the longer and narrower head with the moderately narrow head and the moderately large eyes, the primary veins fused at elytral apices (primary veins of Miocupes are parallel along the entire length); - Cupopsis gen.n. in the moderately long head with the not large eyes and the absence of concavities along the anterior half of the inner edge of the eyes and the steeply (subvertically) sloping elytral sides; Latocupes in the more slender body, the narrowly antennal insertions covered by the tubercles of the frons (absence of Y-shaped depression), the usually narrower pronotum (less than twice as wide as long, although the pronotum of $C$. groehni Kirejtshuk, 2005 is as wide as in the species of Latocupes) and the elytra with the subvertically sloping sides, the strongly raised primary veins and the less transverse cells (less than twice as wide as long) on the elytra.

Another group of genera is united by the groups with 10 or 11 long longitudinal rows of cells on elytra [Chalepocarabus, Gracilicupes, Kirghizocupes, Menatops gen.n., Mesocupes s.lato, Paracupes s.lato (including Paracupoides subgen.n.) and Priacma]. However, Cupes, except the number of the long longitudinal rows of cells, differs from: 

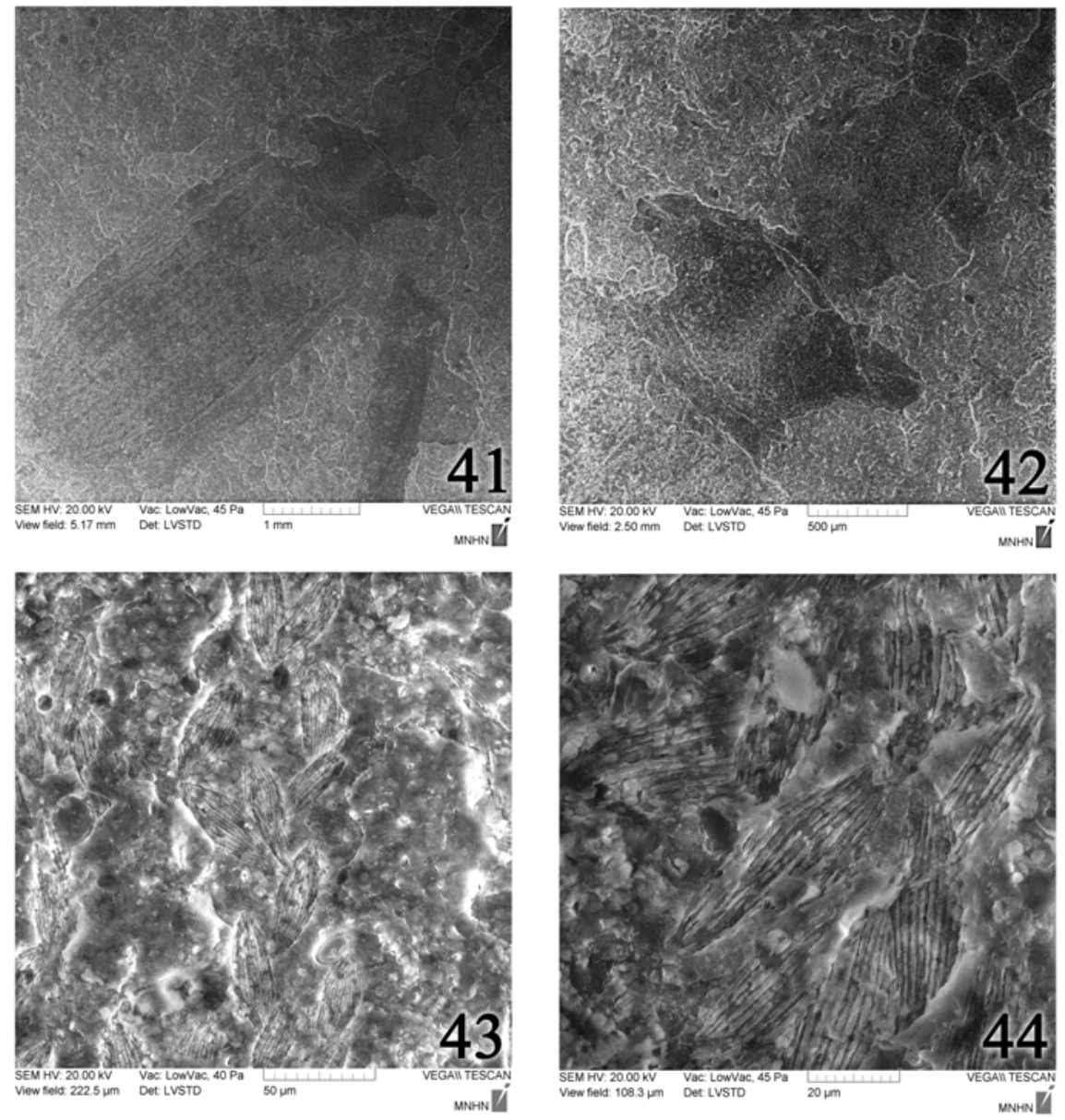

Figs 41-44. Cupes manifestus Kirejtshuk, Nel et Collomb, 2010 (holotype "MNT-06-902", print, micrograms, photographed under scanning electron microscope (SEM)); Paleogene, Paleocene; France, Menat: 41 body; 42 - head and prothoracic segment with appendages; 43 — scales on elytra; 44 - scales on pronotum. Length of specimen $6.1 \mathrm{~mm}$.

Рис. 41-44. Cupes manifestus Kirejtshuk, Nel et Collomb, 2010 (голотип "MNT-06-902", отпечаток, сфотографированный на растровом электронном микроскопе (SEM)); палеоген, палеоцен; Франция, Мена: 41 - тело; 42 - голова и переднегрудной сегмент с придатками; 43 - чешуйки на надкрыльях; 44 - чешуйки на переднеспинке. Длина экземпляра 6,1 мм.

- Chalepocarabus in the subparallel-sided body, the larger eyes, the transverse pronotum, the elytra with the well raised primary veins clearly fused at apex, subverticaly sloping sides and the dense cells in the long longitudinal rows;

- Gracilicupes in the markedly wider pronotum usually with the rectiliner sides (not arcuate) and the projecting anterior angles; the mod- erately large eyes (prothorax of Gracilicupes much narrower than its head with the very larger eyes), the longer prosternum, and the antennal insertions covered by the tubercles of the frons;

- Kirghizocupes in the not elongate head, the absence of Y-shaped depression on the frons, the narrowly separated antennal insertions covered by the tubercles of the frons and the pronotum markedly narrower than elytra; 
- Menatops gen.n. in the more slender body, the moderately long head with the moderately large eyes, only three long primary veins (A1, $\mathrm{CuA}$ and $\mathrm{M}$ ) expressed on the elytral disk (elytra of Menatops gen.n. with the clear R fusing A1), the antennal insertions covered by the tubercles of the frons;

-Mesocupes s.lato in the more slender body, the well raised primary veins of the elytra, the subverticaly sloping elytral sides and the narrowly separated antennal insertions covered by the tubercles of the frons, and in the clear fusion of the primary veins at elytral apices;

- Paracupes s.str. in the elytra with well raised primary veins, the subverticaly sloping sides, the simple lateral epipleural carina and the subacute apices, and also in the protibiae straight or slightly curved at apex;

- Paracupoides subgen.n. in the elytra with the subacute apices, the subparallel long anal veins (A1) and the elongate (lanceolate) scales on the dorsum, and also in the protibiae straight or slightly curved at apex;

- Priacma in the elytra with the well raised primary veins, the subverticaly sloping sides, the simple lateral epipleural carina and the subacute apices, the lack of preapical closing fold on the below side of the elytra, the narrowly separated gular sutures, the longer ventrite 1;

- Priacmopsis in the much smaller and slender body with the subparallel-sided elytra, the comparatively larger eyes, the longer metacoxae and the longer abdominal ventrite 1 .

Lastly the genus Cupes differs from Cupidium with unclear number of the long longitudinal rows of cells in the more slender body, the usually not arcuate pronotal sides and the longer prosternum before the procoxae and the conjointly subacute elytral apices.

Notes. All species of Cupes found in Menat are characterised by the rather wide anterior part of the head with only one pairs of the convexities covering the most length of their epicranium and separated only a very narrow median furrow, the very thick scapes, the not outlined tarsal grooves in the anterior part of their prosternum (if they are present at all) and the pronotum subrectilinearly widening anteri- ad. The studies of the specimens under electron microscope provided with a chance to observe scales on the elytral integument at least in two examined species.

Cupes manifestus Kirejtshuk, Nel et Colomb, 2010

Figs 41-44, 146, 147, 169-172. 218.

Cupes manifestus Kirejtshuk, Nel et Colomb, 2010:

Holotype. MNT-06-902-A and MNT-06902-B (MTM), print and counterprint. The specimen has been collected in a new, small outcrop near the south-east of the village of Menat, the rock comparatively hard and consistent.

Additional specimens. "MNHN.F.A. 52771" ("NEL 2144"), print and counterprint of an incomplete specimen showing very obliterated and unclear outlines of sclerites and deposited in the comparatively soft and fragile rock. Most details of this specimen are not traceable or missing. "MNHN.F.A.52770" ("NEL 801"), print with the incomplete specimen showing very obliterated and unclear outlines of sclerites and deposited in the comparatively soft and fragile rock. Most details of this specimen are also not traceable or missing, but five segments of the left antenna, the right anterior leg, the metacoxae and the posterior legs are visible. "MNHN F.A. 57525" ("NEL 1701"), print with incomplete specimen with unclear outlines of exposed sclerites is deposited in very hard rock. The specimen demonstrates the body with right antenna, subtriangular characteristic head, mesoand metacoxae, traces of profemora, intermediate and posterior legs. The additional specimens "MNHN.F.A.52771", "MNHN.F.A.52770" and "MNHN.F.A.57525" originated from a new, small outcrop near the south-east of the village of Menat. "MNHN F.A. 57526" ("Oli 186"), print with incomplete specimen with coarsely fragmented organic remains and unclear outlines of exposed sclerites is deposited in moderately hard rock. The specimen demonstrates the body with basal segments of both antennae, characteristic outline of the head, slightly visible prothorax with procoxae, pterothorax with metacoxae, traces of profemora and right protib- 
ia. "MNHN F.A. 57527” (“056”), print with incomplete specimen with clear outlines of exposed sclerites is deposited in soft rock. The specimen demonstrates the body with most segments of both antennae (preapical ones of left antennae are somewhat obliterated), characteristic outline of the head, obliterated place of rock with slightly visible outline of pronotum with clear sculpture, pterothorax with metacoxae, traces of all femora and protibiae. The specimens "MNHN F.A. 57526" and "MNHN F.A. 57527" have been collected by Philippe Olivier in the historical site of the ancient quarry of "Noir d'Auvergne" where Piton investigated in the years 1935-1940.

Notes. As the scales used in the original description of this species (Kirejtshuk, et al., 2010) were given wrong, the true measurements of the holotype body are actually as given in the corrections and addition to the redescription below. After an additional study, particularly using electron microscopy some characters in shape of the head and the pronotum were clarified.

Locality and stratigraphy. Paleocene, Menat (see Materials and methods).

Diagnosis. This new species can be easily diagnosed among the species from Menat after the below key to species. As all of them are rather similar, the diagnosis of $C$. distinctissimus sp.n. (see below) combining with the diagnosis published by Kirejtshuk et al. (2010) and this key can be used for a reliable diagnosis of the species under consideration.

Corrections and addition to the description of the holotype. Body $6.2 \mathrm{~mm}$ long, head $2.2 \mathrm{~mm}$ long and $2.5 \mathrm{~mm}$ wide, body width 2.8 $\mathrm{mm}$. Elytra with 9 rows of large polygonal cells. Dorsum covered with dense lanceolate scales, which are arranged in accordance with veins on elytra. Head with truncate anterior edge of frons, weak but clear tubercles over close antennal insertions, elongate paramedian convexities along frons and vertex and on each temple a characteristic and weakly raised tubercle clearly visible. Prosternum somewhat longer than mesoventrite and somewhat shorter than metaventrite.
Variations (additional specimens). "MNHN.F.A.52771": Body 5.6 mm long, head $1.7 \mathrm{~mm}$ long and $1.6 \mathrm{~mm}$ wide, body width 2.3 $\mathrm{mm}$. In spite of the fact that many structural features of the specimens examined are unclear, it can be visible that its temples are short and not prominent, and its pronotum is widening anteriad. Therefore, it fits Cupes manifestus better than other congeners from Menat, although the head of this specimen seems to have been somewhat turned and deformed. "MNHN.F.A. 52770": Body $7.8 \mathrm{~mm}$ long, head $1.3 \mathrm{~mm}$ long and $1.1 \mathrm{~mm}$ wide, body width $2.3 \mathrm{~mm}$. Many structural features of the specimens examined are unclear, although general outlines of visible sclerites are similar to those in C. manifestus better than other congeners from Menat. Nevertheless its comparatively short head with larger eyes and apparently arcuate pronotal sides are somewhat different from those in C. manifestus. "MNHN F.A. 57525": body $8.9 \mathrm{~mm}$ long without antenna and $2.0 \mathrm{~mm}$ wide. This specimen can be regarded as $C$. manifestus because of characteristic many proportions of the individual sclerites (particularly head and right antenna), although the general outline of its body is more slenger and elytra are subparallelsided. "MNHN F.A. 57526": $7.8 \mathrm{~mm}$ long without antennae. This specimen has hardly traceable most characters, but those of them, which are visible, more or less correspond to the typical characters of $C$. manifestus, but its general outlines of elytra look like somewhat more arcuate and temples of its head are not so prominent. “MNHN F.A. 57527": body $7.2 \mathrm{~mm}$ long without antenna. This specimen seems to have a most correspondence to the holotype.

\section{Cupes distinctissimus sp.n.}

Figs 45-56.

Holotype. "MNHN.F.A.51118", collected by A. Nel. The print and counterprint of the holotype is deposited in rather soft and fragile rock, and represented by the mixture of visible outlines from dorsal and ventral sclerites (the print with more exposed ventral sclerites and the counterprint with more exposed dorsal scler- 

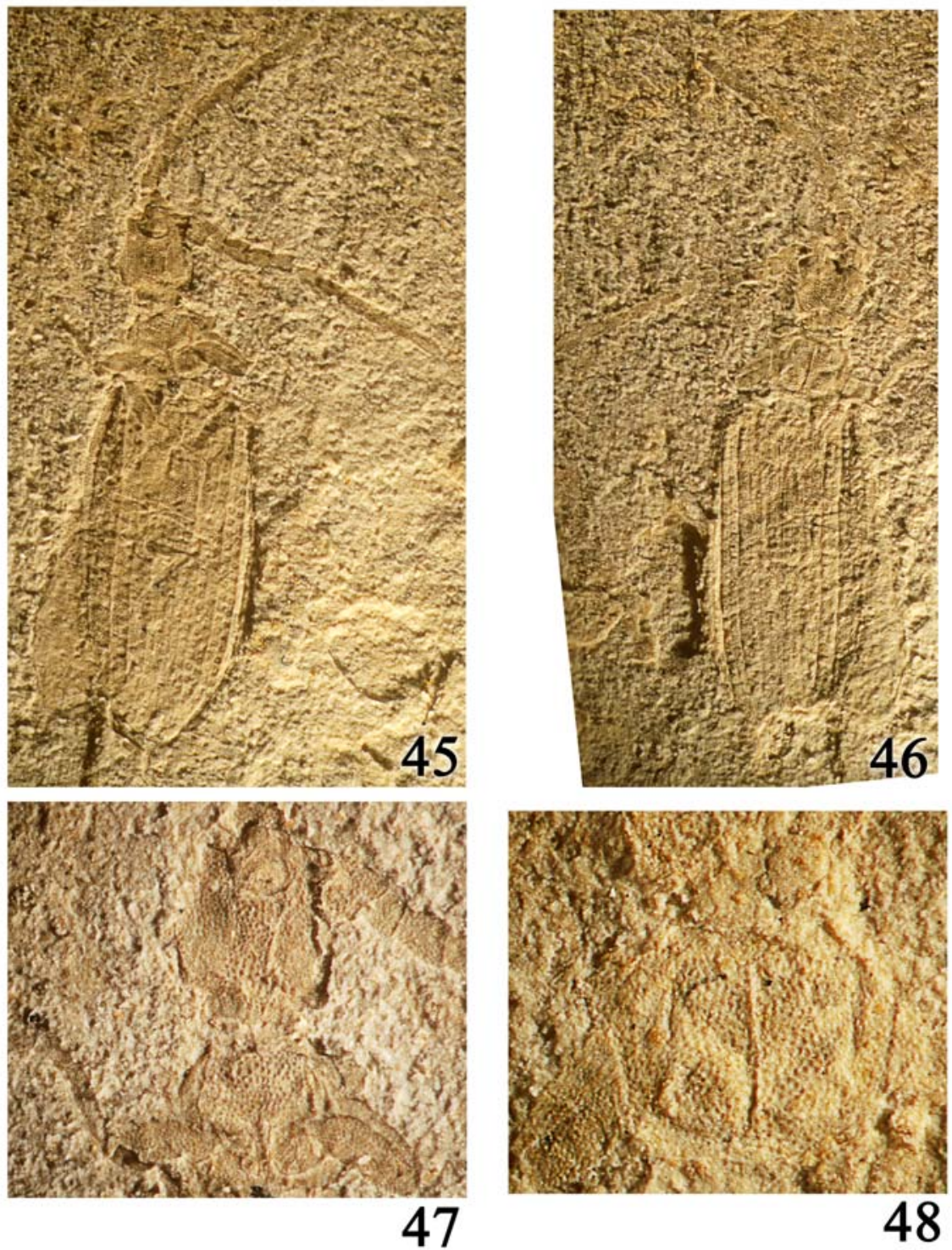

Figs 45-48. Cupes distintissimus sp.n. (holotype "MNHN.F.A.51118", dry print and counterprint, photographed under Olympus SCX9 with camera Olympus); Paleogene, Paleocene; France, Menat: $45-$ print, body; 46 - counterprint, body; 47 — print, head and prothorax with appendages; 48 - counterprint, pronotum. Length of specimen $7.3 \mathrm{~mm}$.

Pис. 45-48. Cupes distintissimus sp.n. (голотип “MNHN.F.A.51118”, сухие отпечаток и противоотпечаток, сфотографированные на микроскопе Olympus SCX9 с камерой Olympus); палеоген, палеоцен; Франция, Мена: 45 - тело отпечатка; 46 - тело противоотпечатка; 47 - голова и переднегрудь отпечатка с придатками; 48 - переднеспинка противоотпечатка. Длина экземпляра 7,3 мм.

ites), although the print shows some damage in the prothoracic segment and the counterprint is with missing posterior part of elytra, missing or unclear few antennomeres, two tibiae, many tarsomeres. The specimen has been collected by A. Nel in a new, small outcrop near the southeast of the village of Menat, in the rock comparatively smooth and becoming loose. 

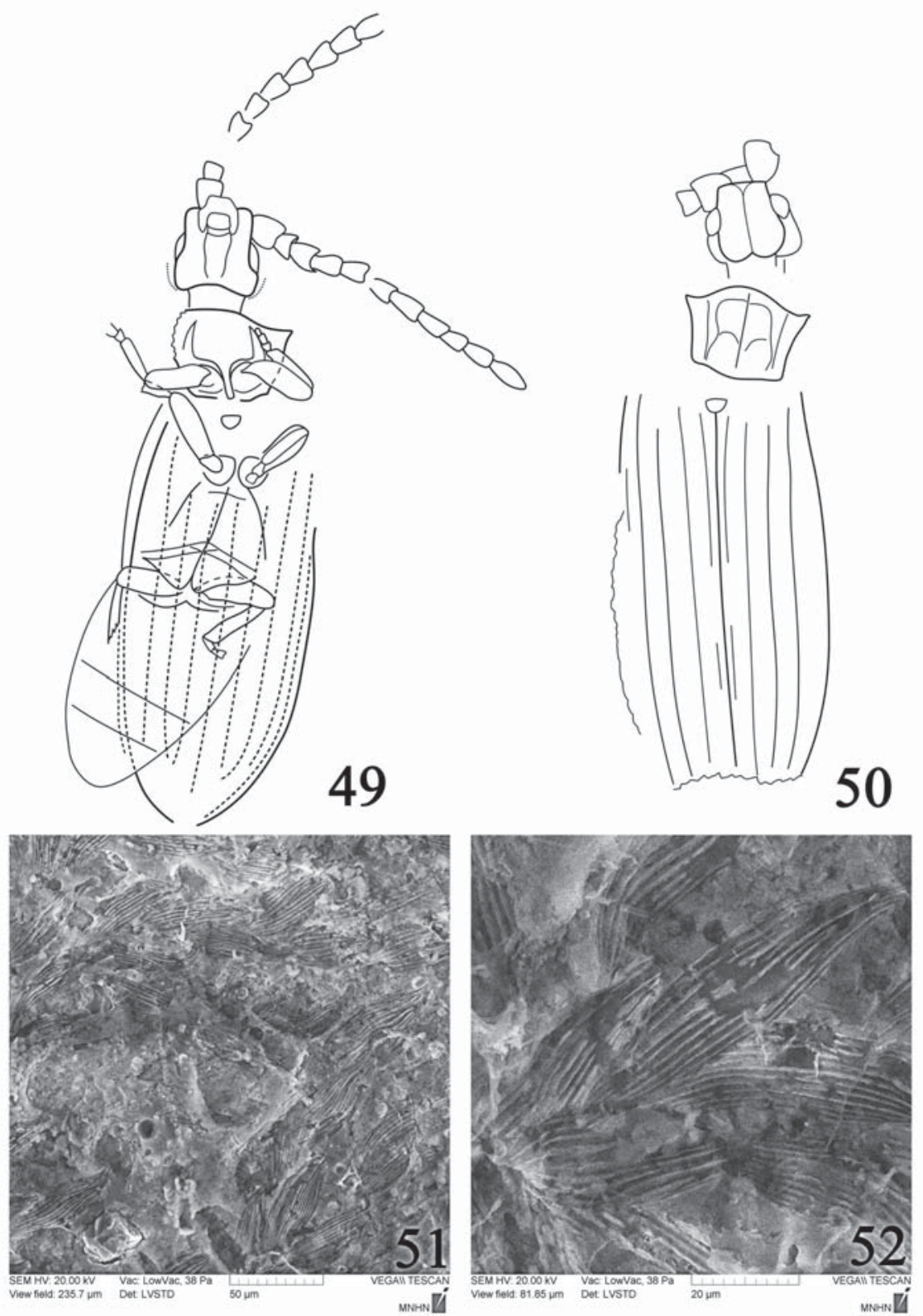

Figs 49-52. Cupes distintissimus sp.n. (holotype "MNHN.F.A.51118", print and counterprint); Paleogene, Paleocene; France, Menat: 49 - print, ventral, with broken line outlined sutural edges and primary veins of elytra, with dotted lines probable outlines of temples; 50 - counterprint, dorsal; 51 - print, micrograms of scales on elytra, photographed of print under scanning electron microscope (SEM); 52 - idem, with another magnification. Length of specimen $8.3 \mathrm{~mm}$.

Рис. 49-52. Cupes distintissimus sp.n. (голотип "MNHN.F.A.51118”, отпечаток и противоотпечаток); палеоген, палеоцен; Франция, Мена: 49 - отпечаток, снизу; прерывистой линией очерчены шовные края и первичные жилки надкрылий; пунктиром показаны вероятные очертания висков; 50 противоотпечаток, сверху; 51 - отпечаток, чешуйки надкрылий, сфотографированные на растровом электронном микроскопе (SEM); 52 - то же, при другом увеличении. Длина экземпляра 8,3 мм. 
Locality and stratigraphy. Paleocene, Menat (see Materals and methods).

Etymology. The epithet of this new species is the superlative of "distinctus" (separate, distinct; definite, lucid)

Diagnosis. This new species is easily diagnosed among the species from Menat after the below key to species. At the same time because these species are rather similar and probably closely related, the diagnosis of this new species can be used for other species from Menat. Cupes distinctissimus sp.n. demonstrates most similarity with fossil C. rohdendorfi IablokoffKhnzorian, 1960 differening from it in the longer head with only one pair of long convexities, the much smaller eyes, the shorter antennae with the thicker antennomeres. In addition to the characteristic tubercles (convexities) on the head, and also the strongly projecting and acute anterior angles of pronotum, this new species differs from other fossil congeners:

- C. eckfeldensis (Tröster, 1993), comb.n. in the subquadrangular head with the large scape and the subquadrangular prosternum;

- C. groehni Kirejtshuk, 2005 in the smaller eyes and the comparatively shorter antennae;

- C. hoffeinsorum Kirejtshuk, 2005 in the smaller eyes, the wider pronotum and the much more stout antennomeres;

- C. kerneggeri Kirejtshuk, 2005, C. komissari Kirejtshuk, 2005 and C. ponomarenkoi Kirejtshuk, Nel et Colomb, 2010 in the smaller eyes;

- C. tesselatus (Motschulsky, 1856) in the smaller eyes, the shorter antennae with the thicker antennomeres and the markedly narrower pronotum;

- C. weitschati Kirejtshuk, 2005 in the shorter antennae with the thicker antennomeres and the wider pronotum.

Cupes distinctissimus sp.n. is distinct from C. messelensis (Tröster, 1993), comb.n. represented only by the pterothorax, abdomen and elytra in the more widely rounded apex of the hypopygidium. This new species can be distinguished from C. praeglacialis Gersdorf, 1976 described with the rather short sharacteristics and bad pictures at least in the smaller body and the much thicker antennomeres. Finally, the new species under consideration differs from the modern members of the genus in the somewhat longer head with only one pair of paramedian convexities located along the most part of dorsal surface of the head and the more or less shorter antennae, the pronotum strongly widened anteriad and with the rather projecting and acuminate anterior angles.

Description. Body length (with elytra) 8.3 $\mathrm{mm}$, width apparently $2.5 \mathrm{~mm}$, head $1.2 \mathrm{~mm}$ long and $1.4 \mathrm{~mm}$ wide, elytral length $5.6 \mathrm{~mm}$. Body elongate; apparently moderately to rather convex dorsally and subflattened ventrally. Integument of head and pronotum with moderately large regular punctures separated by much less than one puncture diameter or less; lower surface of head and prosternum with somewhat larger and shallower punctures; pterothoracic ventral sclerites and abbomen with somewhat finer and rather dense punctures; elytra with large subpolygonal cells arranged in apparently nine rows between veins. Dorsum covered with dense lanceolate scales, which are arranged in accordance with veins on elytra.

Head subquadrangular, with only clear tubercles at antennal insertions, somewhat longer than wide, apparently widest at subangular temples, with moderately large oval eyes (moderately wide dorsally and rather narrow ventrally), their elongate diameter nearly as great as length of frons before eyes and somewhat less than length of temples; gular sutures moderately separated. Mandibles not visible. Mentum moderately small, subquadrangular and transverse. Antennae comparatively short; scape about as long as flagellomeres and almost twice longer than antennomere 2 (pedicel); scape rather swollen, somewhat wider than pedicel and basal flagellomeres, other flagellomeres gradually becoming narrower to ultimate flagellomere with pointed apex. Prothorax subtrapezoid and moderately short; pronotum about 1.5 times as wide as long and markedly wider than head; apparently slightly and gently convex, its sides seemingly widely (sub) explanate and widening anteriorly in S-curve, its sides shallowly emarginate, anterior edge subbi-sinuate, anterior and 

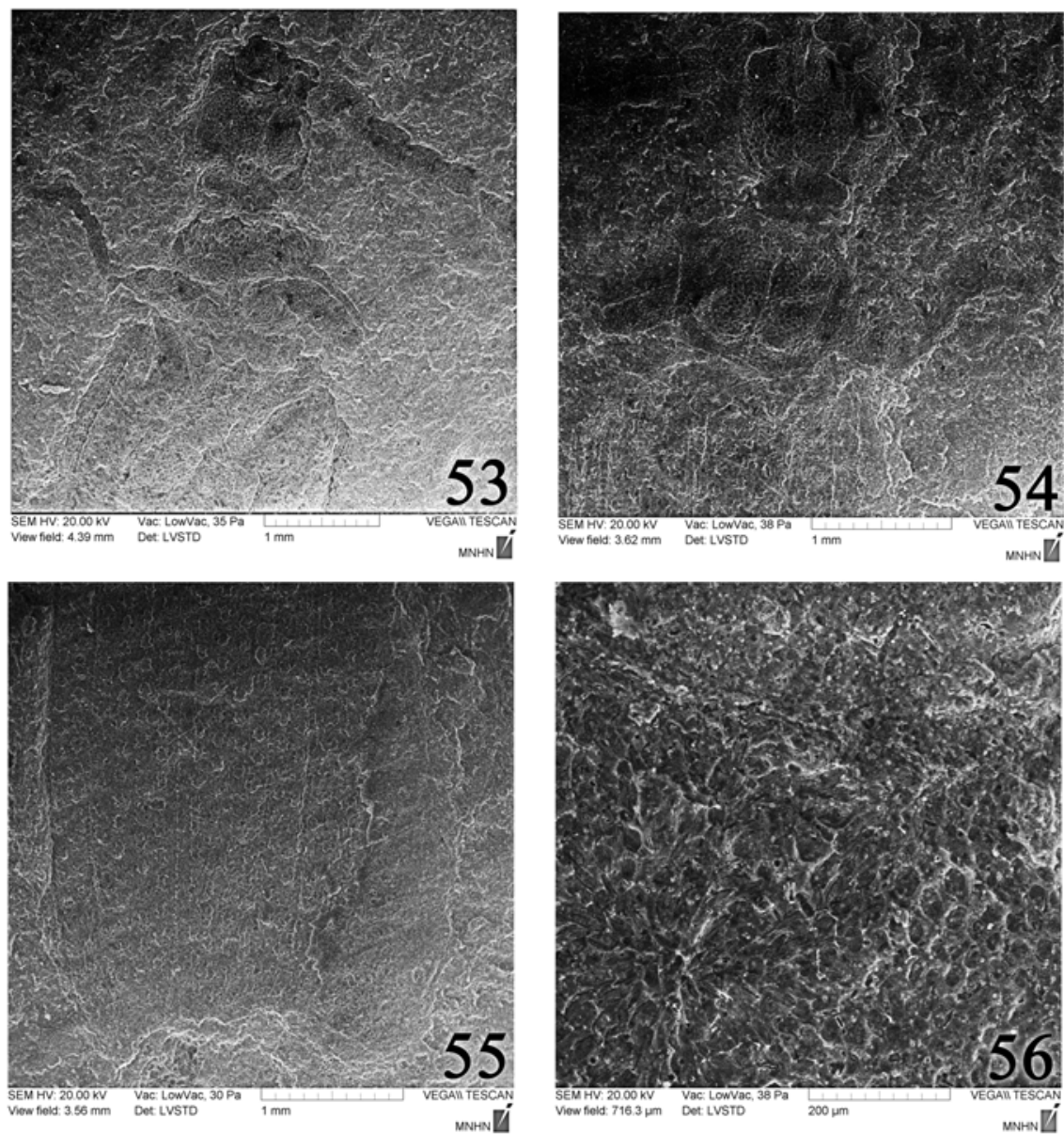

Figs 53-56. Cupes distintissimus sp.n. (holotype "MNHN.F.A.51118", print and counterprint, micrograms under scanning electron microscope (SEM)); Paleogene, Paleocene; France, Menat: 53 - print, anterior part of head; 54 - counterprint, head and pronotum; 55 - counterprint, distal part of elytra; 56 - counterprint, integument on pronotum. Length of specimen $8.3 \mathrm{~mm}$.

Рис. 53-56. Cupes distintissimus sp.n. (голотип "MNHN.F.A.51118”, отпечаток и противоотпечаток, сфотографированные на растровом электронном микроскопе (SEM)); палеоген, палеоцен; Франция, Мена: 53 - передняя часть головы отпечатка; 54 - голова и переднеспинка противоотпечатка; 55 дистальная часть надкрылий противоотпечатка; 56, поверхность переднеспинки противоотпечатка. Длина экземпляра 8,3 мм.

posterior angles with distinct top, anterior ones rather projecting, its disk with median carina and narrow furrow along lateral edge, interspace between carina and furrow rather swollen; prosternum before procoxae about 1.5 times as long as procoxae and probably slightly depressed along propleura (but without tarsal groove along anterior edge); procoxae apparently narrowly separated. Mesoventrite appar- ently about as long as prosternum before procoxae and somewhat shorter than metaventrite. Mesocoxae moderately large and distance between them extremely narrow. Metaventrite about $2 / 3$ as long as wide at base. Metacoxae medially projecting anteriad, somewhat wider than long and their mesal parts moderately projecting posteriorly. Abdomen with visible boundaries between last three ventrites (without trace 
of overlapping); hypopygidium about 1.5 times as long as ventrite 4 and rounded at apex. Elytra slightly wider than prothorax, with slightly arcuate sides, slightly more than twice twice as long as wide combined, apparently moderately convex; with well expressed main veins and clear conjoining of $\mathrm{CuA}$ and $\mathrm{A} 1$.

Femora comparable in shape and proportions, gently curved along anterior and posterior edges, about 2.5 times as long as wide. Tibiae apparently somewhat shorter than femora and moderately thin. Tarsi represented by moderately wide and somewhat lobed basal tarsomeres.

\section{Cupes simillimus sp.n.}

Figs 57-67.

Holotype. "MNHN.F.A5 1120", collected by A. Nel, print and counterprint. The holotype is deposited in very hard rock and represented by the somewhat obliterated outlines of sclerites, its counterprint is with missing posterior part of body, most antennomeres, two femora, four tibiae, many tarsomeres. The specimen has been collected by A. Nel in a new, small outcrop near the south-east of the village of Menat. The rock is rather smooth.

Locality and stratigraphy. Paleocene, Menat (see Materals and methods).

Etymology. The epithet of this new species is the superlative of "similis" (like, similar, resembling).

Diagnosis. This new species is easily diagnosed among the species from Menat after the below key to species. As all of them are rather similar, the diagnosis of $C$. distinctissimus sp.n. (see below) combining with this key can be used for a reliable diagnosis of the species under consideration.

Description. Body length (with elytra) 6.8 $\mathrm{mm}$, width apparently $2.0 \mathrm{~mm}$, head $1.6 \mathrm{~mm}$ long and $1.2 \mathrm{~mm}$ wide, elytral length $4.6 \mathrm{~mm}$. Body elongate; apparently moderately to rather convex dorsally and subflattened ventrally. Integument of head and pronotum with comparatively large regular punctures separated by much less than one puncture diameter or less; pterotho- racic ventral sclerites and abbomen with somewhat larger punctures; elytra with large subpolygonal cells arranged in nine rows between veins. Dorsum without lanceolate scales visible under electronic microscope.

Head suboval and widest at arcuate temples, with only clear tubercles at antennal insertions and apparently on temples, about as long as wide, with moderately large oval eyes moderately wide and strongly close to anterior edge of frons. Mandibles not visible. Mentum moderately small, subquadrangular and transverse. Antennae represented by only scapes (rather thick and slightly longer than wide). Prothorax subtrapezoid and moderately short; pronotum about 1.5 times as wide as long and markedly wider than head; apparently slightly and gently convex, its sides seemingly widely (sub) explanate and rectilinearly widening anteriorly, its sides shallowly emarginate, anterior edge subbi-sinuate, anterior and posterior angles with distinct top, anterior ones rather projecting, its disk with median carina and narrow furrow along lateral edge, interspace between carina and furrow rather swollen; prosternum before procoxae apparently 1.5 times as long as procoxae. Mesoventrite looking like very short (probably as sequence of peculiar fossilization). Mesocoxae moderately large and distance between them extremely narrow. Metaventrite apparently twice longer than prosternum before procoxae and about $2 / 3$ as long as wide at base. Metacoxae transverse, about 1.5 times as wide as long and their mesal parts moderately projecting posteriorly. Abdomen with long overlapping, ventrite 1 somewhat longer than each of ventrites 2-5, which are subequal in length; hypopygidium rounded at apex. Elytra slightly wider than prothorax, nearly subparallel-sided, slightly more than twice as long as wide combined, apparently moderately convex; with well expressed main veins.

Femora comparable in shape and proportions, gently curved along anterior and posterior edges, about three times as long as wide. Tibiae apparently somewhat shorter than femora and moderately thin. Tarsi represented by remains of one rather narrow mesotarsus. 

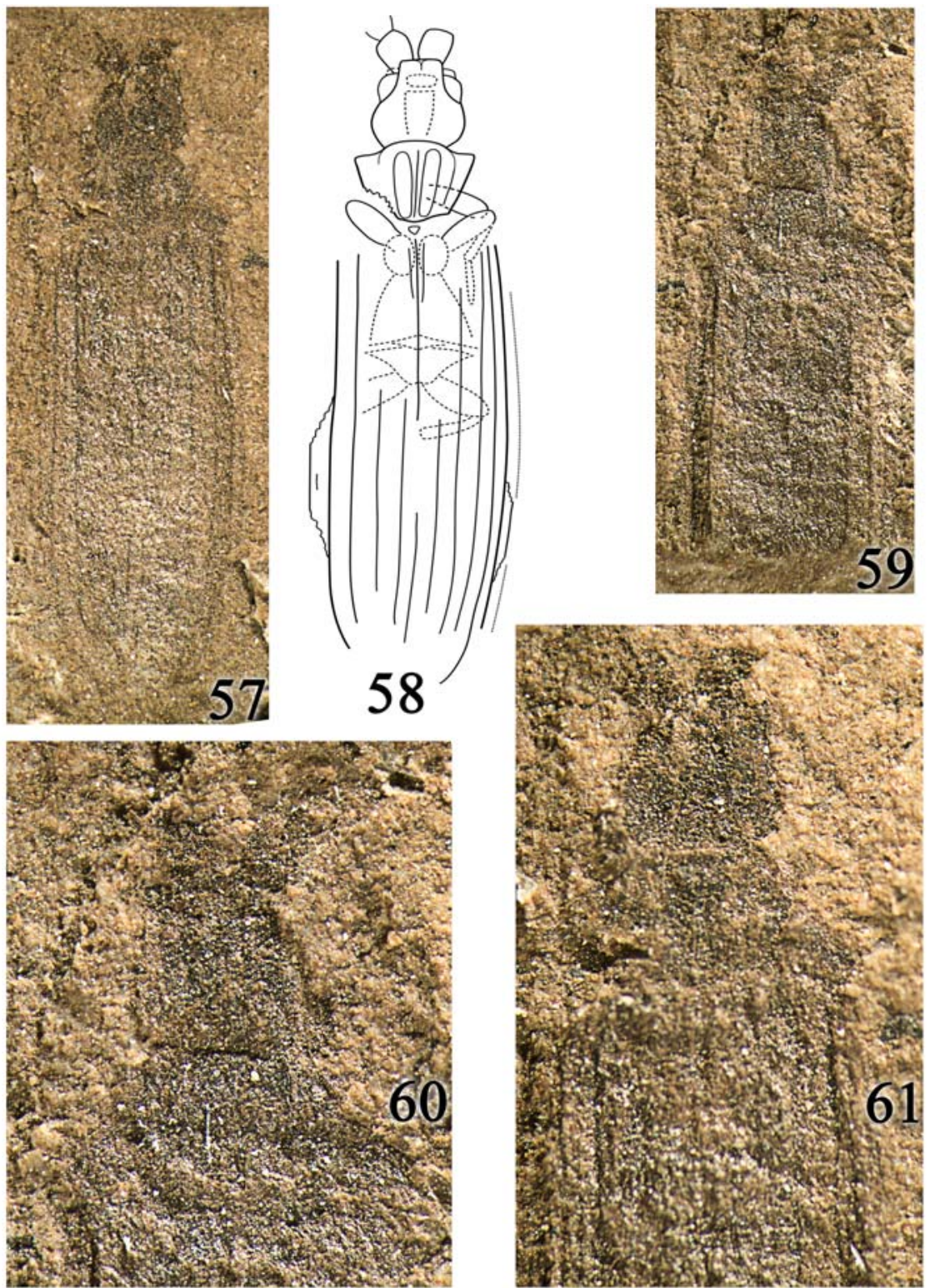

Figs 57-61. Cupes similliimus sp.n. (holotype "MNHN.F.A5 1120", print and counterprint, photographed under Olympus SCX9 with camera Olympus); Paleogene, Paleocene; France, Menat: 57 — print, body; 58 - print, body, dorsal, with broken outlines of ventral sclerites head and thorax; 59 - counterprint, body; 60 - counterprint, head and prothorax; 61 - print, anterior part of body. Length of specimen $6.8 \mathrm{~mm}$. Рис. 57-61. Cupes similliimus sp.n. (голотип "MNHN.F.A5 1120", отпечаток и противоотпечаток, сфотографированные на мироскопе Olympus SCX9 с камерой Olympus); палеоген, палеоцен; Франция, Мена: 57 - тело отпечатка; 58 - тело отпечатка, сверху; прерывистой линией очерчены нижние склериты головы и груди; 59 - тело противоотпечатка; 60 - голова и переднегрудь противоотпечатка; 61 - передняя часть тела отпечатка. Длина экземпляра 6,8 мм. 

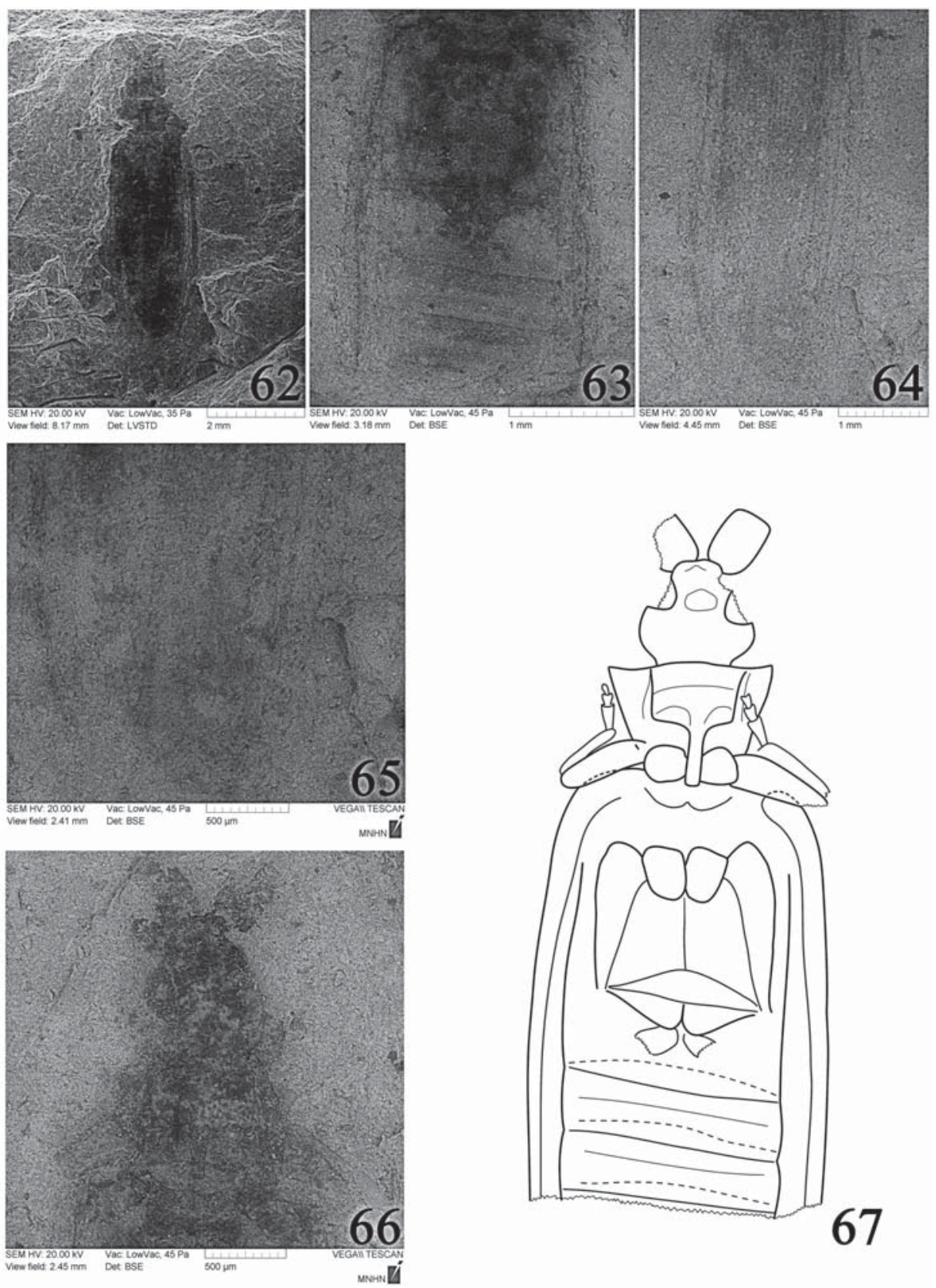

Figs 62-67. Cupes simillimus sp.n. [holotype "MNHN.F.A5 1120", print and counterprint, micrograms, photographed under scanning electron microscope (SEM)]; Paleogene, Paleocene; France, Menat: 62 print, body; 63 - counterprint, metaventrite and base of abdomen; 64 - print, elytra; 65 - print, elytral apices; 66 - counterprint, head and prothorax; 67 - counterprint, body, ventral. Length of specimen $6.8 \mathrm{~mm}$. Рис. 62-67. Cupes simillimus sp.n. [голотип "MNHN.F.A5 1120", отпечаток и противоотпечаток, сфотографированные на растровом электронном микроскопе (SEM)]; палеоген, палеоцен; Франция, Мена: 62 - тело отпечатка; 63 - метавентрит и основание брюшка противоотпечатка; 64 надкрылья отпечатка; 65 - вершины надкрылий отпечатка; 66 - голова и переднегрудь противоотпечатка; 67 - тело противоотпечатка, снизу. Длина экземпляра 6,8 мм. 


\subsection{Key to species of Cupes from Menat}

1. Head subquadrangular and with subangular temples; anterior edge of frons at distance from anterior edge of eyes nearly subequal to elongate diameter of eyes; pedicel and basal flagellomeres only slightly narrower than scape; elytra with gently arcuate sides; body length ca. $8.3 \mathrm{~mm}$. Figs $45-56$ C. distinctissimus sp.n.

- Head suboval and with rounded temples; combination of remaining characters other. ... 2

2. Eyes with usual distance from anterior edge of frons; head widest at eyes; temples only slightly longer than eyes; elytra with gently arcuate sides; body length ca. 5.6-8.9 mm. Figs 41-44, 169172 .

C. manifestus Kirejtshuk, Nel et Colomb, 2010

- Eyes very close to anterior edge of frons; head widest at rounded temples; temples about twice as long as head; elytra with subparallel lateral edges; body length ca. $6.8 \mathrm{~mm}$. Figs $57-67 \ldots$. .. . simillimus sp.n.

\subsection{Genus incertus sp.1}

Figs 142-144.

Specimen examined. MNHN "R 63906", print. The specimen includes the badly preserved and somewhat charry coleopterous remains, rather fragile and unclear; almost complete body have no traces of outlines of thoracic sclerites, and its appendages are represented by fragments of anterior legs, feeble contour of one middle femur, one antenna with seven antennomeres and another with six antennomeres. This piece of rock is comparatively smooth and slightly becoming loose.

Locality and stratigraphy. Paleocene, Menat (see Materals and methods).

Notes. Body length (with elytra) $12.6 \mathrm{~mm}$, width $4.4 \mathrm{~mm}$. The outlines of the accessible structures (shape of head, pronotum, elytra). The small pronotum of this species has a typical outline for many cupedines, however its proportion to other sclerites is similar to that in the Cretaceous Gracilicupes, it cannot be put in this taxon because of different shape of its head and pronotum. The elytra look like having gently sloping sides with (sub) explanate edges (as in Mesocupes), however it is impossible to associate this species with members of this genus because of the very small pronotum. If it is possible to admit that the elytra of the specimen examined were spread as a result of fossilization, this form could be an aberrant member of the Cupes taking into consideration some external similatity with C. manifestus. Nevertheless, at the moment this species can be scarcely linked with any group of the subfamily, but it could have some relation with the two following specimens remained without generic and species attribution.

\subsection{Genus incertus sp.2.}

Fig. 149-150.

Specimens examined. "MNHN.F.A.52794" ("NEL 2293"), print and counterprint with the incomplete specimen showing rather obliterated and unclear outlines, deposited in the comparatively soft and fragile rock. It originated from a new, small outcrop near the south-east of the village of Menat.

Locality and stratigraphy. Paleocene, Menat (see Materals and methods).

Notes. Body $14.4 \mathrm{~mm}$ long, head $2.4 \mathrm{~mm}$ long and elytra $11.3 \mathrm{~mm}$ long. This specimen is characterised by the rather slender body, the narrow pronotum (narrower than head), the very large eyes, the very dense and fine sculpture on the underside, the elytra with apparently nine longitudinal rows of transverse or subpolygonal cells, not clear primary veins and the subvertically sloping sides which are somewhat (sub) explanate along the lateral edges. Its head seems to be compressed and additionally spread because a feeble Y-shaped dorsal carina on its dorsal surface is shifted aside. As a result, the head demonstrates very large eyes which are difficult to interprete. Thus this specimen could belong to a separate genus which is impossible to define in the terms comparable with those used for other generic taxa of the subfamily.

\subsection{Genus incertus sp.3.}

Fig. 151-152.

Specimen examined. "MNHN.F.A.52772" ("NEL 786"), print and counterprint with the 
incomplete specimen showing rather smoothed and unclear outlines, deposited in the comparatively soft and fragile rock. It originated from a new, small outcrop near the south-east of the village of Menat.

Locality and stratigraphy. Paleocene, Menat (see Materals and methods).

Notes. Body $13.2 \mathrm{~mm}$ long, head $2.0 \mathrm{~mm}$ long and $1.8 \mathrm{~mm}$ wide, body width $3.5 \mathrm{~mm}$, length of elytra $9.8 \mathrm{~mm}$. The head seems to have been deformed because the eyes look like shifted; posterior part of head with traces of the paramedian convexities. Many characters of this specimen are somewhat similar to those of Mesocupes species from Menat, including the transverse cells in the longitudinal rows of the elytra. However the specimen under consideration is smaller and has the narrow pronotum and the gular sutures divergent in both anterior and posterior parts. Nevertheless, the set of accessible characters in it could not be used for both generic and species diagnostics.

\subsection{Genus incertus sp.4.}

Fig. 173-174.

Specimens examined. "MNHN.F.A.57529” ("Oli 137"), print of separate elytron with well preserved chitin remains and clear traces of imprinted venation and sculpture, deposited in the moderately soft and fragile rock. "MNHN. F.A.57530" ("Oli 856"), print of separate elytron with few remains of chitin and rather obliterated traces of imprinted of venation and sculpture, deposited in the moderately soft and fragile rock. The specimens have been collected by Philippe Olivier in the historical site of the ancient quarry of "Noir d'Auvergne" where Piton investigated in the years 1935-1940.

Locality and stratigraphy. Paleocene, Menat (see Materals and methods).

Notes. The separate elytra of "MNHN.F.A. 57529" with length $5.9 \mathrm{~mm}$ and "MNHN.F.A. 57530 " with length $6.2 \mathrm{~mm}$ could belong to the same genus and probably to the same species. They also have significant similarity with those in the modern Priacma and Paracupes in the comparatively weak primary veins, 10 longitu- dinal rows of cells, gentle sloping of elytral sides and their blunt apices. Nevertheless the disposition of veins and longitudinal rows of cells are different from those in both mentioned taxa. It seems to be better to leave them without naming till new materials from Menat will be found and studied.

\section{New genera and species of Cupedinae}

\subsection{Apriacma gen.n.}

Figs 73-75.

Type species. Priacma tuberculosa Tan, Ren et Shin, 2006, fossil.

Etymology. The name of this new genus is formed from Greek negative prefix " $a$ " and generic name "Priacma". Gender feminine.

Composition. Four species previously described from the early Cretaceous (Tan, Ren et Shin, 2006) as members of Priacma: A. clavata (Tan, Ren et Shin, 2006), comb.n., A renaria (Tan, Ren et Shin, 2006), comb.n., A. tuberculosa comb.n., and (?) A. latidentata (Tan, Ren et Shin, 2006), comb.n.

Specimens examined. Holotype of Priacma clavata "CNU-C-LB2006001"; holotype of $P$. renaria "CNU-C-LB2006002"; holotype of P. tuberculosa; "CNU-C-LB2005011"; holotype of P. latidentata "CNU-C-LB2005010".

Locality and stratigraphy. All congeners originated from Yixian; Beipiao City, Chaomidian village, Liaoning Province, China; Early Cretaceous, Barremian-Aptian, Yixian Formation.

Diagnosis. Body elongate of medium size $(9.5-12.3 \mathrm{~mm})$. Integument with moderately coarse sculpture and punctation; large subquadrangular(transverse) to polygonal cells of elytra arranged into nine long longitudinal rows and a short prescutellar row interspaced by weak secondary and more raised primary veins; A1 straight, almost reaching elytral apex and fusing with $\mathrm{CuA}$ before apex. Head usually subtriangular, with rather narrow neck (3/4-3/5 as wide as head at temples), with more or less expressed $\mathrm{Y}$ - or V-shaped depression, well projecting temples; dorsal surface with weakly raised tuber- 

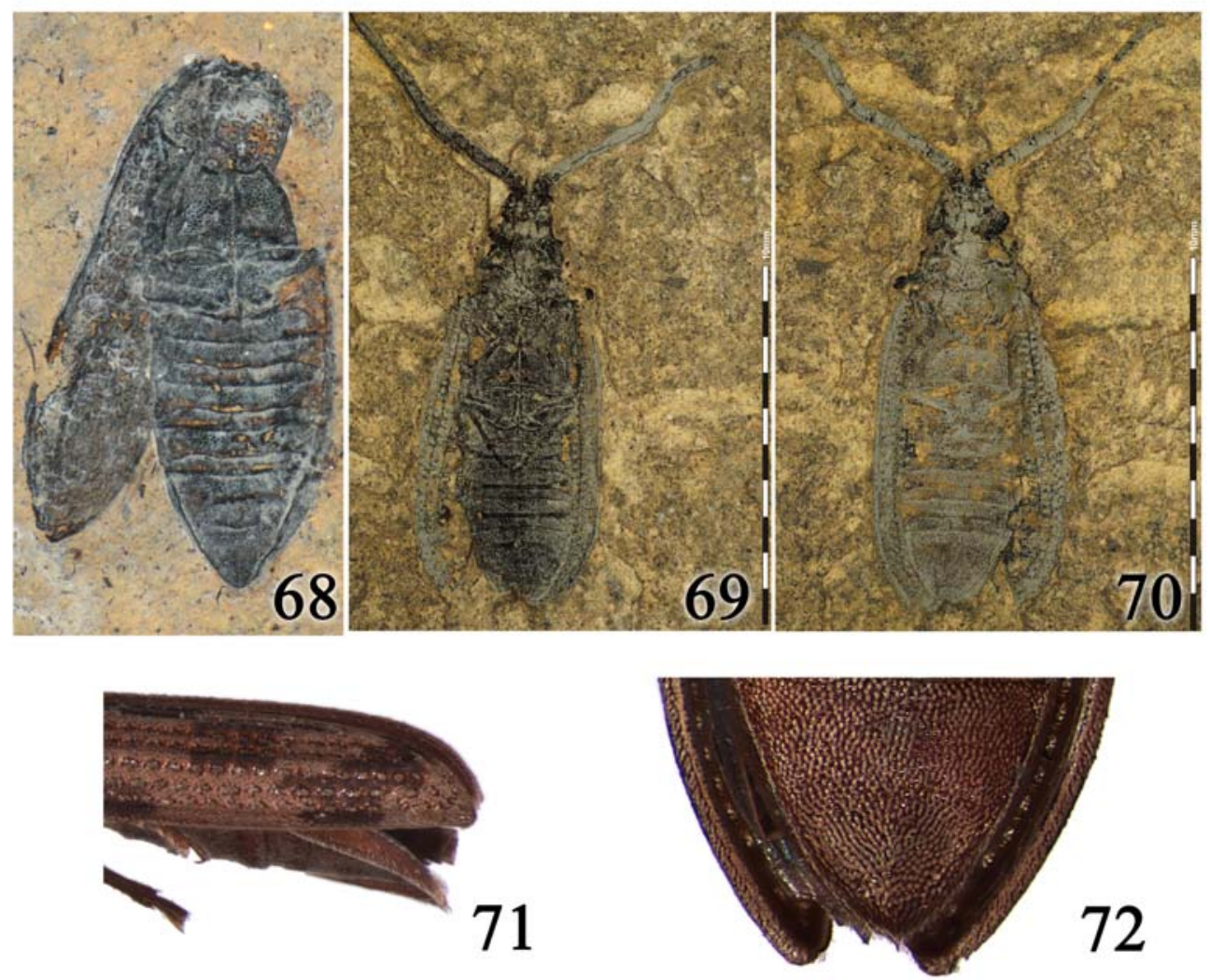

Figs 68-72. Species of of the genus Cupes (photos from S. Wedmann (SFNFM) and H. Lutz (LNNR)): 68 C. messelensis (Troester, 1993), comb.n., holotype (SFNFM "MeI 2806"); Paleogene, Middle Eocene; Germany, Messel; length of specimen $6.0 \mathrm{~mm}$; 69-70 - C. eckfeldensis (Troester, 1993), comb.n., holotype (LNNR “1992/461"); Paleogene, Middle Eocene; Germany, Eckfelder Maar, print and counterprint, length of specimen $8.8 \mathrm{~mm}$; $71-$ C. concolor Westwood, 1835; recent; posterior part of body, lateral (ZIN, "Am. Sept."), length of specimen $9.5 \mathrm{~mm} ; 72$ - idem, abdomen, ventral.

Рис. 68-72. Виды роды Cupes (фотографии от С. Ведманн (S. Wedmann, SFNFM) и Г. Луца (H. Lutz, LNNR)): 68 - C. messelensis (Troester, 1993), comb.n., голотип (SFNFM “MeI 2806"); палеоген, средний эоцен; Германия, Мессель; длина экземпляра 6,0 мм; 69-70-C. eckfeldensis (Troester, 1993), comb.n., голотип (LNNR “1992/461”); палеоген, средний эоцен; Германия, Экфельд; отпечаток и противоотпечаток; длина экземпляра 8,8 мм; $71-$ C. concolor Westwood, 1835; современный; задняя часть тела, сбоку (ZIN, “Am. Sept.”), длина экземпляра 9,5 мм; 72 - то же, брюшко, снизу.

Рис. 73-76. Ископаемые виды сем. Cupedidae: 73 - Apriacma tuberculosa (Tan, Ren et Shih, 2006), comb.n., голотип (“CNU-C-LB 2005011”, отпечаток, сфотографированный на микроскопе Leica MZ 12.5 с камерой Nikon Digital Camera DXM1200C); нижний мел, формация исянь; Китай, Ляонинь, Исянь; тело сухого отпечатка; 74 - то же, тело; прерывистой линией очерчены вентральные склериты головы, груди и брюшка; пунктиром прослеживающиеся очертания верхних структур головы (бугорки) и переднеспинки (медиальное вздутие и отогнутые края); 75 - то же, тело отпечатка под спиртом; длина экземпляра 9,8 мм; 76 - Cainocups aixensis sp.n., голотип (MNHN “Aix 18”, сфотографированный на микроскопе Olympus SCX9 с камерой Olympus); палеоген, верхний олигоцен; Франция, Жа-де-Буффан, Экс-ан-Прованс; дистальная часть надкрылья; длина отпечатка 6,3 мм. 

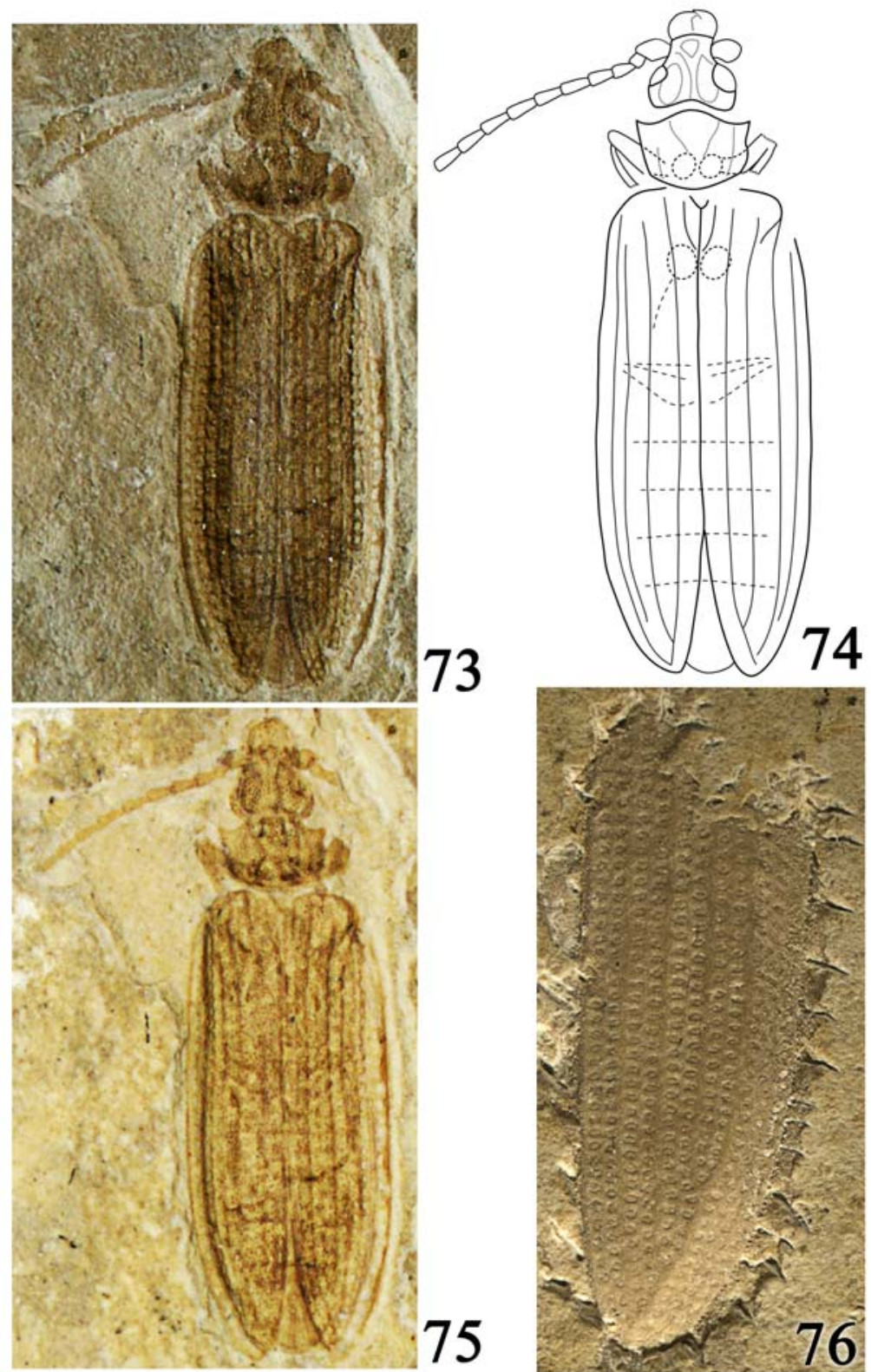

Figs 73-76. Fossil species of the family Cupedidae: 73 - Apriacma tuberculosa (Tan, Ren et Shih, 2006), comb.n., holotype (“CNU-C-LB 2005011", print, photographed under Leica MZ 12.5 with camera Nikon Digital Camera DXM1200C); Lower Cretaceous, Yixian Formation; China, Liaoning, Beipiao; body on dry print; 74 - idem, body with broken outlines of ventral sclerites head, thorax and abdomen; and dotted line traced outlines of dorsal structures of head (tubercles) and pronotum (median convexity and explanate sides); 75 - idem, body on print with alcohol; length of specimen $9.8 \mathrm{~mm} ; 76$ - Cainocups aixensis sp.n., holotype (MNHN “Aix 18”, photographed under Olympus SCX9 with camera Olympus); Paleogene, latest Oligocene; France, Jas de Bouffan, town Aix-en-Provence; distal part of elytron; length of print $6.3 \mathrm{~mm}$. 
cles (paramedian longitudinal convexities along eye edge to temples), antennal insertions moderately widely separated and apparently not covered by tubercles. Mandibles rather strong and arcuately curved at outer edge before stout bidentate apex. Antennae subfiliform and moderately long; antennomere 1 (scape) subequal in length with flagellomeres or slightly longer than antennomere 2 (pedicel) and more or less thicker. Pronotum subtrapezoid and rectilinearly widening anteriad, with widely explanate sides, projecting and subacute anterior angles, usually tuberculate surface and weak median elevated stripe. Part of prosternum before procoxae markedly longer than procoxae. Elytra 2.2-2.5 times as long as wide combined, with subrectiliner lateral edges, subrounded to subacute apices and apparently steeply (subvertically) sloping sides. Abdominal ventrites articulated without clear overlapping, ventrite 1 subequal to clearly longer than each of ventrites 2-4 and hypopygidium about as long as ventrite 1 or longer and rounded at apex. Legs moderately thin, frequently comparatively long; with protibia straight and narrow tarsi. Aedeagus of cupedidtype, rather long and with wide flattened parameres.

Comparison. This new genus is rather similar to the recent members of the genera similar and apparently closely related to Cupes with nine long longitudinal rows of cells on elytra. The main important characters to distinguish it among the forms with the slender body having such number of rows of cells and expressed primary veins of elytra (Adinolepis, Ascioplaga, Cupes, Cupopsis gen.n., Prolixocupes, Rhipsideigma, etc.) are the clear $\mathrm{Y}$ - or $\mathrm{V}$-shaped depression on the frons, and this characters have also the slender species of Cretomerga gen.n. and Furcicupes, although Apriacma gen.n. differs from them in the longer prosternum before the procoxae. The new genus under consideration differs from Kirghizocupes with the Yshaped depression on the head and 10 (or 11) long longitudinal rows of cells on elytra not only in the number of these long rows of cells, but also in the shorter head and pronotum widening anteriorly. Apriacma gen.n. differs from Taxop- sis gen.n. in the not transverse or slightly transverse cells in the long rows on the elytra, smaller and the more slender body with the narrower metaventrite, the clear Y- or V-shaped depression on the frons and the narrower tarsi. It differs from Latocupes in the much more slender body with the subparallel-sided elytra having the steeply (subvertically) sloping sides and the more raised primary veins. From other genera with 10 or more long longitudinal rows of cells on the elytra (Cainomerga subgen.n., Gracilicupes, Menatops gen.n., Mesocupes s.lato, Paracupes s.str., Paracupoides subgen.n., Priacma, and Latocupes) Apriacma gen.n. differs not only in the number of the rows of cells, but also in the clear Y- or V-shaped depression (although subgenus Anaglyphites stat.n. also demonstrates a more or less expressed Y- or V-shaped depression on the frons) and the pronotum strongly and subrectilinearly widening anteriad. Besides, it also differs from Gracilicupes in the smaller eyes, the wider pronotum with the sides widening anteriad and with the prominent anterior angles (not with arcuate sides narrowing both anteriad and posteriad) and the Cupes-type of aedeagus. It differs from Anaglyphites stat.n. and Mesocupes s.str. in the slender body, the subrectilinear elytral sides, the well expressed primary veins with the fusion of $\mathrm{A} 1$ and $\mathrm{CuA}$ at apices; from Cainomerga subgen.n. in the smaller and less slender body; from Cupidium in the slender body, the longer prosternum before the coxae and the conjointly subacute elytral apices; from Menatops gen.n. in the much slender body, the longer head with the smaller eyes and the not strongly transverse pronotum; from Paracupes s.lato and Priacma in the apparently vertically sloping sides of the elytra, which show the simple edge (not thickened and tuberculate), the narrower tarsi and the more or less open antennal insertions, and also from Gracilicupes and Priacma in the Cupes-type of aedeagus. Finally it differs from Paracupoides subgen.n. in the narrower tarsi, the antennomere 2 (pedicel) only slightly shorter than scape and the following antennomeres, the more or less open and more separated antennal insertions. Apriacma gen.n. is rather distinct from Chalepocarabus in 
the presence of nine long longitudinal rows of cells, the clearly expressed primary veins and the markedly larger cells on elytra, the steeply sloping sides and subrectilinear lateral edges of the elytra, the slender body, the transverse pronotum widening anteriad, and the narrower metaventrite. It differs from Miocupes Ponomarenko, 1973 in the more slender body, the narrower and elongate head, the primary veins of elytra fused at apices, the larger elytral cells and the narrower metaventrite. Finally, the new genus differs from Priacmopsis in the much smaller and slender body, the larger antennomere 2 (pedicel) in comparison with the previous and folloving ones, the narrower metaventrite.

Notes. All four species included into this new genus were described as members of the genus Priacma, however, they have, in contrast to Priacma serrata, the rather clear Y-shaped depression on frons, the steeply sloping sides and the simple apices (without closing fold) of the elytra and the Cupes-type of aedeagus (visible in the holotype of $A$. clavata comb.n.). All these characters were ignored in their original descriptions, and for the number of the long longitudinal rows of cells on the elytra there was noted 10 (Tan et al., 2006). However the holotypes of A. tuberculosa comb.n. (Fig. 73) and (?) A. latidentata comb.n. clearly have nine rows of cells on the elytra. The prints of the other specimens do not allow calculate a precise number of rows. Three species of the new genus above mentioned have their appearance rather similar to that in the recent members of the Cupes and related genera, but (?) A. latidentata comb.n. seems to be less slender, with the elytra apparently somewhat gently sloping at sides and comparatively widely explanate along their lateral edges, the less expressed primary veins, and apparently the very weak depression on the frons. Nevetheless, because of many other similarities in the structure of the head, the antennae, the general body outline, and the shape of elytra this species is temporaly also transferred in the genus Apriacma gen.n. The holotype of one of the species included in this new genus ( $A$. clavata comb.n.) has exposed aedeagus, which is clearly different from that in Priacma serrata, supporting the distinctness of the new genus from Priacma.

\subsection{Cretomerga gen.n.}

Type species Priacmopsis subtilis Tan et Ren, 2006.

Etymology. The name of this new genus is formed from the name of the geological period Cretaceous and generic root "merga" ("Bimerga", "Merga", "Tenomerga", "Cainomerga"). Gender feminine.

Composition. The type species only.

Diagnosis. Body elongate of medium size $(11.5 \mathrm{~mm})$. Integument with moderately coarse sculpture and punctation; large subquadrangular (transverse) to polygonal cells of elytra arranged into nine long longitudinal rows interspaced by weak secondary and well raised primary veins; A1 slightly deviating at scutellum and almost completely rectilinearly reaching elytral apex, unclearly fusing with CuA and then with $\mathrm{M}$ before apex. Head looking like equilateral triangle, with rather narrow neck (about half as wide as head at temples), with expressed Y-shaped depression, well projecting temples; dorsal surface with weakly raised tubercles (paramedian longitudinal convexities along eye edge to temples), antennal insertions moderately widely separated and apparently uncovered by tubercles. Mandibles rather strong and arcuately curved at outer edge before stout bidentate apex. Antennae subfiliform and moderately long; antennomere 1 (scape) subequal in length with flagellomeres or much longer than antennomere 2 (pedicel). Pronotum subpentagonal and rectilinearly widened anteriad, with smooth disc and apparently widely explanate sides, arcuate anterior angles and strongly convex anterior edge. Part of prosternum before procoxae shorter than procoxae. Elytra about 2.2 times as long as wide combined, with broadly arcuate lateral edges, subrounded to subacute apices and apparently steeply (subvertically) sloping sides. Abdominal ventrites with a curved groove behind articulation, ventrite 1 subequal to clearly longer than each of ventrites 2-4 and hypopygidium 
somewthat longer than ventrite 1 and rounded at apex. Legs moderately thin, frequently comparatively long; with protibia straight.

Comparison. The widely separated procoxae of Cretomerga gen.n. are characteristic of the members of the subfamily Triadocupedinae, however this new genus can be scarcely put in this group because nearly all its other characters are shared by other Cupedinae rather than Triadocupedinae. It pertains to its slender body, the elytra with nine long longitudinal rows of cells, the steeply sloping sides and the very narrow epipleura while the triadocupedines have the wide and usually rather robust body, the elytra with 11 rows of very large cells, the widely explanate sides and the very wide epipleura. It is necessary to note that Cretomerga subtilis comb.n., in addition to the peculiar procoxal cavities, has the distinctly raised primary veins characteristic of many taxa in Cupedinae and Ommatinae, while most Triadocupedinae demonstrate only the rows of cells (but not well expressed veins). This new genus shares most similarities with Furcicupes, differing from the latter only in the structure of the prothoracic segment, the shape of pronotum, and the widely separated procoxae. The character to distinguish it among the taxa with the slender body having the same number of the long longitudinal row of cells and the expressed main veins of the elytra (Adinolepis, Ascioplaga, Cupes, Cupopsis gen.n., Prolixocupes, Rhipsideigma, etc.) is the clear Y-shaped depression on frons. This last character is also present in Apriacma gen.n., Furcicupes, and Kirghizocupes, although Cretomerga gen.n., except the widely separated procoxae, differs from the first of these three genera in the shorter prosternum before the procoxae, and from the third in the pronotum widening anteriad. The new genus under consideration differs from Cupidium with unclear number of the primary veins on the elytra and the short prosternum before the procoxae at least in the slender body with the rectilinear pronotal sides and the conjointly subacute elytral apices. Besides, this new genus has many diagnostic features also shared by Apriacma gen.n. (see the Diagnosis of the latter).

Note. Cretomerga gen.n. differs from Furcicupes mostly in the structure of the prothoracic segment (see above), however other distinguishing characters (shape of pronotum and widely separated procoxae) seem to be also rather important to consider "Priacmopsis subtilis" as a separate genus.

Cretomerga subtilis (Tan et Ren, 2006), comb.n.

Figs 77-79.

Priacmopsis subtilis Tan et Ren, 2006: 2655.

Specimen examined. Holotype "Priacmopsis subtilis" ("CNU-C-LB 2006003", print and counterprint).

Locality and stratigraphy. Beipiao City, Chaomidian village, Liaoning Province, China; early Cretaceous, Barremian-Aptian, Yixian Formation.

Comments to the description. This species was described without any mention of the characters important to attribute it to any genus, although many of them are quite clear in the pictures accompaining the original desciption.

Рис. 77-83. Ископаемые виды подсем. Cupedinae: 77 — Cretomerga subtilis comb.n., голотип (“CNUC-LB 2006003-1”, отпечаток, сфотографированный на микроскопе Leica MZ 12.5 с камерой Nikon Digital Camera DXM1200C); нижний мел, формация исянь; Китай, Ляонинь, Бейпяо; тело на сухом отпечатке; 78 - то же, тело; прерывистой линией очерчены вентральные склериты головы, груди, брюшка и прослеживающиеся контуры ног, не видные сверху; пунктиром Х-образное вдавление на голове и медиальная выпуклость на переднеспинке; 79 - то же, тело отпечатка под спиртом; длина экземпляра 10,3 мм; 80 - Cupopsis svitkoi (Lubkin, 2003), comb.n., голотип [“CUPC\#1339”, сфотографированный на растровом электронном микроскопе (SEM), по Lubkin (2003)]; нижний мел, турон; США, Нью Джерси, глины Олд Кроссмана; голова, антеродорсально; 81 - то же, спереди; 82 Cupopsis svitkoi (Lubkin, 2003), comb.n., дополнительный экземпляр [CUPC, без номера, сфотографированный на растровом электронном микроскопе (SEM), по Lubkin (2003)]; нижний мел, турон; США, Нью Джерси, глины Олд Кроссмана; фрагмент обугленного надкрылья, латеродорсально; 83 то же, чешуйки на верхней поверхности надкрылий. 

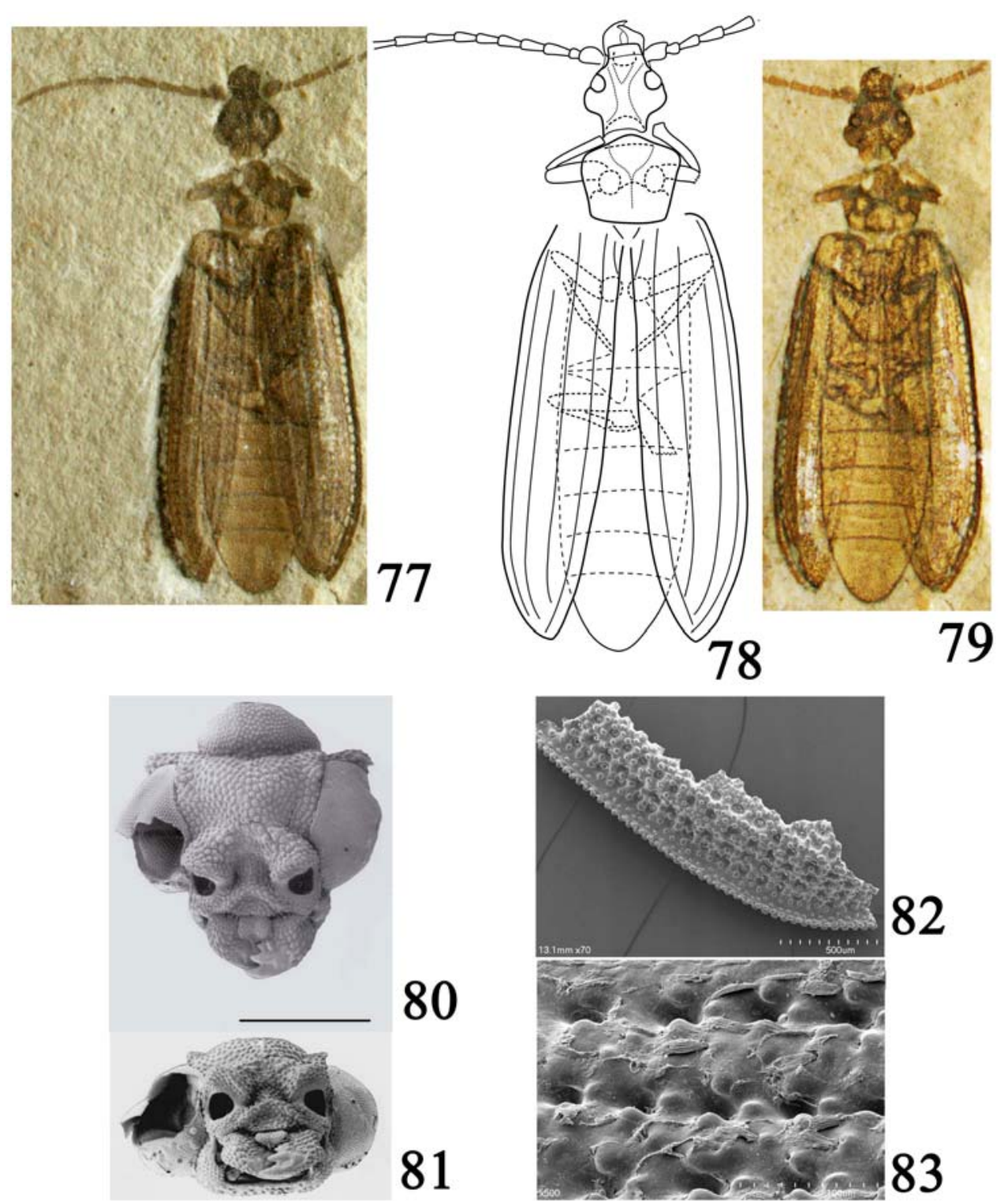

Figs 77-83. Fossil species of the subfamily Cupedinae: 77 - Cretomerga subtilis comb.n., holotype (“CNU-C-LB 2006003-1", print, photographed under Leica MZ 12.5 with camera Nikon Digital Camera DXM1200C); Lower Cretaceous, Yixian Formation; China, Liaoning, Beipiao; body on dry print; 78 idem, body with broken outlines of ventral sclerites head, thorax, abdomen and traced contours of legs invisible dorsally; and dotted line X-shaped concavity on head and mediuan convexity on pronotum; 79 idem, body on print with alcohol; length of specimen $10.3 \mathrm{~mm}$; 80 - Cupopsis svitkoi (Lubkin, 2003), comb.n., holotype ["CUPC\#1339", microgram under scanning electron microscope (SEM), after Lubkin (2003)]; Upper Cretaceous, Turonian; USA, New Jersey, Old Crossman's Clay Pit; head, anterodorsal; 81 - idem, anteral; 82 - Cupopsis svitkoi (Lubkin, 2003), comb. n., additional specimen [CUPC, without number, microgram under scanning electron microscope (SEM), after Lubkin (2003)]; Upper Cretaceous, Turonian; USA, New Jersey, Old Crossman's Clay Pit; fragment of a charcoalified elytron, laterodorsal; 83 - idem, scales on upper surface of elytra. 
Most of these characters are indicated in the above key to genera and subgenera and also in the above diagnosis. The body size was mentioned correctly in the original description (Tan, Ren, 2006: $11.5 \mathrm{~mm}$ ), but not in the later monograph (Tan, Ren, 2009: $10.27 \mathrm{~mm}$ ). The print and counterprint of the holotype demonstrate nine long longitudinal rows of cells on the elytra with only three clear rows externaly from $\mathrm{M}$ [not " 10 " as written in the original description (Tan, Ren, 2006) and in Tan \& Ren (2009)], prosternal process between widely separated procoxae without extending behind the procoxae (not "extending behind coxae" as written in the original description) and the scarcely visible gula (not "rectangular" as written in the original description). Besides, the upper surface of the head of Cretomerga subtilis comb.n. has the paramedian convexities along the eyes forming, together with the anterior triangle of the frons, the characteristic Y-shaped depression; the pronotum with a median carina in the posterior half and with a median triangular convexity in the anterior one (these structures were misinterpretated in the drawings of the descriptors, see Tan \& Ren, 2006: 2656, Fig. 1, B, C); and the elytra with reduced epipleura.

\subsection{Cupopsis gen.n.}

Type species Paracupes svetkoi Lubkin, 2003, fossil.

Etymology. The name is formed from the generic name Cupes and Greek "opsis" (view, sight, appearance). Gender feminine.

Composition. The type species only.

Diagnosis. Body apparently elongate of medium size (around $10 \mathrm{~mm}$ ). Integument with moderately coarse sculpture and punctation; large polygonal or oval cells of elytra arranged into long longitudinal rows interspaced by weak veins of subequal development. Head subtriangular, with moderately projecting temples, very large, rather wide and elongate eyes with transverse diameter as a half of distance between eyes; dorsal surface in the middle slightly convex, with well raised tubercles over antennal insertions and a deep depression between them, and also concave along distal part of eyes. Gently sloping elytral sides bearing three longitudinal rows of cells in distal half of elytra.

Comparison. This new genus is well characterized by the raised tubercles over the narrowly separated antennal insertions and the concave frons along the anterior part of the large elongate eyes. The first feature and also the elongate scales on the elytra make it possible to suppose some close relation between it and genera with steeply sloping elytral sides represented in the Recent fauna and apparently related to the genus Cupes (Adinolepis, Ascioplaga, Paracupes s.str., Paracupoides subgen.n., Prolixocupes, and Rhipsideigma), however its very large and elongate eyes together with the concavity along the anterior part of the eyes clearly separate this new genus from all others. The mentioned structure of the head allows to distinguish Cupopsis gen.n. from the other genera of the subfamily. The distal part of elytra with three rows of cells along the sloping stripe makes it possible to suppose that the complete elytron should have only nine (but not 10) long longitudinal rows of cells at least in the distal half. The probable comparatively gentle sloping elytral sides and apparently not strongly expressed difference between at least the lateral primary and the secondary veins provide an opportunity to separate this new genus from most probable relatives with such number of the long longitudinal rows (genera Adinolepis, Apriacma gen.n., Ascioplaga, Cretomerga gen.n., Cupes, Furcicupes, Prolixocupes, Rhipsideigma, Taxopsis gen.n., and probably Miocupes).

Note. This new genus represents some evidence that a probable "ancestor" of most members of the Cenozoic representatives of the subfamily with tubercles over the antennal insertions could appear not later than the late Cretaceous (Turonian). Two features of the recent "Cupes-complex" are rather crucial: subvertical sloping sides of the elytra and close (narrowly separated) antennal insertions. However the second could be a more reliable trace of "ancestry" in comparison of the first, which could be rather a sequence of homoplasy (see below the Notes to Paracupoides subgen.n.). 
Besides, it has also the medially convex frons reaching a very short triangular depression before its anterior edge. This character seems to be an autapomorphy of this genus.

The type species of this new genus cannot be put in the genus Paracupes s.lato not only because of the characteristic structure of head, but also because of the presence of only nine long longitudinal rows of cells in the distal half of the elytra while both Paracupes (Paracupes) brasiliensis and Paracupes (Paracupoides) ascius bears 10 such rows of cells along the whole length of its elytra.

Cupopsis svetkoi (Lubkin, 2003), comb.n. Figs 80-83.

Paracupes svetkoi Lubkin, 2003: 190.

Material (after Lubkin, 2003). Holotype, a three-dimensional fusainized (charcoalified) beetle head, CUPC\#1339; isolated cupedid elytra are also present in the same sediments, which can be preliminarily considered as remains of the same species.

Locality and stratigraphy. Old Crossman's Clay Pit, South Amboy Fire Clay, Middlesex County, New Jersey, USA; late Cretaceous Turonian; Raritan Formation.

\subsection{Genus Paracupes Kolbe, 1898}

\section{Paracupoides subgen.n.}

Type species Paracupes ascius Neboiss, 1989, recent.

Etymology. The name is formed from the generic name "Paracupes" and Greek "ides" or "eidos" (appearance, image, shape). Gender masculine.

Composition. The type species only.

Diagnosis. Body elongate of medium size (10.4 mm). Integument with moderately coarse sculpture and punctation; large polygonal or suboval cells of elytra arranged into 10 long longitudinal rows interspaced by well raised primary and weak secondary veins. Dorsum with large scales: elongate (lanceolate) on head, suboval on prothorax and subtriangular (widening towards truncate apex) on elytra. Scales on elytra of different color (brownish and whitish), forming on light field a pattern of three pairs of oblique dark infuscations. Underside with scales of different shape (elongate to oval or triangular) intermixed on different sclerites (median ones with wider and lateral ones with scales). Head subtriangular, with strongly projecting temples; dorsal surface with a pair of elongate and wide slightly elevated paramedian convexity along most part of head and raised tubercles over antennal insertions. Antennae subfiliform and moderately long; antennomere 1 (scape) longest and moderately thick (thickest), antennomere 2 (pedicel) shortest and subconical (slightly thicker than flagellomeres) and other antennomeres (flagellomeres) subcylindrical. Mandibles well developed, with arcuate outer edge three-dentate apices. Maxillary palpi subcylindrical, moderately long and slightly curved. Mentum of usual shape and more than twice as wide as long. Gular sutures moderately separated and subparallel-sided, anteromedian gular plate almost twice longer than wide (1.9 times). Pronotum nearly twice as wide as long, with subtruncate base, bisinuate anterior edge, subparallel and widely explanate sides, rather acuminate anterior angles, a pair of suboval slightly elevated paramedian convexities in anterior half continuing distad as not wide and slightly elevated median convex stripe. Part of prosternum before procoxae much longer than procoxae. Elytra more than 2.5 times as long as wide combined, with subparallel lateral edges, subvertically sloping sides along M; A1 curved in anterior fifth (subparallely to short anal vein) and in posterior fifth (at conjoining with $\mathrm{CuA}$ and before at conjoining of $\mathrm{A}$ and $\mathrm{CuA}$ ); apices obliquely truncate and forming a clear sutural angle; lateral edge simple and without sharp teeth. Abdominal ventrite 1 clearly longer than each of ventrites 2-4. Posterior fold of procoxae directed anteriad and subtriangular. Legs moderately thin, protibia curved at apex, tarsomeres 1-4 widely lobed.

Comparison. This subgenus can be distinguished after the above key to the genera. In addition to this key Paracupoides subgen.n. differs from the nominative Paracupes s.str. in 

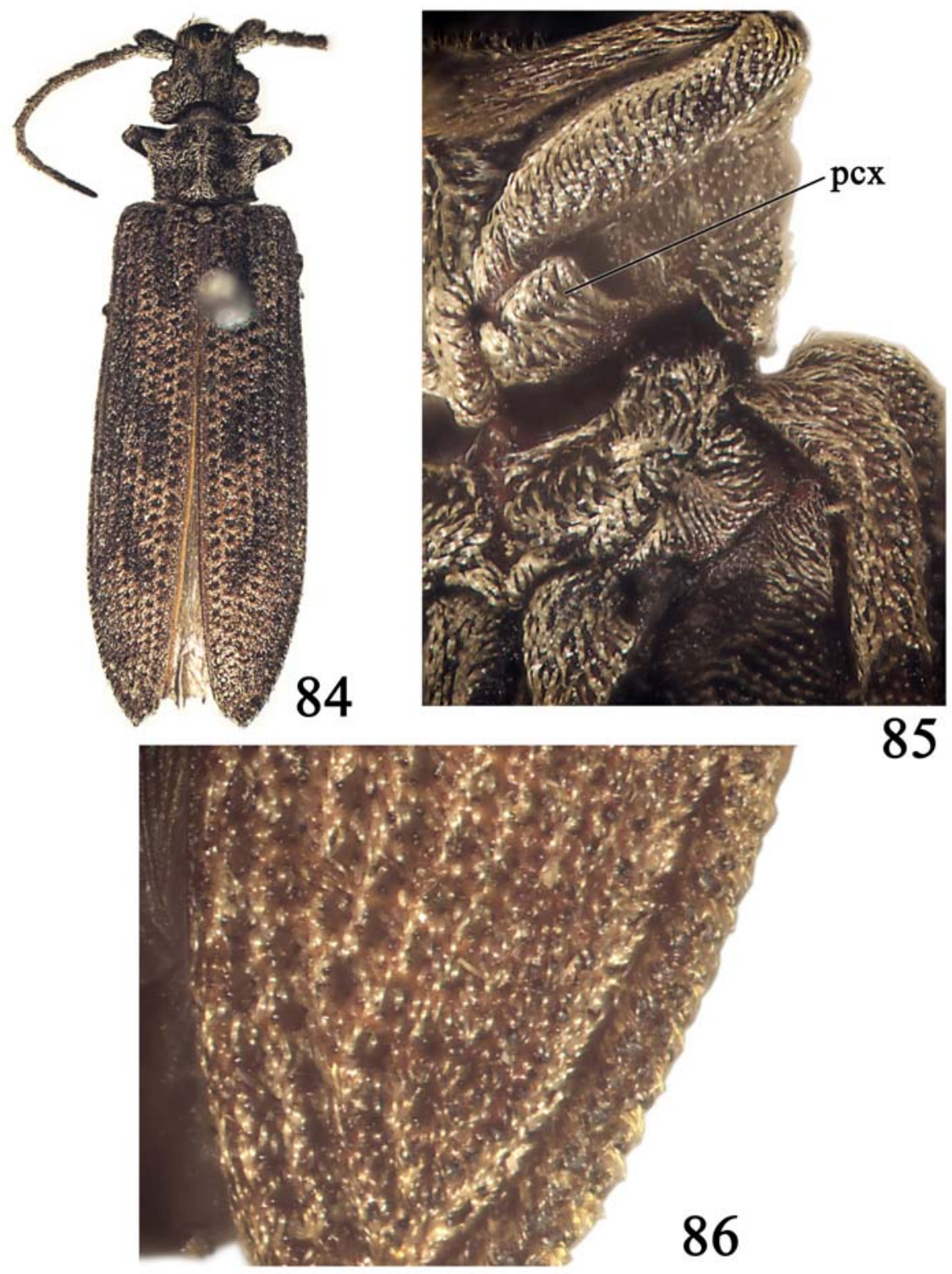

85

Figs 84-86. Paracupes (Paracupes) brasiliensis Kolbe, 1908 (MNHN, "Brasil, (?) Mur" "ex Museo Mniczech" "coll. R. Oberthur", photographed under Olympus SCX9) with camera Olympus; recent: 84 body, dorsal; 85 - pro- and mesothoraces, lateroventral; 86 - elytral apex of high magnification with clear scales, dorsal. Length of specimen $16 \mathrm{~mm}$. Abbreviation: Pcx. 1. - procoxal lobe.

Pис. 84-86. Paracupes (Paracupes) brasiliensis Kolbe, 1908 (MNHN, "Brasil, (?) Mur" "ex Museo Mniczech" "coll. R. Oberthur", сфотографированный на микроскопе Olympus SCX9) с камерой Olympus; современный: 84 - тело, сверху; 85 - передне- и среднегрудь, лптеровентрально; 86 вершина надкрылья при большом увеличении с отчетливыми чешуйками, сверху. Длина экземпляра 16 мм. Сокращение: Рcx. 1. - прококсальная лопасть. 

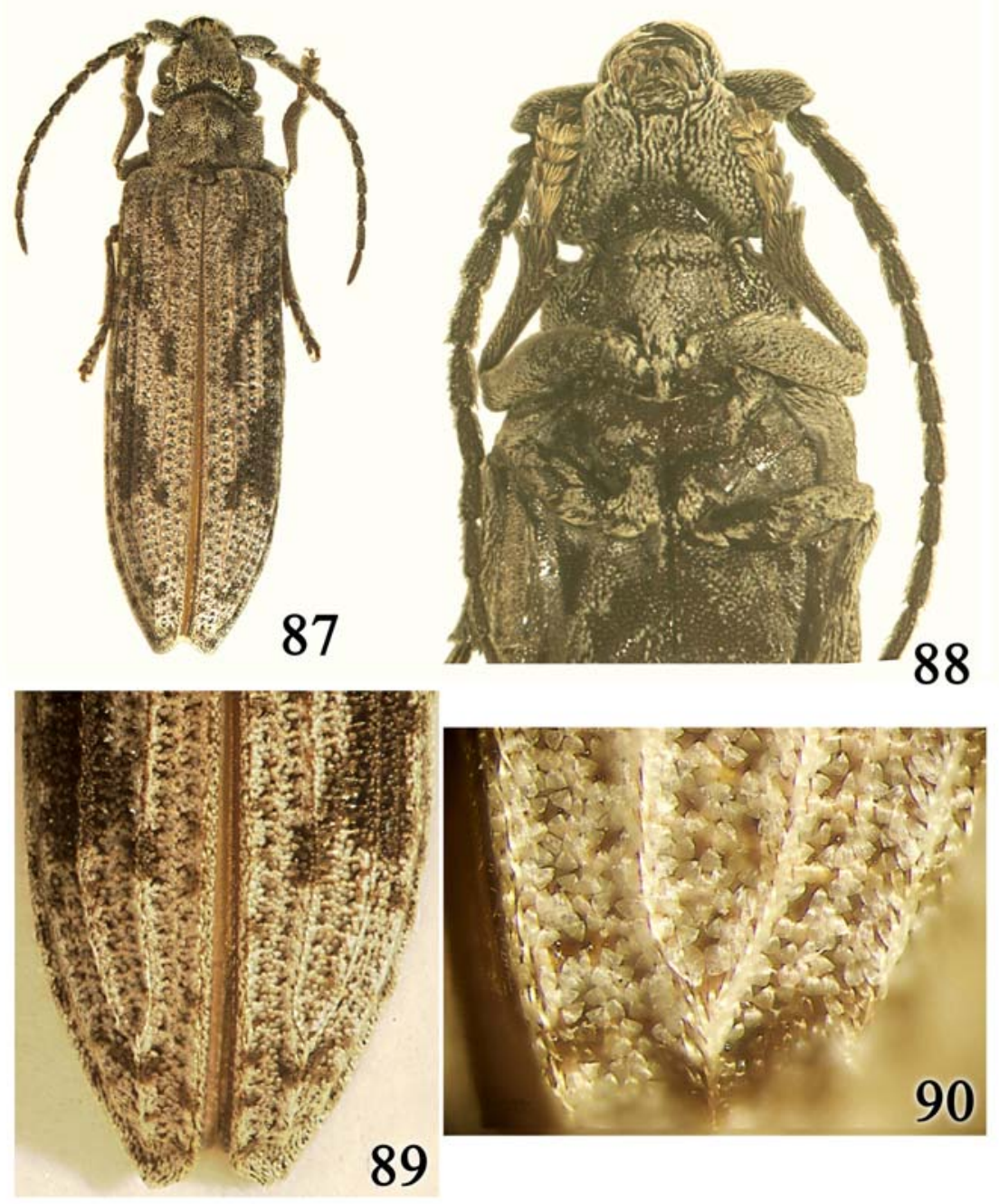

Figs 87-90. Paracupes (Paracupoides) ascius Neboiss, 1989, holotype (MNHN, "Equateur Or., de Bacos a Canelos, M. de Mathan, IX-X.1894", photographed under Olympus SCX9 with camera Olympus); recent: 87 - body, dorsal; 88 - head and thorax, ventral; 89 - elytral apices, dorsal; 90 - elytral apex of high magnification with clear scales, dorsal. Length of specimen $10.4 \mathrm{~mm}$.

Рис. 87-90. Paracupes (Paracupoides) ascius Neboiss, 1989, голотип (MNHN, "Equateur Or., de Bacos a Canelos, M. de Mathan, IX-X.1894", сфотографированный на микроскопе Olympus SCX9 с камерой Olympus); современный: 87 - тело, сверху; 88 - голова и грудь, снизу; 89 - вершины надкрылий, сверху; 90 - вершина надкрылья при большом увеличении с отчетливыми чешуйками, сверху. Длина экземпляра 10,4 мм.

the less developed mandibles [in Paracupes (Paracupes) brasiliensis they are longer and with a subangular outer edge], the surface of pronotum $[$ in $P$. ( $P$.) brasiliensis it has a median narrow and slightly elevated stripe], difference in the shape of scales on the head, pronotum and elytra [dorsum of $P$. (P.) brasiliensis is uniformly covered with narrow lanceolate scales (partly with truncate apices - see Figs $84-86$ and Vulcano \& Pereira, 1975) intermixed by thick hairs], the elytral venation (besides the weak primary veins, A1 of $P$. (P.) brasiliensis is 
almost subparallel to the suture and only slightly deviating in the anterior fifth, the short anal vein at the smaller distance from the suture), the smaller cells in four long longitudinal rows along the elytral sides and the larger cells in six rows on the disk; the posterior fold of procoxae [it in $P$. $(P)$ brasiliensis has subtrapezoid shape, but not subtriangular]. The pattern of infuscation on the dorsum of $P$. (P.) brasiliensis is quite variable and such pattern in $P$. (Paracupoides) ascius fits in the range of pattern variation of the first. The legs of these species are rather similar, including the level of curvation of protibiae.

Besides, Paracupoides subgen.n. differs from the other genera of the subfamily in the truncate elytral apices, A1 not parallel to the suture in the proximal and distal fifths and triangular scales on elytra.

It also differs from:

- Adinolepis and Ascioplaga in the not parallel long anal veins (A1), 10 complete long longitudinal rows of cells on the elytra and the lack of tarsal grooves on the ventral surface of the prothorax;

- Apriacma gen.n. in the smaller mandibles, 10 complete long longitudinal rows of suboval cells on the elytra, A1 not rectilinear before the elytral apex, the antennal insertions covered by tubercles, the protibia curved at apex and the wide tarsi;

- Chalepocarabus in the well raised primary veins, the subparallel-sides elytral edges, the larger cells on elytra, the transverse pronotum, the antennal insertions covered by the tubercles, the longer antennae with much larger scape and the larger eyes;

- Cretomerga gen.n., Furcicupes and Gracilicupes in the tubercles over the antennal insertions (antennal insertions of Cretomerga gen.n., Furcicupes, and Gracilicupes species are open), the longer prosternum before procoxae, not rectilinear A1 before the elytral apex, the curved apex of the protibiae and the wide tarsi; and also from two first groups in the wide neck and the lack of Y- or V-shaped median depression on the frons and 10 long longitudinal rows of cells on the elytra; from the third in the smaller eyes and the wider pronotum with the rectilinear sides and the projecting anterior an- gles (pronotum of Gracilicupes species is narrower than head and arcuate at sides); and also from Gracilicupes in the Cupes-type aedeagus;

- Cupes in the pair of longitudinal convexities along the vertex and frons, 10 complete long longitudinal rows of cells on the elytra, not parallel long anal veins (A1) and the lack of antennal grooves and the rather curved apex of protibiae (protibiae of Cupes species are straight or slightly curved at apex);

- Cupopsis gen.n. in the pair of longitudinal convexities on the head, the subhemispherical eyes and the not concave frons along the anterior part of the eyes and 10 complete long longitudinal rows of cells on the elytra;

- Cupidium in the somewhat more slender body with the rectilinear pronotal sides and the conjointly subacute elytral apices;

- Kirghizocupes in the much shorter head with the larger eyes, the narrower pronotum with the median carina, not rectilinear A1 before elytral apex;

- Latocupes in the slender body with the subparallel elytral lateral edges, not rectilinear A1 before elytral apex, polygonal cells on the elytra (not transverse as usually in Latocupes species), the antennal insertions covered by the tubercles and the lack of Y- or V-shaped median depression on the frons, the protibia curved at apex;

- Mesocupes in the antennal insertions covered by the tubercles, the subparallel and steeply sloping sides of elytra, not rectilinear A1 before elytral apex, the shorter and more stout legs with the curved protibiae;

- Miocupes in the much smaller head with the larger eyes, the markedly longer elytra with a great difference in development of the primary and secondary veins, and also the fusion of A1 with $\mathrm{CuA}$ before apex;

- Priacma in the elytra with the well expressed primary veins and the steeply sloping sides, the absence of the preapical closing fold on below sides of the elytra, the narrowly separated gular sutures, the longer abdominal ventrite 1, the curved protibiae and the Cupes-type aedeagus;

- Priacmopsis in the much smaller and slender body, the head with the larger eyes, the 
larger and more projecting temples, and the protibiae curved at apex;

- Prolixocupes in 10 complete long longitudinal rows of cells on the elytra, A1 curved along the short row of cells at scutellum, the head convexities not divided into tubercles over the antennal insertions and the posterior ones, the separated gular sutures, the unexpressed tarsal grooves on prothorax and the protibia curved at apex;

-Rhipsideigma in 10 complete long longitudinal rows of cells on the elytra, the very weak tubercles (convexities) on the head, the anal long vein deviating in the anterior and posterior fifths, the fusion of $\mathrm{A} 1$ and $\mathrm{CuA}$, the lack of sharp process at the place of fusion of veins;

- Taxopsis gen.n. in the smaller and more slender body, the narrower prosternal process, the not strongly transverse cells on the elytra, 10 complete long longitudinal rows of cells on the elytra, not rectilinear A1 before elytral apex and the protibiae curved at apex.

Note. Paracupes (Paracupoides) ascius seems to be closely related to P. (Paracupes) brasiliensis. The taxonomic separation is proposed to reach a balanced partition of recent representatives of the subfamily, because the characters separating the mentioned species are as important as those between the other genera of the subfamily. Moreover, differences between some genera used for recent forms are even much less expressed in comparison with those between Paracupes s.str. and Paracupoides subgen.n., reducible to the unique presence versus absence of scales on the dorsum, the shape of pregenital sclerites of the male, and the geographic distribution (Neboiss, 1984; Kirejtshuk, 2005). On the other hand, this case of two close relatives in the Recent fauna manifesting very expressive "generic" differences can be compared with the presence of different similar forms in the past, beginning from the Middle Triassic. One relative [Paracupes (Paracupes) brasiliensis] has great similarities with recent Priacma and with other taxa that are already extinct (for instance, members of Mesocupes s.str. and Cainomerga subgen.n. with 10 long longitudinal rows of cells on the elytra com- pared to those in members of Latocupes with nine rows of cells), particularly in the gently sloping sides and the not regular venation on the elytra. Also the thickened and serrate elytral sides of $P$. ( $P$. $)$ brasiliensis are rather similar to those in Priacma than in any other cupedines. Another relative [Paracupes (Paracupoides) ascius] sharing morphological features with this $P$. (P.) brasiliensis (head and appendages, except the gula and the level of development of mandibles, the truncate elytral apices, the shape of most thoracic sclerites, legs, etc.), although at the same time its important (subgeneric) peculiarities are shared by the members of the genera near Cupes with the more steeply sloping elytral sides (general appearance, and particularily the elytral structure, viz. the strongly raised primary veins, and subverticaly sloping sides). Finally, Paracupes (Paracupoides) ascius is characterised by the unique structure of scales on its integument. At the same time the male genitalia of $P$. (P.) brasiliensis can be regarded as Cupestype with the rather short appendages at base of parameres (Vulcano, Pereira, 1975) which could be regarded as plesiotypic features among closer relatives of Cupes and somewhat reminiscent homologous structures in the male genitalia of Priacma, these processes demonstrate a great variability among other species of the Recent fauna (Neboiss, 1984).

Paracupes (Paracupoides) ascius (Neboiss, 1989)

Figs 87-90.

Holotype. "Paracupes ascius sp. n., det. Neboiss 1988, HOLOTYPE”, , , "Equateur Or., de Baños à Canelos, M. de Mathan, IX-X.1894" (MNHN).

Addition to the description. Elytra thoroughly covered with subtriangular scales (widened apically) but also bearing short and fine hairs along the sutural and lateral edges; dorsal integument of prothorax and head covered with similar scales which are somewhat intermixed by more or less elongate (lanceolate) and usually apically truncate scales, along anterior edges of pronotum and head, as well as on labrum and mandibles with long and thick hairs; underside 
covered partly with subtriangular scales, partly with elongate ones, but epipleura covered completely with very long and dilated hairs (scales); appendages mostly with thick and contrast hairs, although femora and proximal part of tibiae with clear elongate scales. Cells disposed in six long longitudinal rows on elytral disk markedly larger than those in four rows along sloping sides. Primary veins (A1, CuA and M) well raised. Anteromedian gular plate almost twice as long as wide (1.9 times). Antennal grooves of prothorax rather shallow and scarcely outlined. Procoxal plates trapezium-like and covering only proximal part of protrochanter. Abdominal ventrites with tegular articulation and showing clear roller at apex and following transverse depression at base of ventrites.

\subsection{Taxopsis gen.n.}

Type species Cupes motschulskyi Kirejtshuk, 2005, fossil.

Etymology. The name of this new genus is formed from the Greek "taxis" (row, order) and "opsis" (view, sight, appearance). Gender feminine.

Locality and stratigraphy. Baltic amber; probably Kaliningrad Region, Russia; late Eocene, Bartonian/Priabonian, Prussian Formation.

Diagnosis. Body elongate of medium size (16.1-18.1 mm). Integument with moderately coarse sculpture and punctation; large subquadrangular transverse cells of elytra, which are twice as wide as long, arranged into nine long longitudinal rows interspaced by weak secondary and well raised primary veins; A1 slightly deviating at scutellum and almost completely rectilinearly reaching elytral apex, clearly fusing with $\mathrm{CuA}$ and then with $\mathrm{M}$ before apex. Head transverse and triangular, with moderately wide neck (about $3 / 4$ as wide as head at temples), without expressed Y-shaped depression, well projecting temples; dorsal surface with two pairs of weakly raised paramedian tubercles (at antennal insertions and at level of posterior edge of eyes), antennal insertions moderately narrowly separated and covered by tubercles. Mandibles moderately strong and arcuately curved. Antennae subfiliform, moderately long and thin; antennomere 1 (scape) subequal in length with flagellomeres and very swollen, antennomere 2 (pedicel) shortest and nearly $1 / 3$ as long as antennomere 3 . Pronotum subtrapezoidal, anterior and posterior edges curved, lateral sides subangular, widening from base to middle and subparallel-sided in anterior half, with smoothed disc divided by median carina and apparently widely explanate sides, anterior and posterior angles with distinct top. Part of prosternum before procoxae about 2.5 times as long as procoxae, apex of its intercoxal process widely rounded and about as wide as procoxae. Elytra about twice as long as wide combined, with broadly arcuate lateral edges, subrounded to subacute apices and sides steeply (subvertically) sloping along M. Hypopygidium about twice as long as each of ventrites 2-4, somewhat longer than wide and narrowly rounded to angular at apex. Legs moderately thin, frequently comparatively long; with protibia nearly straight.

Comparison. The genus Taxopsis gen.n. can be easily diagnosed after the above key to genera and subgenera. It shows so great similarity with Cupes that the comparison of the latter somehow fit also to this new genus. Nevertheless, this genus has the very prominent characters making it possible to regard it as a separate genus with a distinctness equal to that of other genera. The rather wide prosternal process of $T$. motschulskyi comb.n. with the widely rounded apex is the unique character among cupedines, although widely separate coxae are also known in Cretomerga gen.n. (Cupedinae) and all taxa of the subfamily Triadocupedinae. The width of procoxae in Taxopsis gen.n. is also nearly the greatest among the cupedines. The strongly transverse subquadrangular cells of elytra represent another important feature of T. motschulskyi comb.n., which is intrinsic only for species of the genus Latocupes among cupedines, however the latters have the clear Y-shaped depression on the subtriangular head (which is not so tranverse as in Taxopsis gen.n.). The elytra of some species of Cainomerga subgen.n. and 
Cupes also show a tendency to transform shape of cells in a transverse type, however these species have cells only slightly wider than long (not twice as wide as long). Also the elytron of Cainocups aixensis gen. et sp.n. (a taxon with unclear position, see above) has transverse oval cells, however the pattern of its veins is completely different.

\section{Subfamily incertae sedis}

\subsection{Cainocups gen.n.}

Type species Cainocups aixensis sp.n., fossil.

Etymology. The name of this new genus is formed from the geological term Cainozoic or

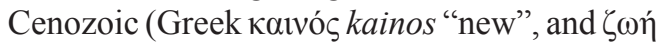
zoe "life") and abbreviation of the generic name "Cupes". Gender masculine.

Diagnosis. Distal part of elytron with 12 long longitudinal rows of transversely oval cells interspaced by the weak secondary and the well raised primary veins; $\mathrm{R}$ and $\mathrm{M}$ fusing first and joint vein fusing at first with $\mathrm{CuA}$ and then with A1 (Fig. 76). Elytral side apparently steeply (subvertically) sloping without lateral explanation.

Comparison. The sequence of the fusion of the primary veins in Cainocups aixensis gen. et sp.n. is very unusual and does not occur not only among members of the subfamily Cupedinae, but also among other two subfamilies of Cupedidae. The generalized type of fusion of primary veins of the family includes the fusion of A1 with the arcuately curved $\mathrm{CuA}$ at elytral apices and in many cases to this join vein (after fusion of $\mathrm{A} 1$ and $\mathrm{CuA}$ ) arcuately curved $\mathrm{M}$ can be attached or fused (most genera of all subfamilies). However among many species of Notocupes (Ommatinae) this type of fusion is also observed and a tendency for independent fusion of $\mathrm{A} 1$ with $\mathrm{CuA}$ and also the fusion of $\mathrm{M}$ and $\mathrm{R}$ can be traced. Ponomarenko (2006) reconstructed the ground-plan of the elytron for Zygadenia Handlirsch, 1906 in which he drew a sequence of the fusion of the primary veins at elytral apex including the first fusion of $\mathrm{M}$ and $\mathrm{CuA}$ and the second fusion of this join vein and A1 (Ponomarenko, 2006: 96, Fig. 4).
The number of the long longitudinal rows of cells on the elytra of Cainocups gen.n. (12) is unique among the cupedines. The number of these rows of cells in the family varies between nine and 11 , although the usual ones are nine or 10 (see above the Notes on the structural peculiarities of the family).

The pattern of the elytral venation of Cainocups gen.n. makes it possible to certainly define the attribution of this genus to the family Cupedidae, as the fusion of the primary veins at elytral apices is characteristic of this family. However because of uniqueness of the vein pattern on elytra this new genus cannot be put in any subfamily with confidence. Nevertheless some analogical features in the elytral venation of Cainocups gen.n. can be noticed in that of Menatops gen.n. (see above), particularly in well raised $\mathrm{R}$ and $\mathrm{M}$, fusion of $\mathrm{M}$ with $\mathrm{A} 1 \mathrm{after}$ the fusion of $\mathrm{M}$ with $\mathrm{CuA}$ (Figs 10-11). This similarity could be used for putting the new genus under consideration into the subfamily Cupedinae. The apparently steeply sloping of the elytral side along $\mathrm{R}$ in this new genus is also the unique feature (usually such sloping occurs along $\mathrm{M}$ ) and gives no argumentation for a more precise attribution of this new genus. The next feature which could be considered in this context is the type of sloping of elytral side. The steep (subvertical) sloping is observed in both Cupedinae and Ommatinae, however among the latter there are many forms combining the subvertical sloping and the lateral explanation of elytral sides. The very diverse genus Notocupes includes representatives with somewhat similar patterns of the elytral venation, although they also show the clear lateral explanation along the lateral edge of the elytra [for example, $N$. eumera (Tan, Ren et Shih, 2006), N. porrectus (Tan, Ren et Shih, 2006), and N. stabilis (Tan, Ren et Liu, 2005) with independent fusion of $\mathrm{A} 1$ and $\mathrm{CuA}$ as well as fusion of $\mathrm{M}$ and $\mathrm{R}$; etc.]. Thereby the position of the genus Cainocups gen.n. should be interpreted as uncertain among the Cupedidae.

Taking into consideration the length of the fragment of the elytron of the holotype of Cainocups aixensis gen. et sp.n., the probable length of the whole beetle, to which it belonged, can be estimated as approximately $15 \mathrm{~mm}$. 
Cainocups aixensis sp.n. Fig. 76.

Holotype. Specimen MNHN-F-A 51230 ("Aix 18, Nel leg"). The specimen is represented by a fragment of the elytron in the piece of comparatively hard rock.

Locality and stratigraphy. Palaeogene, Latest Oligocene; France, Jas de Bouffan, town Aix-en-Provence, Bouches-du-Rhône.

Note. This fossil fragment of the elytron is the unique specimen of this species among 10 thousands of beetles collected in the same layers. Cainocups aixensis sp.n. seems to have been an extremely rare taxon in deposits of the latest Oligocene (only known in its type deposit and known by only one specimen among 50000 fossil insects).

Description. Length of print of elytron 6.3 $\mathrm{mm}$. R almost gradually arcuate, meeting with sutural edge just at elytral apex and dividing elytron into a flat disk and a steeply sloping side (Fig. 76). Eight long longitudinal rows on elytral disk consisting of transversely elliptic cells more than twice as wide as long, interspace between them in rows about as great as length of cells; cells on sloping part of elytron not so strongly transverse to oval, somewhat smaller and apparently shallower.

\section{Lists of fossil taxa re-examined}

The generic and subgeneric taxa mentioned in the below lists include only those that are possible to interpret after study of the specimens and original descriptions with informative illustrations. In cases when the authors of this paper used only the descriptions without checking specimens the corresponding publications cited by indication of the authors' name(s) and year after the Latin names of taxa are given in the References. Some taxa are omitted in this appendix because of difficulties of interpretation on the available data, particularly those proposed after isolated elytra or described with considerable deficiences. Some information on the taxa that remained without consideration can be obtained in the catalogue by Kirejtshuk \& Ponomarenko (2016).

\subsection{List of fossil genera and subgenera of Cupedinae}

Apriacma gen.n.

(see above Diagnosis of this genus)

- Apriacmaclavata (Tan, Ren et Shih, 2006), comb.n. [Priacma]; early Cretaceous, Barremian-Aptian, Yixian Formation; China, Liaoning, Beipiao.

- (?) Apriacma latidentata (Tan, Ren et Shih, 2006), comb.n. [Priacma]; early Cretaceous, Barremian-Aptian, Yixian Formation; China, Liaoning, Beipiao.

- Apriacmarenaria (Tan, Ren et Shih, 2006), comb.n. [Priacma]; early Cretaceous, Barremian-Aptian, Yixian Formation; China, Liaoning, Beipiao.

- Apriacma tuberculosa (Tan, Ren et Shih, 2006), comb.n. [Priacma]; early Cretaceous, Barremian-Aptian, Yixian Formation; China, Liaoning, Beipiao.

Genus Chalepocarabus Handlirsch, 1906 (after Ponomarenko, 2006)

This genus was proposed in the short notes of the monograph of Handlirsch, 1906 (19061908), and later Crowson (1962) and Ponomarenko $(1969,2006)$ re-defined its position. The interpretation of the last publication (Ponomarenko, 2006) is recognized in this paper. The main features of this genus are the very long pronotum and comparatively small cells disposed in 10 long longitudinal rows between unexpressed veins on elytra. Besides, this genus has the gently sloping elytral sides, the somewhat tuberculate upper surface of the head, and the rather separated antennal insertions. Somehow this group seems to be close to Mesocupes (particularly could be close to Anaglyphites stat.n.) differing from the latter mostly in the shape of its long pronotum, the very obliterated elytral integument and the rather small cells on the elytra.

- Chalepocarabus elongatus (Brodie, 1845) [Carabus]; early Cretaceous (unless Late Jurassic), England, Wiltshire, Early Purbeck, Vale of Wardour.

\section{Cretomerga gen.n.}

(see the above Diagnosis of this genus)

- Cretomerga subtilis (Tan et Ren, 2006), comb.n. [Priacmopsis]; early Cretaceous, Bar- 
remian-Aptian, Yixian Formation; China, Liaoning, Beipiao.

Genus Cupes Fabricius, 1801

(= Cupoides Motschoulsky, 1856; Tenomerga Nebois, 1984; Distocupes Neboiss, 1984)

(see the above Diagnosis of this genus)

- Cupes distinctissimus sp.n.; Paleogene, Paleocene; France, Puy-de-Dome, Menat.

- Cupes eckfeldensis (Tröster, 1993), comb.n. [Tenomerga]; Paleogene, Middle Eocene; Germany, Rheinland-Pfalz, Rhine Palatine, Eckfelder Maar.

- Cupes groehni Kirejtshuk, 2005; Paleogene, late Eocene; Baltic See coast, Russia, near Kaliningrad (formerly Königsberg), Jantarny, Baltic amber.

- Cupes hoffeinsorum Kirejtshuk, 2005; Paleogene, late Eocene; Baltic See coast, Russia, near Kaliningrad (formerly Königsberg), Jantarny, Baltic amber.

- Cupes kerneggeri Kirejtshuk, 2005; Paleogene, late Eocene; Baltic See coast, Russia, near Kaliningrad (formerly Königsberg), Jantarny, Baltic amber.

- Cupes komissari Kirejtshuk, 2005; Paleogene, late Eocene; Baltic See coast, Russia, near Kaliningrad (formerly Königsberg), Jantarny, Baltic amber.

- Cupes manifestus Kirejtshuk, Nel et Colomb, 2010; Paleogene, Paleocene; France, Puyde-Dome, Menat.

- Cupes messelensis (Tröster, 1993), comb.n. [Tenomerga]; Paleogene, Middle Eocene; Germany, 9 km NE Darmstadt, Messel.

- Cupes ponomarenkoi Kirejtshuk, Nel et Colomb, 2010; Paleogene, earliest Eocene; France Paris Basin, Le Quesnoy, Oise amber.

- Cupes praeglacialis Gersdorf, 1976; Neogene, late Pliocene; Germany, Niedersachsen, Harz, Willershausen.

- Cupes rohdendorfi Iablokoff-Khnzorian, 1960; Paleogene, late Eocene; Baltic See coast, Russia, near Kaliningrad (formerly Königsberg), Jantarny, Baltic amber.

- Cupes simillimus sp.n.; Paleogene, Paleocene; France, Puy-de-Dome, Menat.

- Cupes tesselatus (Motschoulsky, 1856) [Cupoides]; Paleogene, late Eocene; Baltic See coast, Russia, near Kaliningrad (formerly Königsberg), Jantarny, Baltic amber.

- Cupes weitschati Kirejtshuk, 2005; Paleogene, late Eocene; Baltic See coast, Russia, near Kaliningrad (formerly Königsberg), Jantarny, Baltic amber.

Genus Cupidium Ponomarenko, 1968

This group, on the one hand, is similar to Cretomerga gen.n., Gracilicupes and Furcicupes by its very short prosternum before the procoxae, but differs from all of them in the more robust body with the elytra, which are somewhat less than twice as long as wide combined, widely and separately rounded at apices and gently sloping at sides, and the comparatively small eyes; moreover Cupidium differs also from the first in the narrowly separated procoxae; from the second in the not so narrow prothorax (which is about as wide as head) and neck; and from the third in the arcuate sides of pronotum and the not so narrow neck. On the other hand, Cupidium abavum could be considered close of the genus Mesocupes, having the general appearance and the subparallel-sided elytra as those in Mesocupes s.str. Finally the single species of the genus demonstrates the separately rounded elytral apices forming a comparatively deep sutural angle which make this genus quite distinct from all mentioned taxa.

- Cupidium abavum Ponomarenko, 1968; late Jurassic, Oxfordian (or/and Kimmeridgian); Kazakhstan, Chimkent Region, Kara-Tau Range, Karatau.

\section{Cupopsis gen.n.}

(see above Diagnosis of this genus)

- Cupopsis svitkoi (Lubkin, 2003), comb.n. (Paracupes); late Cretaceous, Turonian; USA, New Jersey, Middlesex County, Old Crossman's Clay Pit.

Genus Furcicupes Tan et Ren, 2006

This genus is characterized by the very slender body, the head with the clear Y-shaped depression and the rather narrow neck, the very short prosternum before the procoxae and apparently nine rows of cells on the elytra. The 

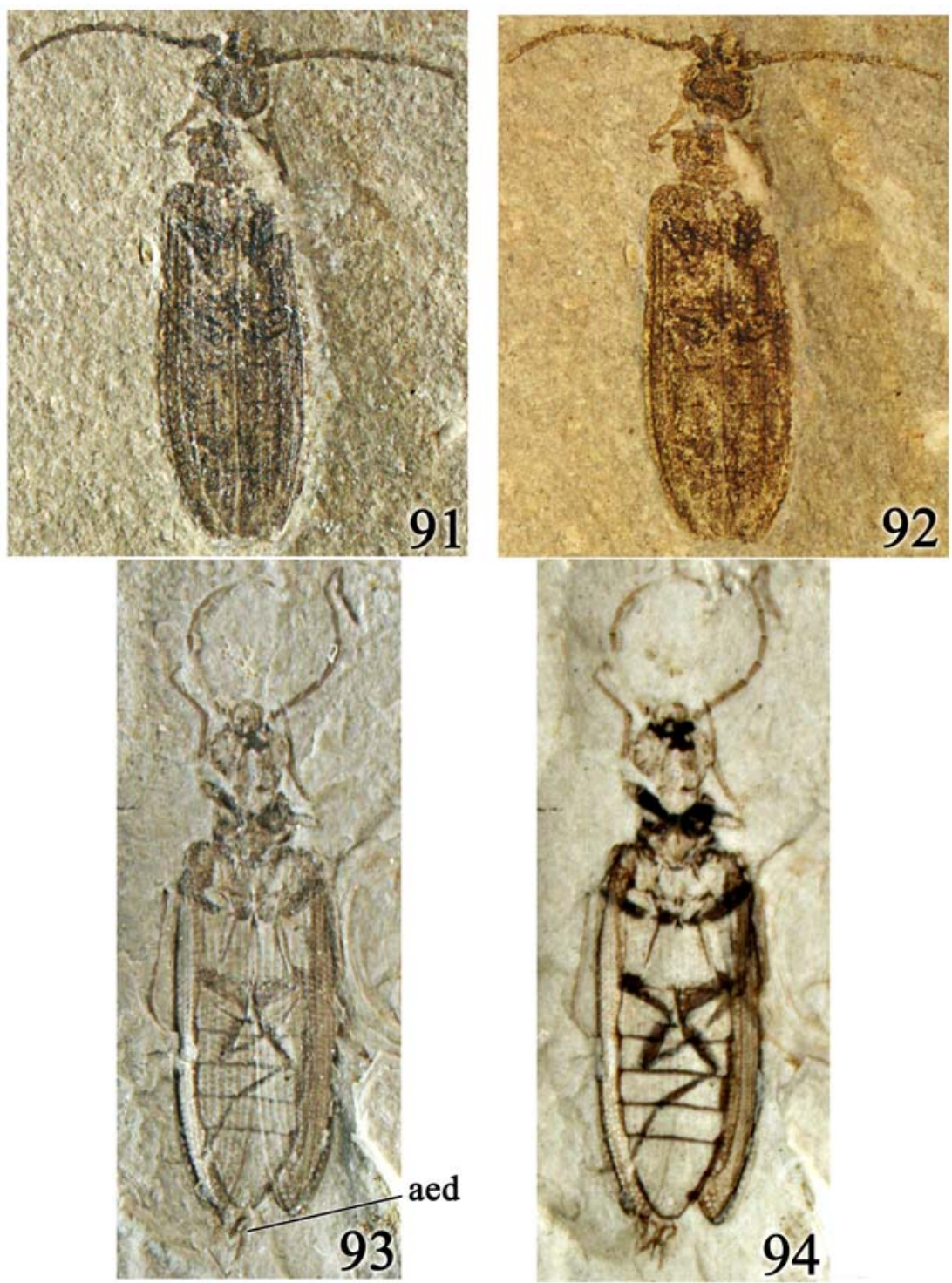

Figs 91-94. Fossil species of the subfamily Cupedinae, photographed under Leica MZ 12.5 with camera Nikon Digital Camera DXM1200C: 91 - dry print of holotype of Furcicupes raucus Tan et Ren, 2006 ("CNU-C-LB2006004"); Lower Cretaceous, Yixian Formation; China, Liaoning, Beipiao; length of body $9.2 \mathrm{~mm}$; 92 - idem, covered by alcohol; 93 - dry print of holotype of Gracilicupes tenuicruralis Tan, Ren et Shin, 2006 ("CNU-C-LB2005002"); Middle Jurassic, Jiulongshan Formation; Inner Mongolia; Chifeng City, Daohugou; dry print, length of body $11.4 \mathrm{~mm} ; 94$ - idem, covered by alcohol. Abbreviation: aed aedeagus.

Рис. 91-94. Ископаемые виды подсем. Сupedinae, сфотографированные на микроскопе Leica MZ 12.5 с камерой Nikon Digital Camera DXM1200C: 91 - сухой отпечаток голотипа Furcicupes raucus Tan et Ren, 2006 (“CNU-C-LB2006004”); нижний мел, формация Исянь; Китай, Ляонинь, Бейпяо; длина тела 9,2 мм; 92 - то же, покрытый спиртом; 93 - сухой отпечаток голотипа Gracilicupes tenuicruralis Tan, Ren et Shin, 2006 (“CNU-C-LB2005002”); средняя юра, формация Джулиньшан; Внутренняя Монголия; Чифен, Даохугоу; сухой отпечаток, длина теля 11,4 мм; 94 - то же, покрытый спиртом. Сокращение: aed - эдеагус. 
neck of this genus is the narrowest among cupedines, although it can be somewhat compared with that in Gracilicupes. The very short prostenum before the procoxae is known also for genera Cupidium, Cretomerga gen.n. and Gracilicupes, although Furcicupes differs from the first in the more slender body, the longer elytra with the steeply sloping sides, the larger eyes; from the second in the narrowly separated procoxae and the open antennal insertions; and from third in the wider prothorax. Tan \& Ren (2006) regarded that the type species of this genus has eight long longitudinal rows of cells on its elytra, however, the re-examimation of this specimen showed that there are three rows of cells located externally from M (but not two: Fig. 91).

-Furcicupes raucus Tan et Ren, 2006; early Cretaceous, ? Barremian-Aptian, Yixian Formation; China, Liaoning, Beipiao.

Genus Gracilicupes Tan, Ren et Shin, 2006

This genus was proposed for two species having a rather slender body; the large head with the comparatively narrow neck, very large eyes, long antennae; very narrow pronotum with the arcuate sides (markedly narrower than head), not projecting anterior and posterior angles; very short part of prosternum before the procoxae, the elytra with 10 long longitudinal rows of cells, the well raised primary veins different in expression from the secondary veins, and the steeply sloping sides. The most distinct character of this genus is the prothorax, which is much narrower than head. The very short prosternum is characteristic of not only this genus, but also of Cretomerga gen.n., Cupidium, and Furcicupes (see above the characteristics of these genera and the above key to genera and subgenera). This genus demonstrates some similarities to the structures of the "complex of genera" closely related to Cupes with the slender body and nine long longitudinal rows of cells on the elytra.

- Gracilicupes crassicruralis Tan, Ren et Shin, 2006; Middle Jurassic, Jiulongshan Formation; Inner Mongolia; Chifeng City, Daohugou.
- Gracilicupes tenuicruralis Tan, Ren et Shin, 2006 (=tenuocruralis: Tan et Ren, 2009); Middle Jurassic, Jiulongshan Formation; Inner Mongolia; Chifeng City, Daohugou.

Genus Kirghizocupes Ponomarenko, 1966

(=Mesocupoides Ponomarenko, 1969, syn.n.)

This genus represents the oldest group of the cupedines in the fossil record, with the rather slender and very convex body and the steeply sloping sides of the elytra. It is somehow more similar to Priacma because of 10 long longitudinal rows of cells on the elytra, which are apparently as flat as in Cupes, and, in addition to these rows of cells, one additional row is visible just between Sc and edge of elytra. This genus is characterized by the very peculiar elongate head with a pair of the long paramedian convexities and the open antennal insertions, the rather wide pronotum with the very widely (sub)explanate sides, the comparatively medium body-size (length $5.0-7.5 \mathrm{~mm}$ ), and particularly with the slightly different primary and secondary veins gradually converging at apex, but without clear fusion.

The type species of both Kirghizocupes (K. cellulosus) and Mesocupoides (M. proporeius) are certainly rather closely related and mostly distinguished by the characters of the shape of the head and pronotum, the length of antennae and also in the different distances between procoxae (a little greater in Kirghizocupes and a little smaller in Mesocupoides). Therefore they can be scarcely considered as separate genera. Kirghizocupes could be placed among the members of Cupedinae but not Triadocupedinae, although the distance between the procoxae in Kirghizocupes cellulosus is not very narrow (Ponomarenko, 1966a: 60). The elytra of the holotypes of the type species of both "genera" have steep subvertical sides with sharp inflection externally from seventh long rows of cells (Figs 109-111), although some specimens demonstrate not so sharp inflection or even smooth but with distinct long longitudinal rows of cells on the rather wide sloping lateral stripes of the elytra (Fig. 116). 
This genus unites some species from the same localities and some of them were described in the genera here synonymized and, perhaps, partly in genera Asimma and Pterocupes (see below). Some species probably related to this group and deposited in the collection of PIN still remain undescribed. Among members of this group two subgroups can be defined according to the length of the ultimate abdominal ventrite (hypopygidium) which looks in some cases shorter, but in other cases divided into two parts (two sclerites).

- Kirghizocupes cellulosus Ponomarenko, 1966; ? Middle-late Triassic, Ladinian-Karnian; Kyrgyzstan, Osh Region, Djailaucho (Dzhayloucho), Madygen.

- Kirghizocupes proporeius (Ponomarenko, 1969), comb.n. [Mesocupoides]; ? Middlelate Triassic, Ladinian-Karnian; Kyrgyzstan, Osh Region, Djailaucho (Dzhayloucho), Madygen.

- Kirghizocupes indistinctus (Ponomarenko, 1969, comb.n. [Mesocupoides]; ? Middlelate Triassic, Ladinian-Karnian; Kyrgyzstan, Osh Region, Djailaucho (Dzhayloucho), Madygen.

Genus Latocupes Tan et Ren, 2006

(? = Pulchicupes Ren, 1995)

The name Latocupes was synonymized by Kirejtshuk et al. (2010) to Priacmopsis, however it is possible to distinguish the latter and Latocupes by the V-or Y-shaped depression on frons, which is lacking in Priacmopsis and, in addition to this, Latocupes has the very characteristic transverse cells on the elytra. These characters combining with the comparatively robust body and the widely transverse pronotum could make it possible to synonymize it with Pulchicupes described as a member of the family Taldycupedidae (Ren et al., 1995). However, the drawing in the original description of Pulchicupes jiensis (Ren et al., 1995) shows 10 long longitudinal rows of transverse cells on elytra, but the photographs accompanying it do not allow verifying the exact number of rows of cells. Therefore synonymy of these generic names is regarded as preliminary and should be clarified after a further re-examination of the type specimen of Pulchicupes jiensis. Due to the considered characters the species from Daohugou described as members of Mesocupes were transferred into the Latocupes because at least in 'Mesocupes collaris' the V- or Y-depression on the head and other characters of this genus can be easily traced and according to the original descriptions this character was observed in other species described as Mesocupes from Daohugou. Besides, Latocupes is characterized by nine long longitudinal rows of cells on the elytra (clearly visible in the holotypes of Latocupes angustilabialis comb.n., L. bella and $L$. fortis) within the primary veins, which sometimes seem to be slightly expressed. Tan \& Ren (2006) indicated 10 long longitudinal rows for the species described by them in the composition of the genus Latocupes and later Tan et al. (2007) mentioned nine rows for species described by them as members of the genus " $\mathrm{Me}$ socupes". In the latter paper there are some photographs and drawings of cells at the elytral sides which are not quite strongly transverse, but the cells on the elytral discs in these specimens are about twice as wide as long.

- (?) Pulchicupes jiensis Ren, 1995; early Cretaceous, Lushangfen Formation; China, Western Beijing Province, Jingxi Basin, Lushangfen village.

- Latocupes bella Tan et Ren, 2006; early Cretaceous, Barremian-Aptian, Yixian Formation; China, Liaoning, Beipiao;

- Latocupes fortis Tan et Ren, 2006; early Cretaceous, Barremian-Aptian, Yixian Formation; China, Liaoning, Beipiao;

- Latocupes angustilabialis (Tan, Huang et Ren, 2007), comb.n. (Mesocupes); Middle Jurassic, Jiulongshan Formation; Inner Mongolia; Chifeng City, Daohugou.

- Latocupes collaris (Tan, Huang et Ren, 2007), comb.n. (Mesocupes); Middle Jurassic, Jiulongshan Formation; Inner Mongolia; Chifeng City, Daohugou.

- Latocupes latilabialis (Tan, Huang et Ren, 2007), comb.n. (Mesocupes); Middle Jurassic, Jiulongshan Formation; Inner Mongolia; Chifeng City, Daohugou. 

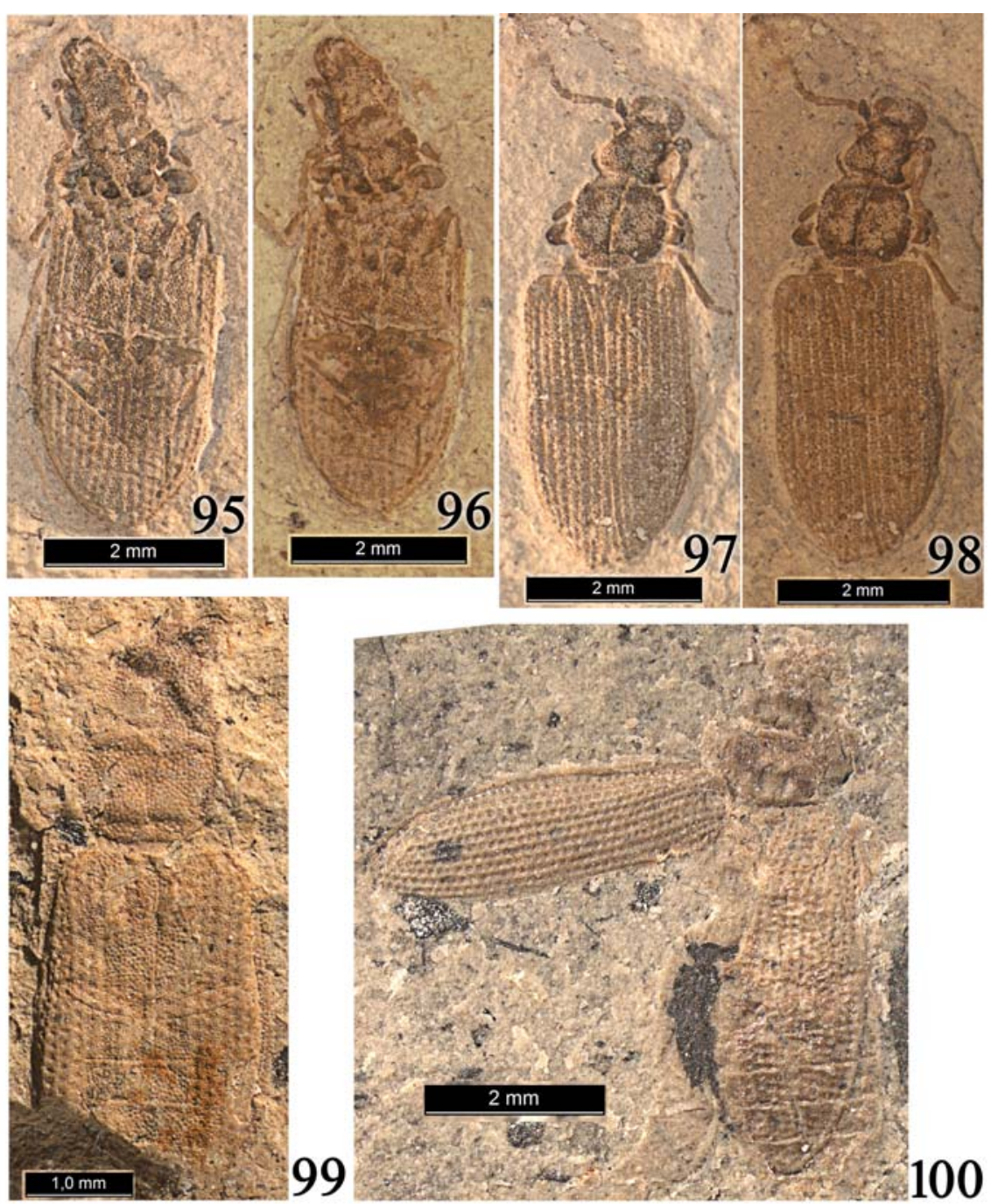

Figs 95-100. Fossil species of the subgenus Anaglyphites, photographed under Leica MZ 9.0 with camera DFC290: 95-96 — print of holotype of Mesocupes (Anaglyphites) capitatus (Ponomarenko, 1966), comb.n. ("PIN 1989/2993"): 95 — dry print, 96 — print covered by alcohol; Lower Cretaceous, Middle Neocomian; Russia, Transbaikalia, Buryatya, Baissa; length of body $5.8 \mathrm{~mm}$; 97-98 - counterprint of holotype of $M$. (A.) capitatus comb.n. ("PIN 1989/1869": 97 - dry counterprint, 98 - counterprint covered by alcohol); 99 - dry print of holotype of M. (A.) mongolicus (Ponomarenko, 1997), comb.n. ("PIN 3559/1608"); Lower Cretaceous, ? Lower Aptian; Mongolia, Bon Tsagan; length of body $6.3 \mathrm{~mm} ; 100$ — dry print of paratype of M. (A.) mongolicus comb.n. ("PIN 3790/277"), length of body $6.3 \mathrm{~mm}$.

Рис. 95-100. Ископаемые виды подрода Anaglyphites, сфотографированные на микроскопе Leica MZ 9.0 с камерой DFC290: 95-96 - отпечаток голотипа Mesocupes (Anaglyphites) capitatus (Ponomarenko, 1966), comb.n. (“PIN 1989/2993”): 95 - сухой отпечаток, 96 - отпечаток, покрытый спиртом; нижний мел, средний неоком; Россия, Забайкалье, Бурятия, Байса; длина теля 5,8 мм; 97-98 противоотпечаток голотипа M. (A.) capitatus comb.n. (“PIN 1989/1869”): 97 — сухой противоотпечаток, 98 - противоотпечаток, покрытый спиртом; 99 - сухой отпечаток голотипа M. (A.) mongolicus (Ponomarenko, 1997), comb.n. ("PIN 3559/1608”); нижний мел, ? нижний апт; Монголия, Бон Цаган; длина тела 6,3 мм; 100 - сухой отпечаток паратипа M. (A.) mongolicus comb.n. (“PIN 3790/277”), длина тела 6,3 мм. 


\section{Menatops gen.n.}

(see above Diagnosis of this genus)

- Menatops orbiculatus (Kirejtshuk, Nel et Colomb, 2010) [Cupes], comb.n.; Paleogene, Paleocene; France, Puy-de-Dome, Menat.

- Menatops bartenevi sp.n.; Paleogene, Paleocene; France, Puy-de-Dome, Menat.

Genus Mesocupes Martynov, 1926

(see above Diagnosis of this genus)

Subgenus Mesocupes Martynov, 1926, s.str.

- Mesocupes (Mesocupes) bidens Ponomarenko, 1964; late Jurassic, Oxfordian (or/and Kimmeridgian); Kazakhstan Chimkent Region, Kara-Tau Range, Karatau.

- Mesocupes (Mesocupes) primitivus Martynov, 1926; late Jurassic, Oxfordian (or/and Kimmeridgian); Kazakhstan, Chimkent Region, Kara-Tau Range, Karatau.

- Mesocupes (Mesocupes) minor Ponomarenko, 1968; late Jurassic, Oxfordian (or/and Kimmeridgian); Kazakhstan, Chimkent Region, Kara-Tau Range, Karatau.

- Mesocupes (Mesocupes) paulus (Ponomarenko, 1964), comb.n. [Anaglyphites]; late Jurassic, Oxfordian (or/and Kimmeridgian); Kazakhstan, Chimkent Region, Kara-Tau Range, Karatau.

- Mesocupes (Mesocupes) spinosus Ponomarenko, 1964; late Jurassic, Oxfordian (or/and Kimmeridgian); Kazakhstan, Chimkent Region, Kara-Tau Range, Karatau.

- Mesocupes (Mesocupes) zherikhini (Soriano et Delclós, 2006), comb.n. [Anaglyphites]; early Cretaceous, Barremian; Spain, Cuenca, 4 km NO from village Cierva, Las Hoyas.

Subgenus Anaglyphites Ponomarenko, 1964, stat.n.

The species of this subgenus have large cells in the long longitudinal subparallel rows on the elytra (sometimes rows are not clearly expressed), slightly expressed veins on the elytra without fusion at apices (somewhat like those in some Mesocupes), open and rather separated antennal insertions, subflattened dorsal surface of the head and subfiliform antennae with the antennomere 3 very long while the species of
Mesocupes s.str. have the primary veins more expressed and subfiliform antennae with comparably shorter antennomeres 2 and 3. Nevertheless Anaglyphites is very distinct due to the comparatively shorter elytra which are usually about 1.5 times as long as wide combined or not infrequently slightly shorter while the elytra in Mesocupes s.str. are generally longer. The type specimen of Mesocupes (Anaglyphites) capitatus comb.n. shows a row of cells between elytral Sc and lateral edge of the elytra while the elytra of some specimens of $M$. (A.) admotus comb.n. and $M$. (A.) clavatus comb.n. bear the sharply and densely tuberculate or teethed (densely crenellate at adge) stripes along the lateral edge (similar to those in Priacma and Paracupes s.str.). The pronotum of most specimens of this subgenus demonstrate the finely crenelate sides (Figs 95-102). Besides, the elytra of some species of this subgenus have the rather steep elytral sides with the sharp inflection [Mesocupes (Anaglyphites) capitatus comb.n.] while the paratype of M. (A.) mongolicus comb.n. has the longitudinal rows of cells on the elytra which give an impression of fusion of the traces of A1 and $\mathrm{CuA}$ (Fig. 100).

- Mesocupes (Anaglyphites) admotus (Ponomarenko, 1964), comb.n. [Anaglyphites]; late Jurassic, Oxfordian (or/and Kimmeridgian); Kazakhstan Chimkent Region, Kara-Tau Range, Karatau.

- Mesocupes (Anaglyphites) capitatus (Ponomarenko, 1966), comb.n. [Anaglyphites]; early Cretaceous, Middle Neocomian; Russia, Transbaikalia, Buryatya, Baissa.

- Mesocupes (Anaglyphites) clavatus (Ponomarenko, 1964), comb.n. [Anaglyphites]; late Jurassic, Oxfordian (or/and Kimmeridgian); Kazakhstan, Chimkent Region, Kara-Tau Range, Karatau.

- Mesocupes (Anaglyphites) minimus Ponomarenko, 1997), comb.n. [Priacmopsis]; Early Cretaceous, ? early Aptian, Bontsagan series; Mongolia, Bayan-Khongor Ajmag, Bon Tsagan.

- Mesocupes (Anaglyphites) mongolicus (Ponomarenko, 1997), comb.n. [Anaglyphites]; early Cretaceous, ? early Aptian, Bontsagan series; Mongolia, Bayan-Khongor Ajmag, Bon Tsagan. 

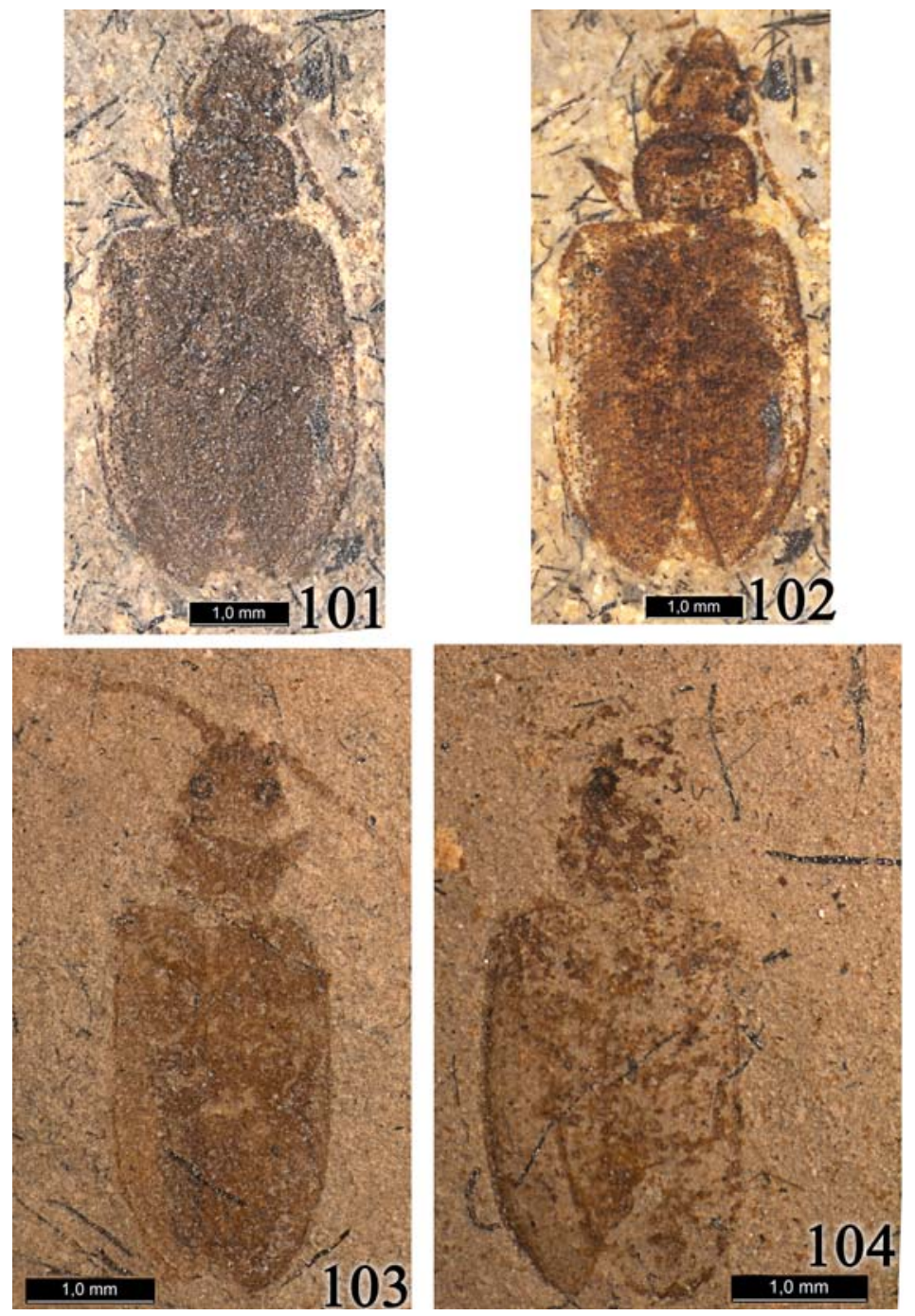

Figs 101-104. Fossil species of the subgenera Anaglyphites and Mesocupes s.str. (genus Mesocupes), photographed under Leica MZ 9.0 with camera DFC290: 101-102 - holotype of Mesocupes (Anaglyphites) clavatus (Ponomarenko, 1964), comb.n. ("PIN 2066/2275"): 101 — dry print; 102 - print covered by alcohol; Upper Jurassic, Oxfordian (or/and Kimmeridgian); Kazakhstan, Karatau; length of body $6.0 \mathrm{~mm}$; 103 - holotype of Mesocupes (Mesocupes) minor (Ponomarenko, 1968), comb.n. ("PIN 2239/812"); Upper Jurassic, Oxfordian (or/and Kimmeridgian); Kazakhstan, Karatau; dry print, length of body $4.4 \mathrm{~mm}$; 104 - additional specimen M. (M.) minor comb.n. ("PIN 2239/810"); Upper Jurassic, Oxfordian (or/and Kimmeridgian); Kazakhstan, Karatau; dry print, length of body $4.0 \mathrm{~mm}$.

Рис. 101-104. Ископаемые виды подродов Anaglyphites and Mesocupes s.str. (genus Mesocupes), сфотографированные на микроскопе Leica MZ 9.0 с камерой DFC290: 101-102 — голотип Mesocupes (Anaglyphites) clavatus (Ponomarenko, 1964), comb.n. (“PIN 2066/2275"): 101 — сухой отпечаток; 102 отпечаток, покрытый спиртом; верхняя юра, оксфордский (или/и кимериджский) яруса; Казахстан, Каратау; длина тела 6,0 мм; 103 - голотип Mesocupes (Mesocupes) minor (Ponomarenko, 1968), comb.n. (“PIN 2239/812”); верхняя юра, оксфордский (или/и кимериджский) яруса; Казахстан, Каратау; сухой отпечаток, длина тела 4,4 мм; 104 - дополнительный экземпляр M. (M.) minor comb.n. (“PIN 2239/810”); верхняя юра, оксфордский (или/и кимериджский) яруса; Казахстан, Каратау; сухой отпечаток, длина тела 4,0 мм. 

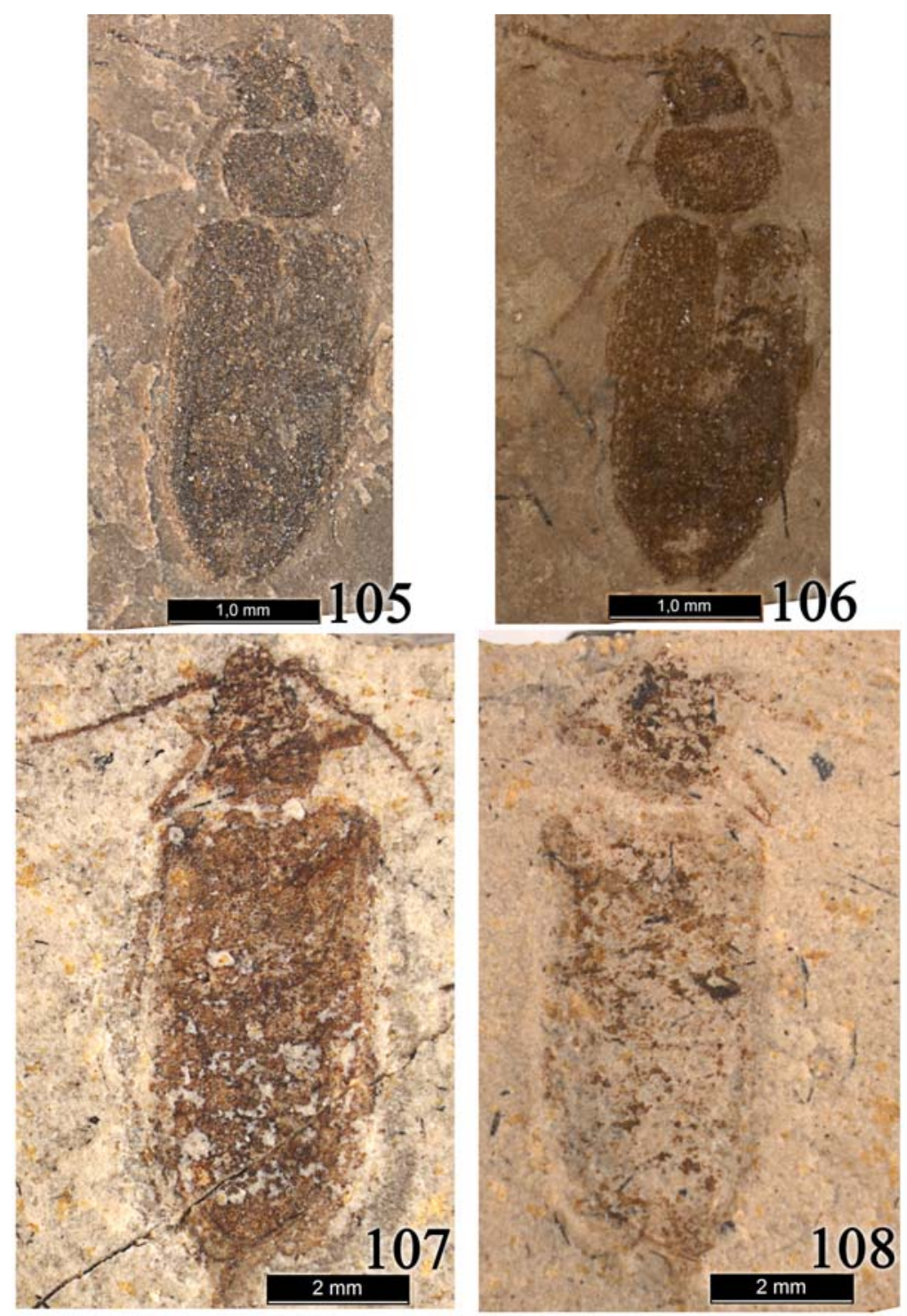

Figs 105-108. Fossil species of the subgenus Mesocupes s.str. (genus Mesocupes) and genus Cupidium, photographed under Leica MZ 9.0 with camera DFC290: 105-106 - holotype of Mesocupes (Mesocupes) paulus (Ponomarenko, 1964), comb.n. ("PIN 1789/91"): 105 - dry print; 106 - print covered by alcohol; Upper Jurassic, Oxfordian (or/and Kimmeridgian); Kazakhstan, Karatau; length of body 3.8 mm; 107-108 holotype of Cupidium abavum Ponomarenko, 1968 ("PIN 2384/398"): 107 - dry print; 108 — counterprint covered by alcohol; Upper Jurassic, Oxfordian (or/and Kimmeridgian); Kazakhstan, Karatau; length of body $9.6 \mathrm{~mm}$.

Рис. 105-108. Ископаепмые виды подрода Mesocupes s.str. (рода Mesocupes) и рода Cupidium, сфотографированные на микроскопе Leica MZ 9.0 с камерой DFC290: 105-106 - голотип Mesocupes (Mesocupes) paulus (Ponomarenko, 1964), comb.n. (“PIN 1789/91”): 105 - сухой отпечаток; 106 отпечаток, покрытый спиртом; верхняя юра, оксфордский (или/и кимериджский) яруса; Казахстан, Каратау; длина тела 3,8 мм; 107-108 — голотип Cupidium abavum Ponomarenko, 1968 ("PIN 2384/ 398"): 107 - сухой отпечаток; 108 - противоотпечаток, покрытый спиртом; верхняя юра, оксфордский (или/и кимериджский) яруса; Казахстан, Каратау; длина тела 9,6 мм. 
Cainomerga subgen.n.

(see above Diagnosis of this subgenus)

- Mesocupes (Cainomerga) brevicornis

sp.n.; Paleogene, Paleocene; France, Puy-deDome, Menat.

- Mesocupes (Cainomerga) fraternus sp.n.; Paleogene, Paleocene; France, Puy-de-Dome, Menat.

- Mesocupes (Mesocupes) immaculatus (Piton, 1940), comb.n. [Zonabris]; Paleogene, Paleocene; France, Puy-de-Dome, Menat.

- Mesocupes (Cainomerga) palaeocenicus sp.n.; Paleogene, Paleocene; France, Puy-deDome, Menat.

- Mesocupes (Cainomerga) ponti sp.n.; Paleogene, Paleocene; France, Puy-de-Dome, Menat.

Genus Miocupes Ponomarenko, 1973

This genus is quite distinct and characterized by the medium body-size (body length 12.5 $\mathrm{mm}$ ), the subparallel primary veins on the elytra without fusion at apices, nine long longitudinal rows of cells on the elytra, the very large and wide head with the comparatively small eyes, the head sides with distance from the temples to the eyes distinctly greater than that from the eyes to the anterior edge of the frons (i.e. the very long temples markedly longer than frons before the eyes), the antennal insertions rather widely separated and the insertions somewhat covered by the tubercles (convexities), the rather widely separated and subparallel gular sutures; and the transverse pronotum.

- Miocupes rihai Ponomarenko, 1973; Neogene, Middle Miocene; Czech Republic, Pochlovice near Kynsperk.

Genus Priacmopsis Ponomarenko, 1966

The large body (ca. $30 \mathrm{~mm}$ ) is the most characteristic feature of this genus (after type species - Priacmopsis adumbrata). Other characters mentioned in the original description are scarcely applicable for a reliable diagnostics, except, probably, the small subquadrate cells in the long longitudinal rows on the elytra of its type species and the pronotum which is about twice as wide as long and somewhat narrowing anteriad, and also the short antennomere 2 (pedicel). The re-examination of the holotype recovered also a distinct triangular depression on the frons which is because of its large size somewhat similar to the Y-shaped depression in some other Mesozoic cupedines. On the print of the holotype there are almost traced 10 long longitudinal rows of cells on the elytra, but on the counterprint a row of strongly transverse cells between $\mathrm{Sc}$ and lateral (true anterior) edge of the elytra is clearly visible. Besides, in contrast to other cupedines, the metacoxae of Priacmopsis adumbrata are very short, with the nearly subparallel anterior and posterior edges and very slightly extended in their mesal part forming a gentle curve along their posterior edge. This feature was erroneously drawn in the original description, as well as the shape of the metaventrite (Figs 120-121).

The second species formerly included in this taxon (Priacmopsis minimus Ponomarenko, 1997) is much smaller (body $9 \mathrm{~mm}$ ), with the pronotum much wider and apparently with larger cells. Thus this second species can be scarcely joined together with $P$. adumbrata in the same genus and it was temporaly placed into the subgenus Anaglyphites stat.n. of the genus $\mathrm{Me}$ socupes (see above).

- Priacmopsis adumbrata Ponomarenko, 1966; early Cretaceous, Middle Neocomian; Russia, Transbaikalia, Baissa.

? Genus Pulchicupes Ren, 1995

See above Latocupes Tan et Ren, 2006.

Taxopsis gen.n.

(see above Diagnosis of this genus)

- Taxopsis motschulskyi (Kirejtshuk, 2005), comb.n. [Cupes]; Paleogene, late Eocene; Baltic See coast, Russia, near Kaliningrad (formerly Königsberg), Jantarny, Baltic amber.

\subsection{List of fossil cupedine genera incertae sedis (with indefinite position)}

Genus Asimma Ponomarenko, 1966

This genus is represented by one species that seems to be very similar to those of the genus 

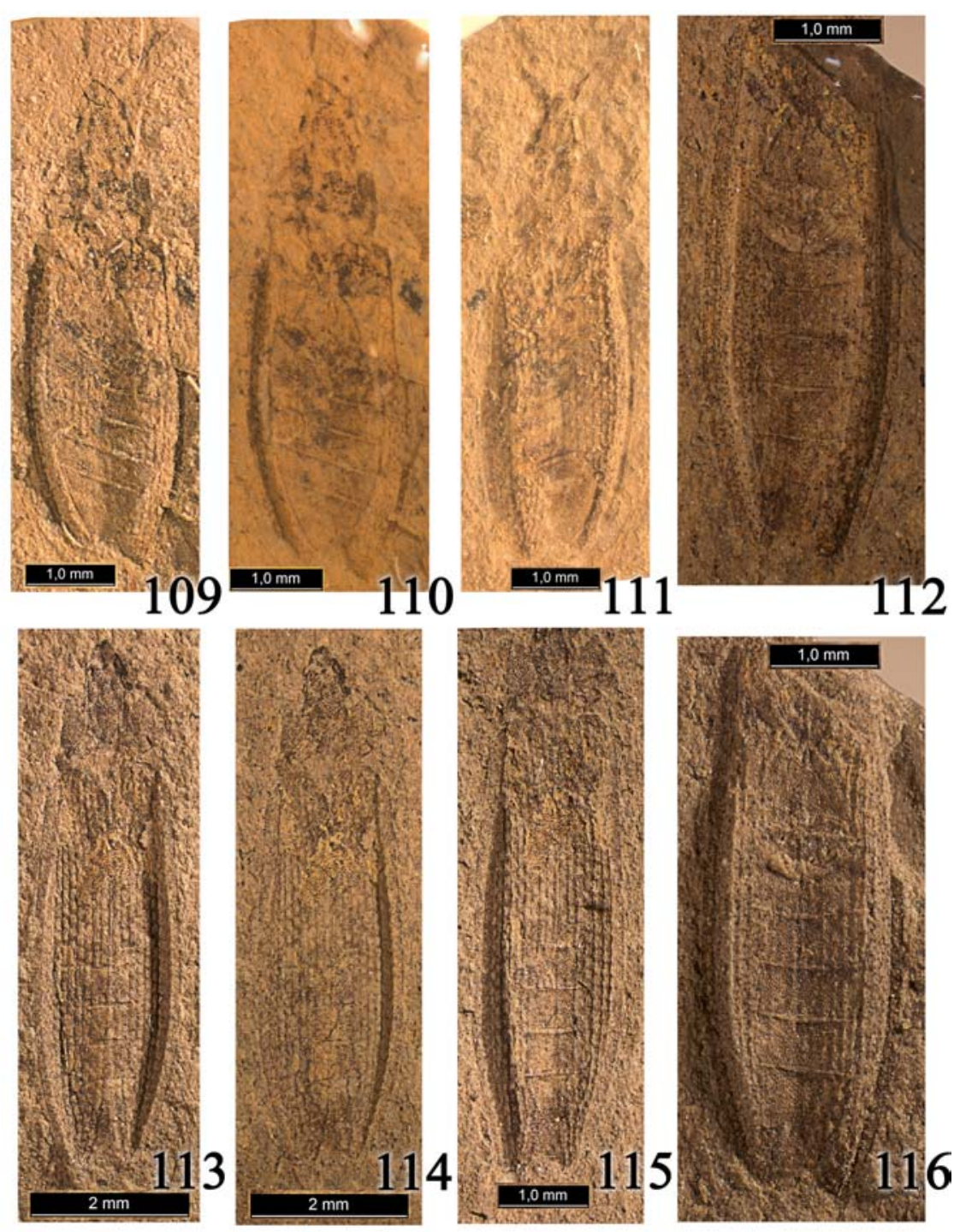

Figs 109-116. Fossil species of the genus Kirghizocupes, photographed under Leica MZ 9.0 with camera DFC290: 109-111 — holotype of K. proporeius (Ponomarenko, 1969), comb.n. ("PIN 2240/3"): 109 — dry print; 110 - print covered by alcohol, 111 — dry counterprint; ? Middle-Upper Triassic, Ladinian-Karnian; Kyrgyzstan, Osh Region, Djailaucho (Dzhayloucho), Madygen; length of body $5.8 \mathrm{~mm}$; 112 — specimen of Kirghizocupes sp. ("PIN 3064/6424", print covered by alcohol); ? Middle-Upper Triassic, LadinianKarnian; Kyrgyzstan, Osh Region, Djailaucho (Dzhayloucho), Madygen; length of beetle remains $4.5 \mathrm{~mm}$; 113-115 - holotype of Kirghizocupes indistinctus (Ponomarenko, 1969), comb.n. ("PIN 2240/72"): 113 dry print; 114 - print covered by alcohol, 115 - dry counterprint; ? Middle-Upper Triassic, LadinianKarnian; Kyrgyzstan, Osh Region, Djailaucho (Dzhayloucho), Madygen; length of body 7.5 mm; 116 specimen of Kirghizocupes sp. ("PIN 3064/6424", dry counterprint), length of beetle remains $5.9 \mathrm{~mm}$.

Рис. 109-116. Ископаемые виды рода Kirghizocupes, сфотографированные на микроскопе Leica MZ 9.0 с камерой DFC290: 109-111 - голотип K. proporeius (Ponomarenko, 1969), comb.n. ("PIN 2240/ 3"): 109 - сухой отпечаток; 110 - отпечаток, покрытый спиртом, 111 - сухой противоотпечаток; ? средний-верхний триас, Ладинский-Карнийский яруса; Киргизстан, Ошская обл., Джайляучо, Мадыген; длина тела 5,8 мм; 112 — экземпляр Kirghizocupes sp. (“PIN 3064/6424”, отпечаток, 


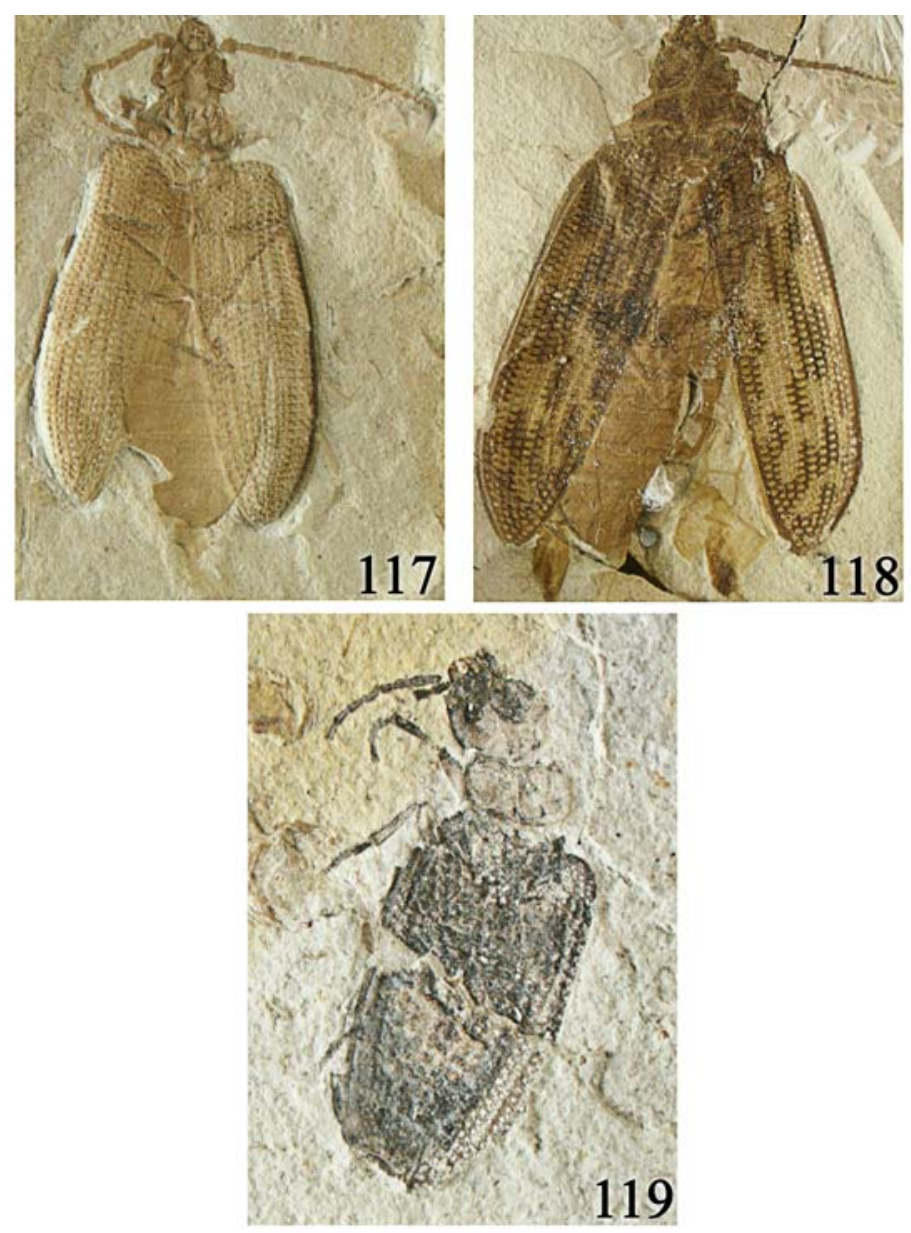

Figs 117-119. Fossil species of the genus Latocupes, photographed under Leica MZ 12.5 with camera Nikon Digital Camera DXM1200C: 117 - holotype of L.s bellus Tan et Ren, 2006 (“CNU-C-LB2005013", dry print); Lower Cretaceous, Yixian Formation; China, Liaoning, Beipiao; length of body $12.7 \mathrm{~mm}$; 118 holotype of . fortis Tan et Ren, 2006 ("CNU-C-LB2005012", dry print); Lower Cretaceous, Yixian Formation; China, Liaoning, Beipiao; length of body $27.5 \mathrm{~mm}$; 119 — ? holotype of L.s collaris (Tan, Huang et Ren, 2006), comb.n. (? "NIGPAS 142147”, found in collection of CNU without number); Middle Jurassic, Jiulongshan Formation; Inner Mongolia; Chifeng City, Daohugou; dry print; length of body $13.3 \mathrm{~mm}$.

Рис. 117-119. Ископаемые виды рода Latocupes, сфотографированные на микроскопе Leica MZ 12.5 с камерой Nikon Digital Camera DXM1200C: 117 — голотип L. bellus Tan et Ren, 2006 ("CNU-CLB2005013”, сухой отпечаток); нижний мел, формация исянь; Китай, Ляонинь, Бейпяо; длина тела 12,7 мм; 118 - голотип L. fortis Tan et Ren, 2006 (“CNU-C-LB2005012”, сухой отпечаток); нижний мел, формация исянь; Китай, Ляонинь, Бейпяо; длина тела 27,5 мм; 119 - ? голотип L. collaris (Tan, Huang et Ren, 2006), comb.n. (? “NIGPAS 142147”, найден в коллекции CNU без номера); средняя юра, формация Джулиньшан; Внутренняя Монголия; Чифен, Даохугоу; сухой отпечаток; длина тела 13,3 мм.

покрытый спиртом); ? средний-верхний триас, Ладинский-Карнийский яруса; Киргизстан, Ошская обл., Джайляучо, Мадыген; длина остатков жука 4,5 мм; 113-115 - голотип Kirghizocupes indistinctus (Ponomarenko, 1969), comb.n. (“PIN 2240/72"): 113 - сухой отпечаток; 114 - отпечаток, покрытый спиртом, 115 - сухой противоотпечаток; ? средний-верхний триас, Ладинский-Карнийский яруса; Киргизстан, Ошская обл., Джайляучо, Мадыген; длина тела 7,5 мм; 116 - экземпляр Kirghizocupes sp. (“PIN 3064/6424”, сухой противоотпечаток), длина остатков жука 5,9 мм. 

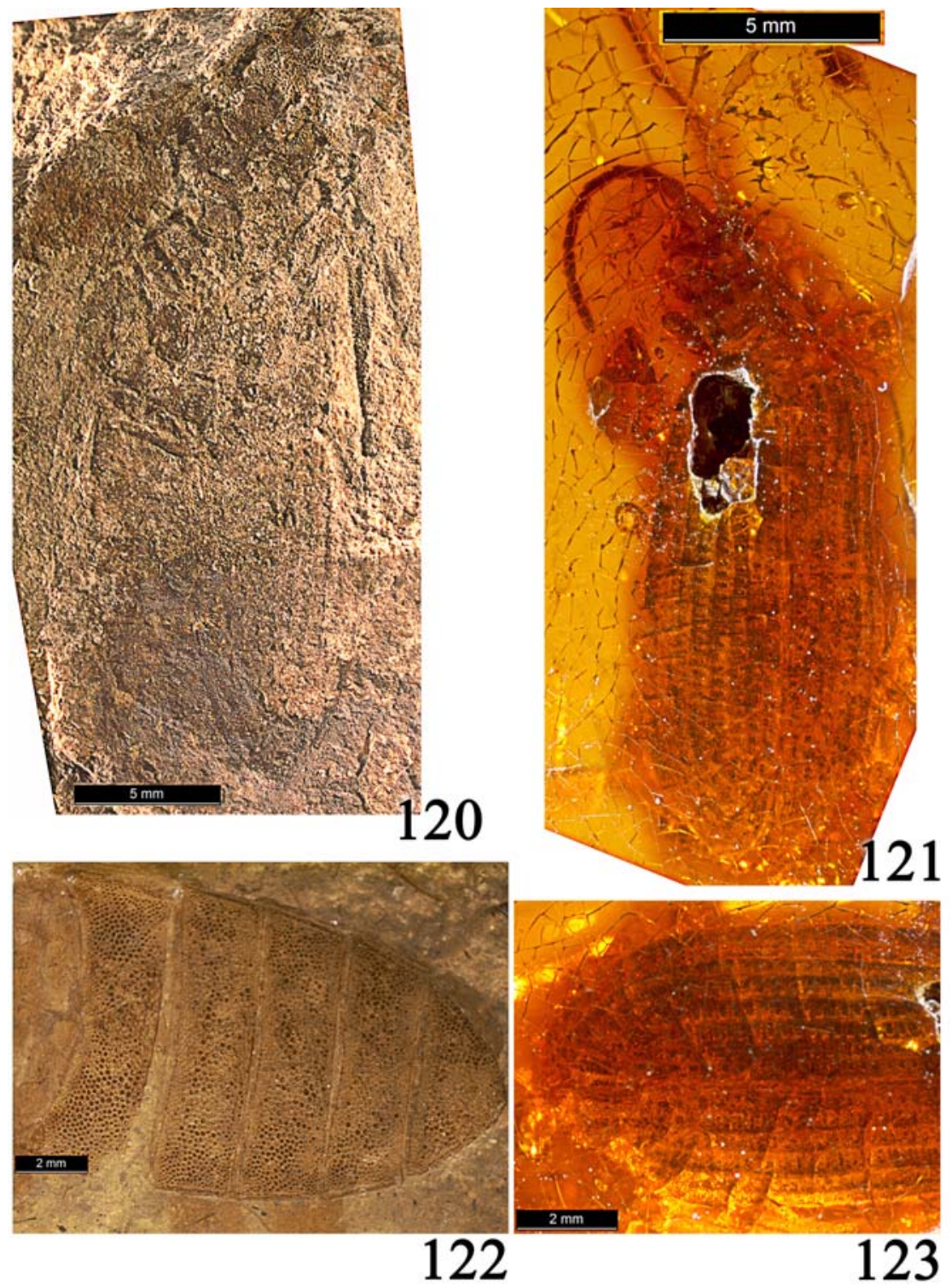

Figs 120-123. Fossil species of the subfamily Cupedinae, photographed under Leica MZ 9.0 with camera DFC290: 120 - holotype of Priacmopsis adumbrata Ponomarenko, 1966 ("PIN 1989/3000"); Lower Cretaceous, Middle Neocomian; Russia, Transbaikalia, Baissa; dry print, length of specimen $30 \mathrm{~mm}$; 121 additional specimen of $P$. adumbrata ("PIN 1989/3032"), print under alcohol; 122 - holotype of Taxopsis motschulskyi Kirejtshuk, 2005, comb.n. ("PIN 363/130"); Paleogene, Upper Eocene; Russia, Jantarny, Baltic amber; body, dorsal; 123 - idem, elytral apices, length of body $16.1 \mathrm{~mm}$.

Рис. 120-123. Ископаемые виды подсем. Cupedinae, сфотографированные на микроскопе Leica MZ 9.0 с камерой DFC290: 120 — голотип Priacmopsis adumbrata Ponomarenko, 1966 ("PIN 1989/3000"); нижний мел, средний неоком; Россия, Забайкалье, Бурятия, Байса; сухой отпечаток; длина экземпляра 30 мм; 121 — дополнительный экземпляр P. adumbrata (“PIN 1989/3032"), отпечаток, покрытый спиртом; 122 - голотип Taxopsis motschulskyi Kirejtshuk, 2005, comb.n. (“PIN 363/130"); палеоген, верхний эоцен; Россия, Янтарный, балтийский янтарь; тело, сверху; 123 - то же, вершины надкрылий, длина тела 16,1 мм. 
Kirghizocupes by many characters including the structure of pterothorax, the elytra probably with 10 long longitudinal rows of cells and without fusion of veins at apices. However, it is differing mostly in the somewhat more slender body and the pronotal sides less widely explanate. Unfortunately the head of the remains of the type species of this genus is missing and structure of underside of prothoracic segment is not clear. To clarify the position of this genus it is necessary to redescribe the holotype of this type species.

- Asimma rara Ponomarenko, 1966; ? Middle-late Triassic, Ladinian-Karnian; Kyrgyzstan, Osh Region, Djailaucho (Dzhayloucho), Madygen.

\section{Genus Ensicupes Hong, 1976}

This genus seems to be a member of Cupedidae, although it was described as Taldycupedidae, because the print with the holotype of its type species (Ensicupes guyanensis: elytron $13.2 \mathrm{~mm}$ long) shows the characteristic features in the polygonal cells arranged into not clear long longitudinal rows and weakly raised primary veins with the fusion of $\mathrm{A} 1$ and $\mathrm{CuA}$ characteristic of Cupedinae. However it has not any more definite character for definion on its position in this subfamily.

- Ensicupes guyanensis Hong, 1976; early Cretaceous, Aptian, Guyang Formation; China, Guyang County, Houmachi;

- Ensicupes obtusus Zhang, 1997; early Cretaceous, Dalazi Formation; China, Jilin Province, Zhixin Basin.

Genus Pterocupes Ponomarenko, 1966

This genus is represented by two species. The type species of it (P. antennatus) seems to be very similar to those in Asimma and Kirghizocupes with the elytra having steeply sloping and sharply inflected sides, however its head, in contrast to that of the latter, is markedly shorter. Another species of the genus (P. leptocerus) is represented by the remains of a specimen that apparently was much more robust than those of the type species, with the strongly transverse head and the wider elytra with not sharp (obliterated) inflection of elytral sides outwards from the seventh row of cells. Therefore, if the holotype of $P$. leptocerus was not deformed by fossilization, it should be considered as member of another genus. To clarify the position of this genus it is necessary to reexamine the holotypes of both species.

- Pterocupes antennatus Ponomarenko, 1966; ? Middle-late Triassic, Ladinian-Karnian; Kyrgyzstan, Osh Region, Djailaucho (Dzhayloucho), Madygen.

- (?) Pterocupes leptocerus Ponomarenko, 1966; ? Middle-late Triassic, Ladinian-Karnian; Kyrgyzstan, Osh Region, Djailaucho (Dzhayloucho), Madygen.

\subsection{List of fossil cupedine species without generic attribution}

- 'Priacma' sanzii Soriano et Delclós 2006; early Cretaceous, Barremian; Spain, Cuenca, 4 $\mathrm{km}$ NE from village Cierva, Las Hoyas.

The remains of the holotype show the very different characters from those of both Cupes and Priacma (Kirejtshuk et al., 2010), particularly concerning the shape of the pronotum with the truncate anterior edge and the rounded sides, the sculpture of elytra, and the very short antennae. Therefore, this species should be regarded as an "incertae sedis" among the Cupedinae till a further re-examination of the type specimen.

- '?Anaglyphites' pluricavus Soriano et Delclós, 2006; early Cretaceous, early Barremian; Spain, Ilerda, La Cabrua, Montsec Range, Montsec.

In the description of this species there is no clear diagnostic character usable for generic attribution. However, at least the narrowly separated and open posteriorly procoxal cavities can indicate that this species could be regarded as a member of Cupedinae.

- '?Platycupes' sogdianus Ponomarenko, 1966; ? Middle-late Triassic, Ladinian-Karnian; Kyrgyzstan, Osh Region, Djailaucho (Dzhayloucho), Madygen.

This species is rather different from the type species of the genus Platycupes due to its rather slender body. It is also characterized by the 
comparatively narrowly separated procoxae and 10 long longitudinal rows of large subquadrangular cells (without expressed primary veins) on elytra. To clarify the position of this species, it is necessary to re-examine the holotype of it.

\subsection{List of fossil cupedid genera incertae} sedis (uncertain or corrected subfamily), not Cupedinae or doubtful members of Archostemata

Genus Anthocoleus Hong, 1983

The type species of this genus is represented by a narrow elytron ( $12 \mathrm{~mm}$ long). It has more or less clear 10 long longitudinal rows of irregular large cells and not raised primary veins. This taxon was proposed as a member of Taldycupedidae, however it could belong to a cupedid group, although its subfamily attribution is impossible to define with certainty.

- Anthocoleus hebeiensis Hong, 1983 (Taldycupedidae); Middle Jurassic, Callovian/Oxfordian, Jiulongshan Formation; China, Luoping County, Zhouyingzi village.

Genus Argentinocupes Martins-Neto et Gallego in Martins-Neto et al., 2006

This genus was proposed for the elytra with outlines of 2.5-9.3 mm long initially put in the family Cupedidae (Martins-Neto et al., 2006a, b). They are characterized by nine long longitudinal rows of very large cells and weakly expressed primary veins. Ponomarenko regards that these elytra could belong to Permocupedidae (Kirejtshuk, Ponomarenko, 2016), but to clarify the position of this genus it would be necessary to re-examine the accessible materials.

- Argentinocupes pulcher Martins-Neto et Gallego in Martins-Neto et al., 2006; late Triassic, Los Rastros Formation; Argentina, La Rioja Province, Río Gualo;

- Argentinocupes abdalai Martins-Neto et Gallego in Martins-Neto et al., 2006; late Triassic, Los Rastros Formation; Argentina, La Rioja Province, Río Gualo.

Genus Bothynophora Heer, 1865

This genus is a member of Cupedidae (unless Taldycupedidae), as the print with the holo- type (elytron) of its type species shows the characteristic features in cells arranged into the long longitudinal rows. It is also characterized by the unraised primary veins, without clear fusion of them at apex. However the subfamilial position of this genus is uncertain at the moment.

- Bothynophora elegans Heer, 1865 (Oedemeridae); Middle Eocene; Germany, near Halle, Geiseltal.

\section{Genus Celocoleus Hong, 1983}

The type species of this genus is represented by one narrow elytron (11 mm long) and has more than 10 unclear long longitudinal rows of the irregular large cells and not raised primary veins. It was proposed as a member of Taldycupedidae, however it could belong to a cupedid group, although the subfamily attribution of it is scarcely possible to define.

- Celocoleus densus Hong, 1983 (Taldycupedidae); Middle/late Jurassic, Callovian/Oxfordian, Jiulongshan Formation; China, Luoping County, Zhouyingzi village.

\section{Genus Chengdecupes Hong, 1983}

This genus was proposed for the almost complete specimen ( $22.0 \mathrm{~mm}$ long) initially put in the family Cupedidae. The type species (Chengdecupes jurassicus) has the subtriangular metacoxae and the large cells on elytra arranged in 9 or 10 long longitudinal rows on the elytra which are very characteristic of many cupedines. The rather short metaventrite, apparently the (sub) contiguous procoxae (if they were correctly drawn by the descriptor), the steeply sloping elytral sides and the weakly raised primary veins with the fusion of $\mathrm{A} 1$ and $\mathrm{CuA}$ before apex make it possible to suppose the attribution of this genus to the Ommatinae. Probably three species described as members of this genus belong to different generic groups. In particular, Chengdecupes kezuoense is represented by the elytral apex with the clear large cells and the well expressed primary veins which have a pattern apparently characteristic of the species of Notocupes (Ommatinae) rather than that of other cupedids. 
- Chengdecupes jurassicus Hong, 1983; Middle/late Jurassic, Callovian/Oxfordian Jiulongshan Formation; China, Hebei, Chengde, Xiaofanzhangzi (? Tongchuan Formation; China, Shanxi, Shiluo);

- Chengdecupes kezuoense Hong, 1987; early Cretaceous, Shahai Formation; China, Liaoning, Xiwan village, Meileyingzi, Kezuo;

- Chengdecupes shiluoense Hong, 1984; Middle Triassic, Tongchuan Formation; China, Shilou County, Mengjiachang.

Genus Clathrocupes Hong, 1980

The type species of this genus was initially attributed to Taldycupedidae. However the characters in the original description do not make it possible to conclude whether it belongs to $\mathrm{Cu}$ pedidae or to any other Mesozoic archostematan family. Although the large cells on the elytra arranged in the long longitudinal rows without clear primary veins and without fusion at apices as well as with the comparatively wide elytral "epipleura" have some similarity with those in Triadocupedinae, six abdominal ventrites drawn in the original description do not give a reason to include it in Cupedidae.

- Clathrocupes anthrilegnotos Hong, 1980; Middle Triassic, Tongchuan Formation; China, Shanxi Province, Schiluo, Mengjiachang.

Genus Cupedites Ponomarenko, 1985

This "formal" genus in the family Cupedidae was proposed for the small elytra (1.8-2.2 $\mathrm{mm}$ long) characterized by the well raised and (sub) parallel primary veins reaching their lateral edge without fusion and elongately oblong cells between them. The subfamily attribution of this species (the type species, ! by monotypy) is questionable, however, the available characters are enough to compare this supraspecific taxon with other cupedid genera and subgenera.

- Cupedites minutissimus Ponomarenko, 1985; early Jurassic, Makarovskaya Formation; Siberia, Krasnoyarsky Kray, Krasnoyarsk (Tatyshev Island).

Genus Doggeriopsis Handlirsch, 1906

This genus seems to be a member of Cupedidae or Taldycupedidae, as the print with the holotype of its type species (comparatively wide elytron with length $19 \mathrm{~mm}$ ) shows the characteristic features in the cells arranged into clear long longitudinal rows [it was drawn by Buckland (1837) as Buprestis sp.]. It seems to be also characterized by the absence of difference in development in the primary and secondary veins and the absence of clear fusion of them at apex. However this genus is scarcely can be linked with any subfamily without re-examination of the type specimen.

- Doggeriopsis stonefieldiana Handlirsch, 1906; Middle Jurassic, Dogger, Taunton Limestone Formation; England, Oxfordshire, Stonesfield Slate.

Genus Eumecoleus Haupt, 1950

This genus was proposed for the elytra with the outlines of $12 \mathrm{~mm}$ long placed in Oedemeridae and compared with the sculpture Cupedidae. Hörnschemeyer et al. (1995) considered them as probable archostematan, although, except two striae along the middle of the distal half that somewhat resemble the primary veins A1 and $\mathrm{Cu}$ in the cupedines, these prints have not any character which can be used for definition of their family or suborder attribution, although its most probable placement could be among cupedids.

- Eumecoleus tenuis Haupt, 1950 (Oedemeridae); Middle Eocene; Germany, near Halle, Geiseltal.

Genus Euteticoleus Hong, 1983

(=Eutecticoleus Hong, 1983; Eutecticupes Hong, 1983)

The type species of this genus is represented by one comparatively large and narrow elytron ( $8.5 \mathrm{~mm}$ long) and has more or less clear 10 long longitudinal rows of the irregular large cells and not raised primary veins. It was initially proposed as a member of Taldycupedidae, however it could belong to a cupedid group, but a subfamily attribution of it is scarcely possible to define.

- Euteticoleus radiatus Hong, 1983 (Taldycupedidae); Middle Jurassic, Callovian/Oxfordian, Jiulongshan Formation; China, Chengde City, Xiaofanzhangzi. 
Genus Gansucupes Hong, 1982

The type species is represented by one narrow elytron $10.0 \mathrm{~mm}$ long and $2.3 \mathrm{~mm}$ wide as a member of Cupedidae. The photograph of this elytron shows four primary veins (but the original drawing is with five veins) with the characteristic cells arranged in 10 long longitudinal rows, although $\mathrm{A} 1$ and $\mathrm{CuA}$ are not distinct and the primary veins at elytral apex are becoming unclear (without visible fusion). This elytron seems to be somewhat similar to that of $\mathrm{Cu}$ pedites minutissimus and could belong to Cupedinae or Ommatinae due to comparatively large oval to polygonal cells.

- Gansucupes attenuatus Hong, 1982; early Cretaceous, Barremian, Chijinqiao Formation; China, Gansu Province, Yumen, Chijinqiao (Jiuquan).

\section{Genus Hebeicoleus Hong, 1992}

This genus can be a member of Cupedidae or Taldycupedidae, as the print with the holotype (elytron of $8.5 \mathrm{~mm}$ long) of its type species shows the characteristic features in the cells arranged into the long longitudinal rows. It is also characterized by the unraised primary veins, the absence of clear fusion at apex and particularly by the strongly transverse cells on the elytral disk (as those in Latocupes and Taxopsis gen.n.). However the subfamily attribution of this genus remains uncertain without re-examination of the type specimen.

- Hebeicoleus sertulatus Hong, 1992; Middle Jurassic, Jiulongshan Formation; China, Hebei, Chengde, Donggou village.

\section{Genus Hebeicupes Zhang, 1986}

This genus seems to be a member of Cupedidae, as the the holotype of its type species (complete robust body of $9.3 \mathrm{~mm}$ long, with the rather wide pronotum and the short elytra) shows the characteristic features in the oval cells arranged into not clear long longitudinal rows and the absence of clearly raised veins. To prove its family attribution a further re-examination of the type specimen is required.

- Hebeicupes formidabilis Zhang, 1986; Middle/late Jurassic, Callovian/Oxfordian, Jiu- longshan Formation; China, Luoping County, Zhouyingzi village.

\section{Genus Helopides Roemer, 1876}

The type species of this genus was described after the study of one separate elytron as similar to that in Helops Fabricius, 1775 (Tenebrionidae Latreille, 1802) and showing the characteristic cupedid venation and cellulation with somewhat expressed primary veins, the fusion of $\mathrm{A} 1$ and $\mathrm{CuA}$ and the characteristic prescutellar concentration of cells isolated by A2. At this moment it is impossible to make any conclusion about the subfamily attribution of this genus.

- Helopides hildsiensis Roemer, 1876; late Triassic; Germany, Niedersachsen (Kraelaeh near Hildesheim.

Genus Ironicus Handlirsch, 1906

(= Harpalidium Westwood, 1854)

The name Harpalidium nothus was proposed for a species represented by one elytron (10 mm long) which seems to have sculpture somewhat looking like that in Cupes due to the long longitudinal rows of large "cells", although as it can be seen in the original drawing (Westwood, 1854: pl. 17, Fig. 3) the interspaces between the "cells" are obliterated (somewhat like that in Chalepocarabus). Handlirsch(19061908) proposed for this genus a new name Ironicus, probably because "hat nichts mit Harpalus gemein" [Handlirsch, 1906 (1906-1908): 559] and also because the generic name Harpalidium was used for another very different species in the same publication (Westwood, 1854: Harpalidium anactus: 393 and pl. 14, Fig.20) without designation of type species for the proposed taxon. Later the junior homonym was proposed (Harpalidium Kolbe, 1883), which, in turn, is regarded as a junior synonym of Siopelus Murray, 1859 (Carabidae). Indeed the possible affiliation of this fossil genus to Cupedidae is also still unclear. This confusing situation could be solved after a further re-examination of the type specimen.

- Ironicus nothus (Westwood, 1854) [Harpalidium ]; early Cretaceous, Berriasian, Purbeck Limestone Formation; England, Dorset, Durlston Bay near Swanedge. 
Genus Katapontisus Handlirsch, 1906

The holotype of the type species (fragment of apical part of elytron of $2 \mathrm{~mm}$ long) was mentioned and drew by Brodie (1845: pl. 6, Fig. 9) as Limnius (?) sp. Later Giebel (1856) proposed for it the name Elmis brodiei, and, finally, Handlirsch (1906-1908) erected for this species a separate genus with an unclear family attribution. The fragment of the elytron demonstrates the large cells and some traces of veins, including the fusion of $\mathrm{A} 1$ and $\mathrm{CuA}$ characteristic of Cupedidae, however is scarcely possible to define a subfamily attribution of this species.

- Katapontisus brodiei (Giebel, 1856) [Elmis]; early Cretaceous, Berriasian, Lulworth Formation; England, Wiltshire, Dinton, Vale of Wardour.

Genus Kelidus Handlirsch, 1906

(=Buprestium Westwood, 1854)

The name Buprestium bolbus was proposed for a species represented by one elytron $(5 \mathrm{~mm}$ long) which seems to have sculpture somewhat looking like that in Cupes due to the long longitudinal rows of large "cells". As it can be seen in the original drawing (Westwood, 1854: pl. 17, Fig. 5) and in Handlirsch (1906-1908: pl. 45, Fig. 46) the interspaces between the "cells" are without clear primary veins, although the fusion of $\mathrm{A} 1$ and $\mathrm{CuA}$ is traceable (at least in the disposition of cells). Handlirsch (1906-1908) proposed for this genus a new name Kelidus, probably because of "ist nichts sicher als Buprestide zu erkennen" [Handlirsch, 1906(19061908): 557] and also because the generic name Buprestium was used for some different species in the same publication (Westwood, 1854: $B u$ prestium dardanus, B. stygnus, B. taleas, $B$. valgus and $B$. woodlei) without designation of type species for this used taxon. Unfortunately the subfamily attribution of this fossil species is scarcely possible even after a re-examination of the type specimen, although some probability of its link to cupedids can be supposed.

- Kelidus bolbus (Westwood, 1854) [Buprestium]; early Cretaceous, Berriasian, Lulworth Formation; England, Dorset, Swanage/ Purbeck.

\section{Genus Lecanopteryx Haupt, 1950}

This genus was proposed for the elytra with outlines of $10 \mathrm{~mm}$ long having neither any trace of venation and cells nor another character which can be used for definition of their family attribution. Hörnschemeyer et al. (1995) considered them as probable archostematan, although, except general outline looking like somewhat similar to that in cupedines, these prints have not any character which can be used for definition of their family attribution.

- Lecanopteryx miranda Haupt, $1950(\mathrm{Cu}-$ pedidae); Middle Eocene; Germany, near Halle, Geiseltal.

Genus Liassocupes Zeuner, 1962

This genus with two species is re-interpreted in the composition of Ommatinae after re-examination of the type species of the genus (Liassocupes parvus Zeuner, 1962) (Ponomarenko, 2006). Besides, Liassocupes gigantea Whalley, 1985 in the latter publication was transferred into the genus Mimema Handlirsch, 1906 (Schizocoleidae) (Ponomarenko, 2006). However the position of two other species needs to be clarified after a further re-examination their type materials. Hubert et al. (2003) identified one elytron from New Jersey (U.S.A.) as "Liassocupes parvus", but it would be better to regard it without subfamily and generic attribution (see below Chapter 8.5).

- Liassocupes maculatus Whalley, 1985; early Jurassic, Sinemurian; England, Dorset, Stonebarow, Charmouth;

- Liassocupes parvus Zeuner, 1962; early Jurassic, Sinemurian; England, Dorset, Stonebarow, Charmouth.

\section{Genus Longaevicupes Ren, 1995}

This taxon is traditionally regarded as a junior synonym of Tetraphalerus (Kirejtshuk, Ponomarenko, 2016), although it was proposed as a member of the Taldycupedidae Rohdendorf, 1861. However, the remains of the holotype of the type species of this genus are $8 \mathrm{~mm}$ long and represented by the elytra with nine long longitudinal rows of cells, the pterothorax and the abdomen similar to those of the slender 
cupedines rather than to slender ommatines. It particularly concerns the outline of the elytra. Its very important features are expressed in the weak primary veins combining with the fusion of $\mathrm{A} 1$ and $\mathrm{CuA}$ at elytral apex, which are more characteristic of various cupedines, but not Tetraphalerus. The very wide metepisterna of this species are rather unique among members of the family Cupedidae at all.

-Longaevicupes macilentus Ren, 1995; early Cretaceous, Aptian, Lushangfen Formation; China, Western Beijing Province, Jingxi Basin, Lushangfen village.

\section{Genus Lupicupes Ren, 1995}

According to the original description the remains of this species (holotype of $16 \mathrm{~mm}$ long and exposing the elytra, meso- and metatibiae, and abdomen) demonstrate 12 (or not less than 11) long longitudinal rows of strongly transverse cells on the elytra. The primary elytral veins of this specimen are more or less distinct and showing the fusion of $\mathrm{A} 1$ and $\mathrm{M}$ while $\mathrm{CuA}$ is diappearing between these veins. This generic name was recently synonymized with Notocupes without argumentation (Ponomarenko, 2006). However it is difficult to be sure whether Lupicupes trachylenus Ren, 1995 belongs to Cupedinae or Ommatinae, although its elytra with the strongly transverse cells seem to be similar to those in Latocupes, Mesothoris and Pulchicupes (see above) rather than any other cupedids.

- Lupicupes trachylenus Ren, 1995; early Cretaceous, Aptian, Lushangfen Formation; China, Western Beijing Province, Jingxi Basin, Lushangfen village.

\section{Genus Mesothoris Tillyard, 1916}

This genus was proposed for the elytron named Mesothoris clathrata Tillyard, 1916 (type species, monotypy), which Tillyard regarded as resembling "Thoris" Pascoe, 1867 (Cerambycidae Latreille, 1802) and compared it also with Omma (Tillyard, Dunstan, 1916). This elytron demonstrates 10 long longitudinal rows of the subquadrangular cells and unclear primary veins characteristic of Cupedidae. Later Dunstan
(1923) added to this genus three additional species (M. grandis Dunstan, 1923, M. quadripartite Dunstan, 1923 and M. tenuiclathrata Dunstan, 1923). The remains of the first species include the part of elytron with 10 long longitudinal rows of the strongly transverse cells and unclear primary veins, pterothorax and abdomen. This species (M. grandis) could be regarded as a member of the same genus. However, Mesothoris tenuiclathrata and M. quadripartite have much greater number of long longitudinal rows and could be transfered to the genus Mesolobites Carpenter, 1985 (= Lobites Dunstan, 1923, non Mojsisovics, 1873) of the family Schizocoleidae Rohdendorf, 1961 (Kirejtshuk, Ponomarenko, 2016). Another species was described after a separate elytron as a members of the genus Elaterium Westwood, 1854 (E. punctomarginum Dunstan, 1923) with 11 long longitudinal rows of cells, including one row placed along explanate stripe of the elytral side. Riek (1968) described a further species in this genus, Mesothoris westraliensis Riek, 1968, and put it in the family Tenebrionidae. This species together with M. clathrata and M. grandis instead of their differences in structure of elytra are here preliminarily regarded as cupedids with unclear position (Cupedinae or Ommatinae). These attributions are confirmed by the pictures of the type specimens published by Jell (2004).

- Mesothoris clathrata Tillyard, 1916; late Triassic, Carnian; Australia, Queensland, Denmark Hill.

- Mesothoris grandis Dunstan, 1923; late Triassic, Carnian; Australia, Queensland, Denmark Hill.

- Mesothoris punctomarginum (Dunstan, 1923), comb.n. [Elaterium]; late Triassic, Carnian; Australia, Queensland, Denmark Hill.

- Mesothoris westraliensis Riek, 1968; late Triassic; Australia, West Australia, Hill River.

Genus Mesotricupes Hong, 1982

Two species of this genus are represented by the medium-sized elytra about $5 \mathrm{~mm}$ long and 2 $\mathrm{mm}$ wide described as members of Cupedidae. The photograph of the elytron of the type spe- 
cies (Mesotricupes lineatus) shows three apparently convex narrow stripes looking like primary veins not fused but converging at the apex and with probable sculpture between them apparently consisting of small diffuse cells. The character of the "venation" of these elytra seems to be somewhat similar to that in some members of Tricoleidae Ponomarenko, 1969, although their sculpture between "primary veins" is completely different, and, therefore, it would be reasonable to temporarily consider them without suborder attribution.

- Mesotricupes lineatus Hong, 1982; early Cretaceous, Aptian, Chijinpu Formation; China, Gansu Province, Yumen, Chenjiwan, Changma;

- Mesotricupes reticulatus Hong, 1982; early Cretaceous, Aptian, Xiagou Formation; China, Gansu Province, Yumen, Chenjiwan, Changma.

\section{Genus Metacupes Gardiner, 1961}

The type species of this genus is represented by six fragments (five pieces of elytra and one piece of metaventrite) having no clear diagnostic character to identify their family and genus. The large punctures or cells on elytra arranged in the long longitudinal rows could make it possible to suppose a link of this species with any group of Archostemata, however the these punctures or cells have circular outlines in the drawing giving rise to doubt that they could be really archostematan cells.

- Metacupes harrisi Gardiner, 1961; late Triassic - early Jurassic, Rhaetian; England, near Bridgend (Cnap Twt quarry, St. Bride's Island).

\section{Genus Nannocurculionites Handlirsch, 1906}

The type species of this genus was described in the composition of the genus Curculionites Heer, 1847, nec Kolbe, 1888 (Curculionidae Latreille, 1802). It is represented by the part of one elytron (1.7 mm long) showing characteristic cellulation and venation with the expressed primary veins with the fusion of $\mathrm{A} 1$ and $\mathrm{CuA}$. This elytron could belong to a member of Cupedidae (Cupedinae or Ommatinae).
- Nannocurculionites carlsoni (Heer, 1878) [Curculionites]; late Triassic; Sweden, Scania, Rhaetian Bjuf.

Genus Parabuprestites Handlirsch, 1906

The type species of this genus was described in the composition of the genus Buprestites (Buprestidae Leach, 1815). It is represented by the part of one elytron (3.0 mm long) showing characteristic cellulation and venation with the expressed primary veins and the fusion of A1 and $\mathrm{CuA}$ which are somewhat similar to that in Nannocurculionites carlsoni (see above). This elytron could belong to a member of Cupedidae (Cupedinae or Ommatinae).

- Parabuprestites rugulosus (Heer, 1878) [Buprestites]; late Triassic; Sweden, Scania, Rhaetian Bjuf.

Genus Paracurculionites Handlirsch, 1906

The type species of this genus was initially described in the composition of the genus Curculionites (Curculionidae). It is represented by the part of one elytron (3.0 mm long) showing the characteristic cellulation and venation with somewhat expressed primary veins and the fusion of $\mathrm{A} 1$ and $\mathrm{CuA}$. This elytron could belong to a member of Cupedidae (Cupedinae or Ommatinae).

- Paracurculionites parvulus (Heer, 1878) [Curculionites]; late Triassic; Sweden, Scania, North of Sofiero.

Genus Paradoggeria Handlirsch, 1906

This genus is a member of Cupedidae or Taldycupedidae, as the holotype (moderately narrow elytron of $16 \mathrm{~mm}$ long) of its type species shows the characteristic features in the cells arranged into the clear long longitudinal rows [it was drawn by Buckland (1837) as Buprestis sp.]. It seems to be also characterized by the absence of difference in development in the primary and secondary veins and the absence of clear fusion of them at apex. However this genus is scarcely can be linked with any subfamily without re-examination of the type specimen.

- Paradoggeria acuminata Handlirsch, 1906; Middle Jurassic, Dogger, Taunton Limestone Formation; England, Oxfordshire, Stonesfield Slate. 
Genus Petalocupes Hong, 1982

The type species of this genus described as a member of Cupedidae is represented by a small and narrow elytron about $4 \mathrm{~mm}$ long and $1 \mathrm{~mm}$ wide. The photographs of this elytron are not clear and the drawings show four elongate convex narrow stripes looking somewhat like primary veins and not fused but convergent at apex; and the sculpture between them consists of small and irregular (frequently transverse) diffuse cells. To clarify its family and suborder attribution a further re-examination of the type specimen is necessary.

- Petalocupes arcus Hong, 1982; early Cretaceous, Aptian, Xiagou Formation; China, Gansu Province, Yumen, Xiagou City, Qingquan.

\section{Genus Pseudosilphites Zeuner, 1930}

The type species of this genus is represented by the elytra ( $8.2 \mathrm{~mm}$ long) with strongly raised primary veins and characteristic fusion of A1 and $\mathrm{CuA}$ before apices, which suggests an attribution to the Cupedinae or Ommatinae (in the original description, it was compared with Silpha Linneus, 1758, Silphidae Latreille, 1807).

- Pseudosilphites triassicus Zeuner, 1930 (Silphidae); Middle Triassic; Germany, Nordrhein-Westfallen, "Strasse Vlotto-Bonneberg".

- Pseudosilphites natalensis Zeuner, 1960 (Silphidae); Middle Triassic; Molteno beds, South Africa.

Genus Stigmenamma Handlirsch, 1906

The type species of this genus is represented by the elytron about $9.5 \mathrm{~mm}$ long described as a member of Harpalus by Giebel (1956) and figured before by Brodie (1945), who also mentioned that this elytron has "pale elytra with dark brown markings". The elytron bears 9-10 long longitudinal subparallel rows of large cells and no clear vein. It very probably belongs to Cupedidae. However, it is impossible to clarify subfamily attribution without re-examination of the type specimen.

- Stigmenamma heeri (Giebel, 1856) [Harpalus]; late Triassic, Rhaetian (formerly "Early Liassic"); England, Gloucestershire, Hasfiel.
Genus Synodus Hong, 1982 (Coleoptera), not Scopoli, 1777 (Alepisauriformes)

The type species of this genus is represented by the small and narrow elytron about $4 \mathrm{~mm}$ long and $1.5 \mathrm{~mm}$ wide described as a member of Cupedidae. The photographs of this elytron are not clear and the drawings show nine elongate convex stripes some of which look somewhat like primary veins becoming, however, not clear at apex and the sculpture between them apparently consisting of irregular elongate cells. To clarify family attribution a further re-examination of the type specimen is necessary, although the belonging of it to Archostemata remains very probable.

- Synodus changmaensis Hong, 1982; early Cretaceous, Aptian, Chijinpu Formation; China, Gansu Province, Yumen, Chenjiwan, Changma.

Genus Tentyridium Westwood, 1854

This genus was proposed for a species (Tentyridium peleus) represented by one lateral part and apex of elytron ( $7 \mathrm{~mm}$ long) which has the rather large and dense cells arranged in the long longitudinal rows and no trace of veins. Handlirsch (1906-1908) proposed another species name in this genus for another elytron $(8.5 \mathrm{~mm}$ long) illustrated by Westwood in the same publication which before remained without name (Westwood, 1894: pl. 16, Fig. 17). The latter elytron is rather different from that of Tentyridium peleus and probably belongs to a species from another genus. However the subfamily attribution of both is scarcely possible to define even after a re-examination of these specimens.

- Tentyridium peleus Westwood, 1854; early Cretaceous, Berriasian, Lulworth Formation; England, Dorset, Swanage/Purbeck.

- Tentyridium dilatatum Handlirsch, 1906; early Cretaceous, Berriasian, Lulworth Formation; England, Dorset, Swanage/Purbeck.

\section{Genus Tetrocupes Hong, 1983}

This genus was proposed for one elytron $12.0 \mathrm{~mm}$ long initially put in the family Cupedidae. It show four veins with 4-5 "rows of the pore" (?cells) between them. Besides, in the 
description four long parallel veins are mentioned, although the picture and drawing of this elytron show that probable $\mathrm{Cu}$ and $\mathrm{M}$ are running to be fused at apex. In order to clarify the subfamily attribution and position of this genus an additional re-examination of type specimens is needed.

- Tetrocupes cavernasus Hong, 1983; Middle Jurassic, Jiulongshan Formation; China, Hebei, Chengde, Xiaofanzhangzi.

\subsection{List of fossil cupedid species without generic attribution, incertae sedis (with in- definite positions)}

- “Liassocupes parvus" Hubert et al., 2003 (not Zeuner, 1962); early Jurassic, Towaco Formation; U.S.A., New Jersey, Roseland, Roseland Querry.

Hubert et al. (2003) identified an ellytron collected in USA as "Liassocupes parvus" described from U.K. and they also published a picture of it which looks like characteristic of cupedids with fused A1 and CuA and weakly raised primary veins. Nevertheless it is impossible to be sure in such identification and this specimens would be better to regard as a cupedid without subfamily and generic attribution.

- 'Priacma' corrupta Ponomarenko, 1986; early Cretaceous, early Neocomian; West Mongolia Hovd Ajmag, Myangad (Myangat).

The remains of its holotype represent the ventral sclerites of the pterothorax, and also the sclerites of legs and the basal parts of the hindwings. They share the characters of some cupedine genera, but, in contrast to Priacma serrata, the metaventrite of this species is transverse and its abdominal ventrite 1 is much longer than each of the ventrites $2-4$. The proposed original attribution of this fossil specimen to any subfamily also gives rise to doubt.

- 'Priacma' longicapitis Ponomarenko, 1997; early Cretaceous, ? early Aptian; Mongolia, Bayan-Khongor Aymag, Gobi-Altay, SharTologoy.

These remains correspond to the head (holotype) and to a separated elytron (additional specimen) somehow fitted to the holotype.
This taxon shares the characters of some cupedine genera with the slender and more or less subparallel-sided body showing the rather large cells on the elytra. The holotype has the head somewhat similar to that of Priacma serrata but without any characteristic feature that could provide an evidence for such attribution. The elytron seems to be similar to that of $P$. serrata and to species of some other cupedine genera with the narrow elytra wearing a weak primary venation. However, in contrast to members of Priacma and the similar genera, the mentioned elytron (additional specimen) has nine long longitudinal rows of cells. Therefore, the proposed original attribution of this fossil specimen to any subfamily also gives rise to doubt.

- 'Priacma' oculata Ponomarenko, 1997; early Cretaceous, ? Early Aptian; Mongolia, Bayan-Khongor Aymag, Gobi-Altay, Shar-Tologoy.

The remains of its holotype have the characters of Priacma as some other cupedine genera with narrow body (more or less similar head, part of thorax, elytron with slightly expressed primary veins and large cells), but there is no character that could increase the probability of its attribution to Priacma. Besides, the proposed original attribution of this fossil specimen to any subfamily is also problematical.

- 'Priacma' striata Ponomarenko, 2000; early Cretaceous, Argun' Formation; Transbaikalia, Chitiskaya Region, Elizavetinskaya depression, Semen.

The holotype is represented by the metathorax with elytra (with rather feeble primary veins) and abdomen (15 mm long). It differs from Priacma serrata by the long abdominal ventrite 1 and comparatively long hypopygidium. Ponomarenko (2000) mentioned that this species "has been allocated to the genus Priacma tentatively based on the long metathorax and the last abdominal sternite, and the elytra having characteristic colour pattern with longitudinal flecks". However, the proposed original attribution of this fossil specimen to a certain subfamily also gives rise to doubt. 


\section{Position of the genus Priacma LeConte, 1874}

Genus Priacma LeConte, 1874

Type species Cupes serratus LeConte, 1861, recent, by monotypy

History of studies. For a long time this genus was considered as perhaps the most interesting to study because it was regarded as an "archaic" member of the subfamily or family, even though more usually it was Omma and/or Tetraphalerus that were interpreted as more "primitive", "archaic" or "basal" for the "cupedine clade" (Atkins, 1958a, b, 1963; Hörnschemeyer, 2009; etc.). However, Priacma serrata had only been known from male adults until Ross and Pothecary (1970) obtained a female with eggs and even some freshly hatched $1^{\text {st }}$ instar larvae. Crowson (1962), albeit without a proper diagnosis, had proposed the tribe Priacmini to solely encompass the genus Priacma, but later a number of fossil genera were added to Priacmini as well (Ponomarenko, 1969, 1997; Tan, Ren, 2006, 2009; Tan et al., 2006; etc.). Hörnschemeyer (2009) proposed different phylogenetic hypotheses in which Priacma, together with the genus Paracupes, formed a separate clade in every case. Hünefeld et al. (2011) agree that Priacma and Paracupes represent a separate clade: "They likely represent the first two branches (or the first branch as a clade) within the family" (Hünefeld et al., 2011: 157). However, Kirejtshuk et al. (2010a) showed that taking into consideration also available fossils Priacma is distinct from the other cupedines only in structure of the male genitalia (but not in its external characters) and proposed to abandon this tribal taxon as inapplicable. In contrast, Bouchard et al. (2011) elevated its rank to the subfamily Priacminae, yet without any explanation or any note on its composition. Because only the male genitalia are a unique character of Priacma to distinguish the tribe or subfamily, only two members of this suprageneric taxon, Priacma and Gracilicupes, would be recognizable while many fossil genera with still unknown male genitalia are to be regarded as taxa of unclear positions. The authors of the present paper consider such taxonomic treatments as irrational and only confusing the classification, because most of the generic categories in the family Cupedidae still remain unassigned to a tribe or subfamily. Some paleocoleopterists have attributed a few fossils to the genus Priacma, but in all such cases this has been done without due evidence (see above "Notes on the taxonomy and systematics of the subfamily" and Chapter 8). Some of these forms are placed here in genera quite distinct from Priacma (see the genus Apriacma gen.n.).

Diagnosis. Body elongate of medium size $(9.5-16.5 \mathrm{~mm})$. Integument with moderately coarse sculpture and punctation; large subquadrangular(transverse) to polygonal cells of elytra arranged into 10 long longitudinal rows interspaced by weak secondary and more raised primary veins; A1 straight, almost reaching elytral apex and fusing with $\mathrm{CuA}$ before apex. Head usually subtriangular, with moderately narrow neck (about $3 / 4$ as wide as head at temples), with a pair of long paramedial convexities along eye edge to temples and covering base of antennal insertions and with very slightly expressed Y- or V-shaped depression, well projecting temples; antennal insertions moderately widely separated. Mandibles rather strong and arcuately curved at outer edge before stout bidentate apex. Mentum rather short and wide (more than twice as wide as long). Gular sutures widely separated, subgradually and slightly convergent posteriorly. Antennae submoniliform and moderately long; antennomere 1 (scape) subequal in length with flagellomere 3 and 2.53.0 times as long as antennomere 2 (pedicel) and more or less thicker; all flagellomeres subconical and progressively becoming shorter distad, although ultimamate and subultimate antennomeres subcylindrical and longer. Pronotum subtrapezoid, very slightly and rectilinearly widened anteriad, with subexplanate sides, projecting and subacute anterior angles, feebly tuberculate surface and weak median elevated stripe. Part of prosternum before procoxae markedly longer than procoxae. Elytra about three times as long as wide combined, with broadly arcuate lateral edges, subtruncate to subarcuate (or sub- 

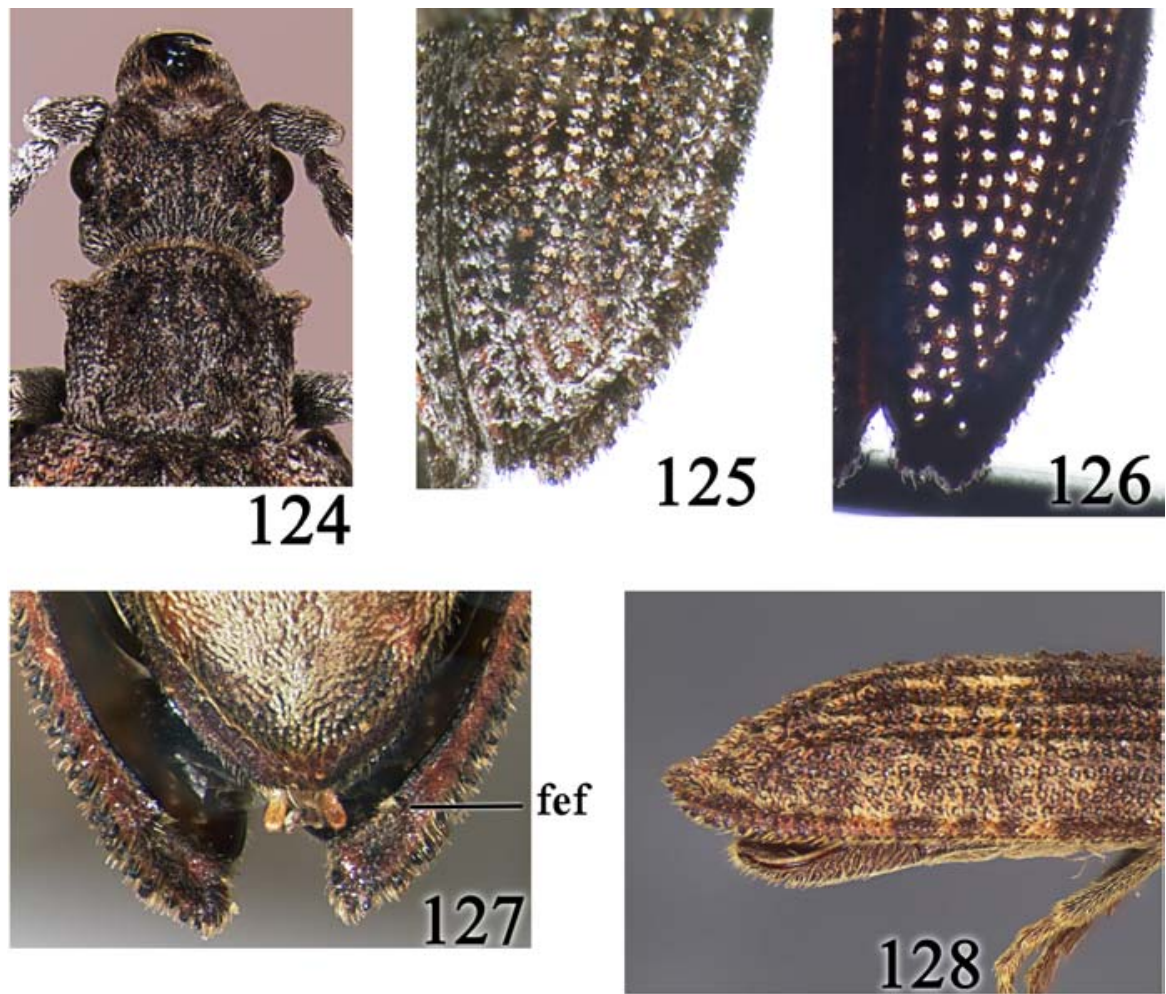

Figs 124-128. Priacma serrata LeConte, 1861 (ZIN “Montana, Hathead Co, Glacier Nat. Park, West Glacier, USA, 17 May 1993, Ivie"); recent; photographed under Leica MZ 12.0 with camera DFC290: 124 head and pronotum, dorsal; 125 - elytral apex, dorsal view under impinging light; 126 - idem, under transmitted light; 127 - elytral apices, ventral; 128 - posterior part of body, lateral. Length of body 16.4 $\mathrm{mm}$. Abbreviation: fef - fixing epipleural fold.

Pис. 124-128. Priacma serrata LeConte, 1861 (ZIN “Montana, Hathead Co, Glacier Nat. Park, West Glacier, USA, 17 May 1993, Ivie"); современный; сфотографированный на микроскопе Leica MZ 12.0 с камерой DFC290: 124 - голова и переднеспинка, сверху; 125 - вершина надкрылья, сверху при падающем свете; 126 - то же, при проходящем свете; 127 - вершины надкрылий, снизу; 128 задняя часть тела, сбоку. Длина тела 16,4 мм. Сокращение: fef - замыкающая эпиплевральная складка.

excised) apices and comparatively gently sloping sides, lateral edge thickened and with stripe bearing small, dense and sharp tubercles, epipleura with fixing fold. Metaventrite about as wide as long. Abdominal ventrite 1 somewhat shorter to subequal to each of ventrites 2-4 and hypopygidium markedly longest and rounded at apex. Legs moderately thin, moderately long; with protibia straight and tarsomeres 1-4 slightly narrower to subequally wide lobed. Aedeagus of Priacma-type, with rather long, subcylindrical and strongly curved parameres, volsellar plate, "digitus volsellaris", "cuspis volsellaris", penis ended with a laterally compressed dolabriform apex ("uncus").

On the structure of the male genitalia. Priacma is highly distinct among all modern beetles in an extraordinary structure of its male genitalia. Edwards (1953a, b) published very detailed studies of the genital capsule and aedeagus of Priacma serrata, emphasizing their considerable similarity to those in some Hymenoptera. Regrettably, the results of those important investigations remained almost fully 
ignored. Only Ponomarenko (1969) repeated the striking peculiarities which Edwards had observed in the male genitalia of Priacma serrata while Iablokoff-Khnzorian (1980), noting the Priacma-type aedeagus, questioned Edwards' interpretations of its structures. Lawrence (1999) wrote that "the aedeagus of all modern Archostemata (including Micromalthidae and Crowsoniellidae) is of a distinctive type described by Sharp \& Muir (1912) as having peculiarities which are "indications of an old relationship with Insects of another Order (perhaps something that preceded the existing Sialidae)". Later Martynov (1931) developed a hypothesis on the closer relation of Coleoptera and Megaloptera which became generally acknowledged (see below Discussion). However, after the Edwards' description of the male genitalia of Priacma the facts on the structure of the coleopteran male genitalia needed to be reconsidered. During some decades coleopterists did not pay attention on this situation. By the way, the structure of the coleopteran ovipositor can be considered as a possible "plesiomorphic form of the Neuropteroidian ovipositor" (Mickoleit, 1973: 38). Hörnschemeyer (2009) regarded that “clade XXVII (Priacma, Paracupes)", including "Paracupes" ascius (= Paracupoides subgen.n. here), was more basal to the other cupedines, treating them in a separate family, Cupedidae, but he did not pay attention to contradictions between the similarities in structure of the male genitalia and elytra. Eventually, the male genitalia in Priacma and Paracupes s.lato are very different (see Figs 129-134 and Vulcano \& Pereira, 1975: 51, Figs 27-35), but their elytra are even more strikingly different from those of Paracupoides subgen.n. (see above Chapter 6). Besides this, Hörnschemeyer (2009) found only three differences in structure of the male genitalia of Priacma and Paracupes s.lato: "dorsal plate" lying on the penis, "bifurcate process" between sternite 9 and the aedeagus, and the "position of the basal opening of the aedoaegus". However, even in the case of correctly coding all formalized characters of this organ (characters 58-84) in the matrix, of all 110 characters listed by that author, the resulting cladogram would look essentially different.
Many neontologists like Hörnschemeyer (2009) attach special importance to the "ventromarginal spines" and to the apical hooks of the parameres as characteristic features of the Archostemata, even though these are sometimes membranous, except for Priacma serrata, on the one hand, while also membranous rudiments of these structures are present in the parameres of certain groups of Polyphaga, on the other hand (e.g. very clear in the Recent members of Cerophytidae Latreille, 1834 - see Fig. 138139; illustrations in Costa et al., 2003: 381, Fig. 8; and particularly Costa et al., 2014: Figs 1119; etc.; Dascillidae Guérin-Méneville, 1843 see illustrations in Jin et al., 2013: 620, Fig. 18 P-R; Pleocomidae LeConte, 1861 - see illustrations in Lawrence et al., 2011: 136, Fig. 55 F; etc.). The species of Potergus Bonvouloir, 1871 (Throscidae Laporte, 1840) show articulated appendages located at base of parameres or places at joining parameres and phallobase (for example, Cobos, 1961: 2, Fig. 5).

The term "ventro-marginal spines" (Neboiss, 1984) for the processes along the parameres in archostematans, which is considered as a feature only characteristic of Archostemata as a whole (e.g. Hörnschemeyer, 2009), needs special comment as well, because the above interpretation leads to a serious confusion. Hörnschemeyer (2009) denoted the processes located along basal half of the parameres as "spines", but those located at the apices of the parameres as "hooks". Indeed, the aedeagus of Priacma has two pairs of short curved sclerites (each a "digitus volsellaris", or a "cuspis volsellaris") which, as in hymenopterans, are separated from both parameres ("lateral lobes") and penis trunk ("median lobe of aedeagus") and which are regarded as derivatives of gonocoxites 9 (Snodgrass, 1941). In other groups, these sclerites may have become fused to the base of the phallobase (one of the pairs) and parameres (another pair), this being observable in many groups of archostematans and polyphagans (mostly in elateriformians, particularly in the superfamily Byrrhoidea, very clearly in Chelonariidae, but in other groups with various degrees of expression: see members of Cneoglossa Guérin-Méneville, 1843 (Cneoglossidae 
Champion, 1897) in Costa et al., 1999: 270, Figs 45-48; numerous Eucnemidae Eschscholtz, 1829, with "secondary lateral lobes", in Muona, 1993: 94, Figs 111-114 etc.; some Eulichas Jacobson, 1913 (Eulichadidae Crowson, 1973), in Hajek, 2007: 15, Figs 31-32). Articulation between phallobase and parameres in the polyphagan aedeagus could be formed on base of a ring of volsellar plates and parameral plates in Priacma-type aedeagus.

The male genitalia of Priacma serrata are in need of further detailed investigations and comparisons with different groups of holometabolans and other orders [the male genitalia examined by the authors (Figs 129-134) look somewhat different from those illustrated by Edwards (1953a: 4-5, Figs 1-2; 1953b: 19, Fig. $1)$ ]. Its genital capsule is also different from that of other archostematans, and of the beetles in general which are known to have this structure. The ventral part of it in Priacma serrata (derivative of abdominal sternite 9) including a pair of sclerites gradually widening posteriad and fused together by their proximal ends (somewhat similar to those in Paracupes: Vulcano, Pereira, 1975: 51, Fig. 35) while the dorsal part (derivative of abdominal tergite IX) with two sharp paramedian pairs of narrow acuminate processes at the apex which are oriented mesally is extremely distinct. Nevertheless, this segment is more similar to that in the other beetles rather than in hymenopterans and its peculiarities are usually regarded as an apomorphy of the order Coleoptera (Hünefeld et al., 2011). In contrast, the aedeagus of Priacma serrata is more similar to that in the hymenopterans (Boulange, 1924; Snodgrass, 1941) rather than in the other beetles and even in other orders of Neuropterida (Aspöck, 2000), although Sharp and Muir (1912) had found some "indications" of a relation of male genitalia in Coleoptera (but not Priacma ones) to those in Megaloptera (Sialidae). However the similarity of Priacma and hymenopterans concerns the volsellar plate, "digitus volsellaris", or "cuspis volsellaris", which are characteristic of many hymenopteran groups (Kimsey, Wasbauer, 2013; Pesenko, 1983; Smith, Shinohara, 2011; etc.) which could, in turn, be homologous with basal appendages of both parameres and penis trunk. As in hymenopterans each "cuspis voscellaris" of the Priacma male aedeagus has a strong muscle provides producing an approaching of digiti and cuspes each other to, when the muscles of both cuspes are contracted (Edwards, 1953b). However, the aedeagus of Priacma serrata also shares certain similarities to those of elateriformians (see above) which, in contrast to the aedeagus of archostematans, show some conformations reminiscent of the volsellar structures of hymenopterans. At the same time, in addition to the notes of Edwards (1953a) on the similarity of the male genitalia of P. serrata to those of Hymenoptera, there are some similarities to those of the other Holometabola. The "uncus" of the penis trunk of $P$. serrata is more similar to that in certain groups of Lepidoptera (e.g. some Sphingidae Latreille, 1802: see in Simonsen \& Kitching, 2014) rather than to the probable homologue in some Coleoptera (as in the cupedine Rhipsideigma: see Neboiss (1984: 466, Figs 59-66), as well as in the elateriformians. S.Yu. Sinev considers that the structure denoted as "uncus" could have had independent origins in different lepidopteran groups and frequently its shape is functionally conditioned (personal communication). Some similarities are also traced in the male genital structures of Priacma and some dipterans (e.g. Sinclair, 2000). However, probable homologizations of structural details need a more careful study. For instance, the parameres in the flies seem to be in the same position as the cuspis volsellaris of Priacma while the parameres in Priacma seem to be in the same position as the gonostyli of the flies (cf. Fig. 129 to Sinclair, 2000: fig. 2.1).

On some external structures. The genus under consideration is also characterized by the distinct subtruncate elytral apices, as well as by the particular rows of sharp teeth along the lateral elytral edge and the "fixing" epipleural fold in Priacma serrata (Fig. 127). In most cupedines, however, the elytral apices are conjointly subacute, forming a joint angle, but fossil representatives of Anaglyphites stat.n., $\mathrm{Cu}$ pidium, Kirghizocupes, and Priacma, as well as the modern species of Paracupes s.str. and 

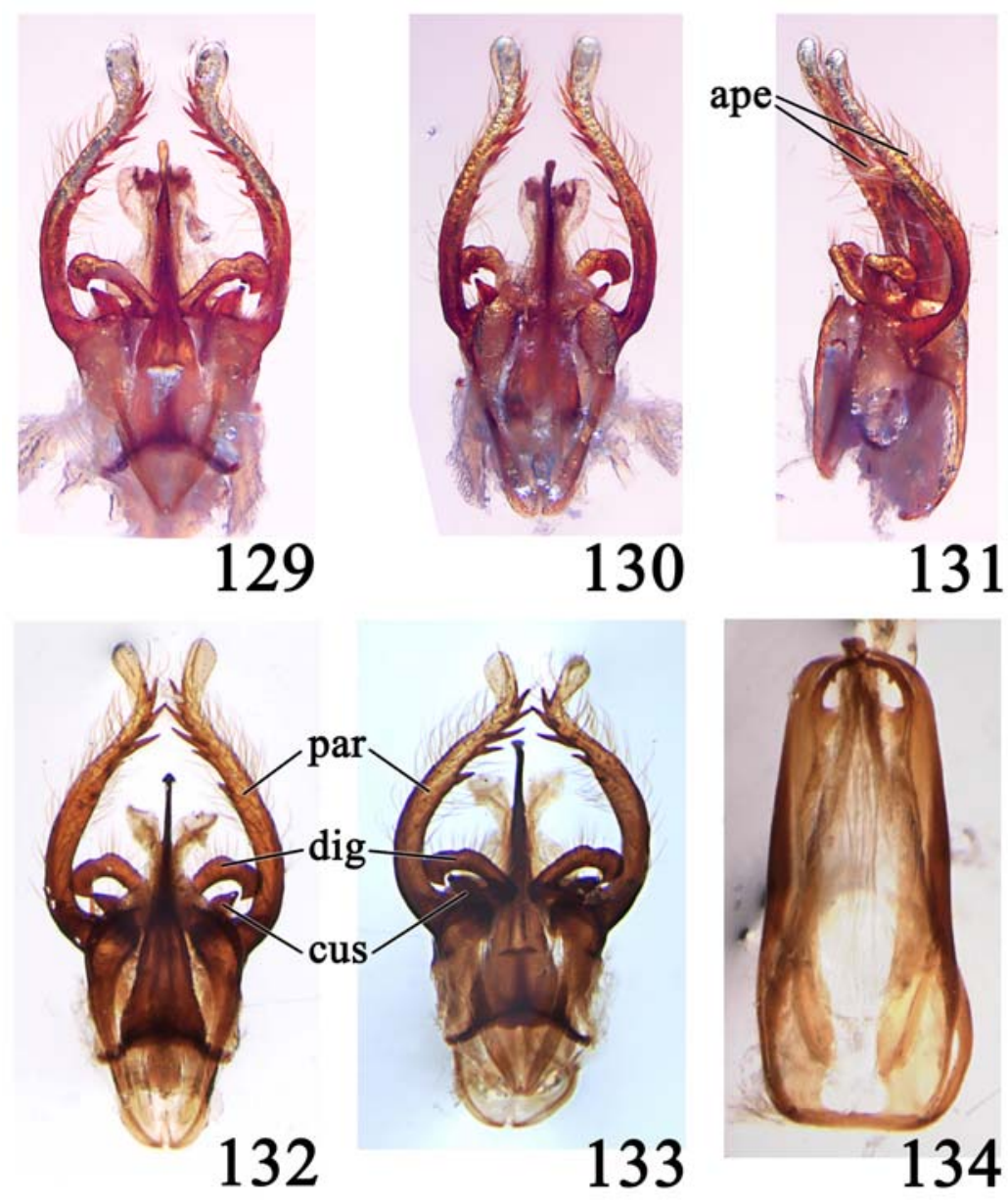

Figs 129-134. Male genitalia of recent Priacma serrata LeConte, 1861 (ZIN "Montana, Hathead Co, Glacier Nat. Park, West Glacier, USA, 17 May 1993, Ivie"): 129 — aedeagus extracted from body without preparation, dorsal, photographed under Olympus SCX9 with camera Olympus, length $1.7 \mathrm{~mm} ; 130$ idem, ventral; 131 - idem, lateral; 132 - aedeagus after maceration by $\mathrm{KOH}$, dorsal, photographed under Leica MZ 12.0 with camera DFC290; 133 - idem, ventral; 134 - male genital capsule without ventral "bifurcate process" ("abdominal segment IX"), dorsal, length $2.0 \mathrm{~mm}$. Abbreviations: ape — apex of penis trunk ("uncus"), cus — “cuspis volsellaris", dig — "digitus volsellaris", par - parameres.

Рис. 129-134. Гениталии самца современного Priacma serrata LeConte, 1861 (ZIN "Montana, Hathead Co, Glacier Nat. Park, West Glacier, USA, 17 May 1993, Ivie"): 129 - эдеагус, извлеченный из тела, без обработки, сверху, сфотографированный на микроскопе Olympus SCX9 с камерой Olympus, длина 1,7 мм; 130 - то же, снизу; 131 - то же, сбоку; 132 - эдеагус после обработки в едкой щелочи $(\mathrm{KOH})$, сверху, сфотографированный на микроскопе Leica MZ 12.0 с камерой DFC290; 133 — то же, снизу; 134 - генитальная капсула самца без нижних выростов "bifurcate process" (“брюшного сегмента IX"), сверху, длина 2,0 мм. Сокращения: аре - вершина ствола пениса (“uncus"), cus "cuspis volsellaris", dig — "digitus volsellaris", par - парамеры.

Paracupoides subgen.n., demonstrate the elytral apices separately rounded or truncate (Figs $84,87,125,126)$. Observing this character in fossils is associated with some potential obsta- cles because of possible deformations of the elytral apices specified by the positions of the remains during, and by the circumstances of fossilization. The important characters give the 


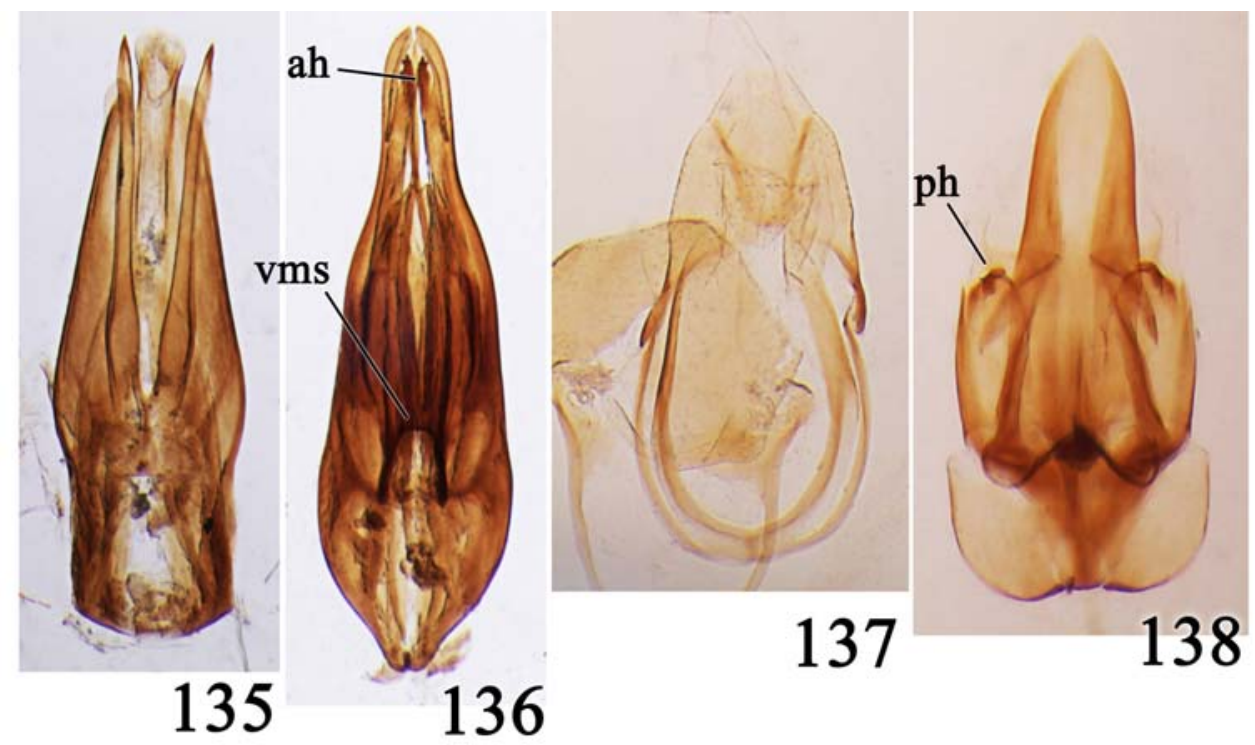

Figs 135-138. Male genitalia of recent representatives of Cupedidae and Cerophytidae, photographed under Leica MZ 12.0 with camera DFC290: 135 - male genital capsule ("abdominal segment IX") of specimen of Cupes mucidus Chevrolat, 1829 (ZIN “Okr. Chernigovki, Prim. obl., Emel'yanov, 3 VII 914 " (in Cyrillics)), ventral; 136 - aedeagus of this specimen, ventral; 137 - male genital capsule ("abdominal segment IX") of specimen of Cerophytum japonicum Sasaji, 1999 (ZIN "Vinogradovka, Ussur. kr., 1.vi.929, D'yakonov Philip" (in Cyrillics)), ventral; 138 - aedeagus of this specimen, ventral. Abbreviations: ah apical hook of parameres, $\mathrm{ph}$ - parameran hook, vms - ventro-marginal spine of base of parameres.

Рис. 135-138. Гениталии самцов современных представителей Cupedidae и Cerophytidae, сфотографированные на микроскопе Leica MZ 12.0 с камерой DFC290: 135 — генитальная капсула (“брюшной сегмент IX”) экземпляра Cupes mucidus Chevrolat, 1829 (ZIN “Окр. Черниговки, Прим. обл., Емельянов, 3 VII 914 ”), снизу; 136 - эдеагус этого же экземпляра, снизу; 137 - генитальная капсула (“брюшной сегмент IX”) экземпляра Cerophytum japonicum Sasaji, 1999 (ZIN “Виноградовка, Уссур. кр., 1.vi.929, Дьяконов Филип”), снизу; 138 - эдеагус этого экземпляра, снизу. Сокращения: ah вершинный крючок парамеры, $\mathrm{ph}$ - крюк парамеры, vms - вентромаргинальный отросток основания парамеры.

elytral sides sometimes bearing the longitudinal stripe with sharp and dense tubercles (teeth or crenulation at adge) along epipleuran carina are well expressed in Priacma, Paracupes s.str. (Figs 125-128, 155, 157), while in Paracupoides subgen.n., there are only traces of such stripes (Fig. 156) and other recent cupedines such stripes are completely reduced (Figs 71, 72, 158). Unfortunately, these characters of Priacma remain without an adequate comparison among the members of Cupedinae, because it is scarcely traceable among fossils. Nevertheless, the holotype of Mesocupes (Anaglyphites) admotus certainly has serrate edges of the elytra showing teeth arranged in two parallel rows (as in Priacma and Paracupes s.str.). At the same time, this might not have been a random coincidence between the type of sloping of the elytral sides and the development of rows of teeth along the lateral sides, even though it is difficult to suggest any functional or evident morphogenetic link between these characters. The fixing epipleural fold (Fig. 127) at the elytral apices is unique among the modern cupedids, but likewise it seems to be almost impossible to trace this feature in fossils. The first idea for the usage of this structure that comes to mind is to promote a reliable fixation of the abdomen. The cu- 
pedines have a rather strong fixation of the abdomen and elytra due to the subvertical laterosternites and steeply sloped elytral sides forming tightly congruent surfaces of these organs. The fixing epipleural folds could serve as an additional mechanism providing a more reliable fixation of abdomen and elytra. If so, their presence in Priacma could provisionally be interpreted as an adaptation to living in (semi) aquatic or other very wet conditions, by analogy with the structures along elytral sides considered by Crowson(1981), Kirejtshuk et al.(2013) and others.

The long paramedian convexities on the head of Priacma serrata (at least in a certain position in respect of the light) show an impression of the "Y-depression" (Fig. 124) while such a formation is not so well expressed in other modern cupedines. Instead it is somewhat similar to those in many Mesozoic cupedids. In some cases it grants a good diagnostic character (see above "Key to genera and subgenera"), but its phylogenetic interpretation is frequently rather restricted because of various reasons, including its bad preservation in some fossils.

The comparatively short abdominal ventrite 1 of Priacma serrata is similar to that in representatives of Kirghizocupes, although these genera demonstrate enough of other clear characters to be easily distinguished (see below). At the same time, this similarity can be combined with some similarity in the elytral apices of both groups which are clearly not conjointly subacute, but rather separately rounded or subtruncate (see Figs 109-116 and 125). Nevertheless, Priacma and Kirghizocupes seem to be hardly closely related groups among cupedines because, in contrast to Priacma serrata, members of Kirghizocupes have the elytra with very weak veins which are not fused at the elytral apices. Finding a specimen of Kirghizocupes with exposed male genitalia would be essential to clarify the relationship between these groups.

Comparison. This genus has the Priacmatype male aedeagus similar to that in Gracilicupes but differs from the latter in the longer prosternum before the procoxae, the somewhat longer the head with smaller eyes, the convexities covering antennal insertions, the much wider and subquadrangular pronotum (wider than head), the thicker antennae with the longer and thicker scape and very short antennomere 2 , the shorter abdominal ventrite 1 . Taking into consideration the expression of raised elytral $\mathrm{M}$ and isolation of lateral elytral stripes in the species of Gracilicupes, the steepness of the slopes of elytral sides in the latter is markedly greater than that in Priacma. Also, in contrast to Priacma, the elytral lateral edges of Gracilicupes are simple and have no trace of serrate stripes.

Priacma, in addition to the distinct male genitalia, differs from other cupedine genera with 10 long longitudinal rows of cells on elytra in the following characters:

- Anaglyphites stat.n. in the more slender body, the clear convexities on the frons covering base of the antennal insertions, the pronotum with the rectilinear sides and strongly projecting anterior angles, the much narrower and longer elytra with the clear primary veins and fusion of $\mathrm{A} 1$ and $\mathrm{CuA}$, the shorter abdomimal ventrite 1 ;

- Cainomerga subgen.n. in the not so slender body with more rectilinear elytral sides, the more covered antennal insertions, the somewhat shorter and thicker legs and the much shorter abdominal ventrite 1 ;

- Chalepocarabus in the more slender body with elytral sides not arcuate, the shorter and transverse pronotum with the rectilinear sides and projecting anterior angles, the raised primary veins, the longer and thicker scape and very short antennomere 2, the shorter abdominal ventrite 1 ;

- Kirghizocupes in the shorter (not elongate) head, the clear convexities on the frons covering the base of antennal insertions, the narrower prothoracic segment with the narrowly subexplanate pronotal sides and the somewhat less quadrangular cells on elytra;

- Menatops gen.n. in the much longer head with smaller eyes, the clear convexities on the frons covering the base of antennal insertions, the narrower and longer elytra, and the shorter abdomimal ventrite 1 ; 
- Mesocupes s.str. in the more marked primary veins, the clear convexities on the frons covering the base of antennal insertions, the thicker antennae with the longer and thicker scape and very short antennomere 2, the shorter abdominal ventrite 1 ;

- Paracupes sensu str. in the frons with two pair of tubercles, the widely separated gular sutures, the longer ventrite 1 and the not curved protibiae;

- Paracupoides subgen.n. in the frons with two pair of tubercles, the elytra with the less expressed primary veins, the gently sloping sides and the serrate lateral edge, the widely separated gular sutures, the longer ventrite 1 and the not curved protibiae.

In addition to another type of aedeagus, Priacma differs from modern cupedine genera after the keys proposed by Atkins (1948) and Crowson (1962) and from the fossil genera with nine long longitudinal rows of cells on the elytra in the number of these rows of cells and also in the following characters:

- Apriacma gen.n. in the absence of Yshaped depression behind the antennal insertions, the subtruncate elytral apices, the shorter abdominal ventrite 1 ;

- Cretomerga gen.n. in the absence of Yshaped depression behind the antennal insertions, the wider neck behind temples, the longer prosternum and the narrowly separated procoxae;

- Cupes in the gently sloping elytral sides, the subtruncate elytra apices, the absence of tarsal gooves on prosternum;

- Cupopsis gen.n. in the head with the small eyes and not concave along the anterior part of their edges;

- Furcicupes in the subtruncate elytral apices, the absence of Y-shaped depression behind the antennal insertions and the wider neck behind temples;

- Latocupes (? = Pulchicupes) in the more slender body, the longer pronotum, the not transverse cells on the elytral disk, and the absence of Y-shaped depression on the frons;

- Miocupes in the more slender body, the narrow and not transverse head with the not strongly projecting temples, the longer pronotum, the shorter prosternum before the procoxae, and also in the not parallel primary veins and more distinct cells on the disk of elytra;

- Taxopsis gen.n. in the smaller body-size, the not transverse cells on the elytral disk, the narrow prosternal process.

Finally, Priacma differs from the genera with unclear number of long longitudinal rows of cells, namely from Priacmopsis in the smaller and much more slender body, and the shorter prosternum before the procoxae, and from $\mathrm{Cu}$ pidium in the markedly more slender body, the shorter antennomere 2, the longer pronotum with the rectilinear sides and the projecting anterior angles, the truncate (but not separately rounded or conjointly subacute) elytral apices.

Note. If the male genitalia of Priacma are similar to those of Gracilicupes, other external characters of Priacma seem to share more similarities with those of Furcicupes (see above).

On a phylogenetic interpretation. The traditional interpretation of a relationship of Priacma and other cupedines as admitted by Edwards (1953a, b), Atkins (1958a) and many later authors cited in the below list of reference is supported by new data analyzed in the present paper. The numerous plesiomorphic characters observed in structure of the male genitalia can be seen as the trace of a very old split between cupedines, and also ommatines and probably polyphagan beetles. An independent structural instauration of "ancestral" structure of the male genitalia in both Priacma and Gracilicupes (as changes in the sequence of a normal ontogenetic development as described by Tichomirova (1981) in the genital structures of some staphylinids) can scarcely be admitted. Therefore, the attribution of Priacma together with Gracilicupes to a very old lineage (clade) of Coleoptera can be a more reasonable assumption expressed in a joint structure of the male genitalia that may have been formed at the very early stage of diversification of the order, when some its subgroups maintained the comparatively plesiotypic male genitalia while others could have already had a derived (apotypic) structure of this organ which might have given rise at least to 

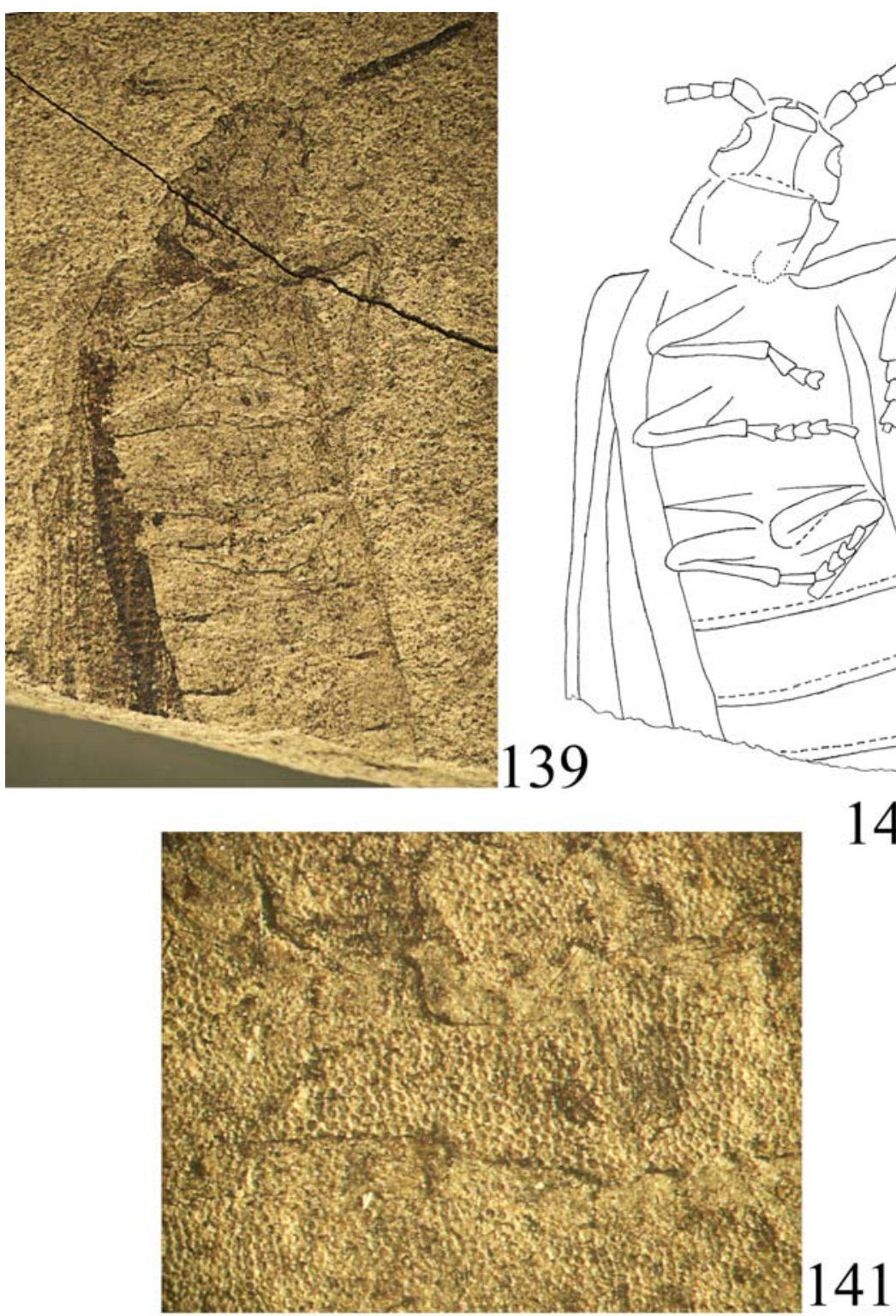

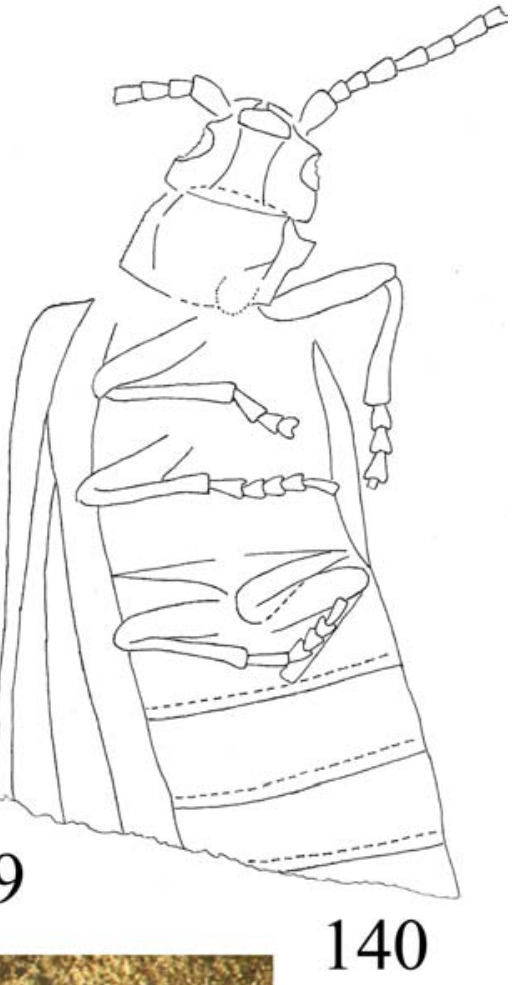

141

Figs 139-141. Mesocupes (Cainomerga) fraternus sp.n. (holotype "MNHN.F.A52773"); Paleogene, Paleocene; France, Menat: 139 — dry print, photographed under Olympus SCX9 with camera Olympus; 140 — body, ventral, with broken line outlined anterior edge of pronotum; 141 — integument of pterothorax. Length of specimen without apical parts of abdomen and elytra $14.6 \mathrm{~mm}$.

Рис. 139-141. Mesocupes (Cainomerga) fraternus sp.n. (голотип “MNHN.F.A52773”); палеоген, палеоцен; Франция, Мена: 139 - сухой отпечаток, сфотографированный на микроскопе Olympus SCX9 c камерой Olympus; 140 - тело, снизу, прерывистой линией очерчен передний край переднеспинки; 141 - поверхность птероторакса. Длина экземпляра без вершинных частей брюшка и надкрылий 14,6 мM. 

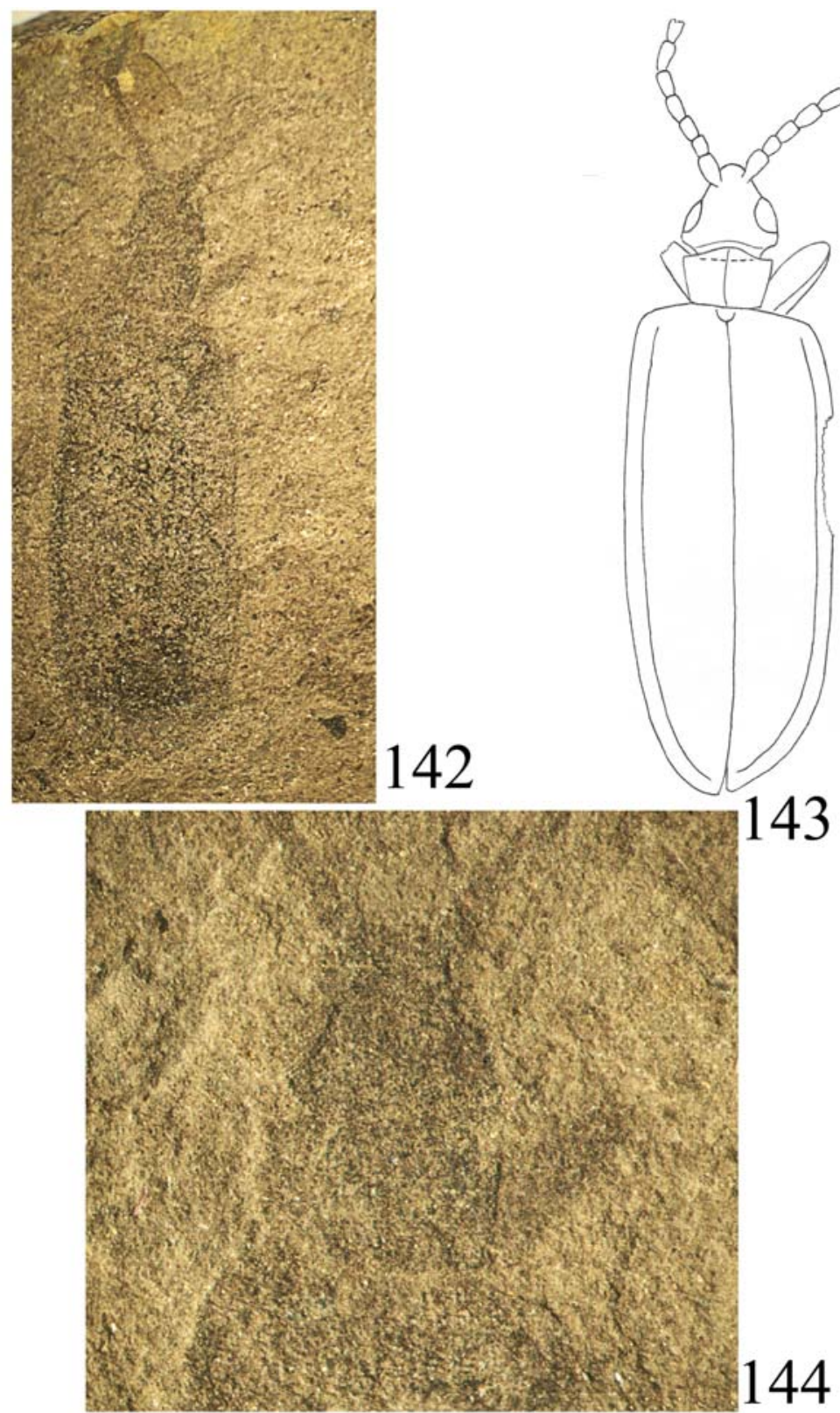

Figs 142-144. Genus incertus sp.1 (MNHN "R 63906”) (subfamily Cupedinae); Paleogene, Paleocene; France, Menat: 142 - dry print, photographed under Olympus SCX9 with camera Olympus; 143 — body, dorsal, with broken line outlined anterior edge of prosternum; 144 - integument of anterior part of body. Length of specimen $12.6 \mathrm{~mm}$.

Рис. 142-144. Genus incertus sp.1 (MNHN "R 63906”) (подсем. Cupedinae); палеоген, палеоцен; Франция, Мена: 142 - сухой отпечаток, сфотографированный на микроскопе Olympus SCX9 c камерой Olympus; 143 - тело, сверху, прерывистой линией очерчен передний край переднегруди; 144 - поверность передней части тела. Длина экземпляра 12,6 мм. 

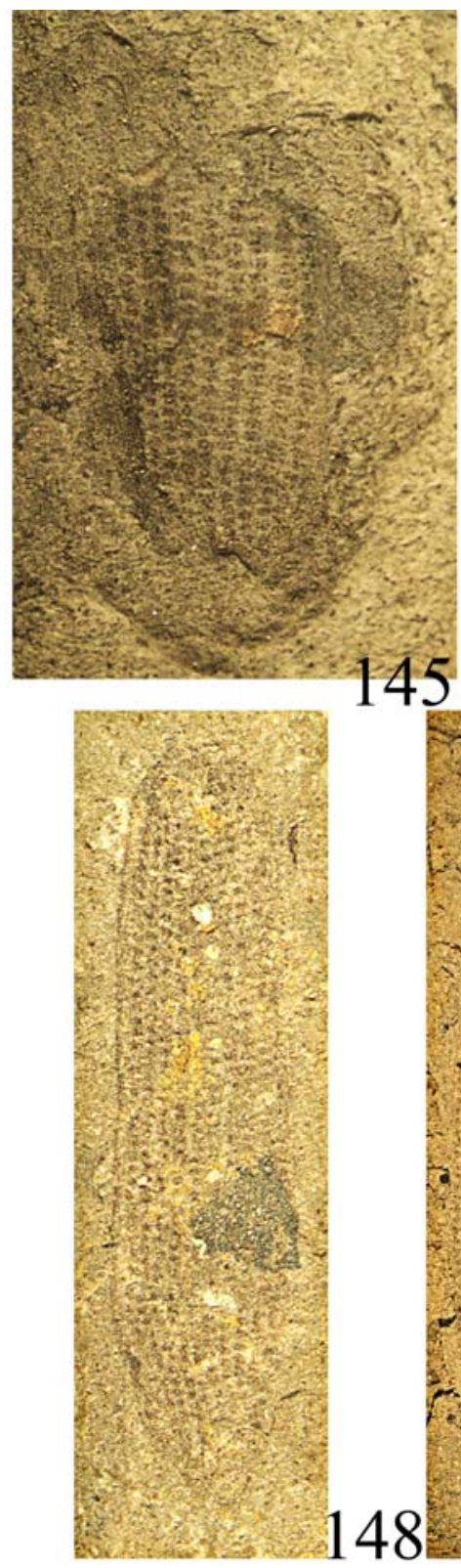
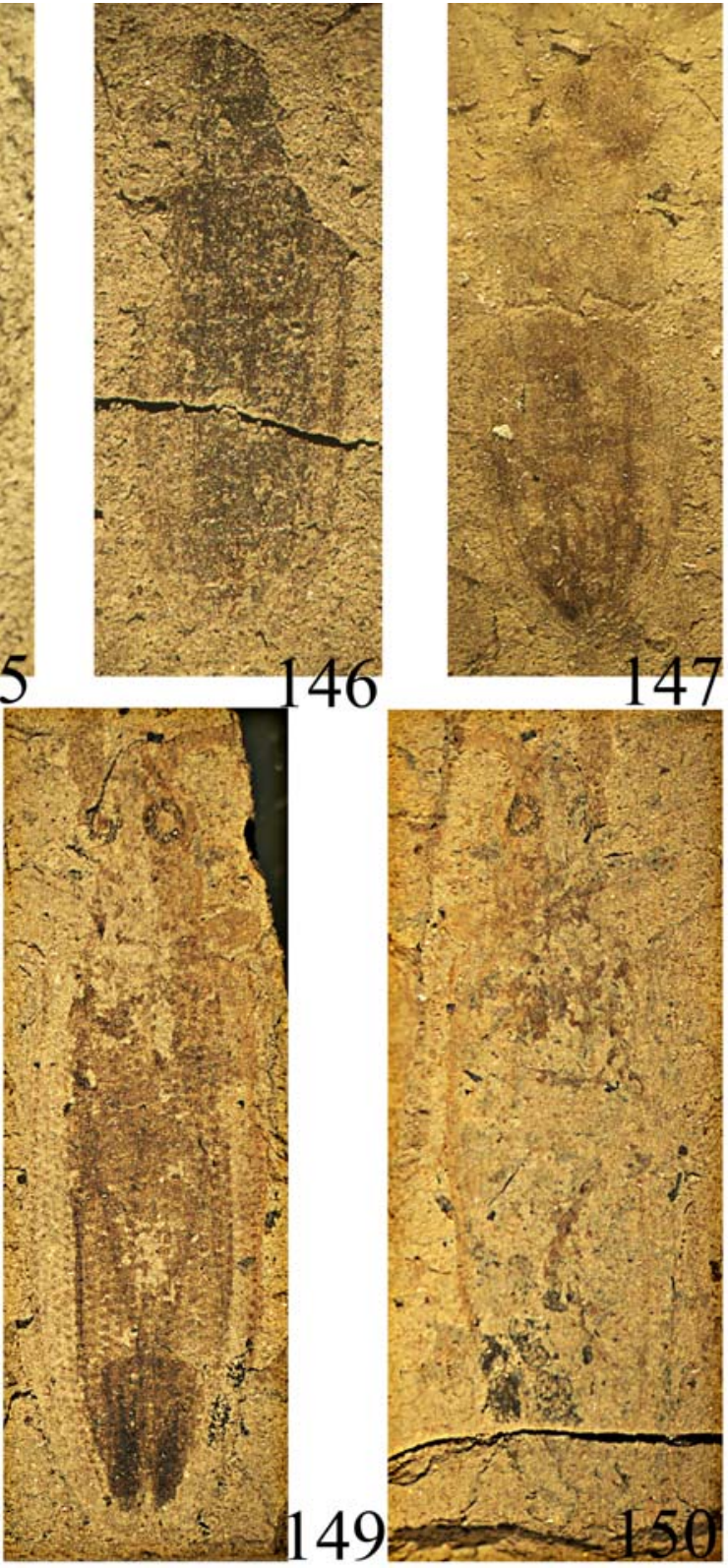

Figs 145-150. Fossil species of the subfamily Cupedinae, photographed under Olympus SCX9 with camera Olympus; Paleogene, Paleocene; France, Menat: 145 - apex of elytron of(?) Mesocupes (Cainomerga) sp.1 ("MNHN.F.A.52768"), dry print, length of apex of elytron $7.0 \mathrm{~mm} ; 146$ - Cupes aff. manifestus ("MNHN.F.A.52771"), dry print, length of body $5.6 \mathrm{~mm}$; 147 — Cupes aff. manifestus ("MNHN.F.A.52770"), dry print, length of body $7.8 \mathrm{~mm}$; 148 - Mesocupes (Cainomerga) sp., "MNHN.F.A.52769", dry print, length of elytron $12.6 \mathrm{~mm} ; 149$ - Genus incertus sp. 2, "MNHN.F.A.52794", dry print, length of body 14.4 $\mathrm{mm} ; 150$ - idem, dry counterprint.

Рис. 145-150. Ископаемые виды подсем. Сupedinae, сфотографированные на микроскопе Olympus SCX9 с камерой Olympus; палеоген, палеоцен; Франция, Мена: 145 - вершина надкрылья (?) 

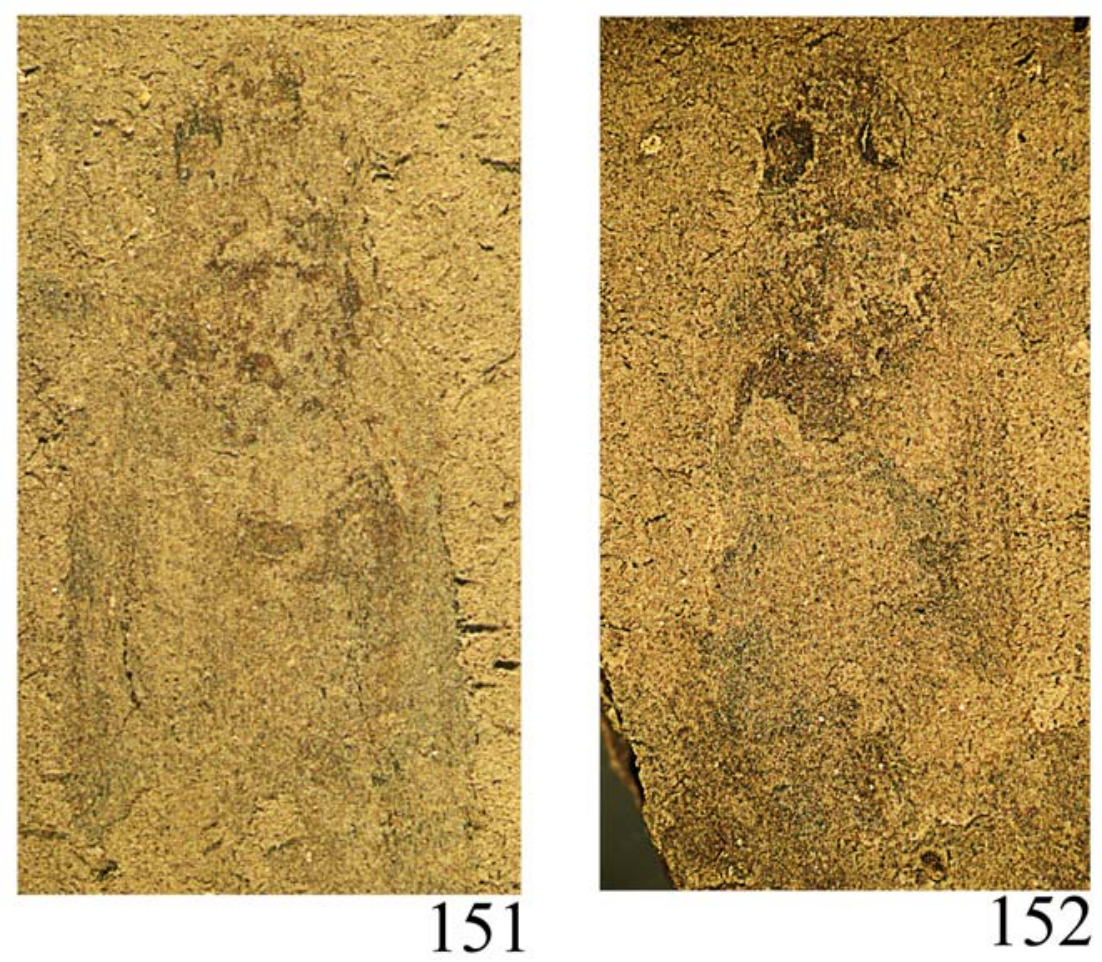

Figs 151-152. Genus incertus sp.3 (“MNHN.F.A.52772") (subfamily Cupedinae), photographed under Olympus SCX9 with camera Olympus; Paleogene, Paleocene; France, Menat: 151 - anterior part of dry print, length of body $13.2 \mathrm{~mm}$; 152 - anterior part of dry counterprint.

Рис. 151-152. Genus incertus sp.3 (“MNHN.F.A.52772”) (подсем. Cupedinae), сфотографированный на микроскопе Olympus SCX9 с камерой Olympus; палеоген, палеоцен; Франция, Мена: 151 — передняя часть сухого отпечатка, длина тела 13,2 мм; 152 - передняя часть сухого противоотпечатка.

Cupedinae, Ommatinae, Micromalthidae, Crowsoniellidae, and Polyphaga, if not to all other modern groups of this order. If so, 10 long longitudinal rows of cells on the elytra of Priacma and Gracilicupes could also represent an initial state of the character to that with less number of rows of cells. Both types of sloping of the elytral sides apparently associated with the serration of the elytral edges and the tuberculation of the frons could have been homoplastic in the phylogeny of cupedines. The recurrence of the different conditions of these structures during the historical development of the subfamily Cupedinae might have been related to some morphocyclic evolutionary processes (Emel'yanov, 2000) providing the parallel similar changes in different structures and causing a regular convergence (see "Discussion" below). An example of such a recurrence in elytral structure is shown here in the pair Paracupes s.str. - Paracupoides subgen.n. Priacma together with Gracilicupes having the "archaic"

Mesocupes (Cainomerga) sp.1 (“MNHN.F.A.52768”), сухой отпечаток, длина вершины надкрылья 7,0 мм; 146 - Cupes aff. manifestus (“MNHN.F.A.52771”), сухой отпечаток, длина тела 5,6 мм; 147 Cupes aff. manifestus ("MNHN.F.A.52770"), сухой отпечаток, длина тела 7,8 мм; 148 - Mesocupes (Cainomerga) sp., "MNHN.F.A.52769”, сухой отпечаток, длина надкрылья 12,6 мм; 149 - Genus incertus sp.2, "MNHN.F.A.52794", сухой отпечаток, длина тела 14,4 мм; 150 - то же, сухой противоотпечаток. 

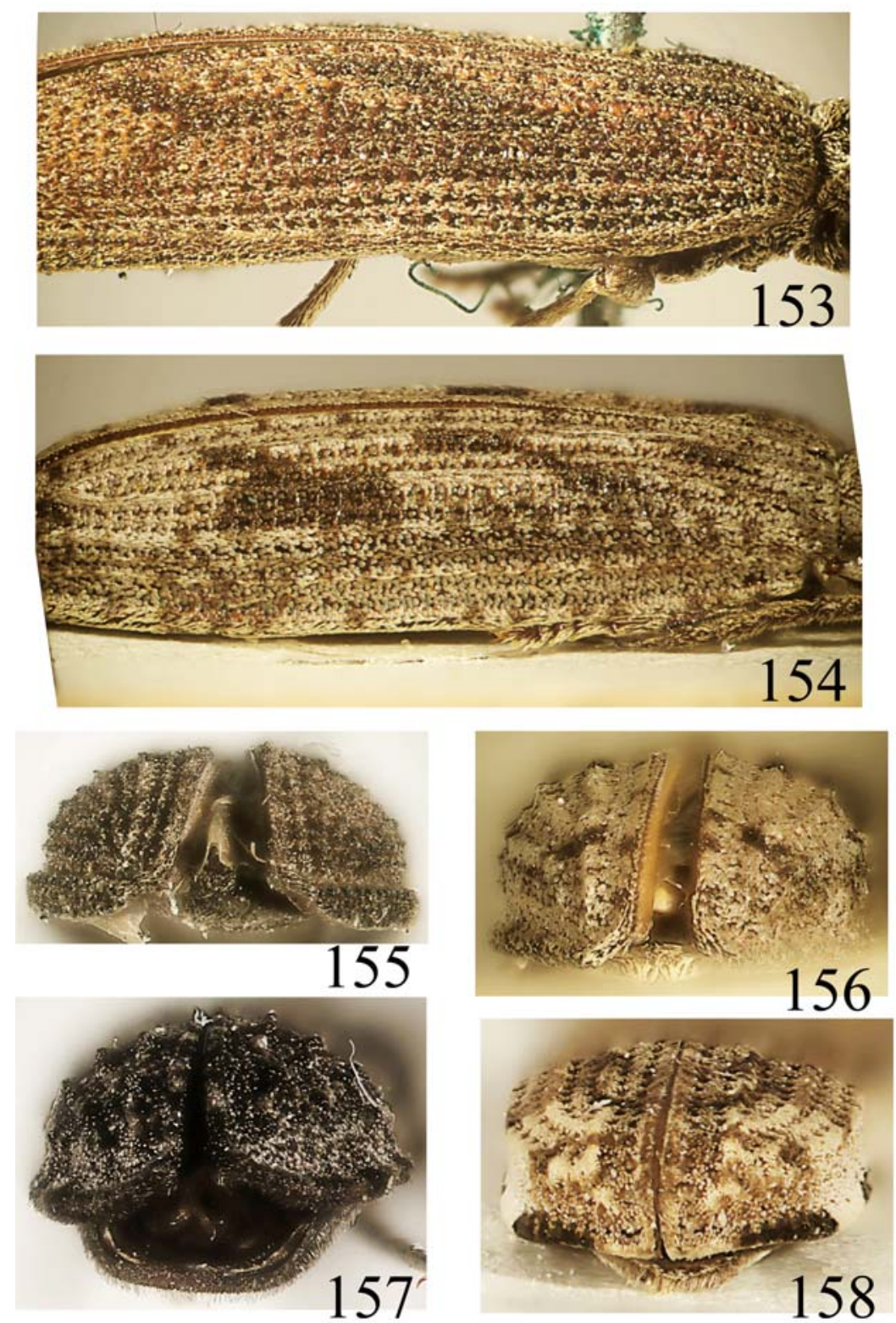

Figs 153-158. Recent species of the subfamily Cupedinae, photographed under Olympus SCX9 with camera Olympus: 153 - Paracupes (Paracupes) brasiliensis Kolbe, 1908 (MNHN, "Brasil, (?) Mur" "ex Museo Mniczech" "coll. R. Oberthur"), elytron, lateral; length of body $16 \mathrm{~mm} ; 154-P$. (Paracupoides) ascius Neboiss, 1989, holotype (MNHN, "Equateur Or., de Bacos a Canelos, M. de Mathan, IX-X.1894"), elytron, lateral; length of body $10.4 \mathrm{~mm} ; 155-P$. (Paracupes) brasiliensis (same specimen - see above), elytra, posterior; width $4.9 \mathrm{~mm} ; 156-P$. (Paracupoides) ascius (same specimen - see above), elytra, posterior; width 2.9 mm; 157 - Priacma serrata LeConte, 1861 (ZIN "Montana, Hathead Co, Glacier Nat. Park, West Glacier, USA, 17 May 1993, Ivie"), elytra, posterior; width $4.5 \mathrm{~mm} ; 158$ - Adinolepis (Ascioplaga) mimeta (Neboiss, 1984), comb.n., holotype, male (MNHN, "Mt Koghi, 15.iii. 1978 (Delobel)"), elytra, posterior; width $2.6 \mathrm{~mm}$. 
aedeagus type could thus be suggested to be the sister to Permocupes unless to any tschekardocoleid group (see "Discussion" below).

\section{Taxonomic rank of Adinolepis Neboiss, 1984 and Ascioplaga Neboiss, 1984}

Neboiss (1984) initially proposed both $\mathrm{Ad}$ inolepis and Ascioplaga as two separate genera, the former is endemic to Australia and the latter to New Caledonia. The main difference of them consists in the character of distribution of scales on the elytra and some features in the structure of male genitalia (Neboiss, 1984: 459: "different elytra vestitute and male genitalia characteristics"). Both groups under consideration have a clear current isolation in space. In contrast to the synonyms between Cupes, Tenomerga, and Distocupes, the pair Adinolepis and Ascioplaga seems to be somehow analogous to the pair Paracupes s.str. and Paracupoides subgen.n., although the latter pair of two taxa is certainly more distinguishable than the former pair. To get somehow a balanced classification with comparable hiati between taxa of the same rank is the reason to lower the rank of Ascioplaga stat.n. and consider it in the genus Adinolepis s.lato.

\section{Discussion}

Historical overview of studies on Archostemata

The Archostemata, Cupedidae and Micromalthidae have been placed in the Polyphaga by most of the earliest authors. Ganglbauer (1903) assigned the Cupedidae in the Adephaga and
Lameere (1903) proposed the Cupediformia as the most "primitive" group of the Adephaga. Kolbe (1908) coined the name Archostemata and included that group in his division Symphytogastra of the suborder Heterophaga. Sharp \& Muir (1912) placed the Cupedidae in the Byrrhoidea (currently the infraorder Elateriformia) on the basis that the male genital tube of Cupes is of the "trilobe" type (herein, the Cupes-type), the most "generalised" ("primitive") existing in the living Coleoptera. Finally, Forbes (1926) erected the suborder Archostemata (including Cupedidae and Micromalthidae) to separate them from the Adephaga, based on the difference in the spiral rolling of the forewing apex. Böving and Craighead (1930) recognised the subordinal level, considering, however, that the larval structures allowed for archostematans to be regarded as representatives of a distinct ancient group. Since that time the Archostemata is considered as the oldest group in the order, but its relationships with the other suborders are still under discussion. Crowson (1981) tried to divide the Archostemata into three suborders, adding the usage of the Protocoleoptera Tillyard, 1924 and Archecoleoptera Crowson, 1981. However, the name Protocoleoptera had been proposed only for the family Protocoleidae (Tillyard, 1924), which is now considered a component of the order Protelytroptera (Forbes, 1928; Carpenter, 1992; etc.). The Archecoleoptera was introduced by Crowson for the Permian beetle groups except Tshekardocoleidae, but the usage of this name is scarcely warranted because it is probably a paraphyletic group and includes the late Permian taxa only sharing some structural similarities which could appear as convergence from an Early Permian

Рис. 153-158. Современные виды подсем. Сupedinae, сфотографированные на микроскопе Olympus SCX9 с камерой Olympus: 153 - Paracupes (Paracupes) brasiliensis Kolbe, 1908 (MNHN, "Brasil, (?) Mur" "ex Museo Mniczech" “coll. R. Oberthur"), надкрылье, сбоку; длина тела 16 мм; $154-P$. (Paracupoides) ascius Neboiss, 1989, голотип (MNHN, "Equateur Or., de Bacos a Canelos, M. de Mathan, IX-X.1894"), надкрылье, сбоку; длина тела 10,4 мм; 155 - P. (Paracupes) brasiliensis (тот же экземпляр, см. выше), надкрылья, сзади; ширина 4,9 мм; 156 - P. (Paracupoides) ascius (тот же экземпляр, см. выше), надкрылья, сзади; ширина 2,9 мм; 157 - Priacma serrata LeConte, 1861 (ZIN "Montana, Hathead Co, Glacier Nat. Park, West Glacier, USA, 17 May 1993, Ivie"), надкрылья, сзади; ширина 4,5 мм; 158 - Adinolepis (Ascioplaga) mimeta (Neboiss, 1984), comb.n., голотип, самец (MNHN, “Mt Koghi, 15.iii. 1978 (Delobel)”), надкрылья, сзади; ширина 2,6 мм. 
tshekardocoleid ancestor (Kirejtshuk et al., 2013).

The most important apomorphies of the order Coleoptera are manifested in the sclerotized forewings (elytra) and their venation ( $\mathrm{Sc}$ simple; RA convex and simple; RP simple, more concave than RA; $\mathrm{M}$ less convex than $\mathrm{R}$ and $\mathrm{CuA}$, simple, and basally fused with, but distally separated from $\mathrm{CuA}$; $\mathrm{M}+\mathrm{CuA}$ completely separated from radial stem; and $\mathrm{CuA}$ nearly reaching forewing apex), thorax (monolithic prothorax), legs (short trochanter and non-projecting coxae) (Kirejtshuk, Nel, 2013; Nel et al., 2013). All these characters are well expressed in the suborder Archostemata. The morphological characters shared by Coleoptera in body structure are very clear in the late Permian archostematans, viz. a dorsoventral compression of a compact body; thorax (prohypomeres); forewing (elytral) venation ( $\mathrm{CuA}$ and $\mathrm{CuP}$ separating at forewing base or very close to it; $\mathrm{CuP}$ relatively short or reduced, rather concave and simple; first anal vein convex and more or less parallel to posterior forewing edge; second anal vein of comparable convexity, shorter, but also more or less parallel to posterior edge; a third anal vein present, also closely parallel to posterior forewing edge in its distal part and fused with the second and first anal veins to constitute an 'adsutural line'); hindwing venation (automatic folding device and some autapomorphic features in venation patterns with the radial system diminished and anal one enlarged, see Kukalová-Peck \& Lawrence, 1993; Fedorenko, 2009); metacoxae extending on abdominal base and corresponding fusion of derivates of two basal abdominal sternites; modification of the abdomen (laterosternites); and the coordinated structural transformations of the organs of the pterothorax and abdomen to constitute an isolated subelytral space. Later, the subgroups of this suborder maintained many above-mentioned features in the condition close to the initial situation (Kirejtshuk et al., 2013). Characters of the Archostemata probably include the restricted number of antennomeres (usually 11-13), meso- and metathoraces (pterothorax) fused together im- movably; metathoracic flight motor; tegula lost; subapical abdominal segments (beyond $8^{\text {th }}$ one), invaginated genitalia and abdominal segments 8 and 9 of both sexes. The tegular or overlapping articulation of abdominal ventrites characteristic of both Tshekardocoleidae (Moravocoleus permianus Kukalová, 1969) and Cupedidae (many groups) could also be provisionally recognized as an apotypic feature for Archostemata.

The order Coleoptera is usually treated in composition of the superorder Coleopterida which could include also Strepsiptera and Skleroptera (Kirejtshuk, Nel, 2013) and which is traditionally linked to even joined with Neuropterida (frequently as the sister group) (Martynov, 1931; Hennig, 1981; Kristensen, 1999; Rasnitzyn, 2002; Kukalová-Peck, Lawrence, 2004; Labandeira, 2011; Peters et al., 2014; etc.). This concept has found some support from current molecular studies (Wiegmann, Kim, 2009; McKenna, Farrell, 2010; etc.). However, the early phyletic differentiations of holometabolans still remain rather unclear. Rohdendorf considered that the supraorder "Coleopteroidea" could be "descendants of the oldest carboniferous orthopteroids" (Rohdendorf, 1961: 294). In some phylogenetic reconstructions, the lineage Coleopterida deviates next after the lineage of Hymenopterida from general branch after splitting Holometabola and Caloneuridea (Rasnitsyn, 1980). Representatives of these superorders appear as the first holometabolans in the fossil record (Nel et al., 2013) and the data on the structure of the male genitalia (see below) are in accordance with this interpretation rather than others, because the Priacma-type aedeagus maintain more common features with the hymenopteran structure of this organ than those of other holometabolan groups (see above Chapter 9). It is worth noting that Mickoleit (1973) concluded that the secondary telescopic ovipositor, "vaginal palps in the Coleoptera may possibly represent a plesiomorphic form of the Neuropteroidian ovipositor" (Mickoleit, 1973: 38). This paleontological and morphological interpretation obtained also support in the results of molecular comparisons (up to sister 

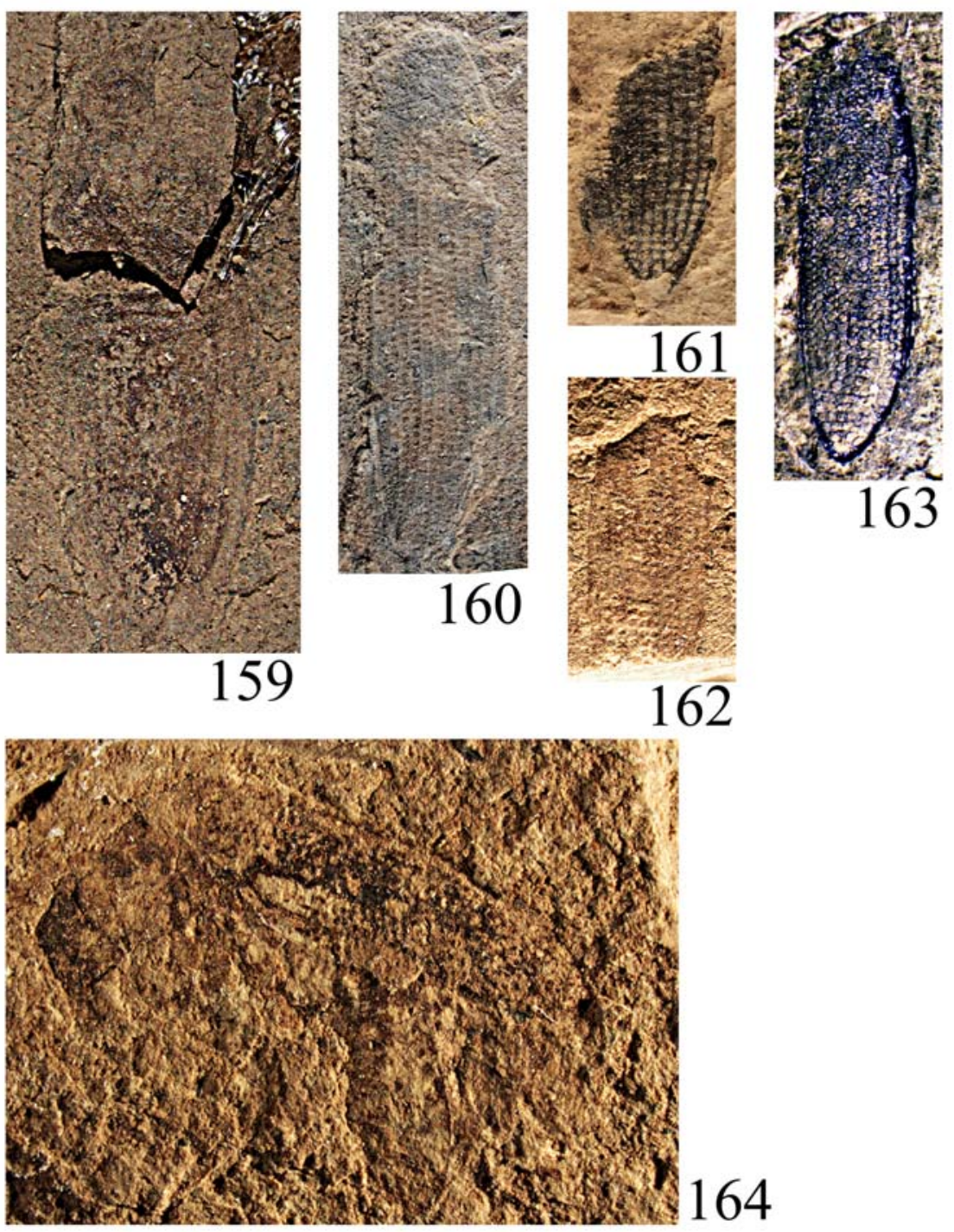

Figs 159-164. Fossil species of subgenenus Cainomerga subgen.n. (genus Mesocupes), photographed under Olympus SCX9 with camera Olympus; Paleogene, Paleocene; France, Menat: $159-M$. (C.) sp.1 ("MNHN.F.A. 57518"), dry print, length of body $12.0 \mathrm{~mm}$; $160-M$. (C.) sp. ("MNHN.F.A. 57519"), dry print, length of elytron $14.6 \mathrm{~mm} ; 161-M$. (C.) sp. ("MNHN.F.A. 57520"), dry print, length of posterior part of elytron $4.5 \mathrm{~mm} ; 162$ - M. (C.) sp. ("MNHN.F.A. 57521 ”), dry print, length of exposed part of elytron $4.1 \mathrm{~mm} ; 163-$ M. (C.) sp. ("MNHN.F.A. 57523"), dry print, length of elytron $4.6 \mathrm{~mm} ; 164-$ (?) M. (C.) sp.1 ("MNHN.F.A. 57522"), dry print, length of body, lateral $12.1 \mathrm{~mm}$.

Рис. 159-164. Ископаемые виды подрода Cainomerga subgen.n. (рода Mesocupes), сфотографированные на микроскопе Olympus SCX9 с камерой Olympus; палеоген, палеоцен; Франция, Мена: $159-M$. (C.) sp.1 (“MNHN.F.A. 57518”), сухой отпечаток, длина тела 12,0 мм; $160-M$. (C.) sp. (“MNHN.F.A. $57519 ”)$, сухой отпечаток, длина надкрылья 14,6 мм; $161-$ M. (C.) sp. (“MNHN.F.A. 57520”), сухой отпечаток, длина задней части надкрылья 4,5 мм; $162-$ M. (C.) sp. (“MNHN.F.A. 57521”), сухой отпечаток, длина выступающей части надкрылья 4,1 мм; 163 - M. (С.) sp. (“MNHN.F.A. 57523”), сухой отпечаток, длина надкрылья 4,6 мм; 164 - (?) M. (C.) sp.1 (“MNHN.F.A. 57522”), сухой отпечаток, длина тела сбоку 12,1 мм. 

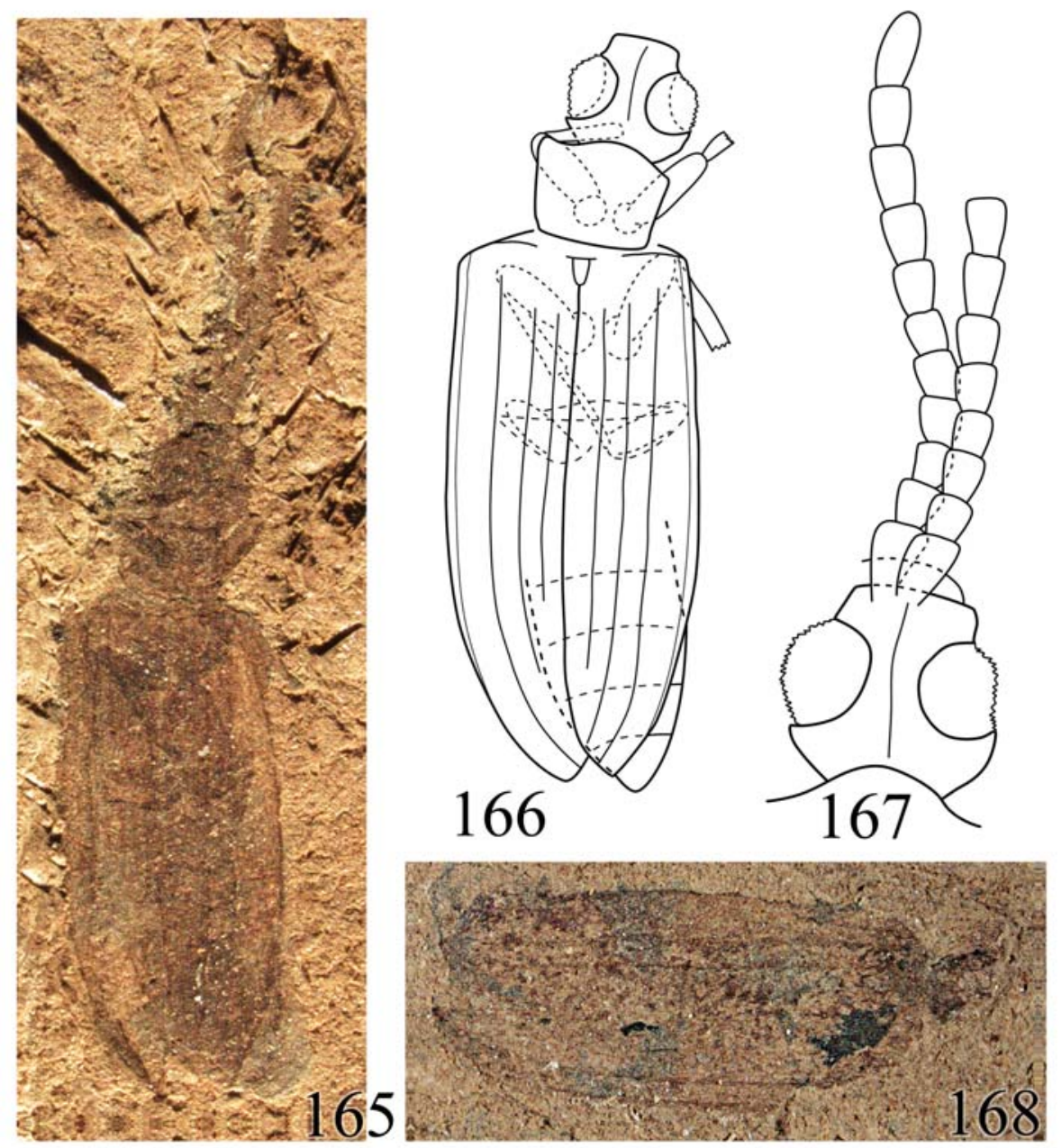

Figs 165-168. Menatops bartenevi gen. et sp.n. (“MNHN F.A. 57524”, print and counterprint), photographed under Olympus SCX9 with camera Olympus); Paleogene, Paleocene; France, Menat: 165 — dry print; 166 body, dorsal, with broken lines for outlines of below inner eye edges, sclerites of legs and abdomen; 167 head and antennae, dorsal; 168 - dry counterprint. Length of specimen $7.2 \mathrm{~mm}$.

Рис. 165-168. Menatops bartenevi gen. et sp.n. (“MNHN F.A. 57524”, отпечаток и противоотпечаток), сфотографированные на микроскопе Olympus SCX9 с камерой Olympus); палеоген, палеоцен; Франция, Мена: 165 - сухой отпечаток; 166 - тело сверху, сверху, прерывистой линией очерчены нижние внутренние края глаз, склериты ног и брюшка; 167 - голова и усики, сверху; 168 - сухой противоотпечаток. Длина тела 7,2 мм.

group relations: Savard et al., 2006; Castro, Dowton, 2007; Simon et al., 2012; etc.).

The studies of the Upper Carboniferous holometabolous larvae of the Moscovian age [Nel et al., 2013: Metabolarva bella Kirejtshuk, Prokin, Nel et Wappler, 2013 and Haug et al., 2015: Srokalarva bertei J. Haug, Labandeira,
Santiago-Blay, C. Haug et Brown, 2015 (=Srokalarva bertei Kukalova-Peck, 1997, nomen nudum)] make it possible to suppose that larvae looking like beetle ones came into the fossil record much earlier than the first true beetles, but at the age comparable with the findings of the oldest representatives of the probable stem 
lineages of hymenopterans and coleopterans (Nel et al., 2013). These larvae have some correspondence to many early Permian larvae from Tshekarda, among which the larvae of tshekardocoleids can be expected (Ponomarenko, 1969; Prokin et al., 2015). The structure of some of these larvae corresponds well to the opinion that larvae of oldest beetles were associated with tree trunks inhabiting inside substrate, having their structures similar to those of eruciform larvae of the Recent beetles (Ponomarenko, 1969, 1988; Crowson, 1981; Kirejtshuk, et al., 2013; Nel et al., 2013; etc.). However, Haug et al. (2015) considered that the Carboniferous larvae are members of the clade Neuropterida and they were "herbivorous as external foliage feeders" (Haug et al., 2015: 8). This opinion was explained by these authors, on the one hand, by the hypothetic reconstruction of mouthparts of these larvae, which, however, is rather uncertain and does not give a clear reason to suppose the larval diet, and, on other hand, by the findings of the Palaeozoic plants damaged by some arthropods by chewing. Nevertheless, the Recent members of the orders of Neuropterida are mostly predaceous and only the freshwater sisyrid larvae (Sisyridae Zalessky, 1932) feed on sponges (Porifera: Spongillidae Gray, 1867) and probably on bryozoans (Phylactolaemata). Labandeira (2011) regarded that Srokalarva could belong to the Antliophora and admited its feeding inside substrate. The interpretation of surface inhabitance of Srokalarva also contradicts to the concept by Lameere (1899) on origin of the Holometabola as result of certain transformations during individual development connected with splitting of places of larval inhabitance (concealed) and of place of adult ihabitance (open). The important circumstance is the probable traces of metapneustic respiratory system with an orifice at abdominal apex observed in Metabolarva bella which could testified its inhabitance in wet or even freshwater invironment (Nel et al., 2013). Among the modern holometabolans this respiratory type occurs in larvae of dipterans, coleopterans and hymenopterans. The coleopterous larvae are more probable pretenders to be linked with the
Carboniferous larvae by analogous or homologous structures, although all modern coleopterous larvae with metapneustic respiratory system are aquatic and very diverse in structure, but not eruciform (Nel et al., 2013). Ponomarenko (1988) following Lameere (1899) supposed that the ancestors of holometabolans were eruciform and had habitats different from those of their adults. The structure of Metabolarva bella with probable metapneustic respiratory system allowing living inside wet substrate is in accordance with such interpretation. If the ancestors of beetles were really associated with helophilous forest, their larvae could have metapneustic respiratory system allowing to be in wet interstices under bark and in wood.

\section{Phylogeny and historical develop- ment of the suborder Archostemata}

The oldest beetles known from the early Permian are currently included in the suborder Archostemata (Kirejtshuk et al., 2013). They have the forewings with more or less expressed remains of venation, which is frequently regarded as key for tracing the phyletic diversifications because of great conservatism of this structure. Ponomarenko (1969) divided the suborder Archostemata in the two phyletic cupedoid and schizophoroid lineages (later called the infraorders Cupedomorpha Ponomarenko, 2002, and Schizophoromorpha Ponomarenko, 2002, respectively). The former group is more similar to members of the oldest known beetles (Tshekardocoleidae) by structure of the elytra and general appearance (Ademosynidae Ponomarenko, 1968, Cupedidae, Permocupedidae, Taldycupedidae). This could have been somehow associated with structural transformations leading to a syndrome of polyphagan morphology (mostly on the basis of hindwing venation: see Ponomarenko, 1973b). This archostematan group, including both Tshekardocoleidae and Cupedidae, maintains more plesiomorphic characters than other beetles in the forewings, even in Recent forms. The other group of archostematan families (Schizophoromorpha: Asiocoleidae Rohdendorf, 1961, Catiniidae Ponomaren- 
ko, 1968, Rhombocoleidae Rohdendorf, 1961; Schizophoridae Rohdendorf, 1961, Tricoleidae) could have been better associated with Adephaga and Myxophaga and, therefore, according to Ponomarenko (1973b), they could be linked by phyletic relations characterized by the loss of "traces of an archedictyon" (presence of cells as transparent "windows" between veins arranged in a less modified pattern) and multiplications of long longitudinal rows of cells on the elytra at the early stages of diversification (during the Permian and Triassic). Later, the family Schizocoleidae Rohdendorf, 1961, has been added to the latter lineage (infraorder) (Kirejtshuk, Ponomarenko, 2016). Besides this, Ponomarenko (1969) regarded Micromalthidae as showing an unclear position within Archostemata. However, the archedictyon in the strict sense seems to have disappeared in the Holometabola before the emergence of an ancestor of the cohorte Coleopterida, since all other major holometabolan clades (Hymenopterida, Mecopterida, Neuropterida) show no true archedictyon at all. Kukalová-Peck \& Lawrence (1993) proposed the following phylogenetic hypothesis for the beetles \{Polyphaga + [Archostemata + (Myxophaga + Adephaga) $]\}$, which could be in some agreement with the fossil record. Taking into account the transformational rows in aedeagal structure and the pattern of wing venation, it could be provisionally suggested that the Cupedidae, the Micromalthidae, and the Crowsoniellidae with five abdominal ventrites, probably also the Jurodidae Ponomarenko, 1985 with six abdominal ventrites, supposedly belong in the cupedoid lineage of Archostemata together with the probable ancestor of Polyphaga, while Adephaga and Myxophaga could have originated within the schizophoroid lineage of this suborder.

All lineages of the archostematans seem to have emerged during the end of the Palaeozoic, although many characteristic groups appeared in the fossil record in the second half of the Triassic (Ponomarenko, 1969, 1995, 2004; Kirejtshuk, Ponomarenko, 2016). Therefore, the main diversifications of the order can be supposed to have happened during a compara- tively short time (second half of the Permian to the earliest Triassic). Various structural types adapted to different ecological niches had already been represented among the late Permian members of these lineages, in addition to the oldest xylomycetophagans from Tshekardocoidae (Kirejtshuk, 1991; Ponomarenko, 1995; Kirejtshuk et al., 2013). Most findings of late Permian beetles originated from Laurasia and only few are known from South African deposits (Pinto, 1987; Geertsema, van den Heever, 1996; Ponomarenko, Mostovski, 2005). The Mesozoic was the era of archostematan boom. The greatest diversity of families and genera of this suborder is observed during that era, although some Palaeozoic groups (viz. Tshekardocoleidae, Asiocoleidae, Permocupedidae and Rhombocoleidae) had disappeared earlier or near the Palaeozoic to Mesozoic boundary (Ponomarenko, 1969; Kirejtshuk, Ponomarenko, 2016). Most Mesozoic findings of archostematans also originated from Europe and Asia, although their total range is much wider than that of the Palaeozoic ones and includes many forms from Australia (Dustan, 1923; Jell, 2004), few taxa from Brazilian Crato from the Early Cretaceous (Wolf-Schwenninger, Schawaller, 2007; Kirejtshuk, Nel, in preparation), Argentinian Río Gualo from the early Triassic (Martins-Neto et al., 2006a, b) and few from the Cretaceous deposits of North America (Ponomarenko 1969b; Lubkin, 2003; Kirejtshuk, Ponomarenko, 2016). The highest diversity (number of archostematan genera and species) is found in the Jurassic deposits, to progressively decline thereafter. To the end of the early Cretaceous, the suborder Archostemata consisted of families represented in the extant fauna by a smaller number of genera and species.

The family Cupedidae could be regarded as one of the groups "closely" related to the family Tshekardocoleidae. Ponomarenko (1969) mentioned that the former mostly differed from the latter by the reduction of CuP in the elytra, by two rows of cells between all primary veins of the elytra, and by open procoxal cavities. He regarded Permocupedidae as a close relative of Tshekardocoleidae. The elytra of both latter 
families show remains of a $\mathrm{CuP}$, less regular (sometimes with a multiplied number and varied sizes of the cells) and not always strictly double rows of cells on the interspaces between the primary veins, without fusion of A1 and $\mathrm{CuA}$ at the apices; although the species of Permocupes Martynov, 1933 (Permocupedidae) have both $\mathrm{A} 1$ and $\mathrm{CuA}$ fused, while not all Triadocupedinae, Cupedinae, and some Ommatinae show this fusion very clearly (see above "Notes on the taxonomy and systematics of Cupedinae"). Besides this, Permocupes species demonstrate almost regular double rows of cells on each interspace at least between A3, A1, $\mathrm{CuA}, \mathrm{M}$ and $\mathrm{R}$ (as those in many Cupedidae). According to Ponomarenko (1969), representatives of the Tshekardocoleidae and Permocupedidae, presumably also Taldycupedidae, had the procoxae closed posteriorly. This is the reason to suggest an "ancestor" of Cupedidae closer to the Permocupedidae rather than to any other archostematans (Ponomarenko, 1969). However, the structure of the prothorax of the Permian beetles is generally poorly known, while the presence of the posteriorly closed procoxae among all the Palaeozoic groups remains more or less hypothetic because of scarcity of complete fossils studied. Rohdendorf (1961) proposed to unite Cupedidae and Permocupedidae, but Ponomarenko (1969) later restored the family rank for both. However, the relations between these families still need revision after additional studies on known and new materials accessible in different collections. Ponomarenko (1969) considered the genus Permocupes with the elytral $\mathrm{CuA}$ and $\mathrm{A} 1$ fused at the apices (as in most cupedines) as "progressive" among permocupedid genera. However, if we admit this character as synapomorphic for both Permocupedidae and Cupedidae while separate ends of these veins as having appeared secondarily, a hypothesized sister-group relation of these families from a single tshekardocupedid lineage may be recognized as more probable. Ponomarenko (1969) regarded that the first cupedids should have had wide epipleura, also characteristic of the Triadocupedinae, but not so frequent in Cupedinae and Ommatinae. This feature is usually associated with a stripe of more or less large cells between $\mathrm{Sc}$ and the lateral (true anterior) elytral edge and present in many tshekardocoleids demonstrating explanate sides of the elytra. One row of cells also occurs in many triadocupedines and some members of both cupedines and ommatines. Thus, these submarginal cells could have been initial while their lack in many cupedines and ommatines with narrow sides (as in modern species) is a secondary homoplastic trait.

Unfortunately, the aedeagi of tshekardocoleids, permocupedids and taldycupedids remain unknown. Moreover, many Permian groups are only known from elytra which demonstrate frequent parallel transformations and cannot be used for reliable conclusions on their phylogenetic relations. Therefore, it is impossible to determine whether these families had male genitalia similar to those in Priacma or Cupes. This point is important to define a divergence in the lineage maintaining the probably plesiomorphic Priacma-type aedeagus and the lineage (clade) with the apomorphic Cupestype aedeagus which corresponds to the roots of all other coleopteran groups. It is difficult to admit that the appearance of the Priacma-type aedeagus is a result of instauration of the ancestral condition of cupedines which could have appeared from the clade uniting at least the ommatines and cupedines, i.e. it is difficult to consider the Priacma-type aedeagus as a derived form the "plesiomorphic" (if it can be admitted) cupedine type. On the other hand, as the ontogenetic differentiations proceed the same way in both sexes (Tichomirova, 1981), any crucial change in this process' sequence in one sex should cause correlated changes in the opposite sex. The existence of a secondary telescopic ovipositor in Tshekardocoleidae (Kirejtshuk et al., 2013) suggests that the male genitalia of this group were also already invaginated. The ovipositor in Priacma remains still undescribed.

The Cupedinae, including the forms with both Priacma-type and Cupes-type aedeagi can also be regarded as plesiomorphic in relation to the male genitalia of Ommatinae apparently 


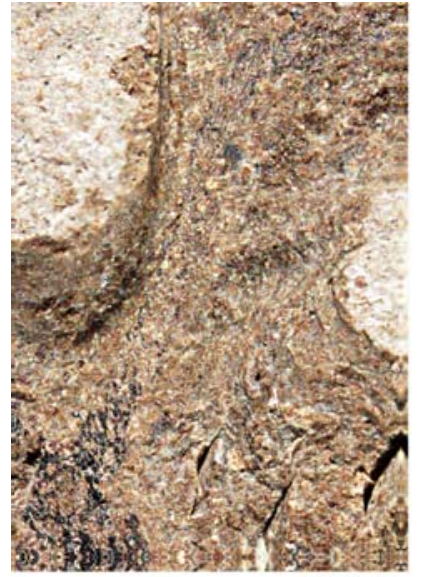

169

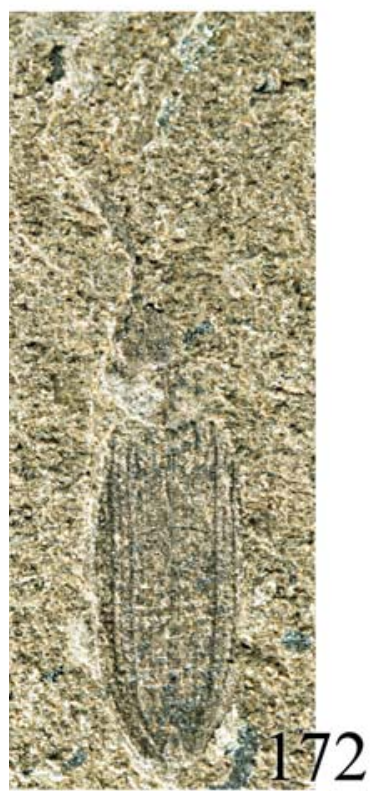

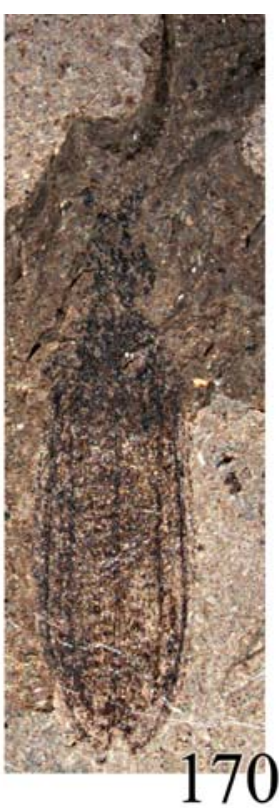
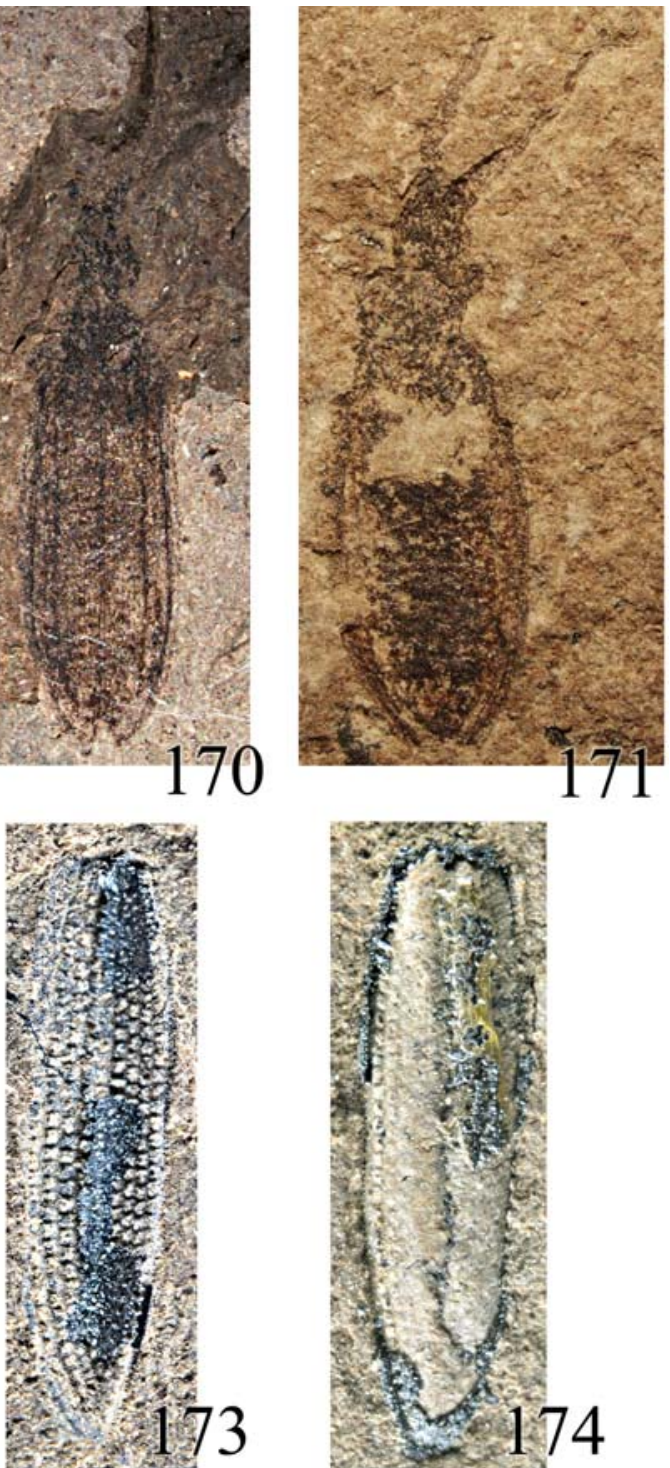

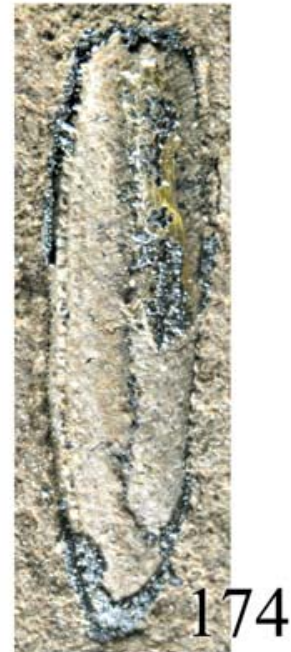

Figs 169-174. Fossil species of subfamily Cupedinae, photographed under Olympus SCX9 with camera Olympus; Paleogene, Paleocene; France, Menat: 169-172 - Cupes manifestus Kirejtshuk, Nel et Colomb, 2010: 169 - "MNHN.F.A. 57525", head and antennae on dry print; 170 - same specimen, dry print, length of body $8.9 \mathrm{~mm} ; 171$ — "MNHN.F.A. 57526", dry print, length of body $7.8 \mathrm{~mm} ; 172$ — "MNHN.F.A. 57527", dry print, length of body $8.9 \mathrm{~mm}$; 173-174 —Genus incertus sp.4: 173 - "MNHN.F.A. 57529", dry print, length of elytron $5.9 \mathrm{~mm} ; 174$ - "MNHN.F.A. 57530", dry print, length of elytron $6.2 \mathrm{~mm}$. Рис. 169-174. Ископаемые виды подсем. Сupedinae, сфотографированные на микроскопе Olympus SCX9 с камерой Olympus; палеоген, палеоцен; Франция, Мена: 169-172 - Cupes manifestus Kirejtshuk, $\mathrm{Nel}$ et Colomb, 2010: 169 — "MNHN.F.A. 57525", голова и усики на сухом отпечатке; 170 - тот же экземпляр, сухой отпечаток, длина тела 8,9 мм; 171 — “MNHN.F.A. 57526", сухой отпечаток, длина тела 7,8 мм; 172 - "MNHN.F.A. 57527”, сухой отпечаток, длина тела 8,9 мм; 173-174 - Genus incertus sp.4: 173 - “MNHN.F.A. 57529”, сухой отпечаток, длина накрылья 5,9 мм; 174 - "MNHN.F.A. 57530", сухой отпечаток, длина надкрылья 6,2 мм. 
lacking traces of a volsellar plate, "digitus volsellaris", "cuspis volsellaris" (see above Chapter 9). Edwards (1953a), following the Snodgrass' terminology of the hymenopteran aedeagal structures (Snodgrass, 1941), considered these three structures together with the parameran plate and a broad sclerite at the base of the parameres (see Fig. 131) as having participated in the formation of a phallobase (basal piece), like it may have arisen in the Hymenoptera, as we have shown above. On the other hand, some researchers regard the membranous appendages of the parameres in Micromalthidae and Crowsoniellidae as homologous with the derivative aedeagal structures of the cupedids (Crowson, 1976; Hörnschemeyer, 2009). Hünefeld et al. (2011) regards that the "potential autapomorphy of Archostemata is the median division of the sclerotization of sternum IX, which is conspicuous in Tetraphalerus. In Cupedidae, two alternative conditions are found: an unpaired sternal plate is present in most species of this family, but paired ventro-lateral sclerites are found in the small genera Priacma (1 sp.) and Paracupes (2 spp.)." (Hünefeld et al., 2011). This hypothesis is not evident even in the case of ignorance that the embryonic base of abdominal sterna have a paired nature (Tichomirova, 1991) and that many genital structures of both sexes derivated from abdominal sclerites have paired divisions (Tanner, 1927; Matsuda, 1976; Crowson, 1981; etc.) because of paired embryonic base and genetics (Lewis et al., 2000). As some polyphagans show remains of these structures as well, we may suppose that the aedeagus of the modern ommatines might have originated independently from that in polyphagans, some groups of which also maintain such remains (see above Chapter 9). Sharp and Muir (1912) postulated that the adephagan type of aedeagus without a phallobase (op. cit. 1912: 622: "the basal-piece is greatly reduced, or entirely membranous") has "no approximation" to that in the cupedids and regarded it as rather specialized. Crowson (1981) considered that the polyphagans may have obtained the phallobase through fusion of the gonocoxites as an apomorphy of this suborder. Although Lawrence (1999: 384) supposed that "the absence of a phallobase may be a synapomorphy of Archostemata + Adephaga + Myxophaga", some homologies in different structures showing the formation of a phallobase can be traced in the aedeagi of the Priac$m a$-type, the Cupes-type and some polyphagans. This suggests that the volsellar complex and phallobase could present in some archostematans and polyphagans a symplesiomorphy while it could have been reduced (as a volsellar plate, "digitus volsellaris", "cuspis volsellaris" or their derivates) in the adephagans and myxophagans. Fedorenko \& Ponomarenko (2012) found a schizophoroid hindwing from Isady (late Permian, Tatarian, Poldarsa Formation), together with a hindwind of a cupedomorph beetle. Taking this into account, it is possible that the ancestors of both Adephaga and Myxophaga could have been related to the Schizophorimorpha, while the ancestor of Polyphaga could have been related to the lineage of the Cupedidae, probably during the late Permian when beetles had already become rather diverse (Volkov, 2012; Ponomarenko, 2015; etc.). The differences in their aedeagal structures could be a trace of the sequence in the old divergence of this lineage into a sublineage (leading to Recent Priac$m a$ ) and a different one which includes the most well-known cupedines and a probable polyphagan "ancestor" with a Cupes-like aedeagus (see above Chapter 9). Thus, the basal divergences of the order can be defined as follows: Tshekardocoleidea + \{Schizophorimorpha + [Cupedinae + (Ommatinae + other families of Cupedomorpha)]\}. The traditional phyletic link of Schizophorimorpha to Adephaga and "Myxophaga" and, accordingly, that of Cupedomorpha to Polyphaga can be admitted perhaps as the most probable hypothesis (Ponomarenko, 1973b, 2002; Kirejtshuk, 1991; etc.).

On the phylogeny and historical development of the subfamily Cupedinae

The hypothetic generalized pattern (groundplan, or archetype) of elytral venation seems to be most stable among members of the subfamily Cupedinae compared to any other archostem- 
atan subfamily with more than ten described members. It seems to include a weak or usually reduced Sc (if raised), a long and weak $\mathrm{R}$ running along the lateral curve of the elytra and ending at the very apex (or fusing to A1 just at apex), a long $\mathrm{M}$ subparallel to $\mathrm{R}$ and fusing with the latter at the apex, a long $\mathrm{CuA}$ subparallel to the suture and fusing to A1 at the apex, a long A1 subparallel to the suture and reaching to the latter's edge, but somewhat deviating externally at the scutellum, a short A2 subparallel to the scutellum and slightly surpassing its apex along the suture. The most usual place of change in the elytral disc plane to sloping sides proceeds along $\mathrm{M}$. Sc and R are frequently very weak or even scarcely traceable. The space between Sc and the lateral (initially anterior) edge of the elytra seems to be occupied by a row of cells located on an explanate part of the elytral sides (observed in Kirghizocupes, Priacmopsis, some Anaglyphites, etc.) while the interspaces between the long primary veins (A3, A1, CuA, M, $\mathrm{R}$ and $\mathrm{Sc}$ ) bore a double row of cells. There are some modes of transformation of this pattern. One of these modes includes changes when A1 does not to reach the lateral edge of the elytra and ends up in the distal part of the elytral suture (in many Triadocupedinae and Ommatinae with known venations, but only in the genus Prolixocupes among Recent Cupedinae). Such differences in the ending of the primary veins can also be observed among members of Permocupedidae, Taldycupedidae, and Ademosynidae. So it can scarcely be regarded as a feature of great phylogenetic meaning. Another mode consists of an independent ending of all primary veins along the apical part of the lateral (true anterior) edge of the elytra, which is not infrequent among ommatines, but also occurs in the cupedine genus Miocupes with parallel primary veins, some cupedine groups with gradually approaching primary veins but without fusion at the apices (particularly members of the genera Chalepocarabus, Kirghizocupes and Latocupes, but also the subgenera Anaglyphites stat.n. and Mesocupes s.str., etc.). Such a trend in elytral venation is also observed in some other archostematan families (Taldycupedidae, Permocu- pedidae, Tricoleidae, Rhombocoeidae, etc.). They likewise have the primary veins ending independently along the lateral edge of the elytra. This trend could supposedly be reversible in some cases of an incomplete reduction of veins. Another very frequent transformation is the homoplastic reduction and disappearance of a short A2 and a correspondingly short row of cells at the scutellum. Finally, in some cases the vein traces become completely obliterated (the cupedine genera Mesocupes and Chalepocarabus) and make the elytra look similar to those in some Permian groups. Such obliterated elytral veins, coupled with the disappearance of clear rows of cells, have happened in many archostematan families and is to be recognized as a sequence of homoplastic transformations which without additional evidence, can hardly be regarded as a ground for phylogenetic conclusions.

A rather extraordinary transformation of elytral venation is found in the Cenozoic Cainocups aixensis gen. et sp.n. This species had four long primary veins on a flat elytral disc, with an unusual pattern of their fusion, and also 12 long longitudinal rows of cells, instead 9 or 10 as typical of Cupedinae. This species of an unclear position between Cupedinae and Ommatinae shows inflections to the steeply sloping lateral sides along $\mathrm{R}$ (but not $\mathrm{M}$ ) and the external four rows of cells on a very wide sloping elytral side (see above the description of this new genus and species in Chapter 7). Nevertheless, the absence of such a type of elytra in the previous fossil record can suggest that this type is scarcely old in origin.

The overlapping abdominal ventrites (characteristic also of tshekardocoleids) can be recognized as plesiomophic for cupedines, because it occurs in both other cupedid subfamilies (Triadocupedinae and Ommatinae) as well as the abutting type. The subvertical abdominal laterosternites known both in Ommatinae and Cupedinae with rather convex elytra seem to have appeared during the early period of diversifications of the early cupedids and could be a synapomorphy for the family in general. The fossil specimens with steep elytral sides should 
certainly have such subvertical laterosternites, including the oldest cupedines (Kirghizocupes). Comparative studies of structures of the Recent Cupedinae and Ommatinae show that the modern Omma and Tethrapalerus maintain a greater number of plesiomorphic characters (Hörnschemeyer et al., 2006) which, according to the cladogram created on the basis of a matrix by these authors, could form the sister group to all other Recent archostematans (including Crowsoniella Pace, 1976 and Micromalthus LeConte, 1878, but not Sikhotealinia Lafer, 1996). Futhermore, Beutel et al. (2008: 292) found that the "Ommatidae" could be "placed as the sister group of the remaining Archostemata, including the extinct families Ademosynidae, Schizophoridae and Catiniidae. The monophyly of this clade is supported by one apomorphy of adults, the absence of the tentorial bridge, and by seven apomorphies of larvae. The larval features strongly support a clade comprising Micromalthidae and Cupedidae, but not Ommatidae". Unfortunately, because tentorial bridges of adults are not available in most fossils, also because only larvae of Micromalthidae are known among fossil archostematans (no fossil cupedid larva has been found so far), and because a comparison based only on a few Recent archostematan larvae is certainly not enough for a reliable reconstruction of the whole phylogeny of recent and fossil taxa, the hypothesis proposed by these authors can scarcely be tested in a proper way without data on fossil larvae. Atkins (1958a), among other things, noted that Priacma serrata lacks membranous lobes on the tarsomeres, but this species shows what seem to be reduced or rudimentary empodia. At the same time, extant members of Omma have distinct bisetose empodia. It is noteworthy that some recent comparative studies conclude that "representatives of Archostemata are characterized by many derived features of the head, which are partly due to a more exposed lifestyle and partly to specialized pollen-feeding habits" (Hörnschemeyer et al., 2002:312). However, the particularly stable morphotype of many taxa in the subfamily $\mathrm{Cu}$ pedinae beginning at least from the Middle/late Triassic gives reason to suggest that both "life- style" and "feeding habits" of cupedine larvae and adults may have maintained stable for a very long time (at least from the Middle/late Triassic) and they could have been basal for further changes in both "lifestyle" and "feeding habits" of the polyphagans which might have derived from a cupedine-like ancestor. Crowson (1975) regarded that the boring holes in trunks of Araucarioxylon Knowlton, 1888 (Araucariaceae) "in petrified forest" of Arizona could have being made by cupedine larvae. Such habits could be associated with an appearance of resins in the Mesozoic conifers caused by protection from beetle attacks. Thus, similarity of mouthparts and other structures in the Jurassic and modern cupedines can be explained by similar mode of life including regular visiting plant generative organs. The archostematans used for comparisons by neontologists mostly represent the modern fauna, i.e. only few terminal phylogenetic branches. In particular, the extant cupedines, except for Priacma serrata, with similar head tuberculation patterns and partly covered antennal insertions, seem to be descendants of the same phylogenetic lineage of the subfamily. The difference in the male genital structures of Priacma and Gracilicupes, on one hand, and those of other genera with known male genitalia, on the other hand, seems to support the viewpoint that these lineages which produced the Recent (1) Priacma and (2) other genera represented in the modern fauna must be rather old, although some diversification events in these genera could be quite recent, most probably during the Cenozoic. This was the reason for an unresolved polytomy in the strict consensus tree obtained by Beutel et al. (2008). This latter paper, as well as some others published by specialists on the modern fauna, contain no studies on fossil beetles and consider the characters of Recent species alone, the results being directly and uncritically extrapolated on fossil species, with some features of Recent representatives frequently being assigned to fossils. However, the distribution of plesiotypic and apotypic characters available in the extant members of a group rarely corresponds to the sequence of diversifications, at least such situa- 
tion is clearly observed in cupedines whose fossil diversity is incommensurably greater than recent diversity. After a rather broad comparison of many species of the modern fauna even more paradoxical interpretation have been obtained by Lawrence et al. (2011: 65): "Within the Archostemata, neither Ommatidae nor $\mathrm{Cu}$ pedidae is monophyletic, Ommatinae (comments: these authors only mean Recent species of Omma) forming a clade with Cupedinae (comments: these authors only mean all Recent cupedines except Priacma serrata) and Tetraphalerinae (comments: these authors only mean Recent species of the genus Tetraphalerus) with Priacminae (comments: these authors only mean Priacma serrata), while Micromalthidae is sister to the remaining taxa." Not surprisingly, such a hypothesis of relationships fails to correspond to what we could observe here. Nor can it be applied to the fossil material examined or reexamined in the present paper.

The fossil specimens studied so far allow for the structural cupedine type or cupedine morphotype to be admitted as having evolved at a very early stage of the historical development of the family, which also included a plesiotypic pattern of elytral venation, a significant convexity of the body, the elytra with steeply sloping sides and reduced epipleura, and also the Priac$m a$-type male genitalia. The Priacma-type aedeagus is to be recognized as probably plesiomorphic because it is hardly possible at the moment to admit a reversed transformation of the derived and less complex cupedine type back to the plesiomorphic and more complex Priacmatype. If the characters accompanying the plesiotypic aedeagus could also be considered as somewhat plesiotypic, the similarities of the oldest cupedines to Priacma serrata may tentatively be postulated as general features of cupedine morphotype.

The Middle/late Triassic Kirghizocupes, one of the oldest cupedine genera, shares with Priacma serrata the rather slender medium-sized body, the more or less steeply sloping sides of the elytra (but apparently not as vertical as in Cupes and its closest allies), the ground-plan elytral venation pattern), 10 (or 11) long longi- tudinal rows of cells on the elytra, the tuberculate head and (sub)filiform antennae (see above "Notes to Kirghizocupes" and Chapter 9). However, Kirghizocupes differs from Priacma in one additional row of cells visible in some prints just between Sc and the lateral edge of the elytra, the reduction or lack of fusion of primary veins at the elytral apices, the rather long head with paramedian convexities behind the antennal insertions forming a more or less expressed $\mathrm{Y}$ shaped depression in the anterior part of the frons, the open antennal insertions, the rather wide pronotum and very widely (sub)explanate sides. Therefore, the distinguishing characters of Priacma can preliminarily be recognized as apomorphic, albeit the lack of fusion of primary veins at the elytral apices in some specimens of Kirghizocupes is to be regarded as secondary. It is noteworthy that the above distinguishing characters of Kirghizocupes are characteristic not only of members of Cupedinae, but also of Asimma and Pterocupes, both of uncertain positions, partly also of some other groups initially included in triadocupedines. Thus, these characters could provisionally be considered as symplesiomorphic. The very wide explanate pronotal sides occur mostly in the Triassic cupedines (Kirghizocupes and Asimma) and triadocupedines (Cupesia Ponomarenko, 1966, Platycupes and Triadocupes). Among other cupedines, only Latocupes (including Pulchicupes) has such a wide pronotum with so widely explanate sides, which seems better to be interpreted as a secondarily developed similarity. The comparatively long head occurs in the cupedine Kirghizocupes and triadocupedine Procupes Ponomarenko, 1966, as well as many Ommatinae. The comparatively deep Y-shaped depression in the anterior part of the frons associated with the peculiar convexities on the head are observed in many Mesozoic cupedines. Ponomarenko (1966) mentioned this character only for Mesocupoides (a junior synonym of Kirghizocupes) among Triassic cupedids, but the elongate paramedian convexities behind open antennal insertions can be traced back to numerous Mesozoic cupedines, triadocupedines and ommatines; in triadocupedines with a wide head, 
the lateral branches of this depression barely fail to form a transverse groove with a slight (very blunt) angle in the middle. Probably this structural peculiarity cannot be unambiguously interpreted in all cases; however its distribution across many groups of the family allows to suppose some probability of a symplesiomorphy to be admitted for most of these cases. The open antennal insertions are somehow structurally associated with the tubercles and depressions on the frons (considered above). If the convexities or tubercles are not raised or located behind the antennal insertions, they leave the antennal insertions open. If these convexities or tubercles shift anteriorly, they cover the posterior edge of the antennal insertions while the $\mathrm{Y}$ shaped depression on the frons becomes displaced further forward, where the frons is transformed into a small triangular depression before the antennal insertions (as in all Recent cupedines). So the formation of covered antennal insertions seems to have frequently been homoplastic, albeit in the Recent species of most genera similar to Cupes they may have had a phylogenetic succession because of close relationships expressed in a considerable similarity of most Recent taxa (see above Chapter 4).

All three subfamilies of the family Cupedidae (Triadocupedinae, Ommatinae and Cupedinae) appeared in the fossil record as clearly defined forms only since the Middle/late Triassic. The Triadocupedinae is only represented in the Middle/late Triassic while the Ommatinae and the Cupedinae have survived until now. Besides this, beginning from the Middle Triassic, elytra with characteristic venation patterns and steep sloping of elytra have been found, but regrettably they are impossible to accurately assign to any of the subfamilies (see above Chapter 8). Nevertheless, the lack of earlier evidence of cupedines seems better to be explained by scarcity of material obtained from the early Triassic. The possibly plesiomorphic character of the aedeagus in Priacma might have been inherited from the ancestor of Holometabola. Therefore, the cupedines could have emerged from a taxon with a similar aedeagal type. Plausible candidates could be either an early Permian tshekarcocoleid or any late Permian related group. The male genitalia of such groups are still unknown (see above) and no Triassic cupedid with exposed male genitalia has been recorded. It seems likely that a close relative of Permocupes and the "ancestor" of cupedids may have had a sister-group relation. Besides this, two alternative evolutionary scenarios could be presumed. Either taxa directly related to the Palaeozoic Tshekarcocoleidae or any late Permian group reached the Middle/late Triassic without representation in the fossil record to give rise to the Cupedidae, or the Mesozoic Cupedidae appeared during the times when the Palaeozoic groups were more numerous, but the cupedids had failed to enter fossil deposits till the Middle/late Triassic. The latter option seems to be more viable, taking into account the significant similarities between the elytra of Permocupes and many cupedids (see above).

Changes of the number of long longitudinal rows of cells on the elytra may have followed a progressive decrease in number from 10 or 11 to nine. This process is characteristic of different groups and occurs independently, as it was demonstrated in the modern groups by Neboiss (1984). The opposite change, i.e. an increase of the number of rows of cells could also be admitted. In Cainocups aixensis sp.n., the number of long longitudinal rows was increased to 12 because the primary vein $\mathrm{R}$ adjoined, through a longitudinal inflection, the flat disk of the elytron and the steep sloping of the elytral sides in this species proceeded along $\mathrm{R}$, but not along $\mathrm{M}$ (as usual in cupedines). Nevertheless, it seems more reasonable to provisionally join C. aixensis sp.n. with Cenozoic archostematan groups rather than search for another explanation for placing this taxon in the classification of the suborder.

Many structural details easily accessible in modern cupedines simply cannot be analyzed to the same extent in fossil representatives. Atkins (1958a) considered that the living Priacma serrata have maintained the conditions that are more archaic than those occurring in the members of the genus Cupes. This author mentioned that, in Cupes, abdominal ventrites 2 and 3 are 
connate, without any apparent suture between them. Unfortunately, this structural peculiarity which could be important for tracing the phylogeny is not testable in fossils. Nevertheless, this conclusion strongly contradicts the timing of the distribution of the overlapping (tegular) type of articulation in the abdominal ventrites among the Permian and early Mesozoic archostematans, which can be traced not only in most fossil cupedids (including many fossil members of Cupes), but also in Permian tshekardocoleids, as well as the distribution of the abutting (flat) type present in Priacma serrata, other cupedids and archostematans. The venation of the hindwings in Priacma serrata is more complex than in other cupedid hindwings previously described, there being more cross-veins and six enclosed cells (Atkins, 1958b). The persistence of the more complex venation with numerous crossveins is usually interpreted as plesiotypic. According to Atkins (1958a: 533), "Priacma serrata has a larger number of cross veins than Cupes, which might indicate that Priacma is the more primitive of these two genera". Of course, this agrees with differences in the type of aedeagus (see above Chapter 9).

Another interesting aspect is the difference in the pair of genera Paracupes s.lato and Priacma, as well as in the pair of subgenera Paracupes s.str. and Paracupoides subgen.n. The former pair shows many similarities in external characters and a striking contrast in structure of the male genital sclerites. If the divergence in the genital structure of the common "ancestors" of these groups happened long time ago, the similarities in external structure should be supported by a certain ecological conditionality to maintain such a great stability. Such conditionality could be great conservatism in habitat preferences and the mode of life (lifestyle) at least over two hundred million years (since the Middle/late Triassic). Similar cases are represented not only in the ommatine Omma and Tetraphalerus, but also in the genera Jurodes Ponomarenko, 1985 (early-late Jurassic) and Sikhotealinia (modern) from the archostematan family Jurodidae. Thus, such a conservatism in structure and probably also in ecology and bion- omy is somehow more or less characteristic of cupedomorphan Archostemata in general. At the same time, this conservatism during such a long time is combined with a comparatively rapid transformation in the types of elytra discovered in the studies of the pair of Paracupes s.str. and Paracupoides subgen.n. (see above Chapter 6). This reccurrence of the structural type of not too closely related "groups" (Paracupoides ascius comb.n., on the one hand, and modern species of the genera near Cupes, on the other hand) could be accounted for by a morphocyclic process of conservative ground-plans causing some convergence (Emel'yanov, 2000), because it seems to be completely impossible to link genealogically one of these groups (Paracupes s.str. and Paracupoides subgen.n.) to Priacma and the other to Cupes. In a formal sense, this could be made using a matrix of the characters traditionally used in a cladistic analysis of Cupedinae (e.g. Hörnschemeyer, 2009). It is noteworthy in the context of the pairs considered that the oldest of the known cupedines had their elytra with steeply sloping sides and 10 long longitudinal rows (Figs 109116) like those in Cupes and Paracupoides subgen.n., rather than those in Priacma and Paracupes sensu str. Thus, the elytra with steeply sloping sides similar to those in Recent Cupes could have appeared many times and scarcely manifest a reliable evidence of common ancestry without additional, more reliable support. The next type of similar differences can be observed in the elytra of the subgenus Anaglyphites stat.n. Mesocupes (Anaglyphites) capitatus comb.n. shows a row of cells between elytral Sc and the lateral edge (Figs 95-98), whereas the elytra of $M$. (A.) admotus comb.n. and $M$. (A.) clavatus comb.n. (Figs 101-102) bear densely tuberculate (crenelate) stripes along the lateral edge, similar to those in Priacma and Paracupes s.lato. These types of difference demonstrate a mosaic distribution of many characters among Recent and fossil cupedines.

The subfamily Cupedinae, as cupedids in general, certainly had a much greater significance in the Mesozoic faunas than in the Cenozoic ones. Having appeared in deposits since the 
Middle Triassic, the cupedids in general represent up to one-third of the coleopterous remains in the Jurassic deposits, the other greatest proportions being comprised by schisophoroids from Archostemata and various polyphagans (mostly elateroids) (Ponomarenko, 1995, 2002, 2003; etc.). Cupedidae as a major and the bestknown Mesozoic group occurred only in comparatively hot climatic zones (Ponomarenko, 2016). The Recent representatives of that family, however, do not clearly show such preponderance. All extant cupedids with known bionomy exist owing to the wood of angiosperms, a plant group absent in the Jurassic and earlier. Changes in food plants seem to have not become effected in structural features of the family. Therefore, the ecology and bionomy of its fossil and Recent members, despite the above-mentioned differences, were and probably still are more dependant on the structure of wood tissues, also on the fungal and microbial compositions associated with wood rather than the systematic position of food trees.

The triadocupedines disappeared in the fossil record at the end of the Triassic (Kirejtshuk, Ponomarenko, 2016) while both other subfamilies have reached the present times. They are now represented by a small number of species regarded as relict groups scattered in a mosaic pattern across the areas with temperate and subtropical climates. At the same time, the cupedines (31 species) are more diverse in the modern fauna than ommatines (only six species). Data on the Cenozoic faunas of cupedines are still scant and many species already collected and deposited in scientific collections are still awaiting a study. At least, in addition to the published cupedine species (Gersdorf, 1976; Tröster, 1993; Kirejtshuk, 2005), some undescribed species from the Eocene deposits which could mostly belong to Cupes, as well as some others undescribed genera are known to the authors from Baltic amber (Museum of Amber, Kaliningrad, ZIN and several private collections), Messel (SFNFM) and Eckfeld (LNNR). In addition, separate apices of cupedine elytra have been revealed in younger outcrops, i.e, the boundary between the Eocene and Oligocene of
Bembridge Marls (Ponomarenko, Kirejtshuk, in press) and the latest Oligocene of Aix (Cainocups aixensis sp.n.); the youngest cupedine remains are represented by Cupes praeglacialis from the late Pliocene of Willershausen, although its generic assignment needs a further revision. Thus, during the Neogene the subfamily Cupedinae can be supposed to have declined, probably in accordance with global climatic changes with reinforced seasonality and zonality. In Europe, the Cupedinae could have disappeared during the Pleistocene due to glaciations. At least in Europe, this group survived the Pliocene global cooling.

The Paleocene fauna of Menat seems to have had a considerable representation of Cupedinae, consisting of some genera as remains of the Mesozoic fauna [at least Mesocupes (Cainomerga subgen.n.)], although at the same time some close relatives of the modern fauna seem to have also been represented by Cupes species. This representation should be associated with forest ecosystems around the place of their deposition. The general composition of beetles in the outcrops of Menat includes a significant proportion of weevils (more than half of beetle remains), also many specimens of Cerambycidae Latreille, 1802, Elateridae Leach, 1815, Nitidulidae Latreille, 1802, Buprestidae Leach, 1815, eumolpine-like leaf beetles (Chrysomelidae Latreille, 1802) and some other arboreal groups which certainly were dominant at that locality at the time of deposition (Nabozhenko, Kirejtshuk, 2014).

\section{Conclusions}

1. Taxonomic and phylogenetic aspects:

- Cupedinae represents one of the oldest groups of the order and some of its forms maintain traces of "pre-coleopteran" features (Priac$m a$-type aedeagus in Recent Priacma and fossil Gracilicupes inherited from probable ancestor of the Holometabola) and therefore early divergence of the order Coleoptera can preliminary defined as Tshekardocoleidea $+\{$ Schizophorimorpha $+[$ Cupedinae $+($ Ommatinae + other families of Cupedomorpha)]\}; 
- The differences between subfamilies of the Cupedidae are not so great and some genera proposed in composition of Triadocupedinae should be considered in composition of Cupedinae [Kirghizocupes (=Mesocupoides syn.n.), ? Asimma and ? Pterocupes];

- Cupedinae is regarded as a separate subfamily which is not possible to divide into the tribes and, therefore, the tribes formerly proposed (Priacmini and Mesocupedini) are regarded as not reasonable taxa;

- The cupedines demonstrate a great stability in structure and sculpture of elytra and body appendages (antennae, mouth parts and legs), but some variability is exposed mostly in the proportions of body sclerites, structure of thorax and epicranium;

- Most fossil taxa described before this publication could not be put in Cupedinae or Ommatinae, frequently even cannot be recognized among other generic taxa because of not relable available characters or partly confusing original descriptions;

- Recent cupedines represent remains of a small part of ancient diversity (Mesozoic and Paleogene) and seem to consist of two group of the closely related (one of them is Priacma and second is all other taxa);

- In order to reach more or less equal hiati between Recent taxa and make them somehow comparable with extinct taxa, the taxa Adinolepis and Ascioplaga are regarded as subgenera of the same genus (Adinolepis) and for Paracupes ascius was proposed a new subgenus (Paracupoides subgen. $\mathrm{n}$.).

2. Distributional aspects:

- Cupedinae have been recorded in deposits of the Middle/late Triassic from Middle Asia: [Kirghizocupes (=Mesocupoides syn.n.), Asim$m a$ and Pterocupes), Europe (Helopides, Metacupes, Nannocurculionites, Parabuprestites, Paracurculionites and Pseudosilphites] and Australia (Mesothoris), although position of some Triassic forms needs to be confirmed by further studies;

- Portions of cupedines in Mesozoic (beginning from Middle/late Triassic) and Paleogene (not later than Eocene) outcrops are decreasing in later deposits; in the Neogene outcrops cu- pedines became rare and only 31 species have been found in the modern fauna diffusely spread in different continents, although in the Recent European and Antarctic faunas the cupedines are not known;

- Cenozoic extinct faunas in Europe represent considerable species and generic diversity of Cupedinae during the Paleogene (Menat, Messel, Eckfeld, Baltic amber), however later they became rather rare in deposits and reached only the Pliocene (Cupes praeglacialis).

3. Ecological aspects:

- Maintenance of many structural characters in all Recent species in the state not changed from the Middle/late Triassic ones testifies an extremely stable preference of habitats and extraordinal conservatism mode of life (probably since of time of formation of this subfamily);

- such stability can be maintained only under immutable conditions of life of the cupedines during the whole time of existence of this subfamily. These conditions could be provided by the larval development in interstices of tree trunks and comparatively short imaginal life;

- Diet of cupedines seems to have dependence on the structure of wood tissues, also on the fungal and microbial compositions associated with wood but not on systematic position of plants producing wood (gymposperms or angisperms).

\section{Acknowledgements}

The authors have a pleasure to receive generous assistance from many colleagues. Many thanks to Clotilde Berger-Pompili and Leygnac Mathilde, directors of the EHPAD du Pays de Menat, for their kind help and authorisations to collect fossil insects in a small but rich outcrop near the village of Menat (Puy-de-Dôme, France). Very special thanks to JeanMarc Pouillon who helped in the field to collect material. Particular thanks are expressed to A.G. Ponomarenko (PIN), who provided the authors with many consultations and advices in study the specimens examined. S. Wedmann (SFNFM), H. Lutz (LNNR), C. Gröhn (GPIM), W. Weitschat (GPIM), Chr. and H.W. Hoffeins (Hamburg), G. Herrling (Engter), T. Hörnschemeyer(GZUG), and F. Kernegger (Hamburg) essentially promoted the studies by assistance in acquisition of specimens examined or 
photographs of them. The authors also sincerely thank S. Pont (Laboratoire de Minéralogie et de Cosmochimie, MNHN) who helped the authors in the study of the fossils by electronic microscopy. T. Deuve, O. Montreuil, and A. Mantilleri (UMR 7205, Entomologie, MNHN) helped in management of the specimens from the collection of the modern beetles in MNHN and M.V.L. Barclay in BMNH. An essential help in preparation of the manuscript was obtained from S.I. Golovatch (Institute for Problems of Ecology and Evolution, Moscow) who checked English in its most important part and provided the authors with many valuable linguistic consultations. Bo Wang (Institute of Geology and Palaeontology of Chinese Academy of Sciences, Nanjing) and Mingyi Tian (South China Agricultural University, Guangdong) helped in translation and transliteration of Chinese papers. A.A. Prokin (Papanin Institute for Biology of Inland Waters of Russian Academy of Sciences, Borok, Yaroslavl Oblast) and Huali Chang $(\mathrm{CNU})$ assisted the authors to prepare photographs of the specimens examined from the collection of CNU. D.Ye. Shcherbakov (PIN) made some photographs and assisted in studies of the specimens from the collection of PIN. A.V. Kovalev (ZIN) helped in preparation of photographs of the specimens from the collection of ZIN and discussed with authors different aspects of studies and preparation of this paper. R.E. Nelson (Department of Geology, Colby College, Waterville, Maine, USA) facilitated to find contacts with S. Lubkin who allowed the authors to use her pictures from Lubkin (2003). S.A. Belokobylskij (ZIN), S.Yu. Sinev (ZIN) and I.V. Shamshev (ZIN) provided the authors with valuable consultations on the structure of male genitalia of different groups of Holometabola. The studies of the first author were partly carried out under the framework of the Russian state research project no. 01201351189, programme 'Research in Paris' of the City of Paris (Mairie de Paris), programme of the Presidium of the Russian Academy of Sciences "Problems of the origin of life and formation of the biosphere", Sorbonne Universités (Programme d'Accueil de Chercheurs de Haut niveau) and the Russian Foundation of Basic Research (grant 15-0402971-a). The authors greatly appreciate useful comments on an earlier version of the manuscript received from anonymous reviewers.

\section{References}

Aspöck U. 2002. Male genital sclerites of Neuropterida: an attempt at homologisation (Insecta: Holometabola) // Zool. Anzeiger. Bd.241. H.2. P.161-171. <DOI: 10.1078/0044-5231-00028>
Atkins M.D. 1958a. On the phylogeny and biogeography of the family Cupedidae (Coleoptera) // Canad. Entomol. Vol.90. Iss.4. P.532-537.

Atkins M.D. 1958b. Observations on the flight, wing movement and wing structure of male Priacma serrata (Lec.) (Coleoptera: Cupedidae) // Canad. Entomol. Vol.90. Iss.3. P.339-347.

Atkins M.D. 1963. The Cupedidae of the World // Canad. Entomol. Vol.95. Iss.2. P.140-162.

Beutel R.G., Ge S.-Q., Hörnschemeyer T. 2008. On the head morphology of Tetraphalerus, the phylogeny of Archostemata and the basal branching events in Coleoptera // Cladistics. Vol.24. Iss.3. P.270-298. <DOI: 10.1111/j.1096-0031.2007.00186.x>

Bouchard P., Bousquet Y., Davies A.E., Alonso-Zarazaga M.A., Lawrence J.F., Lyal C.H.C., Newton A.F., Reid C.A.M., Schmitt M., Ślipínski S.A., Smith A.B.T. 2011. Family-group names in Coleoptera (Insecta) // ZooKeys. Vol.88. 972 p. <DOI: 10.3897/zookeys.88.807>

Boulange H. 1924. Recherches sur l'appareil copulateur des Hyménoptères et specialement des Chalastogaster (Hymenoptera) // Mém. trav. Facult. catholiques Lille. Fasc.28. 444 p.

Böving A.G., Craighead F.C. 1930 (1931). An illustrated synopsis of the principal larval forms of the order Coleoptera // Entomol. Amerc. Vol.11. 351 p.

Brodie P.B. 1845. A history of the fossil insects in the Secondary rocks of England, accompanied by a particular account of the strata in which they occur, and of the circumstances connected with their preservation. London: John Van Voorst. xviii +130 p.

Buckland W. 1837. Geology and mineralogy considered with reference to natural theology. London. 2 vols. 619 p. +129 p. (insects in Vol.1. P.16, P.619+ Vol.2. P.7, P.111).

Carpenter F.M. 1992. Superclass Hexapoda // R.C. Moore, R.L. Kaesler (eds.). Treatise on Invertebrate Paleontology. Geol. Soc. Amer. and Univ. Kansas. Boulder, Colorado. Ser.R. Arthropoda 4. Vol.3-4. P.279-337.

Castro L.R., Dowton M. 2007. Mitochondrial genomes in the Hymenoptera and their utility as phylogenetic markers // Syst. Entomol. Vol.32. Iss.1. P.60-69.

Cobos A. 1961. Sobre la posicion sistematica del genero Potergus Bonvouloir y revision de las categorias supragenericas de la familia Throscidae (Coleoptera) // Mededeling. Koninkl. Belg. Inst. Natuurwetensch. Deel 37. No.35. P.1-6.

Comstock J.H. 1918. The wings of insects. Ithaca, N. Y.: Comstock Publishing Co. xviii +430 p.

Costa C., Vanin S.A., Ide S. 1999. Systematics and bionomics of Cneoglossidae, with a cladistic analysis of Byrrhoidea sensu Lawrence \& Newton (1995) (Coleoptera, Elateriformia) // Arquivos Zoolog., São Paulo. Vol.55. Iss. 3. P.231-300.

Costa C., Vanin S.A., Lawrence J.F., Ide S. 2003. Systematics and cladistic analysis of Cerophytidae (Elateroidea: Coleoptera) // Syst. Entomol. Vol.28. Iss. 3. P.375-408.

Costa C, Vanin S.A., Rosa S. 2014. Description of a new genus and species of Cerophytidae (Coleoptera: Elat- 
eroidea) from Africa with a cladistic analysis of the family // Zootaxa. Vol.3878. No.3. P.248-260. <DOI: org/10.11646/zootaxa.3878.3.2>

Crowson R.A. 1962. Observations on the beetle family Cupedidae, with description of two fossil forms and key to recent genera // Ann. Mag. Nat. Hist. Ser.13. Vol.5. P.147-157.

Crowson R.A. 1975. The evolutionary history of Coleoptera, as documented by fossil and comparative evidence // Atti del X Congresso Nazionale Italiano di Entomologia, Sassari. Maggio 1974, Firenze. P.47-90.

Crowson R.A. 1976. The systematic position and applications of Crowsoniella // Boll. Museo civ. Storia natur. Verona. 1975. Fasc.2. P.459-463.

Crowson R.A. 1981. The biology of Coleoptera. London: Academic Press. xii +802 pp.

Dubois A., Crochet P.-A., Dickinson E.C., Nemésio A., Aescht E., Bauer A.M., Blagoderov V., Bour R., De Carvalho M.R., Desutter-Grandcolas L., Frétey T., Jäger P., Koyamba V., Lavilia E.O., Löbl I., Louchart A., Malécot V., Schatz H., Ohler A. 2013. Nomenclatural and taxonomic problems related to the electronic publication of new nomina and nomenclatural acts in zoology, with brief comments on optical discs and on the situation in botany // Zootaxa. Vol.3735. 94 p. $<$ DOI: org/10.11646/zootaxa.3735.1.1>

Dunstan B. 1923. Mesozoic insects of Queensland. 1. Introduction and Coleoptera // Publ. Geol. Survey Queensland. Vol.273. 74 p..

Edwards J.G. 1953a. The morphology of the male terminalia of beetles belonging to the genus Priacma (Cupesidae) // Bull. l'Inst. R. Sci. Natur. Belgique. T.29. No.1. P.1-8.

Edwards J.G. 1953b. The peculiar clasping mechanisms of the phallus of males of Priacma (Cupesidae, or Cupedidae) // Coleopterist's Bull. Vol.7. Iss.1. P.17-20.

Emel'yanov A.F. 2000. [Some macroevolutionary modes connected with recurrent and new application of once acquired structures] // Teoreticheskie problemy ekologii i evolyutsii (Tret'i Lyubishchevskie chteniya), Togliatti: Inst. Volga Bassin of Russ. Acad. Sci. P.6064 [in Russian].

Fedorenko D.N. 2009. Evolution of the beetle hind wing, with special reference to folding (Insecta, Coleoptera). Sofia-Moscow: Pensoft. 335 pp.

Fedorenko D.N., Ponomarenko A.G. 2012. First records of hindwings of Permian beetles (Coleoptera) // Paleont. J. Vol.46. P.164-170.

Forbes W.T.M. 1922. The wing venation of the Coleoptera // Ann. Entomol. Soc. Amer. Vol.15. Iss.4. P.328345.

Forbes W.T.M. 1926. The wing folding patterns of the Coleoptera // J. N. Y. Entomol. Soc. Vol.34. No.1. P.42-68; No.2. P.91-139 (incl. pls. 7-18).

Forbes W.T.M. 1928. The Protocoleoptera // Psyche. Vol.35. Iss.1. P.32-35.

Fritel P.H. 1903. Histoire Naturelle de la France, Paléobotanique. Paris: Les Fils d'Emile Deyrolle. T.24. 347 p.

Ganglbauer L. 1903. Systematisch-koleopterologische Studien// Münch. Koleopterol. Zeitschr. Bd.1. Liefg.3. S.271-319.
Gardiner B.G. 1961. New Rhaetic and Liassic Beetles // Palaeontology. Vol.4. No.1. P.87-89.

Ge S.-Q., Yang X.-K. 2004. Two new Chinese species of Tenomerga Neboiss (Coleoptera: Cupedidae), with a world catalog of the genus // Proc. Entomol. Soc. Washington. Vol.106. Iss. 3. P.631-638.

Geertsema H., Heever J.A., van den. 1996. A new beetle, Afrocupes firmae gen. et sp. nov. (Permocupedidae), from the late Palaeozoic Whitehill Formation of South Africa // S. Afr. J. Sci. Vol.92. Iss.10. P.497-499.

Gersdorf E. 1976. Dritter Beiträg über Käfer (Coleoptera) aus dem Jungtertiär von Willershausen, B1. Northeim 4226//Geolog. Jahrb., Hannover. Ser.A. Bd.36. S.103145.

Giebel C.G. 1856. Die Insekten und Spinnen. Fauna der Vorwelt mit steter Breucksichtigung der lebenden Thiere. Leipzig: F.A. Brodhaus. Bd.2. Abt.1. xviii + $511 \mathrm{~S}$.

Haug J.T., Labandeira C.C., Santiago-Blay J., Haug C., Brown S. 2015. Life Habits, Hox Genes, and Affinities of a 311 Million-Year-Old Holometabolan Larva // BMS Evol. Biology. Vol.15. Iss.208. <DOI: 10.11862-015-0428-8>

Haupt H. 1950. Die Käfer (Coleoptera) aus der eozänen Braunkohle des Geiseltales // Geologica. Bd.6. 168 S.

Hájek J. 2007. Revision of the genus Eulichas Jacobson, 1913 (Coleoptera: Eulichadidae) I. Introduction, morphology of adults, key to subgenera and species groups, and taxonomy of E. funebris species group // Zootaxa. Vol.1620. P.1-35.

Handlirsch A. 1906-1908. Die fossilen Insekten und die Phylogenie der rezenten Formen. Ein Handbuch für Paläontologen und Zoologen. Leipzig: V.W. Engelman. 1430 S. [published in parts between 1906 and 1908 as follows: i-vi, S. 1-160, pls. 1-9 (May 1906); S. 161-320, pls. 10-18 (June 1906); S. 321-480, pls. 19-27 (August 1906); S. 481-640, pls. 28-36 (October 1906); S. 641-800, pls. 37-45 (February 1907); S. 801-960, pls. 46-51 (June 1907); S. 961-1120 (November 1907); S. 1121-1280 (January 1908); S. viiix, 1281-1430 (July 1908)].

Heer O. 1865. Die Urwelt der Schweiz. Zurich: F. Schulthess Verlag. $622 \mathrm{~S}$.

Heer O. 1878. Über einige Insektenreste aus der raetischen Formation Schonens // Geol. För. Stockholm Förhandl. Bd.4. S.192-197.

Hennig W. 1981. Insect phylogeny. Chichester, N. Y.: J. Wiley and Sons, Inc. 514 p.

Hieke F., Pietrzeniuk E. 1984. Die Bernstein-Käfer des Museums für Naturkunde, Berlin (Insecta: Coleoptera) // Mitt. Zool. Mus. Berlin. Bd.60. H.2. S.297-326.

Hong Y.C. 1976. [Insecta] // [Paleontological Atlas of the North China Region: Inner Mongolia]. Vol.2. P.8187 [in Chinese].

Hong Y.C. 1980. [Fossil insects] // [Mesozoic Stratigraphy and Paleontology of Shaanxi-Gansu-Ningxia Basin] Vol.2. P.111-114 [in Chinese].

Hong Y.C. 1982. [Mesozoic Fossil Insects of Jiuquan Basin in Gansu Province]. Bejing: Geological Publishing House. 187 p. [in Chinese] 
Hong Y.C. 1983. [Middle Jurassic Fossil Insects in North China]. Beijing: Geological Publishing House. 223 p. [in Chinese]

Hong Y.C. 1992. [Taxonomic names, in a new Middle Jurassic insect genus - Hebeicoleus gen. nov. (Insecta: Coleoptera) of Chengde, Hebei Province] // Mem. Beijing Nat. Hist. Mus. Vol.51. P.37-44 [in Chinese].

Hörnschemeyer T. 2009. A species level phylogeny of Archostemata (Coleoptera) - where do Micromalthus debilis and Crowsoniella relicta belong? // Syst. Entomol. Vol.34. Iss.3. P.533-558.

Hörnschemeyer T., Tröster G., Wedmann S. 1995. Die eozänen Käferfaunen des Geiseltales und der Grube Messel ein Vergleich unter systematischen und paläoökologischen Gesichtspunkten // Hallesches Jahrb. Geowissensch. Reihe B: Geol. Paläontol. Mineral. Bd.17. S.107-119.

Hörnschemeyer T., Beutel R.G., Pasop F. 2002. Head structures of Priacma serrata LeConte (Coleoptera: Archostemata) inferred from X-ray tomography // J. Morphol. Vol.252. ${ }^{1}$ 3. P.298-314.

Hörnschemeyer T., Goebbels J., Weidemann G., Faber C., Haase A. 2006. The head of Ascioplaga mimeta (Coleoptera: Archostemata) and the phylogeny of Archostemata // Europ. J. Entomol. Vol.103. Iss.2. P.409423.

Huber P., McDonald N.G., Olsen P.E. 2003. Early Jurassic insects from the Newark Supergroup, northeastern United States // P.M. LeTourneau, P.E. Olsen (eds.). The Great Rift Valleys of Pangea in Eastern North America. New York: Columbia Univ. Press. Vol.2: Sedimentology, Stratigraphy, and Paleontology. P.206-223.

Hünefeld F., Marvaldi A.E., Müller B., Lawrence J.F., Beutel R.G. 2011. The male postabdomen of the "ancestral" archostematan beetle Tetraphalerus bruchi Heller, 1913 (Ommatidae) and its phylogenetic significance // Arthropod Struct. and Developm. Vol.40. No.2. P.146-158.

Iablokoff-Khnzorian S.M. 1960. [New beetles from Baltic amber] // Paleontol. Zhurn. No.1. P.90-101 [in Russian].

Iablokoff-Khnzorian S.M. 1980. Le segment genital male de coléoptères et son importance phylogenetique (Coleoptera) // Deutsche Entomol. Zitschr., N.F. Bd.27. P.251-295.

Jarzembowski E.A., Yan E.V., Wang B., Zhang H. 2013a. Ommatin beetles (Insecta: Coleoptera) from the Lower Cretaceous of northeast China and southern England//Terr. Arthropod Rev. Vol.6. P.135-161.<DOI: 10.1163/18749836-06021062>

Jarzembowski E.A., Yan E.V., Bo Wang, Haichun Zhang. 2013b. Brochocolein beetles (Insecta: Coleoptera) from the Lower Cretaceous of northeast China and southern England // Cretac. Res. Vol.44. Iss.1. P.111. <DOI: 10.1016/j.cretres.2013.03.003>

Jell P.A. 2004. The fossil insects of Australia // Mem. Queensland Mus. Vol.50. 124 p.

Jin Z., Slipinski A.S., Pan H. 2013. Genera of Dascillinae (Coleoptera: Dascillidae) with a review of the Asian species of Dascillus Latreille, Pentalon Schonherr and Sinocaulus Fairmaire // Ann. Zool., Warszawa.
Vol.63. Iss.4. P.551-652. <DOI: 10.3161/ 000345413X676786>

Kasap H., Crowson R.A. 1975. A comparative anatomical study of Elateriformia and Dascilloidea // Trans. R. Entomol. Soc. London. Vol.126. Pt.4. P.441-495.

Kedves M., Russel D.E. 1982. Palynology of the Thanetian layers of Menat. The Geology of the Menat basin, France // Palaeontographica. Abt.B. Bd.182. P.87150.

Kimsey L.S., Wasbauer M.S. 2013. Revision of the brachycistidine genus Colocistis Krombein, 1942 (Hymenoptera, Tiphiidae) // J. Hymenopt. Res. Vol.33. P.1-24. <DOI: 10.3897/JHR.33.5078>

Kirejtshuk A.G. 1991. Evolution of mode of life as the basis for division of the beetles into groups of high taxonomic rank // M. Zunino, X. Belles, M. Blas (eds.). Advances in Coleopterology. Associacion Europea de Coleopterologia, Barcelona. P.249-261.

Kirejtshuk A.G. 2005. A revision of the genus Cupes Fabricius, 1801 from Baltic amber and some notes on taxonomy and composition of the family Cupedidae (Coleoptera, Archostemata) // Mitt. Geol.-Paläontol. Inst. Univ. Hamburg. Bd.89. P.55-84.

Kirejtshuk A.G. 2016. Genus Cupes Fabricius, $1801(\mathrm{Cu}-$ pedidae: Cupedinae: Cupedini): atlas of extinct beetle taxa. Updated March 2016 [updated at http:// www.zin.ru/animalia/coleoptera/eng/cupes_ak.htm]

Kirejtshuk A.G., Nel A., Collomb F.-M. 2010a. New Archostemata (Insecta, Coleoptera) from the French Paleocene and Early Eocene // Ann. Soc. Entomol. France (N.S.). Vol.46. Fasc.1-2. P.216-227. $<$ DOI:10.1080/00379271.2010.10697661>

Kirejtshuk A.G., Ponomarenko A.G., Prokin A.A., Chang H., Nikolajev G.V., Ren D. 2010b. Current knowledge of Mesozoic Coleoptera from Daohugou and Liaoning (Northeast China) // Acta Geol. Sinica, Engl. Edition. Vol.84. Iss.4. P.783-792. < DOI: 10.1111/ j.1755-6724.2010.00253.x>

Kirejtshuk A.G., Poschmann M., Prokop J., Garrouste R., Nel A. 2013. Evolution of the elytral venation and structural adaptations in the oldest Palaeozoic beetles (Insecta: Coleoptera: Tshekardocoleidae) // J. Syst. Palaeontol. Vol.12. Iss.5. P.575-600. <DOI:10.1080/ 14772019.2013.821530>

Kirejtshuk A.G., Nel A. 2013. Skleroptera, a new order of holometabolous insects (Insecta) from the Carboniferous // Zoosyst. Rossica. Vol.22. Iss.2. P.247-257.

Kirejtshuk A.G., Ponomarenko A.G. 2016. Catalogue of fossil Coleoptera. Beetles (Coleoptera) and Coleopterologists. Zoological Institute of the Russian Academy of Sciences, St. Petersburg. Updated March 2016 [updated at http://www.zin.ru/Animalia/Coleoptera/ eng/paleosys.htm].

Kristensen N.P. 1999. Phylogeny of endopterygote insects, the most successful lineage of living organisms // Europ. J. Entomol. Vol.96. Iss.3. P.237-253.

Kukalová J. 1969. On the systematic position of the supposed Permian beetles Tshecardocoleidae, with a description of a new collection from Moravia // Sborn. Geol. Ved, Paleontol. Sv. Vol.11. P.139-160. 
Kukalová-Peck J. 1991. Chapter 6: Fossil history and the evolution of hexapod structures // I.D. Naumann (ed.). The insects of Australia, a textbook for students and research workers. 2nd ed. Melbourne: Melbourne Univ. Press. Vol.1. P.141-179.

Kukalová-Peck J., Lawrence J.F. 1993. Evolution of the hind wing in Coleoptera // Canad. Entomol. Vol.125. Iss.2. P.181-258.

Kukalová-Peck J., Lawrence J.F. 2004. Relationships among coleopteran suborders and major endoneopteran lineages: evidence from hind wing characters // Europ. J. Entomol. Vol.101. Iss.1. P.95-144.

Kolbe H. 1908. Mein System der Coleopteren // Zeitschr. wiss. Insekten-Biol. Bd.4. S.116-123, 153-162, 219226, 246-251, 286-294, 389-400.

Labandeira C. 2011. Evidence for an earliest Late Carboniferous divergence time and the early larval ecology and diversification of major holometabola lineages // Entomol. Amer. Vol.117. Iss.1. P.9-21.

Lameere A.L. 1899. Discours sur la raison d'être des métamorphoses chez les insects // Bull. Ann. Soc. R. Belge d'Entomol. T.43. P.619-636.

Laurent L. 1912. Flore fossile des schistes de Menat (Puyde-Dome) // Ann. Mus. d'Hist. Natur. Marseille. T.14. $246 \mathrm{p}$.

Lawrence J.F. 1999. The Australian Ommatidae (Coleoptera: Archostemata): new species, larva and discussion of relationships // Invert. Taxon. Vol.13. Iss.3. P.369-390.

Lawrence J.F., Ślipiński A., Seago A.E., Thayer M.K., Newton A.F., Marvaldi A.E. 2011. Phylogeny of the Coleoptera based on morphological characters of adults and larvae // Ann. Zool., Warszawa. Vol.61. 217 p.

Lewis D.L., DeCamillis M., Bennett R.L. 2000. Distinct roles of the homeotic genes Ubx and abd-A in beetle embryonic abdominal appendage development // Proc. Nat. Acad. Sci. U.S.A. Vol.97. Iss.9. P.4504-4509. <DOI: 10.1073 /pnas.97.9.4504>

Lubkin S.H. 2003. Paracupes svitkoi (Coleoptera: Cupedidae), a new species from the Cretaceous of New Jersey // Acta Zool. Cracov. Vol.46 (suppl. - Fossil Insects). P.189-194.

McKenna D.D., Farrell B.D. 2010. 9-genes reinforce the phylogeny of Holometabola and yield Alternate Views on the Phylogenetic Placement of Strepsiptera // Plos One. 5 (7) e11887. P.1-8. <doi:10.1371/journal.pone. 0011887>

Martins-Neto R.G., Gallego O.F., Mancuso A. 2006a. The Triassic insect fauna from Argentina: Coleoptera from Los Rastros Formation (Bermejo Basin), La Rioja Province// Ameghiniana, Buenos Aires. Vol.43. Iss.3. P.591-609.

Martins-Neto R.G., Brauckmann C., Gallego O.F., Carmona M.J. 2006b. The Triassic insect fauna from Argentina. - Blattoptera, Glosselytrodea, Miomoptera, Auchenorrhyncha, and Coleoptera from the Los Rastros Formation (Bermejo Basin), Los Chañares locality (La Rioja Province) // Clausthaler Geowissensch. H.5. P.1-9.

Martynov A.V. 1926. [To the knowledge of fossil insects from Jurassic beds in Turkestan. 5. On some interest- ing Coleoptera] // Ezhegodnik Russk. Paleontol. Obshch. T.5. P.1-38 [in Russian and English].

Martynov A.V. 1931. [New Permian insects from Tikhie Gory. II. Neoptera (excluding Miomoptera)] // Trudy Geol. Muz. Akad. Nauk SSSR. T.8. P.149-212 [in Russian, with English summary].

Matsuda R. 1976. Morphology and evolution of the insect abdomen. Oxford: Pergamon Press. 534 p.

Merkl O. 1988. Novelties of Sivacrypticus Kaszab, 1964 and Enneboeus Waterhouse, 1878 (Coleoptera: Archeocrypticidae) // Ann. Hist.-Natur. Mus. Nat. Hungar. Vol.80. P.71-78.

Mickoleit G. 1973. Über den Ovipositor der Neuropteroidea und Coleoptera und seine phylogenetische Bedeutung (Insecta, Holometabola) // Zeitschr. Morphol. Tiere. Bd.74. H.1. S.37-64.

Muona J. 1993. The phylogeny, classification and biology of the family Eucnemidae (Coleoptera) // Entomol. Scand. (Suppl.) Vol.43. 133 p.

Nabozhenko M.V., Kirejtshuk A.G. 2014. Cryptohelops menaticus - a new genus and species of the tribeHelopini (Coleoptera: Tenebrionidae) from the Palaeocene of Menat (France) // C.R. Palevol. Vol.13. ${ }^{1} 2$. P.65-71.

Neboiss A. 1960. On the family Cupedidae (Coleoptera) // Proc. R. Soc. Victoria. Vol.72. P.12-20.

Neboiss A. 1984. Reclassification of Cupes Fabricius (sensu lato), with descriptions of new genera and species (Cupedidae, Coleoptera) // Syst. Entomol. Vol.9. Iss.4. P.443-477.

Neboiss A. 1989. New species of Archostemata (Coleoptera: Ommatidae, Cupedidae) // Rev. franç. entomol. (N.S.) Vol.11. P.109-115.

Nel A. 1989. Les Gyrinidae fossiles de France (Coleoptera) // Ann. Soc. Entomol. France (N.S.). Vol.25.Fasc.2. P.321-330.

Nel A. 2008. The oldest bee fly in the French Paleocene (Diptera: Bombyliidae) // C.R. Palevol. Vol.7. P.401405.

Nel A., Roques P., Nel P., Prokin A.A., Bourgoin T., Prokop J., Szwedo J., Azar D., Desutter-Grandcolas L., Wappler T., Garrouste R., Coty D., Huang D., Engel M.S., Kirejtshuk A.G. 2013. The earliest-known holometabolous insects // Nature, Res. Letters. Vol.503. P.257-261. <DOI:10.1038/nature12629> 15 pp. + Suppl. Information, $14 \mathrm{pp}$.

Perkovsky E.E. 2007. [On the find of adult Micromalthus (Coleoptera, Micromalthidae) in Dominican amber] // Paleontol. zhurn. No.6. P. 36-38 [in Russian, with English summary] [English translation: Paleontol. J. Vol.41. Iss.6. P.626-628].

Pesenko Yu.A. 1983. [Sweet bees (Halictidae), subfamily Halictinae, tribe Nomioidini (Fauna of Palaearctics)] // Fauna SSSR. New series No.129. Nasekomye pereponchatokrylye. Vol.17. Pt.1. Leningrad: Nauka Publ. 200 p. [in Russian].

Peters R.S., Meusemann K., Petersen M., Mayer C., Wilbrandt J., Ziesmann T., Donath A., Kjer K.M., Aspöck U., Aspöck H., Aberer A., Stamatakis A., Friedrich F., Hünefeld F., Niehuis O., Beutel R.G., Misof B. 2014. 
The evolutionary history of holometabolous insects inferred from transcriptome-based phylogeny and comprehensive morphological data // BMC Evol. Biol. Vol.14. Paper 52. 33 p. <DOI: 10.1186/1471-214814-52>

Pinto I.D. 1987. Permian insects from Paraná Basin, South Brazil. IV Coleoptera // Pesquisas. Vol.19. P.5-12.

Piton L. 1940. Paleontologie du gisement éocène de Menat (Puy-de-Dome), flore et faune. Mem. Soc. Hist. Natur. Auvergne, Clermont-Ferrand. T.1. 303 p.

Ponomarenko A.G. 1964. [New beetles of the family Cupedidae from the Jurassic deposits in Karatau] // Paleontol. zhurn. No.2. P.49-62 [in Russian].

Ponomarenko A.G. 1966a. [New beetles of the family Cupedidae (Coleoptera) from Mesozoic deposits of Transbaikalia] // Entomol. Obozr. T.45. P.138-143 [in Russian, with English summary] [English translation: Entomol. Review. Vol.45. Iss.1. P.75-79].

Ponomarenko A.G. 1966b. [Beetles of the family Cupedidae from the Lower Liassic of Soviet Central Asia] // Paleontol. Zhurn. No.4. P.47-68 [in Russian, with English summary] [English translation: Int. Geol. Review. 1967. Vol.9. P.957-973].

Ponomarenko A.G. 1968. [Archostematan beetles from the Jurassic of Karatau (Coleoptera, Archostemata)] // B.B. Rohdendorf (ed.). Yurskie nasekomye karatau [Jurassic insects of Karatau]. Moscow: AN SSSR. P.118-138 [in Russian].

Ponomarenko A.G. 1969. [Historical development of the Coleoptera - Archostemata] // Trudy Paleontol. Inst. AN SSSR. T.125. 240 p. [in Russian]

Ponomarenko A.G. 1973a. Erster Fund eines Cupediden im Neogen Europas (Coleoptera, Cupedidae) // Vìstn. Èeskoslov. Spoleèn. Zool. Vol.37. S.101-103.

Ponomarenko A.G. 1973b. [On division of the order Coleoptera into suborders.] // E.P. Narchuk (ed.). Voprosy paleontologii nasekomykh [Problems of the Insect Palaeontology.] Doklady na 24 Ezhegodnom Chteniya pamyati Nikolaya Aleksandrovicha Kholodkovskogo. Leningrad: Nauka Publ. P.78-89 [in Russian]

Ponomarenko A.G. 1986. [Beetles Scarabaeida (=Coleoptera)] // Nasekomye v rannemelovykh ekosistemakh zapadnoy Mongolii [Insects in Early Cretaceous ecosystems of the West Mongolia]. Sovmestnaya Sovetsko-Mongol'skaya Paleontologicheskaya Ekspeditsia [The Joint Soviet-Mongolian Palaeontological Expedition]. T.28. P.84-105 [in Russian].

Ponomarenko A.G. 1988. [Main trends in evolution of larvae and systematics of Oligoneoptera] // V.G. Dolin (ed.). 12 mezhdunarodnyi simpozium po entomofaune Srednei Evropy, Kiev, 25-30 Sentyabrya 1988. Tezisy dokladov. Kiev: Naukova Dumka. P.38-43 [in Russian].

Ponomarenko A.G. 1994. [New beetles of the family Cupedidae (Brochocoleini and Notocupedini) from the Mesozoic of Mongolia] // Paleontol. zhurn. No.3. P.83-93 [in Russian, with English summary]. [English translation:. Paleontol. J. Vol.28. Iss.2. P.102115].
Ponomarenko A.G. 1995. The geological history of beetles // J. Pakaluk, S.A. Slipinski (eds.). Biology, Phylogeny and Classification of Coleoptera. Papers Celebrating the 80th Birthday of Roy A. Crowson. Warszawa. Muzeum i Instytut Zoologii PAN Warszawa. 2 vol. P.155-171.

Ponomarenko A.G. 1997. [New beetles of the family Cupedidae from the Mesozoic of Mongolia. (Ommatini, Mesocupedini, Priacmini)] // Paleontol. zhurn. No.3. P.45-55 [in Russian, with English summary]. [English translation: Paleontol. J. Vol.31. Iss.3. P.389399].

Ponomarenko A.G. 2000. Beetles of the family Cupedidae from the Lower Cretaceous locality of Semen, Transbaikalia // Paleontol. J. Vol.34. Suppl.3. P.S317S322.

Ponomarenko A.G. 2002. Superorder Scarabaeidea Laicharting, 1781. Order Coleoptera Linné 1758 // A.P. Rasnitsyn, D.L.J. Quicke (eds.). History of insects. Dordrecht, Boston, London: Kluwer Academic Publishers. P.164-176.

Ponomarenko A.G. 2003. Ecological evolution of beetles (Insecta: Coleoptera)// Acta Zool. Cracoviensia. Vol.46 (suppl. - Fossil Insects). P.319-328.

Ponomarenko A.G. 2004. Beetles (Insecta, Coleoptera) of the Late Permian and Early Triassic // Paleontol. J. Vol.38. Suppl.2). P.S185-S196.

Ponomarenko A.G. 2006. [On the types of Mesozoic archostematan beetles (Insecta, Coleoptera, Archostemata) in the Natural History Museum, London] // Paleontol. zhurn. No.1. P.86-94 [in Russian, with English summary]. [English translation: Paleontol. J. Vol.40. Iss.1. P.90-99].

Ponomarenko A.G. 2013. New beetles (Insecta, Coleoptera) from the latter half of the Permian European Russia // Paleontol. J. Vol.47. P. 705-735.

Ponomarenko A.G. 2015. New beetles (Insecta, Coleoptera) from the Nedubrovo locality, terminal Permian or basal Triassic of European Russia// Paleontol. J. Vol.49. Iss.1. P.39-50. <DOI:10.1134/S0031030115010098>

Ponomarenko A.G., Mostovski M.B. 2005. New beetles (Insecta: Coleoptera) from the Late Permian of South Africa // Afr. Invertebr. Vol.46. P.253-260.

Ponomarenko A.G. 2016. Paleontological discoveries of beetles. Beetles (Coleoptera) and Coleopterologists. Zoological Institute of the Russian Academy of Sciences, St. Petersburg. Updated March 2016 [updated at http://www.zin.ru/animalia/Coleoptera/eng/ syst4.htm].

Ponomarenko A.G., Kirejtshuk A.G. in press (?2016). Suborder Archostemata Kolbe, 1908 // A.G. Kirejtshuk, A.G. Ponomarenko, A.S. Kurochkin, A.V. Alexeev, V.G. Gratshev, A.Yu. Solodovnikov, F.-T. Krell, C. Soriano. The beetle (Coleoptera) fauna of the insect limestone (Late Eocene), Isle of Wight, South England. Earth and Environmental Science. Trans. R. Soc. Edinburgh. Vol.00. P.000-000.

Prokin A.A., Kirejtshuk A.G., Ponomarenko A.G. 2015. On some Permian and Triassic larvae of Holometabola: beetles or not? // (Abstracts of the Immature 
Beetles Meeting 2015, October 1-2, Prague, Czech Republic). Acta Entomol. Mus. Nat. Pragae. Vol.55. No.2. P.882-884.

Rasnitsyn A.P. 1980. [Subclass Scarabaeida Laicharting, 1781. Winged insects] // B.B. Rohdendorf, A.P. Rasnitsyn (eds.). Istoricheskoe razvitie klassa nasekomykh [Historical development of the class Insecta]. Trudy Paleontol. Inst. AN SSSR. Moscow. Vol.175. P.24-28 [in Russian].

Rasnitsyn A.P. 2002. 2.2.1.3. Cohors Scarabaeiformes Laicharting, 1781. The holometabolans (= Holometabola Burmeister 1835 = Endopterygota Sharp, 1899 =Oligoneoptera Martynov, 1938) // A.P. Rasnitsyn, D.L.J. Quicke (eds.). History of insects. Dordrecht, Boston, London: Kluwer Academic Publishers. P.157159.

Ren D. 1995. [Systematic palaeontology. Insecta] // D. Ren, L. Lu, Z. Guo, S. Ji (ed.). [Fauna and stratigraphy of Jurassic-Cretaceous in Beijing and the adjacent areas]. Beijing. Seismic Publishing House. P.1-20, 47-121, 181-197 [in Chinese].

Riek E.F. 1968. On the occurrence of fossil insects in the Mesozoic rocks of Western Australia // Rec. Austral. Mus. Vol.27. P.311-312.

Roemer F. 1876. Notiz über ein Vorkommen von fossilen Käfern (Coleopteren) im Rhät bei Hildesheim // Zeitschr. Deutsch. Geol. Ges. Bd.28. Pt.1. S.350-353.

Rohdendorf B.B. 1961. [Order Coleoptera, beetles] // B.B. Rohdendorf, E.E. Becker-Migdisova, O.M. Martynova, A.G. Sharov (eds.). Paleozoyskie nasekomye Kuznetskogo basseyna [Palaeozoic insects of the Kuznetsk basin]. Trudy Paleontol. Inst. AN SSSR. Moscow. T.85. P.393-469 [in Russian].

Ross D.A., Pothecary D.D. 1970. Notes on adults, eggs, and first-instar larvae of Priacma serrata (Cupedidae) // Canad. Entomol. Vol.102. Iss.3. P.346-348.

Savard J., Tautz D., Richards S., Weinstock G.M., Gibbs R.A., Werren J.H., Tettelin H., Lercher M.J. 2006. Phylogenomic analysis reveals bees and wasps (Hymenoptera) at the base of the radiation of holometabolous insects // Genome Research. Vol.16. Iss.11. P.1334-1338.

Sharp M.A., Muir F. 1912. The comparative anatomy of the male genitalia in Coleoptera // Trans. Entomol. Soc. London. Vol.60. P.477-642 + pls. 42-78.

Shcherbakov D.E., Makarkin V.N., Aristov D.S., Vasilenko D.V. 2009. Permian insects from the Russky Island, South Primorye // Russian Entomol. J. Vol.18. No.1. P.7-16.

Simon S., Narechania A., DeSalle R., Hadrys H. 2012. Insect phylogenomics: exploring the source of incongruence using new transcriptomic data // Genome Biol. Evol. Vol.4. Iss.12. P.1295-1309.

Simonsen T.E., Kitching I.J. 2014. Virtual dissections through micro-CT scanning: a method for non-destructive genitalia 'dissections' of valuable Lepidoptera material // System. Entomol. Vol.39. Iss.4. P.606618. <DOI:10.1111/syen.12067>

Sinclair B.J. 2000. Morphology and terminology of Diptera male terminalia // L. Papp, B. Darvas (eds.). Contribu- tion to a Manual of Palaearctic Diptera. Budapest: Science Herald. Vol.1. P.53-74.

Smith D.R., Shinohara A. 2011. Review of the Asian wood-boring genus Euxiphydria (Hymenoptera, Symphyta, Xiphydriidae) // J. Hymenoptera Res. Vol.23. P.1-22. <DOI: 10.3897/JHR.23.1548>

Snodgrass R.E. 1941. The male genitalia of Hymenoptera // Smithsonian Miscell. Collect. Vol.99. No.14. 86 p.

Soriano C., Delclós X. 2006. New cupedid beetles from the Lower Cretaceous of Spain and the palaeogeography of the family // Acta Palaeontol. Polon. Vol.51. Iss.1. P.185-200.

Tan J.-J., Ren D. 2006. New fossil Priacmini (Insecta: Coleoptera: Archostemata: Cupedidae) from the Jehol biota of China // J. Nat. Hist. Vol.40. No.47-48. P.2653-2661.

Tan J.-J., Ren D., Shih C.-K. 2006. First record of fossil Priacma (Coleoptera: Archostemata: Cupedidae) from the Jehol Biota of western Liaoning, China // Zootaxa. Vol.1326. P.55-68.

Tan J., Hiang D., Ren D. 2007. First record of Fossil Mesocupes from China (Coleoptera: Archostemata: Cupedidae)// Acta Geol. Sinica, Engl. Edition. Vol.81. P.688-696.

Tan J.-J., Ren D. 2009. [Mesozoic Archostematan fauna from China]. Beijing: Science Press. www.sciencep. com. 347 p. [in Chinese and English]

Tan J., Wang Y., Ren D., Yang X. 2012. New fossil species of ommatids (Coleoptera: Archostemata) from the Middle Mesozoic of China illuminating the phylogeny of Ommatidae // BMC Evol. Biology. Vol.12. Paper 113. 19 p. <DOI: 10.1186/1471-2148-12-113>

Tanner V.M. 1927. A preliminary study of the genitalia of female Coleoptera // Trans. Amer. Entomol. Soc. Vol.53. P.5-49, pls. 2-15.

Tichomirova A.L. 1991. [Ontogeny transformation as a mechanism of the insect evolution]. Moscow: Nauka Publ. 168 p. [in Russian]

Tillyard R.J. 1916. Descriptions of the fossil Insects; Mesozoic and Tertiary Insects of Queensland and New South Wales. Descriptions of the fossil Insects and stratigraphical features // Queensland Geol. Surv. Vol.253. P.11-70.

Tillyard R.J. 1924. Upper Permian Coleoptera and a new order from the Belmont Beds, New South Wales // Proc. Linn. Soc. New South Wales. Vol.49. P.429-435.

Tillyard R.J., Dunstan B. 1916. Mesozoic and Tertiary insects of Queensland and New South Wales. Descriptions of the fossil insects and stratigraphical features // Publications Geol. Surv. Queensland. No. 253. P.1-63.

Tröster G. 1993. Zwei neue mitteleuropäische Arten der Gattung Tenomerga Neboiss 1984 aus dem Mitteleozän der Grube Messel und des Eckfelder Maares (Coleoptera; Archostemmata; Cupedidae); Fossilfundstätte "Eckfelder Maar" (Mittel-Eozaen) - Nr. 26 // Mainzer Naturwiss. Archiv. Bd.31. S.169-176.

Volkov A.N. 2012. [Fossil beetles from the Babiy Kamen' locality (Permian-Triassic of the Kuzbass)] // Modern paleontology: classical and new methods - 2012. 
Eight All-Russian School - 2011, Moscow. P.49-54 [in Russian].

Vulcano M.A., Pereira F.S. 1975. Cupesidae (Coleoptera) // Arq. Inst. Biol. Sao Paulo. Vol.42. P.31-68.

Wappler T., Currano, E.D., Wilf P., Rust J., Labandeira C.C. 2009. No post-Cretaceous ecosystem depression in European forests? Rich insect-feeding damage on diverse middle Palaeocene plants, Menat, France // Proc. R. Soc. London. Ser.B. Vol.276. P.4271-4277.

Westwood J.O. 1854. Contribution to fossil entomology // Quart. J. Geol. Soc. London. Vol.10. Iss.1-2. P.378396.

Whalley P.E.S. 1985. The systematics and palaeogeography of the Lower Jurassic insects of Dorset, England // Bull. Brit. Mus. (Nat. Hist.). Geol. Vol.39. No.3. $189 \mathrm{p}$.

Wiegmann B.M., Kim J.-W. 2009. Holometabolous insects (Holometabolata) // S.B. Hedges, S. Kumar (eds.). The timetree of life. Oxford Univ. Press. P.260263.
Wolf-Schwenninger K., Schawaller W. 2007. 11.17 Coleoptera: beetles // D. Martill, G. Bechly, R. Loveridge. The Crato fossil beds of Brazil: Window into an ancient world. Cambridge: Cambridge Univ. Press. P.340-350.

Zeuner F.E. 1930. Über einige Käfer aus dem deutschen Keuper // Jahrb. Preuss. Geol. Landesanst. Berlin. Bd.51. S.462-467.

Zeuner F.E. 1960. A Triassic insect fauna from the Molteno beds of South Africa // 11th International Congress of Entomology, Vienna. Vol.1. P.304-306.

Zeuner F.E. 1962. Fossil Insects from the Lower Lias of Charmouth, Dorset // Bull. Brit. Mus. (Nat. Hist.). Geology. Vol.7. No.5. P.153-171.

Zhang H.C. 1997. [Early Cretaceous insects from the Dalazi Formation of the Zhixin basin, Jilin Province, China] // Palaeoworld. Vol.7. P.75-103 [in Chinese].

Zhang J.F. 1986. [Some fossil insects from the Jurassic of northern Hebei, China]// The Paleontology and Stratigraphy of Shandong. P.74-84 [in Chinese].

Responsible editor K.G. Mikhailov

\section{Appendix 1. Material studied}

\section{Fossil species}

\section{Subfamily Cupedinae}

- Apriacma clavata (Tan, Ren et Shih, 2006), comb.n. [Priacma] — holotype ("CNU-CLB2006001").

- (?) Apriacma latidentata (Tan, Ren et Shih, 2006), comb.n. [Priacma] — holotype ("CNUC-LB2005010").

- Apriacma renaria (Tan, Ren et Shih, 2006), comb.n. [Priacma] — holotype ("CNU-CLB2006002").

- Apriacma tuberculosa (Tan, Ren et Shih, 2006), comb.n. [Priacma] — holotype ("CNU-CLB2005011").

- Cupes distinctissimus sp.n. — holotype ("MNHN.F.A.51118").

- Cupes eckfeldensis (Troester, 1993), comb.n. (Tenomerga) — holotype (LNNR "1992/461").

- Cupes groehni Kirejtshuk, 2005 - holotype ("4420", "4071 ex. Coll. C. Gröhn”, GPIM) and 4 paratypes ("372", DEIM (coll. Chr. and H.W. Hoffeins); "4421", "4318 ex Coll. C. Gröhn", GPIM; "790", from coll. Herrling; "792", from coll. Herrling).

- Cupes hoffeinsorum Kirejtshuk, 2005 - holotype ("1036-2", DEIM (coll. Chr. and H.W. Hoffeins)).

- Cupes kerneggeri Kirejtshuk, 2005 - holotype ("1036-2", ZIN (coll. H. Kernegger)).

-Cupes komissari Kirejtshuk, 2005 - holotype ("III, B233”, "Cupes tesselatus (Motschulsky, 1856), Yu. Popov det. 1990", GZUG).

- Cupes manifestus Kirejtshuk, Nel et Colomb, 2010 - holotype ("MNT-06-902", MTM, print and counterprint) and 5 additional specimens ("MNHN.F.A.52770", print and counterprint; "MNHN.F.A.52771", print; “MNHN F.A. 57525”, print; “MNHN F.A. 57526”, print: “MNHN F.A. 57527 ", print).

- Cupes messelensis (Troester, 1993), comb.n. (Tenomerga) - holotype (SFNFM "MeI 2806"). 
- Cupes ponomarenkoi Kirejtshuk, Nel et Colomb, 2010 - holotype (“PA 6457”, MNHN).

- Cupes rohdendorfi Iablokoff-Khnzorian, 1960 - holotype ("PIN 364/105") and six additional specimens ("3/1999", ZIN (coll. H. Kernegger); "360", GPIM (coll. C. Gröhn); ("9992", DEIM (coll. Chr. and H.W. Hoffeins) (“999-2”, DEIM (coll. Chr. and H.W. Hoffeins); “GPIM22"; "792", from coll. Herrling).

- Cupes simillimus sp.n. - holotype ("MNHN.F.A5 1120").

- Cupes tesselatus (Motschoulsky, 1856) [Cupoides] — neotype ("1 4422", GPIM).

- Cupes weitschati Kirejtshuk, 2005 - holotype ("PA 6457”, MNHN).

- Cupidium abavum Ponomarenko, 1968 - holotype ("PIN 2384/398").

- Forcicupes raucus Tan et Ren, 2006 - holotype ("CNU-C-LB2006004", print and counterprint).

- Gracilicupes crassicruralis Tan, Ren et Shin, 2006 - holotype ("CNU-C-LB2005001").

- Gracilicupes tenuicruralis Tan, Ren et Shin, 2006 (=tenuocruralis: Tan \& Ren, 2009) holotype ("CNU-C-LB2005002").

- Kirghizocupes indistinctus (Ponomarenko, 1969), comb.n. - holotype ("PIN 2240/72", print and counterprint).

- Kirghizocupes proporeius (Ponomarenko, 1969), comb.n. — holotype ("PIN 2240/3", print and counterprint) and three specimens ("PIN 2240/82", "PIN 2240/104", "PIN 2069/1034").

- Kirghizocupes sp. — one specimen ("PIN 3064/6424", print and counterprint).

- Latocupes bellus Tan et Ren, 2006 - holotype (“CNU-C-LB2005013”).

- Latocupes collaris (Tan, Huang et Ren, 2006), comb.n. - ? holotype (? "NIGPAS 142147”, found in CNU without number).

- Latocupes fortis Tan et Ren, 2006 - holotype (“CNU-C-LB2005012”).

- Menatops orbiculatus (Kirejtshuk, Nel et Colomb, 2010), comb.n. — holotype ("MNT-05198"( MTM), print and counterprint).

- Menatops bartenevi sp.n. - holotype ("MNHN F.A. 57524", print and counterprint).

- Mesocupes (Anaglyphites) admotus (Ponomarenko, 1964), comb.n. - holotype ("PIN 2066/ 2293") and 11 possible additional specimens (M. (A.) pr. admotus comb.n.: "PIN 2066/2280", "PIN 2066/2279", "PIN 2066/2271", print and counterprint), "PIN 2384/412", "PIN 2465/976", “PIN 2554/438", "PIN 2465/968”, "PIN 2384/405”, "PIN 2239/1505”, “PIN 2066/2277”, "PIN 2239/804").

- Mesocupes (Anaglyphites) capitatus (Ponomarenko, 1966), comb.n. - holotype ("PIN 1989/2993") and 1 additional specimen - (!) counterprint of holotype ("PIN 1989/1869").

- Mesocupes (Anaglyphites) clavatus (Ponomarenko, 1964), comb.n. - holotype ("PIN 2066/ 2275", print and counterprint) and 9 additional specimens (M. (A.) pr. clavatus comb.n.: "PIN 2384/402", "PIN 2384/403", "PIN 2384/406", "PIN 2384/408", "PIN 161/167”, "PIN 2232/807”, “PIN 2232/808”, “PIN 2232/809”, "PIN 2066/2276”, “PIN 2066/2285”).

- Mesocupes (Anaglyphites) minimus (Ponomarenko, 1997), comb.n. - holotype ("PIN 3589/ 6052", print and counterprint ).

- Mesocupes (Anaglyphites) mongolicus (Ponomarenko, 1997), comb.n. - holotype ("PIN 3559/1608") and two paratypes ("PIN 3559/6055", "PIN 3790/277”).

- Mesocupes (Cainomerga) brevicornis sp.n. - holotype (“MNHN.F.A51119”, print and counterprint).

- Mesocupes (Cainomerga) fraternus sp.n. - holotype (“MNHN.F.A52773”).

- Mesocupes (Cainomerga) immaculatus (Piton, 1940), comb.n. - holotype ("MNHN R07012").

- Mesocupes (Cainomerga) palaeocenicus sp.n. — holotype ("MNHN.F.A51117").

- Mesocupes (Cainomerga) ponti sp.n. - holotype ("MNHN.F.A51116", print and counterprint). 
- Mesocupes (Cainomerga) sp.1 - 1 specimen ("MNHN.F.A.57518", print)

- Mesocupes (Cainomerga) spp. — 4 specimens ("MNHN.F.A.52769"; "MNHN.F.A.57519", print and counterprint; "MNHN.F.A.57520"; "MNHN.F.A.57521”, print).

- (?) Mesocupes (Cainomerga) sp.1 - 1 specimen ("MNHN.F.A.52768").

- (?) Mesocupes (Cainomerga) sp.2 - 1 specimen ("MNHN.F.A. 57522").

- (?) Mesocupes (Cainomerga) sp.3 - 1 specimen ("MNHN.F.A. 57523").

- Mesocupes (Mesocupes) primitivus Martynov, 1926 - neotype ("PIN 2452/682") and three additional specimens ("PIN 2452/196", "PIN 2066/2272”, "PIN 2066/2283").

- Mesocupes (Mesocupes) minor Ponomarenko, 1968 - holotype ("PIN 2239/812") and one additional specimen ("PIN 2239/810", print and counterprint).

- Mesocupes (Mesocupes) paulus (Ponomarenko, 1964), comb.n. - holotype ("PIN 1789/ 91") and two additional specimens (M. (T.) pr. paulus comb.n.: "PIN 2384/411", "2384/405").

- Mesocupes (Mesocupes) bidens Ponomarenko, 1964 - holotype ("PIN 2465/980").

- Mesocupes (Mesocupes) spinosus Ponomarenko, 1964 — holotype (“PIN 2066/2294”, print and counterprint).

- Priacmopsis adumbrata Ponomarenko, 1966 - holotype ("PIN 1989/3000", print and counterprint) and 1 additional specimen ("PIN 1989/3032", print and counterprint).

- Taxopsis motschulskyi (Kirejtshuk, 2005), comb.n. - holotype ("PIN 363/130") and one paratype (“3750”, GZUG).

- Genus incertus sp.1 - 1 specimen (MNHN “R 63906”).

- Genus incertus sp.2 - 1 specimen ("MNHN.F.A.52794").

- Genus incertus sp.3 - 1 specimen ("MNHN.F.A.52772").

- Genus incertus sp.4 - 2 specimens (“MNHN.F.A.57529”, “MNHN.F.A.57530”).

\section{Subfamily Ommatinae}

- Brochocoleus angustus Tan, Ren et Shih, 2007 - holotype (“CNU-C-LB2006009”).

- Brochocoleus sulcatus Tan, Ren et Shih, 2007 - holotype ("CNU-C-LB2006011.

- Cionocoleus cervicalis Tan, Ren et Shih, 2007 - holotype (“CNU-C-LB2006007”).

- Cionocoleus planiusculus Tan, Ren et Shih, 2007 - holotype (“CNU-C-LB2006008”).

- Lithocupes punctatus Ponomarenko, 1969 - holotype (“PIN 2240/326”).

- Notocupes alienus Tan et Ren, 2006 - holotype ("CNU-C-LB2005001").

- Notocupes eumerus (Tan, Ren et Shih, 2006) - holotype (“CNU-C-LB2005007”).

- Notocupes minusculus (Tan, Ren et Shih, 2006) — holotype ("CNU-C-LB2005005").

- Notocupes porrectus (Tan, Ren et Shih, 2006) - holotype ("CNU-C-LB2005006").

- Notocupes protensus (Tan, Ren et Shih, 2006) — holotype ("CNU-C-LB2005008”).

- Notocupes psilatus (Tan, Ren et Liu, 2005) - holotype (“CNU-C-LB2004001”).

- Notocupes rudis (Tan, Ren et Liu, 2005) - holotype (“CNU-C-LB2004004”).

- Notocupes sibiricus (Ponomarenko, 2000) - 1 additional specimen ("PIN 2385/192").

- Notocupes tylodes (Tan, Ren et Shih, 2006) — holotype (“CNU-C-LB2005003”).

- Notocupoides triassicus Ponomarenko, 1966 - holotype ("PIN 2070/617”, print and counterprint).

- Tetraphalerus curvinervis Tan, Ren et Shih, 2007 - holotype (“CNU-C-LB2006006”).

- Tetraphalerus latus Tan, Ren et Shih, 2007 - holotype (“CNU-C-LB2006005”).

- Tetraphalerus trachylaenus (Tan, Ren et Shih, 2006) — holotype (“CNU-C-LB2005009”).

\section{Subfamily Triadocupedidae}

- Cupesia serricornia Ponomarenko, 1969 - holotype ("PIN 2240/85").

- Triadocupes ferghanensis Ponomarenko, 1966 - holotype ("PIN 2240/85"). 
Family Cupedidae (subfamilia incerta)

- Cupedites minutissimus Ponomarenko, 1985 - holotype ("PIN 1256/33") and three additional specimens (C. pr. minutissimus: "PIN 1256/39", "PIN 1256/75", "PIN 1256/76").

- 'Priacma' corrupta Ponomarenko, 1986 - holotype ("PIN 3152/1302”).

- 'Priacma' oculata Ponomarenko, 1997 - holotype ("PIN 4271/182", print and counterprint).

- 'Priacma' longicapitis Ponomarenko, 1997 - holotype ("PIN 4271/182", print and counterprint).

\section{Recent species}

- Adinolepis (Adinolepis) mathesonae (Neboiss, 1960) - 1 specimen (MNHN, "Vic., Pascoe Vale, Melbourne, 25 Dec. 1960, H. Hellgerien").

- Adinolepis (Adinolepis) youanga (Neboiss, 1960) - 1 specimen (ZIN, "27.30S 152.58E, Austr., Indooroopilly, QLD, 17-21.12.1990, A. Kirejtshuk").

- Adinolepis (Ascioplaga) mimeta (Neboiss, 1984), comb.n. - holotype, male (MNHN, "Mt Koghi, 15.iii. 1978 (Delobel)"); 1 paratype, male ("For \& De La Thy, i.1960 (Chazeau \& Saile)").

- Cupes anguliscutis Kolbe, 1886 - 19 specimens (MNHN, ZIN), Southern China, Annam, Tonkin.

- Cupes concolor Westwood, 1835 - 13 specimens (MNHN, ZIN), from different localities of USA.

- Cupes capitatus Fabricius, $1801-25$ specimens (BMNH, MNHN, ZIN), different localities of USA.

- Cupes leucophaeus Newman, 1839 - 3 specimens (BMNH, MNHN), South Africa.

- Cupes mucidus Chevrolat, 1829 - type of C. mucidus (MNHN, "Cupes mucidus Chevr, Yc.R.a. Porte P.58, des. Philippines"), lectotype and one paralectotype of C. clathratus (ZIN, "Vladivostok, 13-15.vii.1868, Cupes cancellatus mihi") and more than 120 specimens (MNHN, ZIN), Russian Far East (Primorsky Kray), Japan, Philippines.

- Cupes varians Lea, 1902 [Distocupes] - 1 specimen, "Austral.".

- Paracupes (Paracupes) brasiliensis Kolbe, 1898 - 1 specimen (MNHN), "Brasil” and one specimen (MNHN) "Bahia".

- Priacma serrata LeConte, 1861 - about 100 specimens (males) (MNHN, ZIN), different localities of western states of USA.

- Prolixocupes lathriellei (Solier, 1849) - holotype (MNHN, "Illapel”, "Museum Paris, Chili, Cl. Gay, 1845", “TYPE”, “Cupes Latreillei, Santjago et Illapel”) and more than 30 specimens (MNHN) - Chili.

- Prolixocupes lobiceps (LeConte, 1874) - 4 specimens (BMNH, MNHN), California.

- Rhipsideigma adjuncta Neboiss, 1984 - holotype (MNHN, "Rhipsideigma adjuncta sp. n., det, Neboiss, 1983, Holotype, $\sigma^{7}$ ", “Andringitra Est, Anjavidilava, 2000 m, 18. xii .- 15 .i. 1971”, "l/FDSMP/" "Museum Paris, Madagascar Centre Mission C. N . R.S .I RCP no 225").

- Rhipsideigma anosibense Neboiss, 1984 - holotype (MNHN, "Rhipsideigma anosibense sp. n., det, Neboiss, 1988, holotype, O'", "Anosibe, d-te 3-67, Collection Dujardin-Delacour ", "Madagascar Nord, 1500-2500 m").

- Rhipsideigma cretaceotincta (Kolbe, 1887) — one specimen (BMNH, "Tanganyika, 31.iii.1955, ex Piphadenia sp., dead part living tree (Gardner).

- Rhipsideigma lugubris (Fairmaire, 1895) - 15 specimens (MNHN), Madagascar.

- Rhipsideigma raffrai (Fairmaire, 1884) - holotype (MNHN, $\circ$, "Cupes Raffrayi Fairmaire, Madagascar/Museum Paris/Madagascar/Collection Leon Fairmaire 1906” and about 40 specimens (BMNH, MNHN) - Madagascar. 